Pacific Northwest

National Laboratory

Operated by Battelle for the

U.S. Department of Energy

\section{Geochemical Data Package for the 2005 Hanford Integrated Disposal Facility Performance Assessment}

\author{
K. M. Krupka \\ R. J. Serne \\ D. I. Kaplan
}

September 2004

Prepared for the U.S. Department of Energy under Contract DE-AC06-76RL01830 


\title{
DISCLAIMER
}

This report was prepared as an account of work sponsored by an agency of the United States Government. Neither the United States Government nor any agency thereof, nor Battelle Memorial Institute, nor any of their employees, makes any warranty, express or implied, or assumes any legal liability or responsibility for the accuracy, completeness, or usefulness of any information, apparatus, product, or process disclosed, or represents that its use would not infringe privately owned rights. Reference herein to any specific commercial product, process, or service by trade name, trademark, manufacturer, or otherwise does not necessarily constitute or imply its endorsement, recommendation, or favoring by the United States Government or any agency thereof, or Battelle Memorial Institute. The views and opinions of authors expressed herein do not necessarily state or reflect those of the United States Government or any agency thereof.

\author{
PACIFIC NORTHWEST NATIONAL LABORATORY \\ operated by \\ BATTELLE \\ for the \\ UNITED STATES DEPARTMENT OF ENERGY \\ under Contract DE-AC06-76RL01830
}

Printed in the United States of America
Available to DOE and DOE contractors from the Office of Scientific and Technical Information,
P.O. Box 62, Oak Ridge, TN 37831-0062;
ph: (865) 576-8401
fax: (865) 576-5728
email: reports@adonis.osti.gov

\begin{abstract}
Available to the public from the National Technical Information Service, U.S. Department of Commerce, 5285 Port Royal Rd., Springfield, VA 22161 ph: (800) 553-6847 fax: (703) 605-6900

email: orders@ntis.fedworld.gov

online ordering: http://www.ntis.gov/ordering.htm
\end{abstract}




\title{
Geochemical Data Package
} for the 2005 Hanford Integrated Disposal Facility

\section{Performance Assessment}

\author{
K. M. Krupka \\ R. J. Serne \\ D. I. Kaplan ${ }^{(a)}$
}

September 2004

Prepared for

the U.S. Department of Energy

under Contract DE-AC06-76RL01830

Pacific Northwest National Laboratory

Richland, Washington 99352

(a) Westinghouse Savannah River Company Aiken, South Carolina 29808 


\section{Summary}

CH2M HILL Hanford Group, Inc. (CH2M HILL) is designing and assessing the performance of an integrated disposal facility (IDF) to receive low-level waste (LLW), mixed low-level waste (MLLW), immobilized low-activity waste (ILAW), and failed or decommissioned melters. The CH2M HILL project to assess the performance of this disposal facility is the Hanford IDF Performance Assessment (PA) activity. The goal of the Hanford IDF PA activity is to provide a reasonable expectation that the disposal of the waste is protective of the general public, groundwater resources, air resources, surfacewater resources, and inadvertent intruders. Achieving this goal will require predicting contaminant migration from the facilities. This migration is expected to occur primarily through the movement of water through the facilities and the consequent transport of dissolved contaminants through the vadose zone to groundwater, where contaminants may be reintroduced to receptors via drinking water wells or mixing in the Columbia River.

Pacific Northwest National Laboratory (PNNL) assists CH2M HILL in their performance assessment activities. One of PNNL's tasks is to provide estimates of the geochemical properties of the materials comprising the IDF, the disturbed region around the facility, and the physically undisturbed sediments below the facility (including the vadose zone sediments and the aquifer sediments in the upper unconfined aquifer). The geochemical properties are expressed as parameters that quantify the adsorption of contaminants and the solubility constraints that might apply for those contaminants that may exceed solubility limits. Solubility constraints are used for conditions in which the calculated total concentration of the radionuclide and its stable isotopes is believed to exceed the solubility of an assumed controlling phase predicted from available thermodynamic data. The common parameters used to quantify adsorption and solubility are the distribution coefficient $\left(\mathrm{K}_{\mathrm{d}}\right)$ and the thermodynamic solubility product $\left(\mathrm{K}_{\mathrm{sp}}\right)$, respectively. In this data package, we approximate the solubility of contaminants using a more simplified construct, called the empirical solubility concentration limit, a constant value. For the 2005 IDF PA, little site/waste form/engineered barrier solubility work has been done to identify the solubility-controlling solids. When the controlling solid cannot be identified but empirical solubility tests clearly indicate that some unidentified phase is controlling solution concentration, an empirical solubility concentration limit is used.

The $\mathrm{K}_{\mathrm{d}}$ values and empirical solubility concentration limits for each contaminant are direct inputs to subsurface flow and transport codes used to predict the performance of the IDF system. In addition to the best-estimate $\mathrm{K}_{\mathrm{d}}$ values, a reasonable conservative value and a range are provided. The data package does not list estimates for the range in empirical solubility concentration limits or their uncertainties; the data package does provide values for both the $\mathrm{K}_{\mathrm{d}}$ values and empirical solubility concentration limits for different spatial zones in and surrounding the IDF system and does supply time-varying $K_{d}$ values for cement solidified waste. The $\mathrm{K}_{\mathrm{d}}$ values and empirical solubility concentration limits presented for each contaminant were presented in an earlier version of this report prepared by Kaplan and Serne (2000) for the 2001 ILAW PA and have been updated to include applicable data from investigations completed since that report was issued and our understanding of the geochemistry specific to Hanford has improved.

A discussion is also included on the evolution of the $\mathrm{K}_{\mathrm{d}}$ values recommended from the original 1999 ILAW PA through the 2001 ILAW and 2003 Supplemental PAs to the current values to be used for the 
2005 IDF PA for the key contaminants of concern: $\mathrm{Cr}(\mathrm{VI})$, nitrate, ${ }^{129} \mathrm{I},{ }^{79} \mathrm{Se},{ }^{99} \mathrm{Tc}$, and U(VI). This discussion provides the rationale for why some $\mathrm{K}_{\mathrm{d}}$ values have changed with time.

\section{Reference}

Kaplan DI and RJ Serne. 2000. Geochemical Data Package for the Hanford Immobilized Low-Activity Tank Waste Performance Assessment (ILAW PA). PNNL 13037 Rev. 1, Pacific Northwest National Laboratory, Richland, WA. 


\section{Acknowledgments}

We wish to thank the following Hanford Site and external reviewers for their insightful reviews of this data package. The reviewers considered geochemical technical comments, systems performance assessment comments, and readability comments for both lay persons and waste management/regulators who must make policy decisions based on the long-term predictions that emanate from performance assessment activities.

- Fred Mann (CH2M HILL Hanford Group, Inc.)

- Marcus I. Wood (Fluor Hanford)

- Raymond J. Puigh (Fluor Federal Services)

- Patrick V. Brady (Sandia National Laboratories)

- Kirk J. Cantrell (PNNL)

We are also particularly grateful to Sheila Bennett and Joanne Stover (PNNL) for completing the editorial review and Rose Urbina (PNNL) for final word processing of our technical report. 


\section{Contents}

Summary

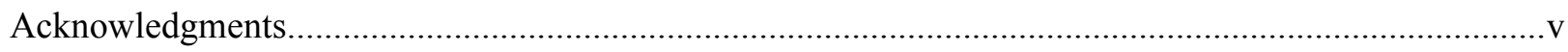

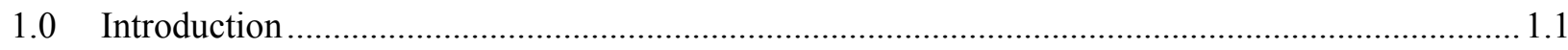

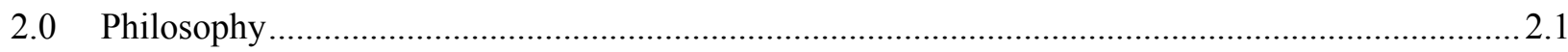

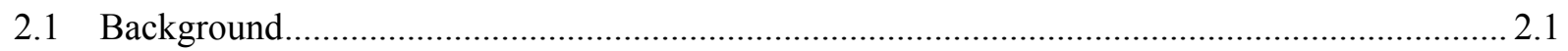

2.2 Relationship Between Distribution Coefficients and Retardation Factors .................................. 2.4

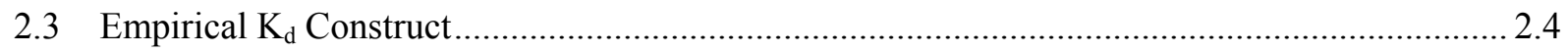

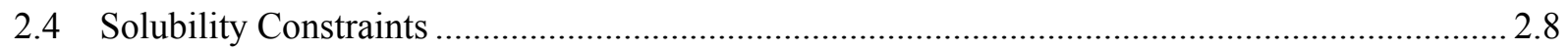

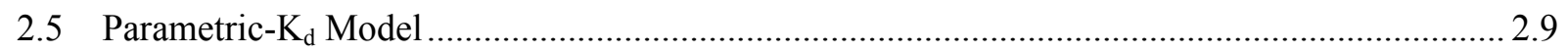

2.6 Overview of Mechanistic Adsorption Models....................................................................... 2.10

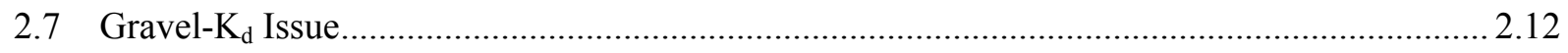

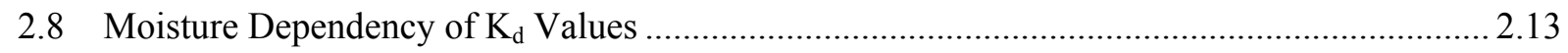

2.9 Colloid-Facilitated Transport of Contaminants …………………………………………..... 2.13

3.0 Geochemistry of Contaminants of Concern ………...................................................................... 3.1

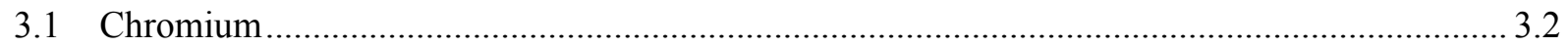

3.1.1 Oxidation States and Aqueous Speciation............................................................ 3.2

3.1.2 Precipitation and Coprecipitation ........................................................................ 3.4

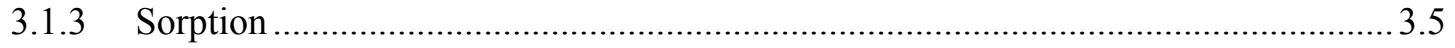

3.2 Iodine

3.2.1 Oxidation States and Aqueous Speciation.............................................................. 3.6

3.2.2 Precipitation and Coprecipitation............................................................................ 3.7

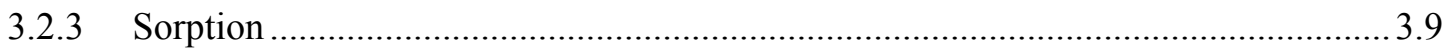

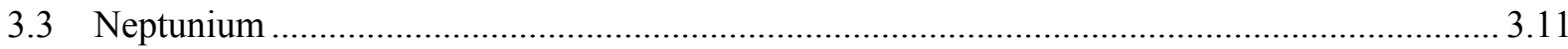

3.3.1 Oxidation States and Aqueous Speciation............................................................... 3.12

3.3.2 Precipitation and Coprecipitation ......................................................................... 3.13

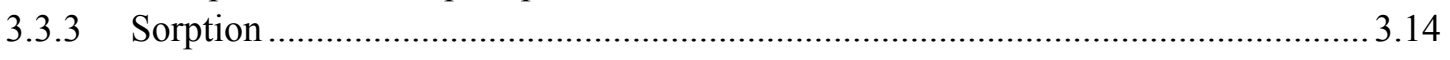

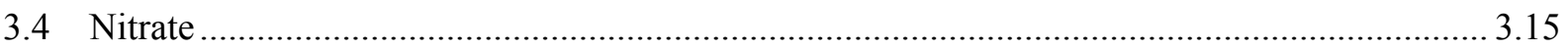

3.4.1 Oxidation States and Aqueous Speciation...............................................................

3.4.2 Precipitation and Coprecipitation...................................................................... 3.17 


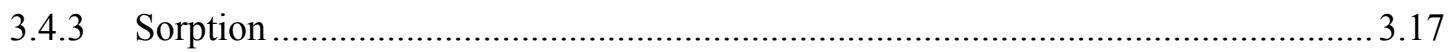

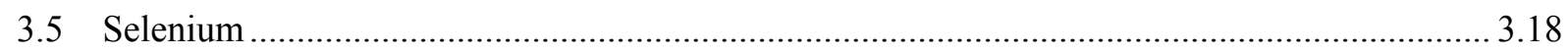

3.5.1 Oxidation States and Aqueous Speciation.............................................................. 3.18

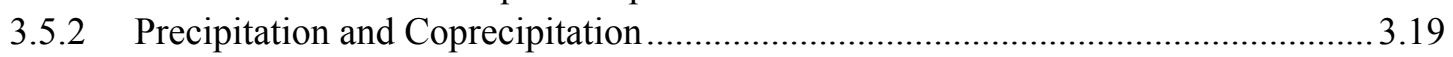

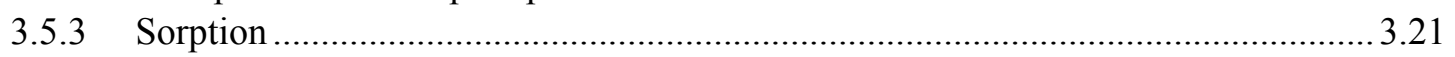

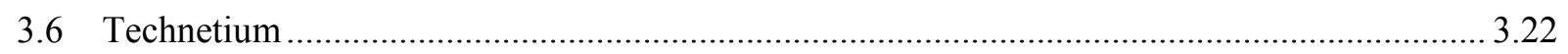

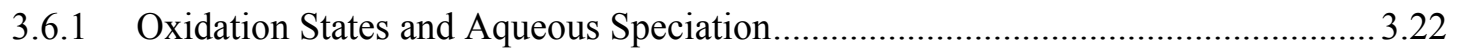

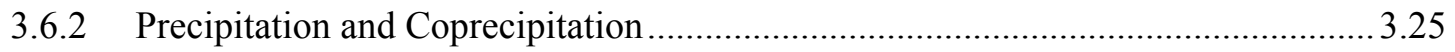

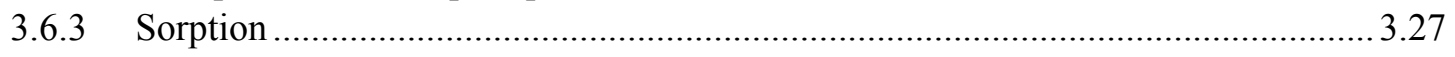

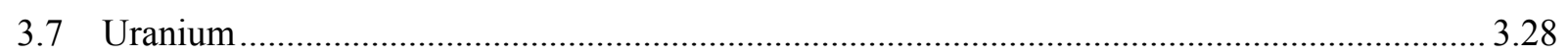

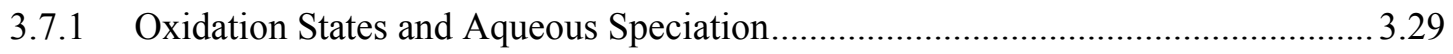

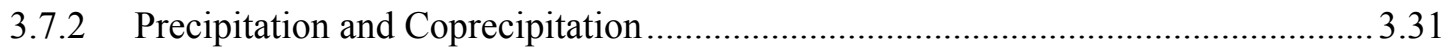

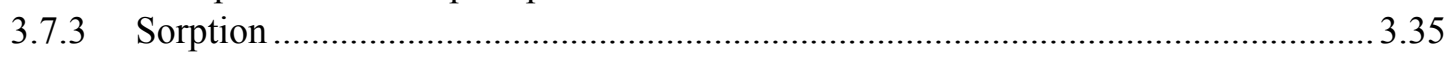

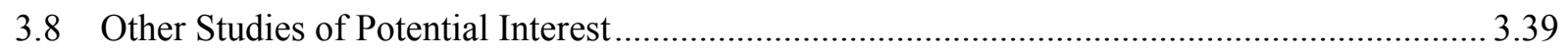

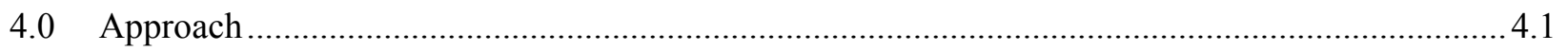

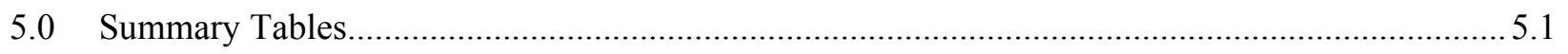

6.0 History of $\mathrm{K}_{\mathrm{d}}$ Values Selected for Key Contaminants of Concern ........................................... 6.1

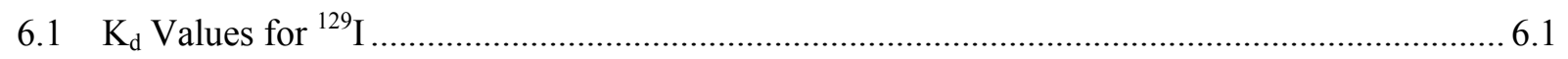

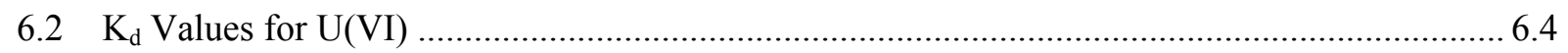

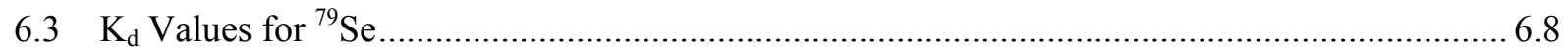

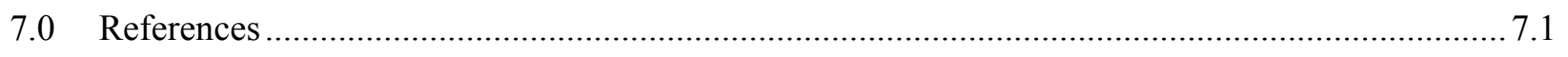

Appendix A - A Less Conservative Approach to Correcting $\mathrm{K}_{\mathrm{d}}$ Values for the Presence of Gravel....... A.1

Appendix B - Discussion on Double Layer and Film Thickness .......................................................

Appendix C - Information Requested for Near-Field Geochemical Transport Modeling.........................1 


\section{Figures}

3.1 Eh-pH Diagram Showing Dominant Aqueous Species of Chromium............................................. 3.3

3.2 Stability Diagram Showing Eh-pH Region that Calculates as Oversaturated with Respect

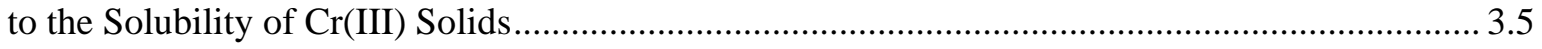

3.3 Eh-pH Diagram Showing Dominant Aqueous Species of Iodine................................................ 3.7

3.4 Eh-pH Diagram Showing Dominant Aqueous Species of Neptunium ........................................ 3.13

3.5 Stability Diagram Showing Eh-pH Region that Calculates as Oversaturated with Respect to the Solubility of Neptunium Solids ..................................................................................... 3.14

3.6 Eh-pH Diagram Showing Dominant Aqueous Species of Nitrogen .......................................... 3.16

3.7 Eh-pH Diagram Showing Dominant Aqueous Species of Selenium......................................... 3.18

3.8 Stability Showing Region that Calculates to be Oversaturated with Respect to the Solubility of Elemental Selenium

3.9 Eh-pH Diagram Showing Dominant Aqueous Species of Technetium ...................................... 3.23

3.10 Stability Diagram Showing Eh-pH Region that Calculates to be Oversaturated with Respect to the Solubility of Technetium Solids.......................................................................... 3.26

3.11 Eh-pH Diagram Showing Dominant Aqueous Species of Uranium.......................................... 3.30

3.12 Stability Diagram Showing Eh-pH Region that Calculates as Oversaturated with Respect to the Solubility of Uraninite $\left(\mathrm{UO}_{2}\right)$......

4.1 Schematic Representation of the Geochemical Zones for an IDF Cell (Cell 1) that Contains all Types of Wastes and Has a Pore Fluid Dominated by Cement Leachate in Portions of Vadose Zone.

4.2 Schematic Representation of the Geochemical Zones for an IDF Cell (Cell 1) that Contains all Types of Wastes and Has Pore Fluid Dominated by Natural Recharge and Wastes that Do Not Leach to any Significant Extent

4.3 Schematic Representation of the Geochemical Zones for an IDF Cell that Contains Only ILAW Glass or Glass-Dominated Cell 1 and Has Pore Fluid in Portions of Vadose Zone Dominated by Leachate from Glass Dissolution 


\section{Tables}

2.1 Summary of Chemical Processes Affecting the Mobility of Radionuclides and Contaminants (taken from EPA [1999a])

4.1 Conceptual Features of the Geochemical Zones for the IDF Cell 1 that Contains all Types of IDF Wastes and Has Leachate Dominated by Cement.

4.2 Conceptual Features of the Geochemical Zones for the IDF Cell 1 that Contains all Types of IDF Wastes and Has Leachate Outside IDF Dominated by Natural Recharge Water

4.3 Conceptual Features of the Geochemical Zones for Cell 2 that Contains ILAW Glass Only or Cell 1 that has Leachate Dominated by Glass Throughout Vadose Zone

5.1 $\mathrm{K}_{\mathrm{d}}$ Values for Zone 1a - Near Field/Vitrified Waste

5.2 Empirical Solubility Concentration Limits for Designated Solids in Zone 1a - Near Field/ Vitrified Wastes

5.3 $\quad \mathrm{K}_{\mathrm{d}}$ Values for Zone 1b - Near Field/Cementitious Secondary Wastes.

5.4 Empirical Solubility Concentration Limits for Designated Solids for Zone 1b - Near Field/Cementitious Secondary Wastes

5.5 $\mathrm{K}_{\mathrm{d}}$ Values for Zone 2a - Chemically Impacted Far Field in Sand Sequence

5.6 $\quad K_{d}$ Values for Zone 2b - Far Field in Sand Sequence with Natural Recharge

5.7 Gravel-Corrected $\mathrm{K}_{\mathrm{d}}$ Values $\left(\mathrm{K}_{\mathrm{dgc}}\right)$ for Zone 3a - Chemically Impacted Far Field in Gravel Sequence.

5.8 Gravel-Corrected $\mathrm{K}_{\mathrm{d}}$ Values $\left(\mathrm{K}_{\mathrm{dgc}}\right)$ for Zones 3a and 4-Far Field in Gravel Sequence.

5.9 $\mathrm{K}_{\mathrm{d}}$ Values for Zone 5-Unconfined Far-Field Aquifer Conditions.

6.1 Evolution of Recommended $\mathrm{K}_{\mathrm{d}}$ Values $(\mathrm{mL} / \mathrm{g})$ for Selected Key Contaminants .....

6.2 Predicted Composition of Glass Leachate and Long-Term Vadose Zone Pore Water Based on the 2001 STORM Code Calculations

6.3 Composition of the High Ionic-Strength-Simulated Pore Water Solution Used for U(VI) $\mathrm{K}_{\mathrm{d}}$ Measurements by Serne et al. (2002a).

6.4 $\mathrm{K}_{\mathrm{d}}$ Values (mL/g) Measured for U(VI) by Serne et al. (2002a) at Different Initial Concentrations of Dissolved U(VI) Using Hanford Formation Coarse Sand and High Ionic-Strength Solution with the Composition Listed in Table 6.3 
6.5 $\mathrm{K}_{\mathrm{d}}$ Values Measured for U(VI) by Serne et al. (2002a) as a Function of pH Using Hanford Formation Coarse Sand and High Ionic-Strength Solution with the Composition Listed in Table 6.3 ......

6.6 $\mathrm{K}_{\mathrm{d}}$ Values Measured for U(VI) by Serne et al. (2002a) as a Function of Dissolved Inorganic Carbon Using Hanford Formation Coarse Sand and High Ionic-Strength Sodium-BicarbonateSulfate Solution 


\subsection{Introduction}

The Hanford Integrated Disposal Facility Performance Assessment (IDF PA) examines the long-term environmental and human health effects associated with the planned disposal of the vitrified low-activity fraction of waste, i.e., immobilized low-activity waste (ILAW), contained within Hanford Site tanks, as well as low-level waste (LLW), mixed low-level waste (MLLW), and failed or decommissioned melters used for waste vitrification. Greater than $200,000 \mathrm{~m}^{3}$ of tank waste have been created as a result of separating nuclear materials from irradiated nuclear fuels. This waste has been stored in 18 underground tank farms within which are 177 individual tanks. The tank waste is to be retrieved, separated into lowactivity and high-level fractions, and then immobilized by private vendors. The high-level fraction, which will be of low volume but will contain most of the radionuclides, will be vitrified at the Waste Treatment Plant (WTP), then stored at Hanford until a national geologic repository is approved. The lowactivity fraction will be disposed of as vitrified waste in the 200 East Area in the IDF.

The current PA for the IDF is the Hanford Immobilized Low-Activity Waste Performance Assessment: 2001 Version (ILAW PA) (Mann et al. 2001). The ILAW PA is updated annually, most recently as Mann (2003a). The 2001 ILAW PA was prepared assuming that only ILAW would be disposed at the IDF. Mann (2003) acknowledges the anticipated changes in the waste types to be disposed at the facility. A risk assessment for the IDF was prepared recently that considers the combined disposal of ILAW, LLW, MLLW, and failed or decommissioned melters in a single facility (Mann et al. 2003). That risk assessment used information from the ILAW PA (Mann et al. 2001), and the performance assessments completed for the Hanford solid waste burial grounds (Wood et al. 1995, 1996).

The first ILAW PA showed that groundwater transport presents the greatest potential for long-term dose uptake by humans (Mann et al. 1998). Of the numerous radionuclides evaluated in the ILAW PA (including actinium, americium, carbon, cerium, curium, cobalt, cesium, europium, iodine, niobium, nickel, neptunium, protactinium, lead, plutonium, radium, ruthenium, selenium, strontium, tin, technetium, thorium, uranium, and zirconium), the isotopes ${ }^{129} \mathrm{I},{ }^{237} \mathrm{~Np},{ }^{79} \mathrm{Se},{ }^{99} \mathrm{Tc}$, and ${ }^{234 / 235 / 238} \mathrm{U}$ were identified as posing the greatest potential health hazard. Kaplan et al. (1995) described the geochemical factors affecting the transport of these radionuclides in the Hanford Site subsurface environment. It was also determined that the outcome of these simulations was very sensitive to the parameter describing the extent to which radionuclides sorbed to the subsurface sediment, the distribution coefficient, $\mathrm{K}_{\mathrm{d}}$. The distribution coefficient is the ratio of the radionuclide concentration associated with the solid phase to that in the liquid phase (described in more detail in Section 2.0). Near the buried waste, solubility constraints may also control the solution concentrations of contaminants. Thus, this data package contains empirically chosen "solubility concentration limits" for selected contaminants in the regions near the specified wastes.

The purpose of the geochemistry data package is to document the basis for selecting geochemical parameters and input values that will be used in the 2005 version of the IDF PA. This data package includes a discussion of the philosophy and justification for selection and use of the empirical distribution coefficient $\left(\mathrm{K}_{\mathrm{d}}\right)$ and empirical solubility concentration limits as inputs for contaminant migration analyses. Brief descriptions of the geochemistry of several key contaminants of concern, the spatial zone approach, and the resulting tables of information are also provided. Additional data packages prepared in support of the 2005 IDF include information on the disposal facility (Puigh 2004), inventory (Puigh et al. 
2004), waste form release (Pierce et al. 2004), recharge (Fayer and Szecsody 2004), near-field hydrology (Meyer et al. 2004), flow and transport in the natural sediments (Khaleel 2004), and geology (Reidel 2004). 


\subsection{Philosophy}

\subsection{Background}

The concentrations, mobility, and bioavailability of radionuclides and contaminants in sediment pore water and groundwater are controlled primarily by the amount of contaminant present at the source; rate of release from the source; hydrologic factors such as dispersion, advection, and dilution; several geochemical processes including oxidation/reduction, aqueous speciation, adsorption/desorption and precipitation/dissolution, diffusion, colloid-facilitated transport, and anion exclusion. Additionally, in the uppermost layer of surface sediment, the mobility of radionuclides also can be increased by biological activity and the drying and subsequent cracking of sediments. Colloid-facilitated transport and anion exclusion have received considerable attention recently in that they can enhance the transport of certain radionuclides. These processes are hard to quantify, and the extent to which they occur is difficult to determine. The importance of colloid-facilitated migration, especially in aquifer systems that do not involve fracture flow of groundwater, is still a subject of debate. The geochemical processes listed above are discussed in detail in sources such as Baes and Mesmer (1976), Garrels and Christ (1965), Langmuir (1997), Lindsay (1979), Morel (1983), Nordstrom and Munoz (1985), Sposito (1989, 1994), Stumm and Morgan (1981), Yariv and Cross (1979), and others, and in the references cited therein. Table 2.1, taken from the U.S. Environmental Protection Agency (EPA) report Understanding Variation in Partition Coefficient, $K_{d}$, Values: Volume I. The $K_{d}$ Model, Methods of Measurement, and Application of Chemical Reaction Codes (EPA 1999a), summarizes by mechanism, anticipated effects on radionuclide mobility, and key environmental factors associated with each of these geochemical processes. The authors of this report are also principal authors of EPA (1999a) and the other two volumes in this series, Understanding Variation in Partition Coefficient, $K_{d}$, Values: Volume II. Review of Geochemistry and Available $K_{d}$ Values for Cadmium, Cesium, Chromium, Lead, Plutonium, Radon, Strontium, Thorium, Tritium ( ${ }^{3} \mathrm{H}$ ), and Uranium (EPA 1999b); and Volume III. Review of Geochemistry and Available $K_{d}$ Values for Americium, Arsenic, Curium, Iodine, Neptunium, Radium, and Technetium (EPA 2004).

To predict contaminant transport through the subsurface accurately, it is essential that the important geochemical processes affecting contaminant transport be identified and described in a scientifically defensible manner. Adsorption/desorption (including ion exchange) and precipitation/dissolution are considered the most important processes affecting radionuclide interactions with sediments. Precipitation/dissolution is more likely to be an important process where elevated concentrations of dissolved radionuclides exist, such as in the near-field environment of radioactive waste disposal facilities, at spill sites of radionuclide-containing wastes, or where steep $\mathrm{pH}$ or redox gradients exist. Adsorption/ desorption will likely be the key process controlling radionuclide retardation in areas where trace concentrations of dissolved radionuclides exist, such as those associated with far-field environments of disposal facilities or spill sites or in areas where sediments are to be irrigated using radionuclidecontaminated water.

The sorption of radionuclides on sediments is frequently quantified by the partition (or distribution) coefficient, $\mathrm{K}_{\mathrm{d}}$. The $\mathrm{K}_{\mathrm{d}}$ parameter is a factor related to the partitioning of a radionuclide between the solid and aqueous phases and is defined as the ratio of the quantity of the adsorbate adsorbed per mass of solid to the amount of the adsorbate remaining in solution at equilibrium. The terms "partition coefficient" and "distribution coefficient" are used interchangeably in the literature for the $\mathrm{K}_{\mathrm{d}}$ linear isotherm sorption 
Table 2.1. Summary of Chemical Processes Affecting the Mobility of Radionuclides and Contaminants (taken from EPA [1999a])

\begin{tabular}{|c|c|c|c|}
\hline Geochemical Process & Mechanism & $\begin{array}{c}\text { Affect on Radionuclide } \\
\text { Mobility }\end{array}$ & Important Factors \\
\hline $\begin{array}{l}\text { Aqueous } \\
\text { complexation }\end{array}$ & $\begin{array}{l}\text { Reaction where an } \\
\text { aqueous molecular unit } \\
\text { (ion) acts as a central } \\
\text { group to attract and } \\
\text { form a close association } \\
\text { with other atoms or } \\
\text { molecules }\end{array}$ & $\begin{array}{l}\text { May enhance mobility or } \\
\text { retardation, depending on } \\
\text { radionuclide and } \\
\text { geochemical conditions }\end{array}$ & $\begin{array}{l}\text { - Function of } \mathrm{pH} \text { and redox conditions } \\
\text { - Complexation may lower potential for } \\
\text { adsorption or increase solubility, which } \\
\text { can enhance the potential for mobility } \\
\text { - Complexes may more readily bond to } \\
\text { sediments and thus retard migration } \\
\text { - Organic ligands from humic materials } \\
\text { can be present in significant concentra- } \\
\text { tions and dominate radionuclide } \\
\text { complexation in some systems }\end{array}$ \\
\hline $\begin{array}{l}\text { Oxidation/reduction } \\
\text { (redox) reactions }\end{array}$ & $\begin{array}{l}\text { Reaction where } \\
\text { electrons are transferred } \\
\text { completely from one } \\
\text { species to another }\end{array}$ & $\begin{array}{l}\text { May enhance mobility or } \\
\text { retardation, depending on } \\
\text { radionuclide and geo- } \\
\text { chemical conditions }\end{array}$ & $\begin{array}{l}\text { - Change in redox status changes aqueous } \\
\text { speciation, which may increase or } \\
\text { decrease adsorption and solubility } \\
\text { - If redox status is low enough to induce } \\
\text { precipitation of sulfide minerals, repre- } \\
\text { cipitation of some radionuclides may be } \\
\text { expected } \\
\text { - The mobilities of redox-sensitive species } \\
\text { are more difficult to predict because } \\
\text { many redox reactions are kinetically slow } \\
\text { in natural waters, and several elements } \\
\text { may never reach equilibrium between } \\
\text { their various valence states }\end{array}$ \\
\hline $\begin{array}{l}\text { Adsorption/ } \\
\text { desorption and ion } \\
\text { exchange }\end{array}$ & $\begin{array}{l}\text { Special case of a com- } \\
\text { plexation reaction } \\
\text { where there is a net } \\
\text { accumulation of a } \\
\text { radionuclide at the } \\
\text { interface between solid } \\
\text { and aqueous solution } \\
\text { phases; does not include } \\
\text { development of a three- } \\
\text { dimensional molecular } \\
\text { structure }\end{array}$ & Enhances retardation & $\begin{array}{l}\text { - } \begin{array}{l}\text { Occurs primarily in response to } \\
\text { electrostatic attraction }\end{array} \\
\text { - } \text { - } \text { Anion adsorption is greatest at low pH } \\
\text { and decreases with increasing pH } \\
\text { - Cation adsorption is greatest at high pH } \\
\text { and decreases with decreasing pH } \\
\text { - Some radionuclides may be present as } \\
\text { cations or anions depending on pH } \\
\text { - Totally to partially reversible; decline in } \\
\text { dissolved radionuclide concentration may } \\
\text { result in desorption and release of } \\
\text { adsorbed radionuclide to water } \\
\text { - Likely the key process controlling } \\
\text { radionuclide mobility in areas where } \\
\text { chemical equilibrium exists }\end{array}$ \\
\hline
\end{tabular}


Table 2.1. (contd)

\begin{tabular}{|c|c|c|c|}
\hline Geochemical Process & Mechanism & $\begin{array}{c}\text { Affect on Radionuclide } \\
\text { Mobility } \\
\end{array}$ & Important Factors \\
\hline $\begin{array}{l}\text { Precipitation/ } \\
\text { dissolution }\end{array}$ & $\begin{array}{l}\text { Special case of a } \\
\text { complexation reaction in } \\
\text { which the complex } \\
\text { formed by two or more } \\
\text { aqueous species is a solid } \\
\text { with three-dimensional } \\
\text { molecular structure }\end{array}$ & Enhances retardation & $\begin{array}{l}\text { Very dependent on } \mathrm{pH} \text { and redox } \\
\text { conditions } \\
\text { Totally to partially reversible; decline in } \\
\text { dissolved radionuclide concentration } \\
\text { may result in dissolution of precipitated } \\
\text { radionuclide to groundwater } \\
\text { - Likely the process where chemical } \\
\text { nonequilibrium exists, or areas where } \\
\text { high radionuclide concentrations or } \\
\text { steep pH and/or redox gradients exist }\end{array}$ \\
\hline Diffusion & $\begin{array}{l}\text { Molecular process of } \\
\text { transport of matter in the } \\
\text { absence of advection }\end{array}$ & Enhances mobility & $\begin{array}{l}\text { - Flux of matter due to diffusion is } \\
\text { proportional to concentration gradient }\end{array}$ \\
\hline $\begin{array}{l}\text { Colloid-facilitated } \\
\text { transport }\end{array}$ & $\begin{array}{l}\text { Radionuclides associated } \\
\text { with suspended fine- } \\
\text { grained material (smaller } \\
\text { than clay size) that may } \\
\text { be transported with } \\
\text { flowing sediment pore } \\
\text { water and groundwater }\end{array}$ & Enhances mobility & $\begin{array}{l}\text { Little information on occurrence, } \\
\text { mineralogical and physicochemical } \\
\text { properties, or conditions conducive to } \\
\text { the generation of mobile colloids } \\
\text { - May originate from dispersion of } \\
\text { sediments, decementation of secondary } \\
\text { mineral phases, and/or precipitation of } \\
\text { groundwater constituents } \\
\text { - Difficult to collect colloids from sub- } \\
\text { surface in a way that minimizes or } \\
\text { eliminates sampling artifacts } \\
\text { Difficult to delineate unambiguously } \\
\text { between radionuclides in the mobile- } \\
\text { aqueous and mobile-solid phases }\end{array}$ \\
\hline Anion exclusion & $\begin{array}{l}\text { Occurs when the diffuse } \\
\text { double layer, an } \\
\text { extension of a particle's } \\
\text { negative surface charge } \\
\text { into the surrounding } \\
\text { solution, repulses anions }\end{array}$ & $\begin{array}{l}\text { Enhances mobility to a } \\
\text { limited extent }\end{array}$ & $\begin{array}{l}\text { By excluding anions from the diffuse } \\
\text { double layer, where water is relatively } \\
\text { immobile, anions are restricted to the } \\
\text { faster-moving pore water, resulting in } \\
\text { an average rate of anion transport } \\
\text { greater than the average pore-water } \\
\text { velocity defined by Darcy's Law } \\
\text { More pronounced with higher cation } \\
\text { exchange capacity, or negative charge, } \\
\text { of sediment or rock. }\end{array}$ \\
\hline
\end{tabular}

model. Radionuclides that adsorb very strongly to sediment have large $\mathrm{K}_{\mathrm{d}}$ values (typically greater than $100 \mathrm{~mL} / \mathrm{g}$ ) compared with radionuclides that are not significantly retarded by adsorption. Radionuclides that do not adsorb to sediment and migrate essentially at the same rate as the water flow have $\mathrm{K}_{\mathrm{d}}$ values near $0 \mathrm{~mL} / \mathrm{g}$. The $\mathrm{K}_{\mathrm{d}}$ model is the simplest yet least robust sorption model available, yet it is the most common measure used in hydrologic transport and biosphere codes to describe the extent to which contaminants are sorbed to sediments. The primary advantage of the $\mathrm{K}_{\mathrm{d}}$ model is that it is inserted easily into computer codes to quantify the reduction in the extent of transport of a radionuclide relative to groundwater. The $\mathrm{K}_{\mathrm{d}}$ is an empirical unit of measurement that attempts to account for various chemical and physical retardation mechanisms that are influenced by a myriad of variables. The technical issues, 
complexities, and shortcomings of the $\mathrm{K}_{\mathrm{d}}$ approach to describing radionuclide sorption to sediments are discussed in detail in EPA (1999a) and the references cited therein. Cantrell et al. (2002) discuss the scientific basis for application of the $\mathrm{K}_{\mathrm{d}}$ model to the complex wastes of the Hanford Site (Section 2.3).

Throughout this report (especially in Section 3), "sorption" is used as a generic term devoid of mechanism to describe the partitioning of dissolved aqueous-phase constituents to a solid phase. When a radionuclide is associated with a geologic material, it is often not known whether the radionuclide is

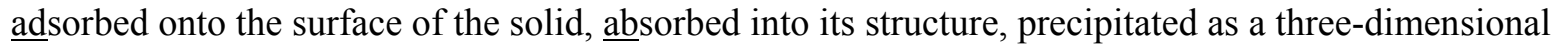
molecular structure on the surface of the solid, or partitioned into the organic matter (Sposito 1989). The term "sorption" is used to encompass all of these processes when the authors do not have enough information to distinguish the exact mechanism that is controlling the partitioning of the constituent of interest. When discussing the $K_{d}$ values and empirical solubility concentration limits selected for the 2005 IDF PA, we attempted to be explicit when referring to and differentiating between adsorption- or solubilitycontrolled processes.

\subsection{Relationship Between Distribution Coefficients and Retardation Factors}

The distribution coefficient, or $\mathrm{K}_{\mathrm{d}}$ value, is the simplest construct describing contaminant sorption to sediments. It is the ratio of the contaminant concentration sorbed to the solid phase divided by the contaminant concentration in the liquid surrounding the solid phase (Equation 2.1):

$$
K_{d}=\frac{C_{\text {solid }}}{C_{\text {liquid }}}
$$

where $C_{\text {solid }}(\mathrm{M} / \mathrm{kg})$ and $C_{\text {liquid }}(\mathrm{M} / \mathrm{L})$ are the concentration in the solid and liquid phases, respectively. Sorption, as expressed by $\mathrm{K}_{\mathrm{d}}$ values, is normalized by weight. Contaminant transport modelers commonly use $\mathrm{K}_{\mathrm{d}}$ values to account for chemical interactions between the contaminant and the sediment. The $\mathrm{K}_{\mathrm{d}}$ value is used to define the retardation factor, which is the ratio of the average linear velocity of water $(\mathrm{m} / \mathrm{s})$ divided by the average linear velocity of the contaminant $(\mathrm{m} / \mathrm{s})$. For water-saturated systems, the $K_{d}$ value is related to the retardation factor (Rf, unitless) by the bulk density $\left(\rho_{b}, \mathrm{~kg} / \mathrm{m}^{3}\right)$ and the porosity $\left(\eta, \mathrm{m}^{3} / \mathrm{m}^{3}\right.$ ) (Valocchi 1985; Bouwer 1991) as follows:

$$
R f=\left(1+\frac{K_{d} \rho_{b}}{\eta}\right)
$$

The bulk density and porosity terms in Equation 2.2 convert the weight-normalized $\mathrm{K}_{\mathrm{d}}$ value into a volume-normalized value. For partially saturated sediments, the porosity term is replaced by the volumetric water content of the vadose zone sediments.

\subsection{Empirical $\mathrm{K}_{\mathrm{d}}$ Construct}

The geochemical behavior of radionuclides in the subsurface that are used in the IDF PA are based on two parameters, the distribution coefficient $\left(\mathrm{K}_{\mathrm{d}}\right)$ value and empirical solubility concentration limit of a specified solid. In its strictest usage, the distribution coefficient is a quasi-thermodynamic construct. It is the ratio of the concentration of a species reversibly adsorbed/exchanged to a geomedium's surface sites 
divided by the concentration of the species in the surrounding solution. Using uranyl as an example, the definition of a species-specific $\mathrm{K}_{\mathrm{d}}$ as a quasi-thermodynamic construct is

$$
K_{d-\text { thermo }}=\frac{X \equiv U O_{2}^{2+}}{U O_{2}^{2+}}
$$

where $\mathrm{X} \equiv \mathrm{UO}_{2}{ }^{2+}$ is the activity of the uranyl species reversibly adsorbed to a specific surface site $\mathrm{X}$, and $\mathrm{UO}_{2}{ }^{2+}$ is the activity of dissolved "free" uranyl species at equilibrium with the surface site $\mathrm{X}$. Among the many assumptions underpinning $\mathrm{K}_{d \text {-thermo }}$ are that adsorption is fully reversible, and the presence of adsorbed uranyl species does not influence subsequent adsorption of other dissolved uranyl or other contaminant species. Thus, a single distribution coefficient is used to represent both sorption and desorption of each contaminant species.

To apply the $\mathrm{K}_{\mathrm{d}}$ construct to contaminant transport and performance assessment calculations, the definition of the construct is relaxed for several reasons. In natural systems, many types of sorption sites exist. Also, it is not possible to measure the thermodynamic activity of individual chemical species on the adsorbents' surfaces. Furthermore, the measurement of thermodynamic activities of dissolved species is rarely performed and, as just mentioned for adsorbates on solids, no techniques exist for measuring their thermodynamic activity. The parameters that can be measured readily are the total contaminant concentration or radionuclide activity (not to be confused with thermodynamic activity) as opposed to the concentration or radioactivity of each individual species. Thus the quasi-thermodynamically based $\mathrm{K}_{\mathrm{d}}$ construct, as defined in Equation 2.3, requires differentiating and quantifying each type of surface site and each solution species. Additionally, spatial variability of the surface sites and groundwater chemistry in natural systems cannot be characterized practicably to the degree necessary for the full implementation of species-specific sorption models such as the triple layer surface complexation model (see Kent et al. [1988] for a good overview and Jenne [1998] for a recent compilation of related articles).

The empirical definition of the $\mathrm{K}_{\mathrm{d}}$ value becomes the ratio of the concentration of the complete suite of species (the sum of the concentrations of all species that includes the contaminant of interest) sorbed by an assemblage of surface sites divided by the summed concentration of the suite of species (total concentration) in solution. Again, using uranyl as an example, the definition of the quasi-thermodynamic $\mathrm{K}_{\mathrm{d}}$ construct would be for a simple system that contained three $\mathrm{U}(\mathrm{VI})$ species $\left[\mathrm{UO}_{2}{ }^{2+}, \mathrm{UO}_{2}(\mathrm{OH})^{+}\right.$, and $\left.\mathrm{UO}_{2}(\mathrm{OH})_{2}{ }^{0}(\mathrm{aq})\right]$ :

$$
K_{d-\text { therm }}=\frac{\sum \text { Adsorbed } U \text { Species }}{\sum \text { Dissolved } U \text { Species }}=\frac{X \equiv \mathrm{UO}_{2}^{2+}+X \equiv \mathrm{UO}_{2}(\mathrm{OH})^{+}+X \equiv \mathrm{UO}_{2}(\mathrm{OH})_{2}^{0}}{U O_{2}^{2+}+U \mathrm{O}_{2}(\mathrm{OH})^{+}+U \mathrm{O}_{2}(\mathrm{OH})_{2}^{0}}
$$

where $\mathrm{X} \equiv$ is an average sorbent site (more than one sorbent site type is expected in nature). The numerator and denominator in Equation 2.4a are summed over contaminant species sorbed as well as sorbent sites. The empirical $\mathrm{K}_{\mathrm{d}}$ equation would be

$$
K_{d}=\frac{\text { Total } U(V I) \text { on Solid }}{\text { Total } U(V I) \text { in Solution }}
$$


Among the reasons for selecting the "empirical" $\mathrm{K}_{\mathrm{d}}$ construct for the IDF PA, as exemplified by Equation $2.4 \mathrm{~b}$, are the following:

1. The bulk of the existing sorption literature on radionuclide sorption, especially at the Hanford Site, can be classified as "empirical" $\mathrm{K}_{\mathrm{d}}$ values.

2. Under the expected low concentrations of the contaminants in the far field, sorption can be considered to be independent of contaminant concentration and, therefore, $\mathrm{K}_{\mathrm{d}}$ is a constant for a given contaminant/geological material combination under identical (geo)chemical conditions.

3. The $\mathrm{K}_{\mathrm{d}}$ can be used directly in codes used for performance assessments, such as PORFLO, VAM3DF, and STOMP used in Hanford Site far-field vadose zone transport calculations (see Khaleel 1999).

4. Perhaps most important, there is no thermodynamically based conceptual model or numerical code that is robust enough to accurately predict the degree of radionuclide adsorption by natural sediments (see below).

The current vision for Hanford Site-wide cumulative risk assessments performed with the System Assessment Capability (SAC) (Kincaid et. al. 2000) is to represent contaminant adsorption using the empirical distribution coefficient, $\mathrm{K}_{\mathrm{d}}$, (or linear isotherm) sorption model. Review comments from the Integration Project Expert Panel (IPEP) indicate that work is required to justify the applicability of the empirical $K_{d}$ sorption model and to identify and defend the range of $K_{d}$ values that are adopted for assessments. The work plans developed for the DOE Hanford Science and Technology (S\&T) Program within the Hanford Site Groundwater/Vadose Zone Integration Project (Integration Project) efforts, SAC, and the core projects of the Integration Project must answer the question, "Is there a scientific basis for the application of the linear sorption isotherm model to the complex wastes of the Hanford Site?" The paper by Cantrell et al. (2002), Hanford Contaminant Distribution Coefficient Database and Users Guide, was intended specifically to address this question. The following conclusions and recommendations were taken essentially verbatim from Section 6 of Cantrell et al. (2002). The general thesis of the cited paper is that the empirical $\mathrm{K}_{\mathrm{d}}$ construct will continue to be used at Hanford for overall system performance activities and selected key contaminants and geochemical environments will be studied in a more mechanistic way. We concur with the Cantrell et al. (2002) thesis and cited justifications.

- "The linear adsorption model or $\mathrm{K}_{\mathrm{d}}$ approach is a useful and practical approach for modeling contaminant adsorption in transport performance assessments. This empirical approach has the advantage of being simple, and a considerable database of Hanford specific $\mathrm{K}_{\mathrm{d}}$ values measured under a variety of conditions is available."

- "An inherent drawback of this approach is its empirical nature. Because the variation in a $\mathrm{K}_{\mathrm{d}}$ value cannot be confidently estimated beyond the range of chemical conditions under which it was measured, the utility of any $\mathrm{K}_{\mathrm{d}}$ measurement may be good only for that specific set of conditions. This limitation is not a significant problem as long as the site-specific conditions being modeled do not deviate significantly from those for which $\mathrm{K}_{\mathrm{d}}$ measurements are available. For situations in which the concentrations of chemical parameters change rapidly within a small spatial zone (e.g., under a leaking high-level waste tank), $\mathrm{K}_{\mathrm{d}}$ values generally are not available for all the important contaminants as 
a function of all the important parameters in sufficient detail to provide transport modeling results that are sufficiently accurate. In this situation, several approaches could be taken. Each of the possible approaches will require a more detailed knowledge of the geochemical parameters and mechanisms that control adsorption of a particular contaminant under site-specific conditions. The more scientifically rigorous approach would be to conduct detailed mechanistic adsorption studies to determine the influence of all the important geochemical parameters over a broad range of concentrations that could potentially influence adsorption for each contaminant of interest. This approach is likely to be costly and time consuming. A faster and more economical alternative to the more scientifically rigorous approach is to apply available mechanistic information to design an adsorption study in which $\mathrm{K}_{\mathrm{d}}$ values are determined over a range of geochemical parameters that have the greatest influence on adsorption. This study would be limited to contaminants that pose the greatest potential risk. It is likely that this approach would only be required for the limited number of waste sites where high concentration wastes were discharged or at leaking high-level waste tank sites. Although this approach is not as ideal as a completely mechanistic approach, it would provide a method to obtain more reliable modeling results in a more economical and timely fashion." This is the approach that was adopted for the IDF geochemical portion of the IDF PA project. Key contaminants that have been studied in a more mechanistic fashion to date include ${ }^{129} \mathrm{I},{ }^{99} \mathrm{Tc},{ }^{79} \mathrm{Se}$, and $\mathrm{U}$.

- "As a means of increasing the scientific defensibility of using the $\mathrm{K}_{\mathrm{d}}$ approach for estimating adsorption in performance assessment modeling, it is recommended that a detailed comparison be made with a transport model in which a more rigorous mechanistic approach to adsorption is used."

Using site-specific materials in IDF-funded experiments, it is possible to gather relevant data directly and not rely on extrapolation from other sediment and aqueous systems. The problem with the rigorous thermodynamic species approach is that there is no numerical or conceptual model developed that is sufficiently robust to predict accurately the degree of radionuclide adsorption by natural sediment (Sposito 1984; Westall 1986, 1995; Wang et al. 1997; Davis et al. 1998). Mechanistic models, though impractical for PA purposes, provide the necessary paradigms on which technically defensible empirical $\mathrm{K}_{\mathrm{d}}$ values must be based. For most of the data used in the IDF PA geochemical data package, sorption experiments have been conducted with site-specific sediment and site-specific groundwater, which resembles natural vadose zone pore waters, and simulated glass leachate. Future work will expand the leachates studied to include grout or cementitious waste fluids, both "fresh" alkaline and "aged" carbonated fluids that represent the evolution of cement in subsurface environments (see Krupka and Serne [1998] for more discussion on cement mineral and pore water evolution.)

Another aspect of the $\mathrm{K}_{\mathrm{d}}$ construct that is typically relaxed when used in contaminant transport calculations is the chemical process that it describes. As pointed out earlier, Equation 2.3 implies an adsorption or exchange reaction that is reversible. The laboratory $\mathrm{K}_{\mathrm{d}}$ measured with complex natural sediments and perhaps complex natural groundwater solutes often reflect not only adsorption and exchange reactions, but also absorption, specific or somewhat irreversible adsorption, surface complexation, and varying degrees of coprecipitation reactions. Identifying the processes that govern radionuclide chemical behavior is the single most important task needed for estimating $\mathrm{K}_{\mathrm{d}}$ values for the IDF PA. Once the dominant geochemical process is identified for a specific geological and chemical environment, the range of empirical $\mathrm{K}_{\mathrm{d}}$ values can be narrowed. Radionuclide geochemical processes have been ascertained primarily through experiments in which a key parameter is systematically varied (e.g., suspension $\mathrm{pH}$ or ionic strength). The trends displayed during these experiments provide key information 
regarding radionuclide behavior and also shed light on which processes may be controlling the radionuclide interaction between the solid and liquid.

The importance of first identifying the dominant geochemical process affecting radionuclide concentrations in the mobile aqueous phase can be illustrated through an experiment conducted for this project (Kaplan et al. 1998a). In this experiment, as the $\mathrm{pH}$ of Hanford Site sediment-groundwater slurries was increased from $\mathrm{pH} 8$ to $10, \mathrm{~K}_{\mathrm{d}}$ values for $\mathrm{U}(\mathrm{VI})$ gradually increased from 1.3 to $3.5 \mathrm{~mL} / \mathrm{g}$. Above $\mathrm{pH} 10.5$ the amount of U(VI) removed from the aqueous phase increased more than 500-fold. The initial increase in $\mathrm{K}_{\mathrm{d}}$ between $\mathrm{pH} 8$ and 10 was attributed to increased cation exchange capacity of the sediment. That is, the number of $\mathrm{pH}$-dependent adsorption sites in the natural sediment that attract cations increased as $\mathrm{pH}$ increased. The latter, more dramatic increase was attributed to coprecipitation of U(VI) with carbonate solid phases that were generated as the $\mathrm{pH}$ increased. These conclusions were supported by independent solubility calculations. What we learn from this particular study is much more than that the magnitude of the $\mathrm{K}_{\mathrm{d}}$ value should be used as an input parameter to the IDF PA; we also gain a plausible explanation of the processes governing $\mathrm{U}(\mathrm{VI})$ removal from solution. As this example illustrates, changes in the dominating chemical processes may account for an appreciable amount of variability in derived $\mathrm{K}_{\mathrm{d}}$ values under different geochemical conditions.

\subsection{Solubility Constraints}

In addition to the $\mathrm{K}_{\mathrm{d}}$ construct, solubility products, both thermodynamically and empirically based, are being used to describe radionuclide geochemical behavior in the IDF. Solubility constraints are used for conditions in which the calculated total concentration of the radionuclide and its stable isotopes is believed to exceed the solubility of an assumed controlling phase. The selection of controlling solid phases is based on laboratory experiments and, when experimental data are not available, on literature findings. If the thermodynamic data for the solid phase are not available from laboratory experiments or the literature, they will be calculated using chemical speciation and solubility algorithms. Once the solid phase is selected, the upper limit of the solution concentration of the radionuclide and its stable isotopes will be calculated with the appropriate background electrolyte composition. If the background electrolyte composition remains essentially constant, the solubility product can be assumed to be nearly constant as well. This has led some performance assessment practitioners to refer to solubility constraints as constants, but in reality the solubility constant, $\mathrm{K}_{\mathrm{sp}}$, varies with solution chemistry. When radionuclide concentrations exceed the $\mathrm{K}_{\mathrm{sp}}$ precipitation can be expected, and subsequent radionuclide aqueous concentrations and behavior are controlled by solubility until the solution concentrations drop below the solubility constraining value. At concentrations below this limit, the radionuclide concentration will be controlled by the empirical $\mathrm{K}_{\mathrm{d}}$ construct. When the controlling solid cannot be identified but empirical solubility tests clearly indicate that some unidentified phase is controlling solution concentration, an empirical solubility relationship is used. This empirical solubility product includes the key solution parameters as independent variables and the empirical solubility product as the dependent variable. In some cases, the empirical $\mathrm{K}_{\mathrm{sp}}$ data may be simplified as a constant solubility concentration limit. This is especially true for the 2005 IDF PA because little site/waste form/engineered barrier solubility work has been done to identify the controlling solids. Recently published critical reviews and tabulations of thermodynamic constants completed by the Nuclear Energy Agency (NEA) of the Organisation for Economic Cooperation and Development (OECD) in Palaiseau, France (with multinational funding) are valuable resources for thermodynamic solubility constants. Five compilations are available for the thermodynamic constants for aqueous, solid, and gaseous species containing uranium, americium, 
technetium, neptunium, and plutonium (including an update of the earlier published constants) (Grenthe et al. 1992; Silva et al. 1995; Rard et al. 1999; Lemire et al. 2001; Guillaumont et al. 2003).

\subsection{Parametric-K $\mathbf{K}_{\mathrm{d}}$ Model}

When using the constant $\mathrm{K}_{\mathrm{d}}$ model, the retardation factor is a constant for each layer of geologic media (each layer is assumed to have a constant bulk density and water content or effective porosity). The transport equation based on a constant $\mathrm{K}_{\mathrm{d}}$ model does not require knowledge of any other geochemical parameters such as $\mathrm{pH}$ or mineralogy, and it is easily solved to determine the solution concentration as a function of time and space. Using the constant $\mathrm{K}_{\mathrm{d}}$ model in a retardation factor (Equation 2.2) has caused most of the criticism; few natural groundwater pathways are spatially or geochemically homogeneous to the extent that the retardation factor for a species remains constant for all locations and times.

Clearly, the greatest limitation to the constant $\mathrm{K}_{\mathrm{d}}$ approach is that it describes solute partitioning between the aqueous and solid phases for only one set of environmental conditions. Such homogeneity does not exist in nature, and therefore greatly compromises the usefulness of the constant. For instance, when the aqueous phase chemistry was varied, $K_{d}$ values for americium in a Hanford Site sediment ranged from 0.2 to $53 \mathrm{~mL} / \mathrm{g}$, roughly a 200-fold range (Delegard and Barney 1983). Additional variability in the $\mathrm{K}_{\mathrm{d}}$ values for americium, though less, was observed when slightly different Hanford Site sediments were used: 4.0 to $28.6 \mathrm{~mL} / \mathrm{g}$ (Delegard and Barney 1983, Solution 1). Using similar aqueous phases but sediments from around the country, Sheppard et al. (1976) measured $\mathrm{K}_{d}$ values for americium ranging from 125 to $43,500 \mathrm{~mL} / \mathrm{g}$. (Interestingly, the lowest $\mathrm{K}_{\mathrm{d}}$ in this survey of $12 \mathrm{soils} / \mathrm{sediments}$ from U.S. Department of Energy [DOE] national laboratories was found for a Hanford sediment.)

The $\mathrm{K}_{\mathrm{d}}$ value in the parametric model varies according to empirically derived relationships with aqueous and solid phase independent parameters. Thus, it has the distinct advantage of being more robust and removes the burden of determining new $\mathrm{K}_{d}$ values for each environmental condition. Because $\mathrm{K}_{\mathrm{d}}$ is a function of a large number of variables, it is common to systematically vary several parameters simultaneously in one experiment. Factorial design strategies are most often invoked to determine the systematic change in the dependent variables such as the distribution coefficient resulting from varying the independent variables (Cochran and Cox 1957; Davies 1954; Plackett and Burman 1946; Box and Behnken 1960). Statistical methods commonly used to derive quantitative predictor equations include standard linear or nonlinear regression (Snedecor and Cochran 1967), stepwise regression (Hollander and Wolfe 1973), and adaptive learning networks (Mucciard et al. 1979, 1980). These techniques have been used to develop empirical relationships describing $\mathrm{K}_{\mathrm{d}}$ values in terms of other variables for specific Hanford conditions (Routson and Serne 1972; Serne et al. 1973; Routson et al. 1981; Delegard and Barney 1983).

The empirical predictor equations commonly take the form of a nonlinear multinomial expression. For example, after evaluating solutions consisting of several sodium salts, organic chelates, and acids, Delegard and Barney (1983) came up with the following expression for a $\mathrm{K}_{\mathrm{d}}$ value for americium on one particular Hanford sediment:

$$
\log \left[\mathrm{K}_{\mathrm{d}}(\mathrm{Am})\right]=2.0+0.1[\mathrm{NaOH}]-26.8[\mathrm{HEDTA}]+153.4[\mathrm{HEDTA}]^{2}
$$

The independent parameters and ranges used to develop Equation 2.5 were selected to simulate a plume of high-level waste that emanates from a steel-lined concrete tank into sediment in the Hanford 
Central Plateau. Numerous salts were found to have no significant effect on americium $\mathrm{K}_{\mathrm{d}}$ values so were not included in the expression. Delegard and Barney (1983) also evaluated higher exponential and logarithmic terms and determined that these terms did not improve the predictive capabilities of the parametric $\mathrm{K}_{d}$ expression (i.e., the regression coefficients were not significant at $\mathrm{P}<0.05$ ).

Although the empirical relationships generated from these types of statistical analyses are more powerful than knowledge of individual $\mathrm{K}_{\mathrm{d}}$ values, they cannot be used to predict $\mathrm{K}_{\mathrm{d}}$ values for conditions beyond the range studied. For example, the parametric $\mathrm{K}_{\mathrm{d}}$ values generated by Delegard and Barney (1983) for the Central Plateau are likely inappropriate for the ILAW plume because the chemistry of the aqueous phase leaving the IDF will be appreciably different than fluids leaked from single-shell tanks.

These types of statistical relationships are devoid of causality and therefore provide no certain information on the mechanism by which the radionuclide partitioned to the solid phase, whether by adsorption, absorption, precipitation, or coprecipitation. That is, the statistical analyses may suggest a very strong relationship between one variable, for instance, $\mathrm{pH}$, and the distribution coefficient, when the actual sorption process may be controlled by iron oxide adsorption. Because $\mathrm{pH}$ and iron oxide surface charge are covariant, a statistical relationship could be calculated suggesting that sorption is solely caused by $\mathrm{pH}$.

The parametric $\mathrm{K}_{\mathrm{d}}$ model can be used in the retardation factor term (Equation 2.2). When used in a transport equation, the transport code must also track the value of the independent variables such as $\mathrm{NaOH}$ and HEDTA for the example described in Equation 2.5 at each point in space and time. Tracking other variables is necessary to continually update the concentration of these independent variables that change the $\mathrm{K}_{\mathrm{d}}$ value. Thus, the code must track many more parameters, and some numerical solving techniques such as closed-form analytical solutions can no longer be used to perform the integration needed to solve for the contaminant's concentration. Generally, computer codes that can accommodate the parametric $K_{d}$ model use a chemical subroutine to update the $K_{d}$ value used to determine the $R f$ when called by the main transport code. The added complexity in solving the transport equation with parametric $\mathrm{K}_{\mathrm{d}}$ sorption models and its empirical nature may be the reasons this technique has been used sparingly for waste disposal safety assessment exercises (e.g., see application of parametric $\mathrm{K}_{\mathrm{d}}$ model by Routson and Serne [1972]).

\subsection{Overview of Mechanistic Adsorption Models}

Mechanistic models explicitly accommodate the dependency of adsorption values on contaminant concentration, competing ion concentrations, variable surface charge on the adsorbent, and solute species distribution. Incorporating mechanistic or semimechanistic concepts into adsorption models is attempted because such models become more robust and, perhaps more importantly from the standpoint of the IDF PA, more scientifically defensible. There are several mechanistic models describing solute adsorption; some are accurate only under limited environmental conditions (Sposito 1984). For instance, the Stern model is better for describing adsorption of inner sphere complexes, whereas the Gouy-Chapman model is better for describing outer sphere or diffuse swarm adsorption (Sposito 1984; Westall 1986). The complexity of installing these adsorption models into existing transport codes that are favored for disposal system performance assessment and the diversity of Hanford Site waste leachate/sediment/contaminant combinations of interest would require a data collection effort more intense and costly than is likely to 
occur. A brief description of the state of the science is presented below. References to excellent review articles have been included in the discussion to provide the interested reader with additional information.

Several mechanistic models have been proposed, but their application to complex natural sediments has not been resolved (Westall and Hohl 1980; Sposito 1984; Westall 1986; Schindler and Sposito 1991). Any complete mechanistic description of chemical reactions at the mineral-electrolyte interface must include a description of the electrical double layer. While this fact has been recognized for years, a satisfactory description of the double layer at the mineral-electrolyte interface still does not exist.

Part of the difficulty of characterizing this interface stems from the fact that natural mineral surfaces are very irregular. They consist of many different microcrystalline structures that exhibit quite different chemical properties when exposed to solutions. Thus, examination of the surface by virtually any experimental method yields only average characteristics of the surface and the interface. Parson (1982) discussed the surface chemistry of single crystals of pure metals and showed that the potential of zero charge of different crystal faces on the same pure metal can differ by over $400 \mathrm{mV}$. For an oxide surface, this difference was calculated by Westall (1986) to be energetically equivalent to a variation in the zero-pointof-charge of more than $6 \mathrm{pH}$ units. This example indicated that an observable microscopic property of a polycrystalline surface might result from a combination of widely different microscopic properties and that characterization of these surfaces will remain somewhat operational in nature.

Another fundamental problem encountered in characterizing reactions at the mineral-electrolyte interface is the coupling between electrostatic and chemical interactions, which makes it difficult to distinguish which interaction causes what effects. Westall and Hohl (1980) have shown that many models for reactions at the mineral-electrolyte interface are indeterminate in this regard.

Many of the studies from which our understanding of reactions at the mineral-electrolyte interface has developed were based on titration of suspensions of minerals. Resolving questions left open by such research requires that the mineral surfaces be defined better (by many different spectroscopic and experimental methods) and that mathematical methods be developed for interpreting the data.

Experimental data on interactions at the mineral-electrolyte interface can be represented mathematically through empirical models and mechanistic models. An empirical model can be defined as a mathematical description of the experimental data without any particular theoretical basis. For example, the $\mathrm{K}_{\mathrm{d}}$, Freundlich isotherm, Langmuir isotherm, Langmuir Two-Surface Isotherm, and Competitive Langmuir are considered empirical models by this definition (Sposito 1984). Mechanistic models are based on thermodynamic concepts such as reactions described by mass action laws and material balance equations. Four of the most commonly used mechanistic models include the Helmholtz, Gouy-Chapman, Stern, and Triple Layer models (Sposito 1984). Empirical models are often mathematically simpler than mechanistic models and are suitable for characterizing sets of experimental data with a few adjustable parameters or for interpolating between data points. On the other hand, mechanistic models contribute to an understanding of the chemistry at the interface and are often used for describing data from complex multicomponent systems for which the mathematical formulation (i.e., functional relations) for an empirical model might not be obvious. Mechanistic models can also be used for interpolation and characterization of data sets in terms of a few adjustable parameters. However, mechanistic models are often mathematically more complicated than empirical relationships. Adjustable parameters are required for both mechanistic and empirical models but not for the $\mathrm{K}_{\mathrm{d}}$ model. 
Application of mechanistic adsorption models for studying the retardation of contaminants in Hanford sediments has been limited but some studies are in progress. Barnett et al. (2002) used an extension of the diffuse double-layer surface complexation model developed for the U(VI) adsorption onto ferrihydrite by Waite et al. (1994) to predict U(VI) adsorption as a function of $\mathrm{pH}$ on sediment samples from the Upper Ringold Formation. J. A. Davis ${ }^{(a)}$ and coworkers at the U.S. Geological Survey are using a generalized surface complexation model based on the approach described in Davis and Curtis (2003) and Curtis et al. (2004) to model and study the retardation of uranium in the Hanford 300 Area plume in 300-FF-5. The studies by Barnett et al. (2002) and Davis are discussed Section 3.7.3.

\subsection{Gravel-K $\mathbf{K}_{\mathrm{d}}$ Issue}

Essentially all $\mathrm{K}_{\mathrm{d}}$ values in the literature and most that have been measured at the Hanford Site were generated from sediments that do not contain any gravel, i.e., particles greater than $2 \mathrm{~mm}$. Some subsurface regions of the IDF site are composed primarily of gravel-sized particles; in fact, the graveldominated strata below the IDF site contain at least $90 \%$ by mass particles larger than $2 \mathrm{~mm}$ (see Reidel 2004). At issue is that $K_{d}$ values for some contaminants may be lower in sediments containing gravel because of the reduced surface area in the field compared to the lab-tested solids with which the radionuclides interact. This is referred to as the gravel $\mathrm{K}_{\mathrm{d}}$ issue. Experiments were conducted with Hanford sediments to evaluate methods to address the gravel $\mathrm{K}_{\mathrm{d}}$ issue (Kaplan et al. 1999; Appendix A of this document). Three gravel-corrected $\mathrm{K}_{\mathrm{d}}$ conceptual models, $\mathrm{K}_{\mathrm{dgc}}$, were evaluated in Kaplan et al. (1999): 1) a correction based on surface area $\left.\left(\mathrm{K}_{\mathrm{dgc} \text {,surf }}\right), 2\right)$ a correction based on the assumption that the gravel simply diluted the $\mathrm{K}_{\mathrm{d} 2 \mathrm{~mm}}$ and had no sorption capacity $\left(\mathrm{K}_{\mathrm{dgc}, \mathrm{g}=0}\right)$, and 3 ) a correction based on the assumption that the $\mathrm{K}_{\mathrm{d}}$ of the entire sediment $\left(\mathrm{K}_{\mathrm{dtot}}\right)$ was a composite of the $\mathrm{K}_{\mathrm{d}<2 \mathrm{~mm}}$ and the $\mathrm{K}_{\mathrm{d}>2 \mathrm{~mm}}$ values $\left(\mathrm{K}_{\mathrm{dgc}, \mathrm{g}=\mathrm{x}}\right)$. Based on data for the adsorption of trace concentrations of strontium, on average, $\mathrm{K}_{\mathrm{d}<2 \mathrm{~mm}}$ tended to overestimate $\mathrm{K}_{\mathrm{dtot}}$ by $28 \%$; $\mathrm{K}_{\mathrm{dgc}, \mathrm{g}=\mathrm{x}}$ overestimated $\mathrm{K}_{\mathrm{dtot}}$ by only $5 \% ; \mathrm{K}_{\mathrm{dgc}, \mathrm{g}=0}$ and $\mathrm{K}_{\mathrm{dgc}, \text { surf }}$ underestimated $\mathrm{K}_{\mathrm{dtot}}$ by 10 and $13 \%$, respectively. Although, $\mathrm{K}_{\mathrm{dgc}, \mathrm{g}=\mathrm{x}}$ provided the best estimate of actual values $\left(\mathrm{K}_{\mathrm{dtot}}\right)$, the input values for $\mathrm{K}_{\mathrm{dgc}, \mathrm{g}=0}$ are appreciably easier to acquire. See Appendix A for additional data on the gravel correction.

The $\mathrm{K}_{\mathrm{dgc}, \mathrm{g}=0}$ was used to correct for the conservative case "empirical" $\mathrm{K}_{\mathrm{d}}$ values in the graveldominated sequence in the IDF stratigraphy (described in more detail below) and is defined as

$$
K_{d g c, g=0}=(1-g) K_{d<2 m m}
$$

where $g$ is the gravel weight fraction of sediment in the field and $\mathrm{K}_{\mathrm{d}<2 \mathrm{~mm}}$ is the traditional $\mathrm{K}_{\mathrm{d}}$ value measured using the less than 2-mm fraction. Equation 2.6 greatly improves the accuracy of the empirical $\mathrm{K}_{\mathrm{d}}$ construct for Hanford sediments for contaminants that sorb to Hanford sediments mainly by surface areadominated and cation exchange-dominated reactions. Some contaminants that belong in these two categories are cesium, strontium, radium, and many lanthanides and transition metal fission products. It is not clear that the adsorption of actinides and oxyanion metals such as pertechnetate [Tc(VII)], chromate $[\mathrm{Cr}(\mathrm{VI})]$, uranyl $[\mathrm{U}(\mathrm{VI})]$, and selenate $[\mathrm{Se}(\mathrm{VI})]$ is realistically predicted using Equation 2.6 and its underlying construct. From the standpoint of the IDF PA, Equation 2.6 provides a more conservative $\mathrm{K}_{\mathrm{d}}$ value than the traditional $\mathrm{K}_{\mathrm{d}<2 \mathrm{~mm}}$ commonly used in performance assessment calculations for most soils and sediments. Because the stratigraphic profile below the IDF site (see Section 4.0) does contain zones of

(a) U.S. Geological Survey, Menlo Park, California. 
gravel-containing sands, the gravel correction construct, which lowers laboratory-measured $\mathrm{K}_{\mathrm{d}}$ values as a function of gravel content, has a significant effect on the migration velocity of most sorbing contaminants.

\subsection{Moisture Dependency of $K_{d}$ Values}

The moisture dependency of $K_{d}$ values has been evaluated (Lindenmeier et al. 1995; Kaplan et al. 1996; Gamerdinger et al. 1998, 2001). Based on our findings to date, as well as on the literature, our belief on this subject is that there is a slight decrease in $\mathrm{K}_{d}$ values for $\mathrm{U}(\mathrm{VI})$ and other likely contaminants as the moisture content in a system decreases. Supporting this contention is that four of the five sediments tested to date showed this trend. The sediment that did not show this trend had only two $\mathrm{K}_{\mathrm{d}}$ data points, one from a saturated system and the other from an unsaturated system (Kaplan et al. 1996). This decrease in $\mathrm{K}_{\mathrm{d}}$ for $\mathrm{U}(\mathrm{VI})$ as percent saturation decreased may be attributed to the fact that, as the degree of saturation decreases, solutes come into contact with fewer exchange sites. But with more contact time between the vadose zone sediments and the pore water, diffusion processes may allow the contaminants to interact with sediment adsorption sites that are hidden in dead-end pore spaces. The dead-end pore spaces may be created during the laboratory flow-through column experiments performed at unsaturated moisture contents, although they also occur in nature as determined in some field studies. That is, the slight dependency [decrease in $\mathrm{K}_{\mathrm{d}}$ for $\mathrm{U}(\mathrm{VI})$ ] of $\mathrm{K}_{\mathrm{d}}$ as percent saturation decreased may be caused by a physical process that will be less important in the field than a chemical process. An alternative explanation is that higher ionic-strength fluid exists in the double layer of partially saturated sediments, leading to weaker sorption. This latter explanation is less likely because the double layer around particle surfaces reaches only nanometers into the water, whereas the uniform film thickness of pore fluid around unsaturated Hanford Site sediments is estimated to be several micrometers (see Appendix B for a brief discussion). For the 2005 IDF PA, we will ignore the $\mathrm{K}_{d}$ dependency on moisture content and use the $\mathrm{K}_{\mathrm{d}}$ values measured in traditional saturated tests. If the flow models used in future performance assessment calculations (beyond the 2005 IDF PA) are capable of modeling the mobile-immobile water concepts presented in van Genuchten (1981), the effect of moisture content on the retardation factor can be accommodated without altering the $\mathrm{K}_{\mathrm{d}}$ value. Consequently, all $\mathrm{K}_{\mathrm{d}}$ estimates used in future calculations for the vadose zone may be slightly lower than those derived from traditional tests conducted in saturated systems.

\subsection{Colloid-Facilitated Transport of Contaminants}

Contaminant transport is traditionally modeled as a two-phase system: a mobile aqueous phase and an immobile solid phase. Over the last 15 years, we have become increasing aware of a third phase, a mobile solid phase. This mobile solid phase, mobile colloids, consists of organic and/or inorganic submicron particles that move with groundwater flow. When radionuclides are associated with colloids, the net effect is that radionuclides can move faster through the system than would be predicted on the basis of reversible sorption. It is not known whether colloids in the subsurface environment of the Hanford Site enhance contaminant transport. Furthermore, it is not known whether mobile colloids in a plume emanating from the IDF will have significant effects on contaminant transport rates.

Mobile colloid formation is commonly described as a three-step process: genesis, stabilization, and transport. Colloid genesis describes how the submicron particles are formed in groundwater. Stabilization describes how the colloids are brought into suspension, which is a function of the colloid and 
groundwater composition and water flow forces. Transport describes how the suspended colloids move through the porous media or are retained by physical forces such as diffusion, straining, gravitational settling, or physicochemical attraction to the matrix.

Regarding the first step, colloid genesis, there is little doubt that radionuclide-bearing colloids will be generated at the IDF site. Ramsay (1988) presented strong evidence for the existence of colloid particles in glass and cement leachates and provided an in-depth review of the various types of colloids that may exist (e.g., glass fragments, precipitation products, geological materials, secondary phases formed from glass leachate). Based on experiments using Hanford Site groundwater and colloids, it is less likely that colloids would remain suspended in glass leachate, cement leachate, or Hanford groundwater (McGraw and Kaplan 1997). The ionic strengths of these solutions greatly exceed the critical flocculation concentration (the minimum electrolyte concentration to induce colloid flocculation) of most particles. Even in uncontaminated Hanford groundwater, where the ionic strength would be at its lowest, the critical flocculation concentration is likely exceeded by 300 to $600 \%$ depending on the type of colloid in suspension. Hence, at this time we assume that colloid-facilitated transport of contaminants below the IDF facility is not a significant risk-driving process because the Hanford vadose zone sediment-pore water environment is not conducive to stabilizing colloids in the transporting fluid. Based on this logic, we will not consider colloid-facilitated transport an important process in the IDF PA until there is compelling evidence that our assessment is flawed. A recent Hanford tank leak-relevant colloid study also shows that ${ }^{137} \mathrm{Cs}$ transport through Hanford sediments via colloids is not likely to be significant from a long-term risk perspective (Zhuang et al. 2003). 


\subsection{Geochemistry of Contaminants of Concern}

This chapter provides a brief description of the geochemistry of several key contaminants of concern that have been identified by subsurface transport simulations as presenting the greatest health risks for the groundwater pathway. In the 2001 version of the ILAW PA, Mann et al. (2001) discuss the predicted radionuclide fluxes for the groundwater pathway, and identified ${ }^{99} \mathrm{Tc},{ }^{129} \mathrm{I},{ }^{237} \mathrm{~Np}$, and uranium isotopes as key radionuclides of concern for this pathway. The expected radionuclide inventories to be used for 2005 IDF PA are discussed in Puigh (2004). The review of ${ }^{79} \mathrm{Se}$ was retained from the previous version of this document (Kaplan and Serne 2000) because it had been identified as a possible radionuclide of concern in an earlier ILAW PA (Mann et al. 1998). Sections on the geochemistry of chromium and nitrate have been added because of their importance as possible contaminants of concern for the Hanford Site in general. Emphasis is placed on describing the chemical processes relevant to the behavior of these contaminants in the IDF's unsaturated zone, which is coarse sand-textured alkaline sediment with low natural organic matter concentrations. Geochemical information relevant to other environments, such as reducing environments, is also provided to address possible near-field systems and/or possible localized stagnant silt/mud regions in the upper unconfined aquifer.

To describe these processes, computer modeling methods were used to calculate equilibrium thermodynamic principles, the distributions of predominant aqueous species, and potential solubility controls for the environmentally important oxidation states of each of the contaminants of concern. The results of these speciation and solubility calculations are presented as a series of Eh-pH (or Pourbaix) diagrams. The diagrams are presented to highlight important general aspects of the aqueous speciation, redox, and solubility behavior of chromium, iodine, nitrogen (as nitrate/nitrite/ammonia), neptunium, selenium, technetium, and uranium. The Eh-pH diagrams were calculated using The Geochemist's Workbench ${ }^{\circledR}$ (Version 4.0) software and the expanded thermodynamic database file thermo.com.V8.R6+.dat provided with it. The theory behind the calculation of Eh-pH diagrams is discussed by Garrels and Christ (1965), Langmuir (1997), Nordstrom and Munoz (1985), and others. Lawrence Livermore National Laboratory (LLNL) developed the thermodynamic database file to use with the EQ3/6 geochemical model. This file does include the thermodynamic values for the uranium species listed in the critical review by Grenthe et al. (1992) but predates publication of the critical reviews of thermodynamic values for technetium and neptunium species by Rard et al. (1999) and Lemire et al. (2001), respectively, and the update to these earlier critical reviews by Guillaumont et al. (2003). Unless otherwise noted, the Eh-pH diagrams were calculated at $25^{\circ} \mathrm{C}$ for a contaminant concentration of $1 \times 10^{-8} \mathrm{~mol} / \mathrm{L}$ and total carbonate concentrations of $1 \times 10^{-3} \mathrm{~mol} / \mathrm{L}$, which were arbitrarily selected to help demonstrate the importance of aqueous complexation, redox, and possible solubility reactions for each contaminant.

Two Eh-pH diagrams were calculated for each element. The first diagram for each set shows only the dominant aqueous species and was calculated suppressing precipitation of any solids that may have been thermodynamically oversaturated for the specified conditions. The second Eh-pH diagram was calculated without this constraint and shows Eh-pH regions where the solubility of the indicated solid(s) is exceeded and thus could precipitate. Each diagram contains two dashed black lines at (Eh $1.2 \mathrm{~V}-\mathrm{pH} 0$ to Eh $0.4 \mathrm{~V}-$ $\mathrm{pH} 14)$ and (Eh $0.0 \mathrm{~V}-\mathrm{pH} 0$ to $\mathrm{Eh}-0.8 \mathrm{~V}-\mathrm{pH} 14)$ that represent the Eh-pH boundaries for the breakdown of water to its gaseous components at equilibrium at $25 \mathrm{EC}$ and $1 \mathrm{~atm}$ pressure. The redox conditions for essentially all environmental systems occur in the region between these water stability limits. 
The Eh-pH conditions of primary interest to the 2005 IDF PA are oxidizing conditions at $\mathrm{pH}$ values greater than approximately 7. A pH in the range from 7.5 to 8.5 is expected for vadose zone pore fluid and groundwater that are not chemically affected by leachates from the IDF disposal cells. Higher $\mathrm{pH}$ values of approximately 9.5 and as high as 12.5 are expected for fluids that are chemically influenced by glass and cement leachates, respectively (see Section 4).

\subsection{Chromium}

The geochemical behavior of chromium has been reviewed by Rai et al. (1988), Palmer and Wittbrodt (1991), Richard and Bourg (1991), and Palmer and Puls (1994). Ball and Nordstrom (1998) present a critical review of the thermodynamic properties for chromium metal and its aqueous ions, hydrolysis species, oxides, and hydroxides.

\subsubsection{Oxidation States and Aqueous Speciation}

Chromium exists in the $+2,+3$, and +6 oxidation states in water, of which only the +3 and +6 states are found in natural environments. Chromium(VI) exists only under oxidizing conditions, whereas $\mathrm{Cr}(\mathrm{III})$ exists over a wide range of $\mathrm{pH}$ and Eh conditions. Chromium(VI) tends to be soluble, forms anionic or neutral dissolved species, and can be very mobile (Nriagu and Nieboer 1988). In contrast, $\mathrm{Cr}(\mathrm{III})$ tends to precipitate, form cationic dissolved species, and become immobile in saturated sediments under moderately alkaline to slightly acidic conditions.

The reduction of $\mathrm{Cr}(\mathrm{VI})$ to $\mathrm{Cr}(\mathrm{III})$ by abiotic and biotic processes has been the subject of extensive studies recently because of its significant effect on the mobility of chromium in waste streams, vadose zones, sediments, and groundwaters. These reaction processes are the basis for certain remediation technologies such as permeable barriers composed of zero-valent iron particles (i.e., as metallic iron) (e.g., Cantrell et al. 1995) or sodium-dithionite reduced soils (e.g., Fruchter et al. 2000), which are being tested for immobilization of groundwater contaminants. Microbial reduction of $\mathrm{Cr}(\mathrm{VI})$ also has been suggested as a potential mechanism for removal of chromium from contaminated groundwaters and waste streams.

Chromium(VI) is a strong oxidant and is rapidly reduced in the presence of such common electron donors as aqueous $\mathrm{Fe}(\mathrm{II})$, ferrous [Fe(II)] iron minerals, reduced sulfur, microbes, and organic matter (Bartlett and Kimble 1976; Nakayama et al. 1981). Studies indicate that $\mathrm{Cr}(\mathrm{VI})$ can be reduced to $\mathrm{Cr}(\mathrm{III})$ by $\mathrm{Fe}(\mathrm{II})$ derived from magnetite $\left(\mathrm{Fe}_{3} \mathrm{O}_{4}\right)$ and ilmenite $\left(\mathrm{FeTiO}_{3}\right)$ (White and Hochella 1989), hematite $\left(\mathrm{Fe}_{2} \mathrm{O}_{3}\right)$ (Eary and Rai 1989), and pyrite $\left(\mathrm{FeS}_{2}\right)$ (Blowes and Ptacek 1992). Eary and Rai (1989) attributed the reduction of $\mathrm{Cr}(\mathrm{VI})$ to $\mathrm{Cr}(\mathrm{III})$ by hematite $\left(\mathrm{Fe}_{2} \mathrm{O}_{3}\right)$ to hematite containing trace quantities of $\mathrm{Fe}(\mathrm{II})$.

The reduction of $\mathrm{Cr}(\mathrm{VI})$ by $\mathrm{Fe}(\mathrm{II})$ is very rapid. The reaction can go to completion in a matter of minutes (Eary and Rai 1989). The rate of reduction of $\mathrm{Cr}(\mathrm{VI})$ increases with decreasing $\mathrm{pH}$ and increasing initial Cr(VI) and reductant concentrations (Palmer and Puls 1994). Eary and Rai (1989) determined that this reaction does not appear to be slowed by the presence of dissolved oxygen. Dissolved oxygen and manganese-dioxide minerals (e.g., pyrolusite $\left[\beta-\mathrm{MnO}_{2}\right]$ ) are the only two constituents in the environment known to oxidize Cr(III). Eary and Rai (1987) reported that the rate of Cr(III) oxidation was much greater in the presence of manganese-dioxide minerals than dissolved oxygen. 
The oxidation of $\mathrm{Cr}$ (III) by dissolved $\mathrm{O}_{2}$ and manganese oxides has been verified in laboratory experiments. The rate of oxidation of $\mathrm{Cr}(\mathrm{III})$ by $\mathrm{O}_{2}$ is very slow (Van der Weijden and Reith 1982; Eary and Rai 1987), whereas oxidation by manganese oxides, such as manganite ( $\gamma-\mathrm{MnOOH})$, has been determined experimentally to be fast (Johnson and Xyla 1991). Studies by Johnson and Xyla (1991) indicated that the $\mathrm{Cr}$ (III) oxidation by manganite consisted of an adsorption step, three separate electron transfer steps, and a desorption step. Because the reaction was found to be independent of $\mathrm{pH}$ and ionic strength, Johnson and Xyla (1991) suggested that a reaction at the manganite surface is the rate limiting step for $\mathrm{Cr}(\mathrm{III})$ oxidation via this reaction process.

Figure 3.1 is an Eh-pH diagram that shows the dominant aqueous species of chromium predicted to be present at $25^{\circ} \mathrm{C}$ and a total concentration of $1 \times 10^{-8} \mathrm{~mol} / \mathrm{L}$ dissolved chromium. Chromium(VI) has relatively simple hydrolysis behavior, forming primarily anionic species including $\mathrm{HCrO}_{4}{ }^{-}$(bichromate) and $\mathrm{CrO}_{4}{ }^{2-}$ (chromate) at $\mathrm{pH}$ values less and greater than 6.5, respectively, and $\mathrm{Cr}_{2} \mathrm{O}_{7}{ }^{2-}$ (dichromate) at higher concentrations of dissolved chromium (Baes and Mesmer 1976; Palmer and Wittbrodt 1991; Richard and Bourg 1991). Chromium(VI) as chromate $\left(\mathrm{CrO}_{4}{ }^{2-}\right)$ is likely to be the dominant chromium species in the Hanford vadose zone and upper unconfined aquifer because its domain of predominance extends over a wide range of $\mathrm{pH}$ and $\mathrm{Eh}$ conditions that are appropriate for the vadose zone and upper unconfined aquifer (Figure 3.1). Chromium(III) exists predominantly as $\mathrm{Cr}^{3+}$ below $\mathrm{pH} 4$ in the $\mathrm{Cr}$ (III)$\mathrm{H}_{2} \mathrm{O}$ system. With increasing $\mathrm{pH}$, hydrolysis of $\mathrm{Cr}^{3+}$ yields $\mathrm{CrOH}^{2+}, \mathrm{Cr}(\mathrm{OH})_{2}{ }^{+}, \mathrm{Cr}(\mathrm{OH})_{3}{ }^{0}(\mathrm{aq})$, and $\mathrm{Cr}(\mathrm{OH})_{4}^{-}$. At higher chromium concentrations, polynuclear species such as $\mathrm{Cr}_{2}(\mathrm{OH})_{2}{ }^{4+}$ and $\mathrm{Cr}_{3}(\mathrm{OH})_{4}{ }^{5+}$ can form slowly at $25^{\circ} \mathrm{C}$ (Baes and Mesmer 1976). Chromium(III) complexes with dissolved ligands such as fluoride, ammonia, and cyanide (Baes and Mesmer 1976). Figure 3.1 is similar to one in Ball

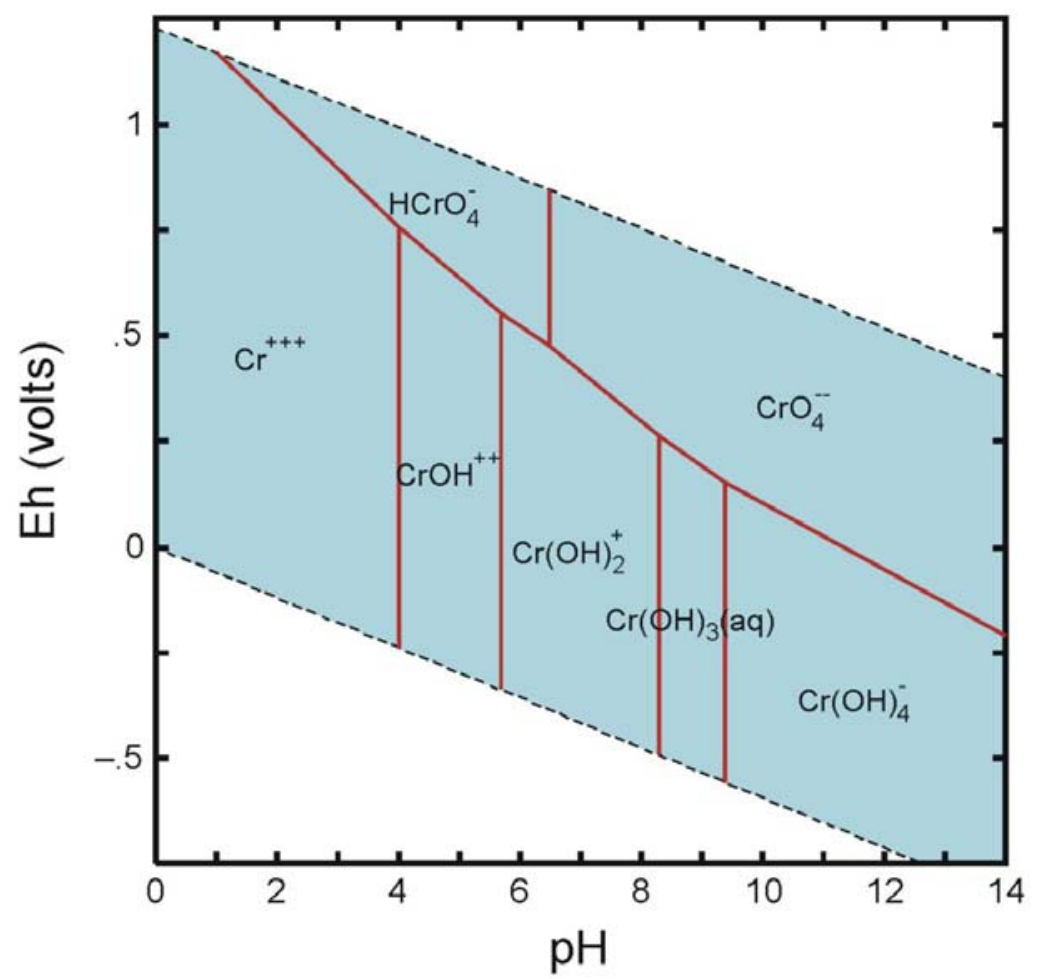

Figure 3.1. $\quad$ Eh-pH Diagram Showing Dominant Aqueous Species of Chromium. (Diagram was calculated at a total concentration of $1 \times 10^{-8} \mathrm{~mol} / \mathrm{L}$ dissolved chromium at $25^{\circ} \mathrm{C}$.) 
and Nordstrom (1998), but Ball and Nordstrom's figure shows pH stability ranges for the aqueous species $\mathrm{Cr}(\mathrm{OH})_{2}{ }^{+}$and $\mathrm{Cr}(\mathrm{OH})_{3}{ }^{0}(\mathrm{aq})$ that are smaller and larger, respectively, than those in Figure 3.1.

\subsubsection{Precipitation and Coprecipitation}

The concentrations of dissolved $\mathrm{Cr}(\mathrm{VI})$ in the vadose zone and unconfined aquifer under the IDF are not expected to be affected by the precipitation of $\mathrm{Cr}(\mathrm{VI})$-containing mineral phases. Though several $\mathrm{Cr}(\mathrm{VI})$-containing minerals are known, they only occur at sites highly contaminated with chromium; e.g., Palmer and Wittbrodt (1991) identified $\mathrm{PbCrO}_{4}$ (crocoite), $\mathrm{PbCrO}_{4} \mathrm{AH}_{2} \mathrm{O}$ (iranite), and $\mathrm{K}_{2} \mathrm{CrO}_{4}$ (tarapacite) in chromium sludge from a plating facility. Palmer and Wittbrodt (1990) also reported that $\mathrm{BaCrO}_{4}$ formed a complete solid solution with $\mathrm{BaSO}_{4}$. They concluded that these solid solutions can be a major impediment to successful remediation of chromium-contaminated sites by pump-and-treat technologies.

Baron et al. (1996) have identified two iron-chromate precipitates, $\mathrm{KFe}_{3}\left(\mathrm{CrO}_{4}\right)_{2}(\mathrm{OH})_{6}$ and $\mathrm{KFe}\left(\mathrm{CrO}_{4}\right)_{2} \cdot 2 \mathrm{H}_{2} \mathrm{O}$, in a soil contaminated by chrome plating solutions. Powder X-ray diffraction analyses by Baron et al. (1996) showed that most of the $\mathrm{Cr}(\mathrm{VI})$ in the contaminated soil is present at $\mathrm{KFe}_{3}\left(\mathrm{CrO}_{4}\right)_{2}(\mathrm{OH})_{6}$, which is a chromate analog of the sulfate mineral jarosite. The transformation reaction between these two precipitates shows that $\mathrm{KFe}\left(\mathrm{CrO}_{4}\right)_{2} \cdot 2 \mathrm{H}_{2} \mathrm{O}$ will form in more acidic, potassium-, and chromate-rich conditions relative to $\mathrm{KFe}_{3}\left(\mathrm{CrO}_{4}\right)_{2}(\mathrm{OH})_{6}$ (Baron et al. 1996). Solubility and dissolution rate experiments by Baron and Palmer (1996) indicate that $\mathrm{KFe}_{3}\left(\mathrm{CrO}_{4}\right)_{2}(\mathrm{OH})_{6}$ is stable over a wide range of conditions and could form in a $\mathrm{Cr}(\mathrm{VI})$-contaminated aquifer.

In some sediment systems under moderately and highly reducing conditions, the concentration of dissolved chromium may be controlled by the precipitation of $\mathrm{Cr}$ (III) solids. Because $\mathrm{Cr}$ (III) tends to precipitate, it is considered relatively immobile under moderately alkaline to slightly acidic conditions. Figure 3.2 shows the Eh-pH region ( $\tan$ area) that calculates as oversaturated with respect to the minerals eskolaite $\left(\mathrm{Cr}_{2} \mathrm{O}_{3}\right)$ and brezinaite $\left(\mathrm{Cr}_{3} \mathrm{~S}_{4}\right)$ for an aqueous solution containing a total concentration of dissolved chromium of $10^{-8} \mathrm{~mol} / \mathrm{L}$. Several investigators have presented evidence suggesting the formation of solubility-controlling solids of Cr(III) in sediments. Hem (1977), for example, reported that the total chromium concentration in groundwater beneath Paradise Valley, Arizona, was close to the solubility of $\mathrm{Cr}_{2} \mathrm{O}_{3}$. Rai et al. (1984) concluded that most $\mathrm{Cr}$ (III) solubility-controlling solids in nature are either $\mathrm{Cr}(\mathrm{OH})_{3}$ or $\mathrm{Cr}(\mathrm{III})$ coprecipitated with iron oxides. Their conclusion was supported by three observations: 1) the thermodynamic treatment of the data where the solubility of chromite $\left(\mathrm{FeCr}_{2} \mathrm{O}_{4}\right)$ is predicted to be the lowest among the chromium minerals for which data are available (Hem 1977), 2) the similarity of $\mathrm{Cr}(\mathrm{III})$ and $\mathrm{Fe}(\mathrm{III})$ ionic radii, and 3) the observations that aqueous $\mathrm{Cr}(\mathrm{III})$ is removed by $\mathrm{Fe}(\mathrm{OH})_{3}$ precipitation and that chromium during weathering is found to associate with ferric-rich materials (Nakayama et al. 1981). Sass and Rai (1987) determined that Cr(III) can precipitate with Fe(III) to form a solid solution with the general composition $\mathrm{Cr}_{x} \mathrm{Fe}_{1-\mathrm{x}}(\mathrm{OH})_{3}$ when the $\mathrm{pH}$ is greater than 4 . The solubility of chromium in this solid solution decreases as the mole fraction of Fe(III) increases (Sass and Rai 1987). 


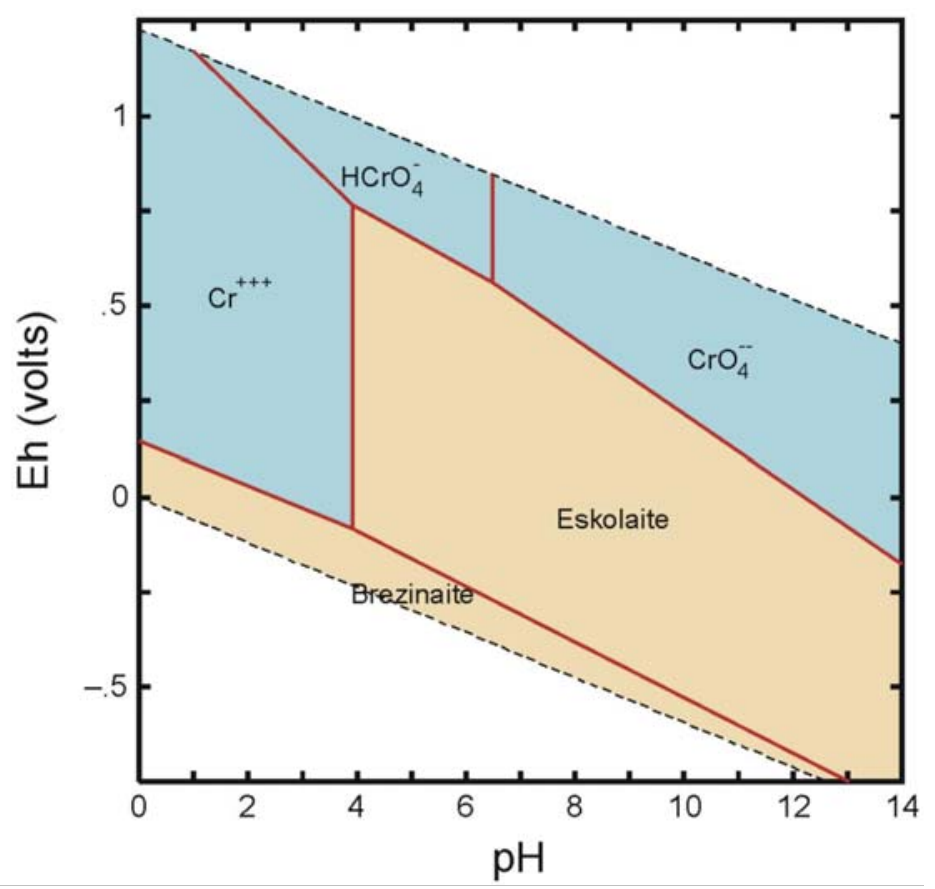

Figure 3.2. Stability Diagram Showing Eh-pH Region ( $\tan )$ that Calculates as Oversaturated with Respect to the Solubility of Cr(III) Solids. (Diagram was calculated at total concentration of $1 \times 10^{-8} \mathrm{~mol} / \mathrm{L}$ dissolved neptunium at $25^{\circ} \mathrm{C}$.)

\subsubsection{Sorption}

EPA (1999b) provides a detailed review of the available adsorption information for $\mathrm{Cr}(\mathrm{VI})$. Because $\mathrm{Cr}(\mathrm{VI})$ exists primarily as the anion $\mathrm{CrO}_{4}{ }^{2-}$ in most oxic sediment systems, the extent to which $\mathrm{Cr}(\mathrm{VI})$ sorbs to sediments is appreciably less than that of $\mathrm{Cr}$ (III). As an anion, $\mathrm{Cr}(\mathrm{VI})$ does not readily adsorb in sediments to any significant extent under most geochemical conditions, and therefore is considered very mobile in aqueous systems.

Most information on $\mathrm{Cr}(\mathrm{VI})$ adsorption comes from studies with pure mineral phases (Leckie et al. 1980; Davis and Leckie 1980; Griffin et al. 1977). These studies suggest that $\mathrm{Cr}(\mathrm{VI})$ adsorbs strongly to gibbsite $\left(\alpha-\mathrm{Al}_{2} \mathrm{O}_{3}\right)$ and amorphous iron oxide $\left[\mathrm{Fe}_{2} \mathrm{O}_{3} \cdot \mathrm{H} 2 \mathrm{O}(\mathrm{am})\right]$ at low to medium $\mathrm{pH}$ values (i.e., $\mathrm{pH} 2$ to 7$)$ and adsorbs weakly to silica $\left(\mathrm{SiO}_{2}\right)$ at all but very low $\mathrm{pH}$. These results can be explained by considering the isoelectric points of these minerals. When the $\mathrm{pH}$ of the system is greater than the isoelectric point, the mineral has a net negative charge. When the $\mathrm{pH}$ is below the isoelectric point, the mineral has a net positive charge. Hence, anion adsorption, such as that for chromate, iodide, nitrate, selenate, and pertechnetate, generally increases as the $\mathrm{pH}$ becomes progressively lower than the isoelectric point.

The presence of competing and, less commonly, complexing ions may significantly alter chromate adsorption. Although sulfate is adsorbed less strongly on $\mathrm{Fe}_{2} \mathrm{O}_{3} \cdot \mathrm{H}_{2} \mathrm{O}$ (am) than $\mathrm{CrO}_{4}{ }^{2-}$, sulfate may compete for adsorption sites when present in higher concentrations (Leckie et al. 1980). Phosphate exhibits a greater competitive effect on $\mathrm{CrO}_{4}{ }^{2-}$ adsorption (MacNaughton 1977), reducing sorption by around $50 \%$ when present at equal normality. Information on effects of complexing ions on $\mathrm{Cr}(\mathrm{VI})$ 
sorption is almost nonexistent, though adsorption of ion pairs [e.g., $\mathrm{CaCrO}_{4}{ }^{0}(\mathrm{aq})$ and $\mathrm{KHCrO}_{4}{ }^{0}(\mathrm{aq})$ ] is suggested as one possible mechanism for removal of $\mathrm{Cr}(\mathrm{VI})$ by $\mathrm{Fe}_{2} \mathrm{O}_{3} \cdot \mathrm{H}_{2} \mathrm{O}$ (am) (Leckie et al. 1980).

Adsorption of $\mathrm{Cr}$ (III) to soils has received only a nominal amount of research attention, possibly because sorption of $\mathrm{Cr}$ (III) by sediment is commonly attributed to precipitation processes for $\mathrm{Cr}$ (III)containing solids. Chromium(III) rapidly hydrolyzes and precipitates as the hydroxide $\mathrm{Cr}(\mathrm{OH})_{3}$ and/or coprecipitates with $\mathrm{Fe}(\mathrm{OH})_{3}$ (Hem 1977; Artiola and Fuller 1979). Limited studies infer that $\mathrm{Cr}(\mathrm{III})$, like other +3 cationic metals, is strongly and specifically absorbed by soil iron and manganese oxides (Korte et al. 1976).

Cantrell et al. (2003) compiled in a single source $K_{d}$ values measured with Hanford sediment for radionuclides and contaminants of concern that have potential environmental effects in the vadose zone and groundwater at the Hanford Site. Cantrell et al. (2003, Table 10) list the $\mathrm{K}_{\mathrm{d}}$ values determined for $\mathrm{Cr}(\mathrm{VI})$ with Hanford sediment; they found only a limited number of studies of $\mathrm{Cr}(\mathrm{VI})$ adsorption on Hanford sediment. The measured $\mathrm{K}_{\mathrm{d}}$ values for $\mathrm{Cr}(\mathrm{VI})$ on Hanford sediment range from 0 to 1, with typical values being zero or close to zero, and based on these results concluded that adsorption of $\mathrm{Cr}(\mathrm{VI})$ is very low to nonexistent under normal Hanford groundwater conditions unless conditions are acidic. The adsorption of $\mathrm{Cr}(\mathrm{VI})$ is expected to increase with decreasing $\mathrm{pH}$ because dissolved $\mathrm{Cr}(\mathrm{VI})$ exists as an anionic species. Cantrell et al. noted that the available data indicate the $\mathrm{K}_{\mathrm{d}}$ values for $\mathrm{Cr}(\mathrm{VI})$ adsorption to Hanford sediment under acidic conditions increase significantly with increasing equilibration time. It is speculated that this may be caused by the reduction of dissolved $\mathrm{Cr}$ (VI) to $\mathrm{Cr}$ (III) by the slow release of Fe(II) from basaltic minerals in the Hanford sediment (Cantrell et al. 2003). This reduction in turn results in the precipitation of solid $\mathrm{Cr}(\mathrm{OH})_{3}$ and the apparently high $\mathrm{K}_{\mathrm{d}}$ values.

\subsection{Iodine}

There are 24 known isotopes of iodine, and 18 of them have half-lives of less than 1 day. The only stable isotope is ${ }^{127} \mathrm{I}$. Its average natural abundance in geologic materials is $5 \mathrm{mg} / \mathrm{kg}$ ( $\mathrm{Gu}$ and Schulz 1991 ) and its concentration in uncontaminated surface waters is typically less than $1 \mathrm{mg} / \mathrm{L}$ (Stumm and Morgan 1981). The isotope of concern for long-term disposal at the Hanford Site is ${ }^{129} \mathrm{I}$, which has a halflife of $1.57 \times 10^{7}$ years (Tuli 2004). The environmental behavior of iodine has been reviewed by Lieser and Steinkopff (1989), Whitehead (1984), Coughtrey et al. (1983), and Ames and Rai (1978).

\subsubsection{Oxidation States and Aqueous Speciation}

Although the environmental chemistry of iodine is normally assumed to be simple and well known, recent studies suggest that the fate and mobility of iodine in environmental systems may be more complex than expected due to the multiple redox states that may exist under oxidizing conditions. The $-1,+5$, and molecular $\mathrm{I}_{2}\left[\mathrm{I}_{2}{ }^{0}(\mathrm{aq})\right]$ oxidation states are those most relevant for iodine in environmental systems. Iodine usually exists in fresh water in the -1 oxidation state as iodide $\left(\mathrm{I}^{-}\right)$(Whitehead 1984). In alkaline and marine environments, iodine usually exists in the +5 oxidation state as iodate $\left(\mathrm{IO}_{3}^{-}\right)$(Whitehead 1984). Iodide $\left(\mathrm{I}^{-}\right)$and $\mathrm{IO}_{3}{ }^{-}$were the most commonly detected species in rainwater collected after the Chernobyl accident (Muramatsu et al. 1990). The other oxidation states of iodine, such as +1 and +7 , are known but are unstable in natural systems (Lieser and Steinkopff 1989). Figure 3.3 is an Eh-pH diagram that shows the dominant aqueous species of iodine predicted to be present at $25 \mathrm{EC}$ and a total concentration of $1 \times 10^{-8} \mathrm{~mol} / \mathrm{L}$ dissolved iodine. Iodide is likely to be the dominant iodine species in the Hanford Site's 


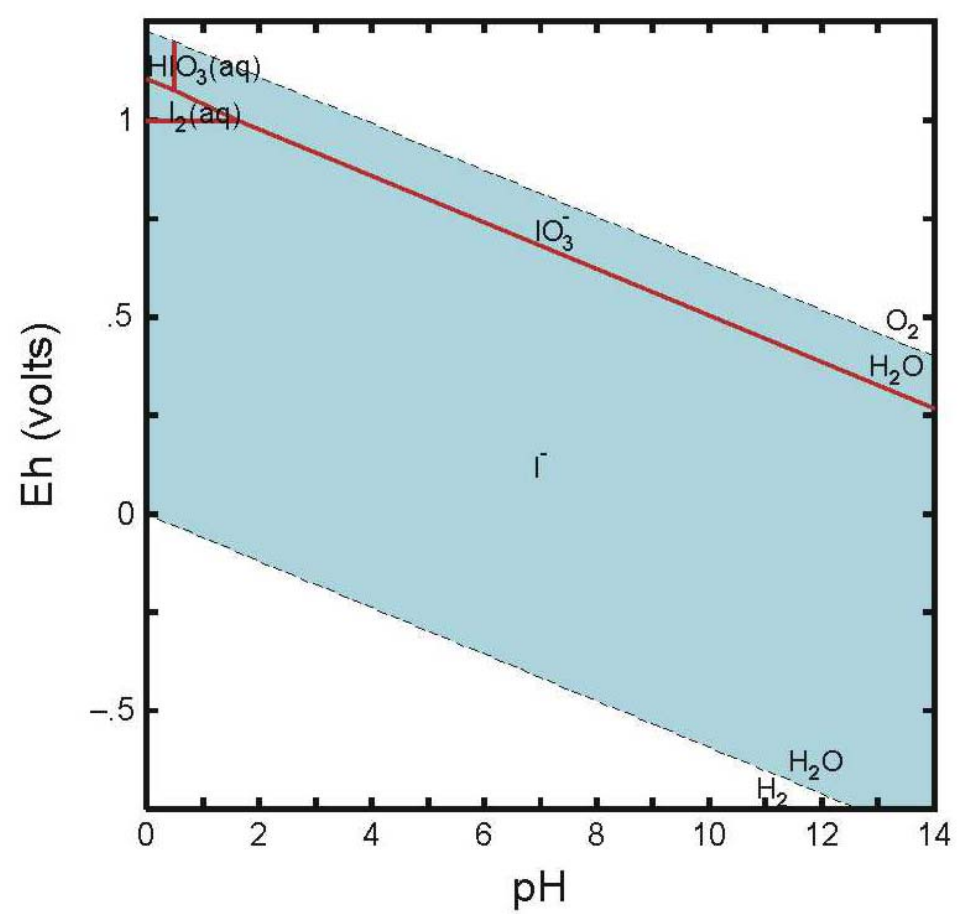

Figure 3.3. Eh-pH Diagram Showing Dominant Aqueous Species of Iodine. (Diagram calculated at a total concentration of $1 \times 10^{-8} \mathrm{~mol} / \mathrm{L}$ dissolved iodine at $25^{\circ} \mathrm{C}$.)

upper unconfined aquifer because its domain of predominance extends almost over the entire $\mathrm{pH}$ and Eh range for the stability of water (Figure 3.3). Under oxidizing acidic conditions, molecular $\mathrm{I}_{2}{ }^{0}$ (aq) may form from the reduction of $\mathrm{IO}_{3}{ }^{-}$or the oxidation of $\mathrm{I}^{-}$. Oxidation of $\mathrm{I}_{2}{ }^{0}(\mathrm{aq})$ to produce $\mathrm{IO}_{3}{ }^{-}$, the second most abundant form of iodine in aqueous systems, is easily accomplished in basic solution by the reaction (Cotton and Wilkinson 1972):

$$
3 \mathrm{I}_{2}{ }^{0}(\mathrm{aq})+6 \mathrm{OH}^{-}=5 \mathrm{I}^{-}+\mathrm{IO}_{3}^{-}+3 \mathrm{H}_{2} \mathrm{O}
$$

Thus, the $\mathrm{IO}_{3}{ }^{-}$form of iodine is likely dominant in the well-oxidized, high-pH systems that may exist in the near field of the IDF site. Iodide and $\mathrm{IO}_{3}{ }^{-}$tend to exist as free ions, but the complexes they form are generally the most soluble of all halide complexes.

The volatilization of iodine from sediment and soil to the atmosphere may occur as a result of both chemical and microbiological processes (Whitehead 1984). The chemical processes generally result in molecular iodine or hydrogen iodide, and the microbiological processes yield organic compounds such as methyl iodide. Methyl iodide is not strongly retained by soil components and is only slightly soluble in water (Whitehead 1984).

\subsubsection{Precipitation and Coprecipitation}

Precipitation of $\mathrm{I}^{-}$compounds is not likely to be a dominant reaction path for $\mathrm{I}^{-}$in the glass leachate. Iodide, in comparison with the other halides, forms especially weak complexes with metal ions as a result of its large size (0.22-nm ionic radius) (Langmuir 1979). The metals with which $\mathrm{I}^{-}$and $\mathrm{IO}_{3}^{-}$form sparingly soluble compounds, such as silver, barium, mercury, lead, and palladium (Pourbaix 1966), exist in 
nature at very low concentrations. The low concentrations of iodine in the contaminant plume likely will exist either as free species or as highly soluble complex species.

Results recently published by Mattigod et al. ${ }^{(a)}(2002,2003)$ from waste glass weathering studies conducted in support of the ILAW/IDF PA suggest that under oxic conditions, secondary products that form from the weathering of ILAW waste glasses may incorporate small masses of anionic contaminants such as iodide $\left(\mathrm{I}^{-}\right)$, selenate $\left(\mathrm{SeO}_{4}{ }^{2-}\right)$, and pertechnetate $\left(\mathrm{TcO}_{4}{ }^{2-}\right)$ that may be resistant to remobilization. Mattigod et al. $(2002,2003)$ have conducted tests to identify the type of secondary minerals that form from the accelerated weathering of vitrified waste glasses and to evaluate potential incorporation of ${ }^{125} \mathrm{I}$ (as $\mathrm{I}^{-}$), ${ }^{75} \mathrm{Se}$ (as $\mathrm{SeO}_{4}{ }^{2-}$ ), and ${ }^{99} \mathrm{Tc}$ (as $\mathrm{TcO}_{4}{ }^{2-}$ ) from groundwater spiked with these radionuclides into the secondary mineral weathering products. Mattigod et al. identified the formation of zeolite minerals such as zeolite $\mathrm{P}$, analcime, and cancrinite as weathering products in static tests conducted at $160^{\circ} \mathrm{C}$ with two waste glasses (LAWBP1 and LAWA44) leached with uncontaminated Hanford groundwater. These glasses were selected because their compositions are expected to be similar to the actual glasses resulting from the vitrification of Hanford tank wastes. Mattigod et al. present details on the procedures and rationale and the compositions of materials and leachates used in their experiments. Mattigod also completed experiments with radionuclide-spiked groundwater and determined that $\sim 9$ to $18 \%$ of ${ }^{125} \mathrm{I}$, $\sim 6$ to $15 \%$ of ${ }^{75} \mathrm{Se}$, and $\sim 1$ to $12 \%$ of ${ }^{99} \mathrm{Tc}$ were sorbed in reaction products (i.e., secondary crystalline phases and hydrated gel layer) that formed from the leaching of waste glasses. Mattigod et al. (2003) $)^{(a)}$ found a similar amount of ${ }^{75}$ Se sorption $(\sim 8$ to $14 \%)$ but a slightly lower degree of ${ }^{125}$ I sorption $(\sim 12$ to $13 \%)$ when $1 \mathrm{M} \mathrm{NaOH}$ was used as the spiked leachate. Mattigod et al. $(2003,2004)$ then conducted a series of desorption tests to determine the extent of remobilization of the radionuclides that had been sorbed in the glass weathering products. Their results indicate that $\sim 55$ to $80 \%$ and $\sim 30$ to $90 \%$ of the sorbed ${ }^{125} \mathrm{I}, \sim 60$ to $70 \%$ and 30 to $90 \%$ of the sorbed ${ }^{75} \mathrm{Se}$, and $\sim 40$ to $58 \%$ and up to $67 \%$ of the sorbed ${ }^{99} \mathrm{Tc}$, respectively, in the weathered LAWBP1 and LAWA44 glasses did not easily desorb from the weathering glasses when contacted with groundwater-like solutions.

Until this apparent coprecipitation (or specific adsorption) of $\mathrm{I}^{-}, \mathrm{SeO}_{4}{ }^{2-}$, and $\mathrm{TcO}_{4}{ }^{2-}$ in waste glass weathering products is further quantified, this process is not included in transport calculations or the geochemical data package for the 2005 IDF PA. This will build a degree of conservatism into the calculations that could be removed if quantitative data for the extent of weathering product formation per unit mass of waste glass and the mass of coprecipitated contaminants of interest in these weathering products become available at a later date.

The precipitation of iodine-containing solids is not likely to be an important process in the far field due to the low concentrations of iodine in environmental systems and the high solubility of iodinecontaining minerals. Iodine can be found as a primary component in some rare, naturally occurring minerals that are associated with evaporite and brine deposits (Johnson 1994; Doner and Lynn 1977). Iodide is commonly present in substitution for other halogen elements, such as chloride and bromide, whereas $\mathrm{IO}_{3}{ }^{-}$typically is associated with sulfate- or nitrate-type minerals. Such minerals are expected to be highly soluble in sediments.

(a) Mattigod SV, RJ Serne, BP McGrail, VL LeGore, and KE Parker. 2004. "Sequestration of radionuclides $\left({ }^{125}\right.$ I, ${ }^{54} \mathrm{Se},{ }^{99} \mathrm{Tc}$ ) in secondary crystalline minerals resulting from chemical weathering of selected waste glasses." To be submitted to Radiochimica Acta. 


\subsubsection{Sorption}

Two types of reactions between anions and inorganic solids are recognized: specific and nonspecific adsorption. Specific adsorption refers to incorporation of anions as a ligand in the coordination shell of an adsorbent; nonspecific adsorption refers to adsorption of anions by simple coloumbic (electrostatic) interactions with positive charges. Iodine anions are believed to sorb primarily through nonspecific anion-exchange reactions on mineral surfaces (Gu and Schulz 1991) and specific adsorption on organic substances (Walters and Winchester 1971). Nonspecific sorption may occur at the localized positive charges that occur on 1) iron and aluminum oxide surfaces, 2) edges of alumino silicate clay surfaces where the oxygen atoms are not fully coordinated by aluminum or silicon atoms, and 3) amine and amino groups of organic substances. These positive charges, which increase with decreasing $\mathrm{pH}$, attract anions electrostatically. Whitehead (1973), for example, reported that sorption of I' by soils was associated with both soil organic matter and iron and aluminum oxides, with the oxides increasingly important under more acidic conditions. The maximum amounts sorbed by two surfaces occurred at $\mathrm{pH}$ 6.6. At this $\mathrm{pH}$, the amounts of $\mathrm{I}^{-}$sorbed were found to be closely related to the contents of organic matter but not to iron or aluminum oxides or clay. At $\mathrm{pH}$ values less than 5 , the removal of iron and aluminum resulted in a marked reduction in I' sorption. Whitehead (1974) further observed that freshly precipitated ferric and aluminum oxides sorbed substantial amounts of $\mathrm{I}^{-}$from solutions of $\mathrm{pH}$ less than 5.5, but the amount decreased to zero as the $\mathrm{pH}$ approached 7. Presumably, this trend reflects the presence of an increasing amount of positive charge (anion-exchange capacity) on the amphoteric oxide surfaces at lower $\mathrm{pH}$ levels.

An extensive review of iodine adsorption studies on sediments, soils, pure minerals, oxide phases, and crushed rock materials is presented in EPA (2004). Ticknor and Cho (1990) studied the interaction of $\mathrm{I}^{-}$and $\mathrm{IO}_{3}^{-}$over a $\mathrm{pH}$ range of 7.5 to 8.0 with a number of minerals including calcite, chlorite, epidote, goethite, gypsum, hematite, kaolinite, bentonite, muscovite, and quartz. No I- sorption was detected from any of the solutions on any of the minerals. Iodate was removed from solution to a somewhat greater extent than $\mathrm{I}^{-}$. Bentonite, calcite, gypsum, and muscovite adsorbed no $\mathrm{IO}_{3}^{-}$. Muramatsu et al. (1990) reported that neither $\mathrm{I}^{-}$nor $\mathrm{IO}_{3}{ }^{-}$sorbed to quartz sand. Based on these studies, it was concluded that the low $\mathrm{I}^{-}$and $\mathrm{IO}_{3}{ }^{-}$sorption was the result of the low anion-exchange capacities of the minerals at the high $\mathrm{pH}$ of the systems investigated. Recently, Kaplan et al. (1999, 2000a) showed that some naturally occurring 2:1 phyllosilicate minerals have the ability to sorb large amounts of $\mathrm{I}^{-} . \mathrm{K}_{\mathrm{d}}$ values of greater than $60 \mathrm{~mL} / \mathrm{g}$ were measured for illites. Illite generally accounts for approximately $20 \%$ of the clay fraction of Hanford Site sediments. Even at $\mathrm{pH}$ greater than $9, \mathrm{~K}_{\mathrm{d}}$ values for I' for these illites were greater than $20 \mathrm{~mL} / \mathrm{g}$. Subsurface Hanford sediment with a pH of 8 had $\mathrm{K}_{\mathrm{d}}$ values that average $3 \mathrm{~mL} / \mathrm{g}$ and ranged from 0.1 to $10 \mathrm{~mL} / \mathrm{g}$.

Um et al. (2004) completed a series of experiments to determine the linearity and reversibility of $\mathrm{I}^{-}$ adsorption onto Hanford formation sediment from an ILAW borehole (well name 299-E24-21; borehole number C3177) at the 200 East Area of the Hanford Site. The adsorption experiments were conducted using uncontaminated Hanford groundwater spiked with dissolved ${ }^{125} \mathrm{I}$ (as an analog tracer for ${ }^{129} \mathrm{I}$ ). Um et al. (2004) determined that $\mathrm{I}^{-}$adsorption was low $\left(\mathrm{K}_{\mathrm{d}}=0.2 \mathrm{~mL} / \mathrm{g}\right)$ at $\mathrm{pH} 7.5$ and could be represented by a linear isotherm up to a total concentration of $100 \mathrm{mg} / \mathrm{L}$ dissolved $\mathrm{I}^{-}$. The results of their desorption experiments indicate that up to $60 \%$ of adsorbed I- was readily desorbed after 14 days by I- free groundwater. Because $\mathrm{I}^{-}$adsorption was determined to be at least partially reversible, Um et al. (2004) proposed that the weak adsorption affinity would result in release of $\mathrm{I}^{-}$when uncontaminated waters contact

${ }^{129}$ I-contaminated sediments in the vadose zone and aquifer systems. 
Um and Serne ${ }^{(\mathrm{a})}$ completed a series of batch and column adsorption studies of ${ }^{99} \mathrm{Tc},{ }^{129} \mathrm{I},{ }^{79} \mathrm{Se}$, and ${ }^{90} \mathrm{Sr}$ on Hanford sediments collected from ILAW borehole \#2 (borehole number C3177) at the Hanford 200 East Area. The batch sorption experiments were conducted on this Hanford sediment using both uncontaminated Hanford groundwater and simulated glass leachates spiked with individual radionuclides. Um and Serne reported $\mathrm{K}_{\mathrm{d}}$ values for the adsorption of ${ }^{125} \mathrm{I}$, which was used as a surrogate for ${ }^{129} \mathrm{I}$, in Hanford groundwater on $\mathrm{C} 3177$ sediment from $45-, 110$-, and 215-ft depths below ground surface of $0.41 \pm 0.01$ (pH 7.8), $0.17 \pm 0.04$ (pH 7.8), and $0.25 \pm 0.02 \mathrm{~mL} / \mathrm{g}(\mathrm{pH} 7.7)$, respectively. The $\mathrm{K}_{\mathrm{d}}$ values for ${ }^{125} \mathrm{I}$ measured in simulated glass leachates for the equivalent sediment samples were $0.08 \pm 0.01(\mathrm{pH} 9.1)$, $0.16 \pm 0.08$ ( $\mathrm{pH}$ 9), and $0.04 \pm 0.01 \mathrm{~mL} / \mathrm{g}$ (pH 9), respectively. These measurements indicate low adsorption affinity for iodide on these sediments in both Hanford groundwater and simulated glass leachates. Um and Serne ${ }^{(a)}$ concluded that these adsorption data, especially the tests using simulated glass leachate, corroborate values obtained for sediments collected in the past from nearby locations and for generic aqueous solutions such as regional groundwater. Um and Serne also noted that the new results provide more technical defensibility for past performance assessment predictions that did not use site-specific sediments and/or leachates.

Kaplan et al. (2003) studied the influence of glass leachate on the hydraulic, physical, mineralogical, and sorptive properties of Hanford sediment. The ILAW generated from the Hanford Site will be disposed as a vitrified waste, and the leachate from this waste will have a high $\mathrm{pH}$ and high ionic strength. Kaplan et al. (2003) reacted $\mathrm{NaOH}$ solutions, a simplified surrogate for glass leachate, with quartz sand, a simplified surrogate for the Hanford subsurface sediment, and Warden soil, an actual Hanford sediment. Following contact with three concentrations of $\mathrm{NaOH}$ solutions, Kaplan determined the changes in hydraulic conductivity, porosity, moisture retention, mineralogy, aqueous chemistry, and soil radionuclide distribution coefficients for the contacted solids. Kaplan et al. (2003) observed significant changes in mineralogy under chemical conditions approaching the most caustic glass leachate conditions predicted in the near field of the ILAW/IDF site, as approximated by $0.3 \mathrm{M} \mathrm{NaOH}$. The clay minerals in the Hanford sediment underwent the greatest dissolution, thereby increasing the relative proportions of the more resistant minerals, e.g., quartz, feldspar, and calcite, in the remaining sediment. Kaplan et al. (2003) detected some reprecipitation of solids (mostly amorphous gels) after caustic contact with both solids. These precipitates increased the moisture retention in both sediments, likely because of water retained within the gel coatings. The hydraulic conductivities were slightly lower, but because of experimental artifacts, Kaplan et al. (2003) did not consider these reductions significant. Kaplan et al. (2003) concluded that there were no large differences in the hydraulic properties of the quartz sand or Warden silt loam soil after 192 days of contact with caustic fluids similar to glass leachate.

Kaplan et al. (2003) also completed batch sorption tests with Warden soil to measure the $\mathrm{K}_{\mathrm{d}}$ values for cesium, strontium, iodide, selenate, and pertechnetate in soils treated with caustic solutions for up to 360 days. Although some clay minerals, such as smectites and kaolinite, almost totally dissolved within a year of contact with $3 \mathrm{M} \mathrm{NaOH}$ (and, by inference, after longer time frames for $0.3 \mathrm{M} \mathrm{NaOH}$, a more realistic surrogate for ILAW glass leachate), other sorbing minerals such as illite and chlorite did not react appreciably. Kaplan et al. (2003) concluded that the net effect of glass leachate on the sorptive properties of Hanford sediments for the cited radionuclides of concern to the IDF is not expected to be significant. Specifically, little change was determined for the $K_{d}$ values for cesium, and the strontium $K_{d}$ values

(a) Um W and RJ Serne. 2004. "Sorption and Transport Behavior of Radionuclides in the Proposed Low-Level Radioactive Waste Disposal Facility at the Hanford Site, Washington." Submitted to Radiochimica Acta. 
increased significantly in the simulated glass leachates versus natural groundwater. Kaplan et al. proposed that increased strontium sorption and resulting high $\mathrm{K}_{\mathrm{d}}$ values were likely due to precipitation with $\mathrm{CaCO}_{3}$ at these high $\mathrm{pH}$ conditions. They did not detect any appreciable adsorption for iodide, selenate, or pertechnetate (i.e., $\mathrm{K}_{\mathrm{d}} \sim 0$ ) on Hanford sediment contacted with $\mathrm{NaOH}$ solutions. Some adsorption of selenate was measured in control tests using sodium perchlorate solutions at neutral $\mathrm{pH}$, but after caustic treatment and in high $\mathrm{pH}$ solutions, selenate sorption was determined to be nil. No iodide or pertechnetate technetium sorption was observed for the neutral-pH perchlorate or the high- $\mathrm{pH} \mathrm{NaOH}$ solutions as a function of time or ionic strength. Kaplan et al. (2003) concluded that adsorption reactions likely would not retard the migration of selenate, iodide, or pertechnetate from high $\mathrm{pH}$ and saline glass leachate percolating through the near-field ILAW/IDF vadose zone sediments. Kaplan et al. noted that in the "far field" vadose zone in past performance assessment calculations, some sorption was allowed for selenate. Even if the caustic glass leachate completely dominates the entire vadose zone beneath the IDF, and there is no sorption of selenate under these geochemical conditions, Kaplan et al. (2003) proposed that the dilution and $\mathrm{pH}$ neutralization of the glass leachate-modified pore water that would occur in the upper unconfined aquifer would result in some selenate adsorption onto these aquifer sediments.

Cantrell et al. (2003) compiled in a single source the $\mathrm{K}_{\mathrm{d}}$ values measured with Hanford sediment for radionuclides and contaminants of concern that have potential environmental impacts in the vadose zone and groundwater at the Hanford Site. Cantrell et al. concluded that $\mathrm{I}^{-}$is expected to be the dominant species of dissolved iodine in Hanford groundwater based on the study of Kaplan and Serne (2000). Table 11 in Cantrell et al. (2003) lists the $\mathrm{K}_{\mathrm{d}}$ values measured for iodide ( $\mathrm{I}^{-}$) adsorption onto Hanford sediment. Based on their review, they concluded that $\mathrm{I}^{-}$adsorption is relatively low, and under typical Hanford Site groundwater conditions, $K_{d}$ values for $\mathrm{I}^{-}$range from approximately 0 to $2 \mathrm{~mL} / \mathrm{g}$, with a range of 0 to $0.2 \mathrm{~mL} / \mathrm{g}$ being most typical. Cantrell et al. (2003) indicated that the available data suggest that $\mathrm{I}^{-}$ adsorption is consistent with anionic adsorption in general, in that it appears to increase under acidic conditions. However, the available data may not be sufficient to confirm this conclusion. Cantrell et al. noted that $\mathrm{pH}$ is usually 7 or greater in most Hanford geochemical environments due to the ubiquitous occurrence of carbonates in Hanford sediments. Alkaline conditions are also expected for local vadose zone areas contaminated by discharges of highly caustic wastes from disposal trenches and leaking underground storage tanks at the Hanford Site. Some studies complied by Cantrell et al. (2003) also show that long equilibration periods ( $>100$ days) result in a nonlinear increase in $\mathrm{K}_{\mathrm{d}}$ values for I' with time. Cantrell et al. (2003) could not identify an obvious reason for this increase in $\mathrm{I}^{-}$adsorption with time. They note that others have speculated that this phenomenon may have been affected by the formation of microbial colonies as some have observed in similar long-term adsorption experiments. Because such conditions are not expected to be typical of Hanford Site groundwater, Cantrell et al. (2003) recommended that these high $\mathrm{K}_{\mathrm{d}}$ values be ignored for typical transport modeling exercises.

\subsection{Neptunium}

There are 16 known isotopes of neptunium from ${ }^{228} \mathrm{~Np}$ to ${ }^{241} \mathrm{~Np}$ (Keller 1971). Only ${ }^{237} \mathrm{~Np}$, a neutron reactor product of ${ }^{238} \mathrm{~Np}(\mathrm{n}, 2 \mathrm{n})$ and ${ }^{235} \mathrm{~Np}(\mathrm{n}, \gamma)$, with a half-life of $2.144 \times 10^{6}$ years (Tuli 2004) is of interest to the IDF PA. The environmental chemistry and mobility of neptunium in surface water, groundwater, and geologic environments has been reviewed by others, such as Silva and Nitsche (1995), Tanaka et al. (1992), Lieser and Mühlenweg (1988), Coughtrey et al. (1984), Thompson (1982), Onishi et al. (1981), and Ames and Rai (1978). 


\subsubsection{Oxidation States and Aqueous Speciation}

Neptunium may exist in the $+3,+4,+5,+6$, and +7 valence states, but only the $+4,+5$, and possibly +6 states are relevant to natural environments. Neptunium(VI) is stable only in highly oxidizing solutions and is therefore not important under most environmental conditions. Neptunium(V) exists in oxidizing environmental systems and is considered relatively mobile because $\mathrm{Np}(\mathrm{V})$ aqueous species do not readily adsorb to sediment, and $\mathrm{Np}(\mathrm{V})$ solids are quite soluble. Neptunium(IV) occurs under reducing conditions and is less mobile than $\mathrm{Np}(\mathrm{V})$. Like $\mathrm{U}(\mathrm{IV})$ and $\mathrm{Pu}(\mathrm{IV}), \mathrm{Np}(\mathrm{IV})$ may form sparingly soluble oxide and hydroxide solids that limit the mobility of $\mathrm{Np}(\mathrm{IV})$ under reducing conditions.

The reduction of redox-sensitive elements such as neptunium by abiotic and biotic processes has been the subject of considerable interest because these reactions have a significant effect on the environmental mobility of redox-sensitive elements. For example, redox-sensitive elements can be immobilized by surface-mediated, heterogeneous reduction/sorption reactions on Fe(II)-containing oxide and silicate minerals that exist as coatings on sediment particles and/or primary constituents of sediments (see review in White [1990]). The heterogeneous electrochemical reactions occur by electron transfer reactions in which the $\mathrm{Fe}(\mathrm{II})$ is oxidized to $\mathrm{Fe}(\mathrm{III})$, and the redox-sensitive contaminant is reduced to a lower valence state, such as reduction of $\mathrm{Np}(\mathrm{V})$ to $\mathrm{Np}(\mathrm{IV})$. Surface-mediated, heterogeneous reduction/sorption of $\mathrm{Np}(\mathrm{V})$ has been studied by Hakanen and Lindberg (1991), Susak et al. (1983), Meyer et al. (1984), and Bondietti and Francis (1979).

The reduction of $\mathrm{Np}(\mathrm{V})$ to $\mathrm{Np}(\mathrm{IV})$ by biotic processes has also been demonstrated. Lloyd et al. (2000a) conducted a biochemical study of the reduction of $\mathrm{Np}(\mathrm{V})$. Their experiments demonstrated that Shewanella putrefaciens reduced $\mathrm{Np}(\mathrm{V})$ to a lower valence state, possibly $\mathrm{Np}(\mathrm{IV})$, but this reduction process was not sufficient to remove neptunium from solution. Lloyd et al. (2000a) were able to remove ${ }^{237} \mathrm{~Np}$ and its daughter product ${ }^{233} \mathrm{~Pa}$ from solution by bioprecipitation using a combination of the two organisms S. putrefaciens and Citrobacter sp. The bioprecipitation resulted from bioreduction to Np(IV) by $S$. putrefaciens in concert with phosphate liberation by the Citrobacter sp from the glycerol 2-phosphate solution.

The thermodynamic data for neptunium aqueous species and solids are limited and not well known relative to other radionuclides. Lemire et al. (2001) have published an extensive, detailed critical review of the chemical thermodynamics of neptunium. As noted at the beginning of Section 3.0, the thermodynamic values compiled in Lemire et al. (2001) are not in the thermodynamic database used to calculate the Eh-pH diagrams discussed in this report. Figure 3.4 is an Eh-pH diagram showing the dominant aqueous species for dissolved neptunium calculated at $25^{\circ} \mathrm{C}$ and concentrations of $1 \times 10^{-8} \mathrm{~mol} / \mathrm{L}$ total dissolved neptunium, $1 \times 10^{-3} \mathrm{~mol} / \mathrm{L}$ total dissolved carbonate, and $5 \times 10^{-6} \mathrm{~mol} / \mathrm{L}$ total dissolved fluoride. Under oxidizing conditions, the neptunyl ion, $\mathrm{NpO}_{2}{ }^{+}$, calculates to be the dominant $\mathrm{Np}(\mathrm{V})$ aqueous species at $\mathrm{pH}$ values less than 8.5. At higher $\mathrm{pH}$ values, anionic $\mathrm{Np}(\mathrm{V})$ carbonate complexes, such as $\mathrm{NpO}_{2} \mathrm{CO}_{3}{ }^{-}$and $\mathrm{NpO}_{2}\left(\mathrm{CO}_{3}\right)_{3}{ }^{5-}$, are predicted to be the aqueous complexes under oxidizing conditions. Under reducing conditions, the hydroxyl complex $\mathrm{Np}(\mathrm{OH})_{4}{ }^{0}(\mathrm{aq})$ is the dominant $\mathrm{Np}(\mathrm{IV})$ aqueous complex at $\mathrm{pH}$ values greater than 4 (Figure 3.4). Based the available thermodynamic data, the species $\mathrm{NpF}_{2}{ }^{2+}$ may be the important $\mathrm{Np}(\mathrm{IV})$ aqueous complex at very acidic $\mathrm{pH}$ values under moderately oxidizing to reducing conditions. 


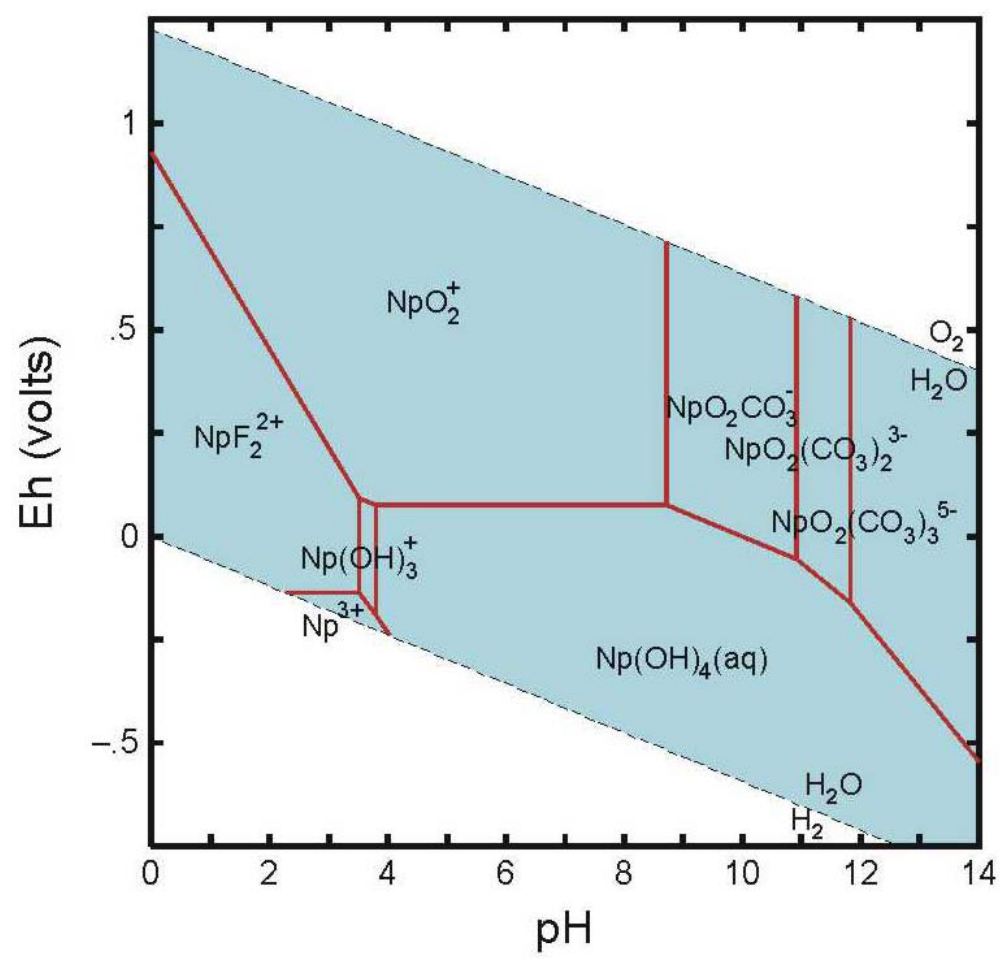

Figure 3.4. Eh-pH Diagram Showing Dominant Aqueous Species of Neptunium. (Diagram was calculated at a total concentration of $1 \times 10^{-8} \mathrm{~mol} / \mathrm{L}$ dissolved neptunium at $25^{\circ} \mathrm{C}$.)

\subsubsection{Precipitation and Coprecipitation}

The solubility of $\mathrm{Np}(\mathrm{V})$ has been studied extensively for estimating the maximum solubility concentrations of dissolved neptunium that might be released under oxidizing conditions from a geologic repository for high-level radioactive waste with subsequent migration in groundwater systems (e.g., Novak and Roberts 1995, Neck et al. 1994, Lemire 1984). If the concentrations of dissolved Np(V) are sufficiently high, the solubility of $\mathrm{Np}(\mathrm{V})$ may be controlled by hydroxide or carbonate solids. In carbonate-free aqueous solutions with $\mathrm{OH}^{-}$as the only complexing ligand, the maximum concentration of dissolved $\mathrm{Np}(\mathrm{V})$ is likely determined by the solubility product of solids, such as $\mathrm{Np}_{2} \mathrm{O}_{5} \cdot \mathrm{xH}_{2} \mathrm{O}$ (Efurd et al. 1998) or solid $\mathrm{NpO}_{2} \mathrm{OH}$ (Al Mahamid et al. 1998; Roberts et al. 1996). In carbonate-rich solutions, a variety of solids, such as hydrated $\mathrm{NaNpO}_{2} \mathrm{CO}_{3}$ (Neck et al. 1994; Lemire et al. 1993), $\mathrm{Na}_{3} \mathrm{NpO}_{2}\left(\mathrm{CO}_{3}\right)_{2}$ (Al Mahamid et al. 1998; Neck et al. 1994; Lemire et al. 1993), and $\mathrm{KNpO}_{2} \mathrm{CO}_{3}$ (Al Mahamid et al. 1998; Lemire et al. 1993), have been studied as possible solubility controls for the maximum concentrations of dissolved $\mathrm{Np}(\mathrm{V})$ under oxidizing conditions.

Under reducing conditions, $\mathrm{Np}(\mathrm{IV})$ is not considered very mobile because it forms sparingly soluble oxide and hydroxide solids. Solids such as Np(IV) hydrous oxide (Nakayama et al. 1996; Rai and Ryan 1985), amorphous $\mathrm{NpO}_{2} \times \mathrm{xH} 2 \mathrm{O}$ (Rai et al. 1987b), and amorphous $\mathrm{NpO}_{2}$ (Rai et al. 1999) have been studied as possible solubility controls for $\mathrm{Np}$ (IV). In the study by Itagaki et al. (1991), the precipitation of amorphous $\mathrm{NpO}_{2} \cdot \mathrm{xH}_{2} \mathrm{O}$ and its colloids were found to be important to the mobility of neptunium in environmental systems. Figure 3.5 shows that solid $\mathrm{NpO}_{2}$ is oversaturated over a large range of Eh-pH conditions for a system containing $1 \times 10^{-8} \mathrm{~mol} / \mathrm{L}$ total dissolved neptunium, $1 \times 10^{-3} \mathrm{~mol} / \mathrm{L}$ total dissolved 
carbonate, and $5 \times 10^{-6} \mathrm{~mol} / \mathrm{L}$ total dissolved fluoride. In the Eh-pH region defined by the tan-colored area in Figure 3.5, $\mathrm{NpO}_{2}$ calculates to be oversaturated based on the available thermodynamic data and may precipitate at these Eh-pH conditions to limit the maximum concentration of dissolved technetium in sediment.

\subsubsection{Sorption}

An extensive review of neptunium adsorption studies on sediments, soils, pure minerals, oxide phases, and crushed rock materials is presented in EPA (2004). Neptunium(V) species adsorb to some extent to iron oxide and clay minerals, but not to a major degree on most common minerals. Therefore, dissolved $\mathrm{Np}(\mathrm{V})$ is considered to be relatively mobile in soil systems. The singly charged neptunyl ion, $\mathrm{NpO}_{2}{ }^{+}$, is likely the dominant species of neptunium in the oxidizing environment of the Hanford Site vadose zone (Ames and Rai 1978). $\mathrm{NpO}_{2}{ }^{+}$does not compete favorably with $\mathrm{Ca}^{2+}$ and other common divalent ions for adsorption sites on sediments. Consequently, $\mathrm{K}_{\mathrm{d}}$ values for neptunium are usually relatively low (Routson et at. 1976; Sheppard et al. 1976).

The results of experimental studies indicate that the adsorption of $\mathrm{Np}(\mathrm{V})$ has a strong dependence on pH, especially for iron oxides (Kohler et al. 1999; Girvin et al. 1991; Allard 1984). Typically, the sorption of $\mathrm{Np}(\mathrm{V})$ on minerals is negligible at $\mathrm{pH}$ values less than 5 , and increases rapidly at $\mathrm{pH}$ values between 5 and 7. This pH-dependency is expected for ions that are present in solution primarily as cations, such as $\mathrm{NpO}_{2}^{+}$(EPA 1999a). In carbonate-containing solutions, the adsorption of $\mathrm{Np}(\mathrm{V})$ on iron

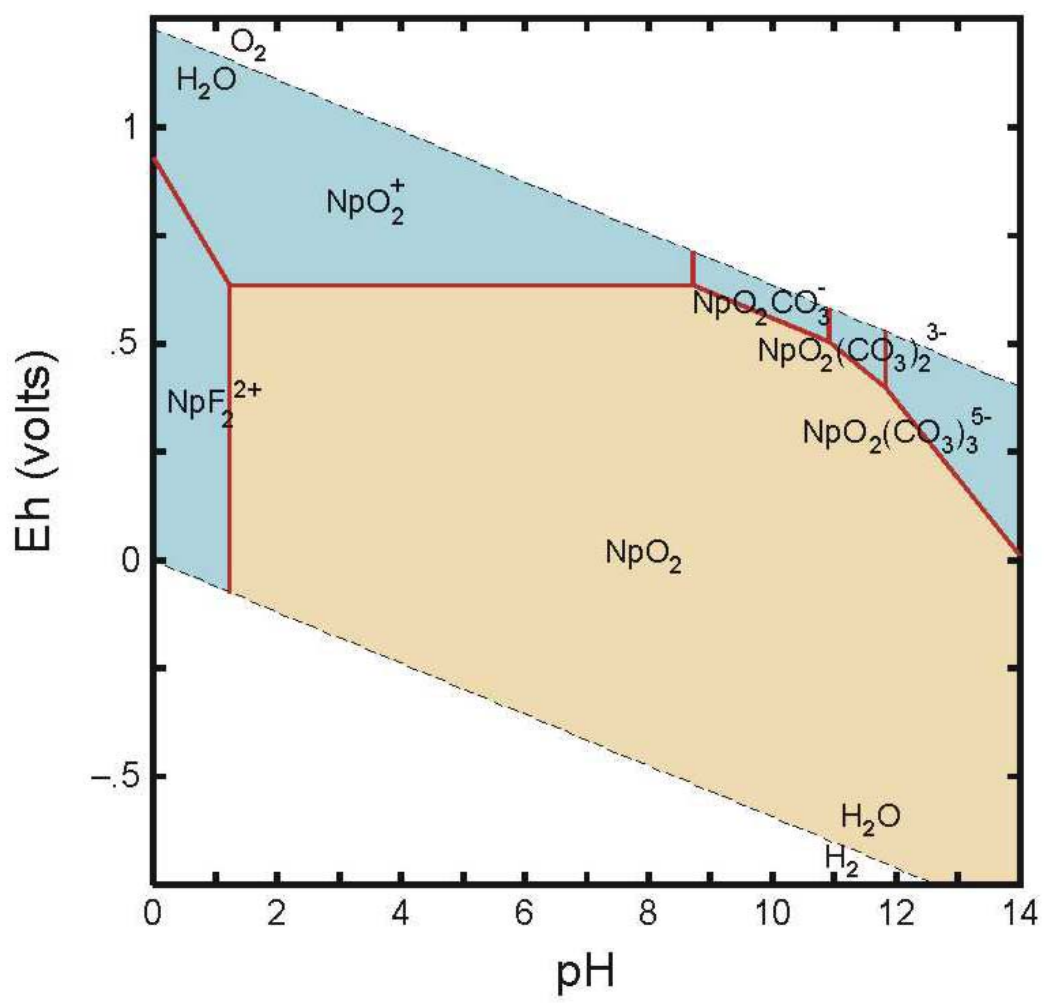

Figure 3.5. Stability Diagram Showing Eh-pH Region (tan colored) that Calculates as Oversaturated with Respect to the Solubility of Neptunium Solids. (Diagram was calculated at a total concentration of $1 \times 10^{-8} \mathrm{~mol} / \mathrm{L}$ dissolved neptunium at $25^{\circ} \mathrm{C}$.) 
oxides has been observed to decrease at $\mathrm{pH}$ values greater than 7 to 9 in response to the formation of aqueous $\mathrm{Np}$ (VI) carbonate complexes (Kohler et al. 1999). This latter behavior is analogous to that observed for the adsorption of U(VI) in carbonate-solutions at alkaline $\mathrm{pH}$ values (see Section 3.7.3).

Benson (1961) examined Np sorption to 25 common sulfide, silicate, and carbonate minerals using trace amounts of neptunium in Columbia River water at $80^{\circ} \mathrm{C}$. Neptunium was adsorbed poorly or not at all by the minerals tested. Robertson (1974) determined the speciation of neptunium in the cooling water effluent from N Reactor. Through the use of ultrafiltration and cation- and anion-exchange resins, the following distribution was observed: $25 \%$ particulate, $70 \%$ cationic, $<3 \%$ anionic, and $<1 \%$ nonionic. The fact that neptunium may become associated with a particulate phase may have implications regarding the potential role of subsurface mobile colloids in enhancing contaminant transport.

A few studies have been conducted to evaluate the propensity of neptunium to adsorb to Hanford sediments (Routson et al. 1976; Serne et al. 1993). Their results suggest low-to-moderate adsorption and are included in this data package.

Cantrell et al. (2003) compiled in a single source the $K_{d}$ values measured with Hanford sediment for radionuclides and contaminants of environmental concern to the vadose zone and groundwater at the Hanford Site. Table 13 in Cantrell et al. (2003) lists the compiled $K_{d}$ values determined for $N p(V)$ using Hanford sediment. The compiled $\mathrm{K}_{\mathrm{d}}$ values generally range from 2 to $30 \mathrm{~mL} / \mathrm{g}$, suggesting to them that $\mathrm{Np}(\mathrm{V})$ adsorption is generally moderate under these geochemical conditions. Cantrell et al. noted that lower $\mathrm{K}_{\mathrm{d}}$ values could result at contact times of one day or less and high concentrations of dissolved calcium or ethylenediaminetetraacetic acid, whereas higher $\mathrm{K}_{\mathrm{d}}$ values could result at higher solution $\mathrm{pH}$ values. They concluded that moderate migration of $\mathrm{Np}(\mathrm{V})$ could occur in the vadose zone and groundwater under natural Hanford conditions.

\subsection{Nitrate}

The behavior of nitrogen species, such as nitrate, in aqueous, soil, and geochemical systems has been discussed by Lindsay (1979), Lindsay et al. (1981), Stumm and Morgan (1981), Rai et al. (1987c), Hem (1986), and others. A large number of studies have been completed related to the chemical and biological processes that transfer nitrogen between the atmosphere, lithosphere, hydrosphere, and biosphere. Many of these nitrogen transformations in the lithosphere are controlled in large part by microorganisms. The significance and rates of these reactions are in general difficult to quantify because of the many variables that influence the rates of reactions. Nitrate is highly mobile and does not sorb or precipitate in sediment systems.

\subsubsection{Oxidation States and Aqueous Speciation}

Nitrogen can exist in several oxidation states from +6 to -3 in natural environments. In natural waters, nitrogen exists primarily in the +5 (nitrate, $\mathrm{NO}_{3}{ }^{-}$), +3 (nitrite, $\left.\mathrm{NO}_{2}{ }^{-}\right), 0\left[\mathrm{~N}_{2}\right.$ (gas)], and -3 (ammonium, $\mathrm{NH}_{4}{ }^{+}$) oxidation states. Nitrogen can occur in other forms, such as cyanide $\left(\mathrm{CN}^{-}\right)$, in aqueous systems affected by industrial waste disposal. The rate at which equilibrium is reached among the different redox states of nitrogen is very slow in abiotic systems because of the high activation energies associated with nitrogen redox reactions (Lindsay et al. 1981). 
Figure 3.6 is an Eh-pH diagram that shows the dominant aqueous species of nitrogen predicted to be present at $25^{\circ} \mathrm{C}$ and a total concentration of $1 \times 10^{-8} \mathrm{~mol} / \mathrm{L}$ dissolved nitrogen. The stability diagram was calculated assuming that $\mathrm{N}_{2}$ (gas) is unreactive and the aqueous system represented in Figure 3.6 is not in equilibrium with $\mathrm{N}_{2}$ (gas). Figure 3.6 shows that $\mathrm{NO}_{3}{ }^{-}$(nitrate) is the dominant nitrogen species over the entire $\mathrm{pH}$ range for oxic systems. Under mildly reducing conditions and lower redox conditions, nitrogen as the cationic $\mathrm{NH}_{4}{ }^{+}$and neutral $\mathrm{NH}_{3}{ }^{0}$ (aq) species are the dominant aqueous species at $\mathrm{pH}$ values less and greater than approximately 9.2, respectively. Under mildly reducing conditions, there are also two narrow Eh-pH regions where $\mathrm{N}(\mathrm{III})$ as $\mathrm{HNO}_{2}{ }^{0}$ (aq) (very acidic conditions) and $\mathrm{NO}_{2}^{-}$(near-neutral to very basic $\mathrm{pH}$ conditions) are predicted to be stable.

Nitrate under reducing conditions such as those that may occur from the presence of organic carbon cocontaminants can be reduced by certain strains of bacteria to form $\mathrm{N}_{2}$ (gas). This process is referred to as denitrification, and it acts only on nitrate ions. Besides the need for nitrate, reducing conditions, and energy source for the bacteria, temperature and $\mathrm{pH}$ also affect the rate of denitrification. Rates of denitrification approach zero at $2^{\circ} \mathrm{C}$ and $\mathrm{pH}$ values less than 5 (de Haan and Zwerman 1978).

Relative to the vadose zone under the IDF, nitrogen will be present as the highly mobile $\mathrm{NO}_{3}{ }^{-}$(nitrate) species based on thermodynamic considerations and characterization data for Hanford vadose zone sediments. For example, characterization of vadose zone sediments taken under Hanford tanks that have leaked liquid wastes containing dissolved nitrate and nitrite solutions indicate that the nitrogen is present in these impacted sediments as nitrate (for example, see Serne et al. 2002a, through d, 2004a, b).

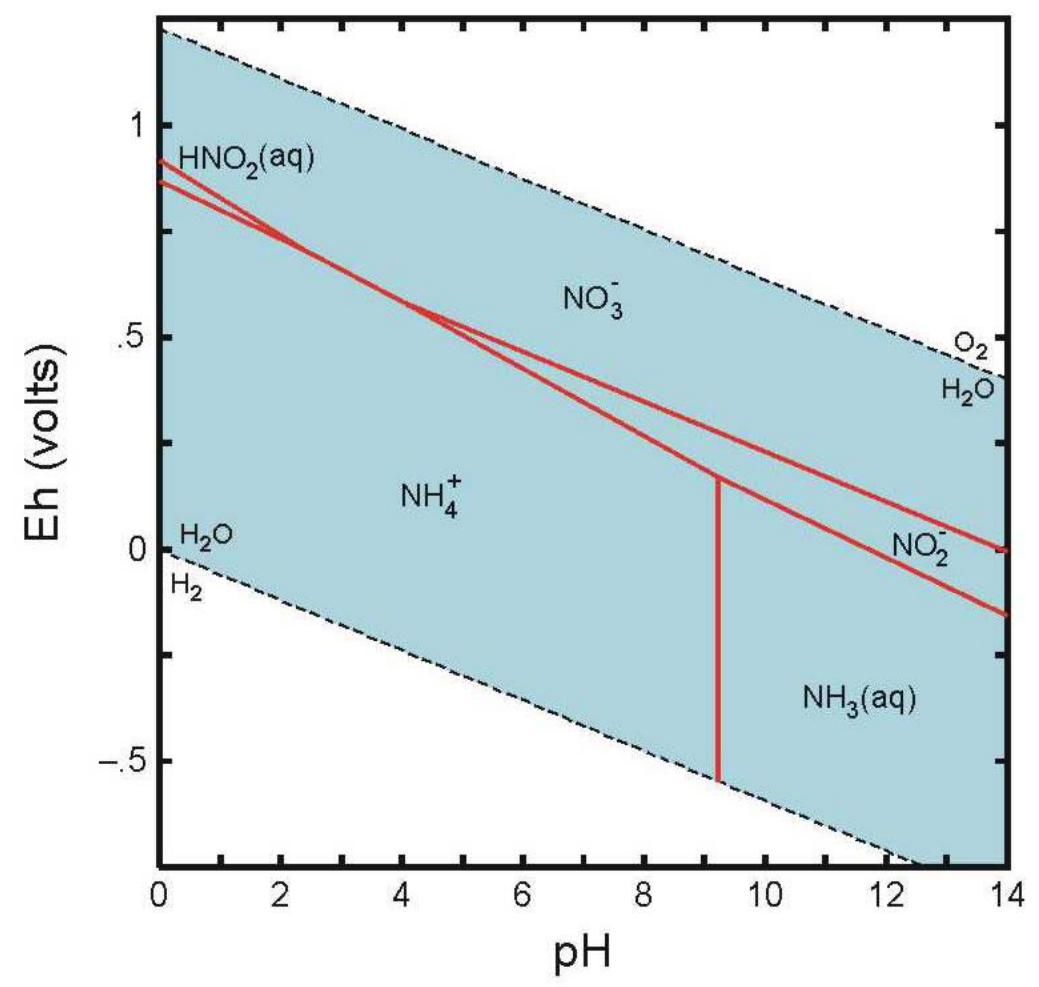

Figure 3.6. $\quad$ Eh-pH Diagram Showing Dominant Aqueous Species of Nitrogen. (Diagram was calculated at a total concentration of $1 \times 10^{-8} \mathrm{~mol} / \mathrm{L}$ dissolved nitrogen at $25^{\circ} \mathrm{C}$.) 


\subsubsection{Precipitation and Coprecipitation}

Nitrate-containing minerals such as nitratine (soda niter, $\left.\mathrm{NaNO}_{3}\right)$ and niter $\left(\mathrm{KNO}_{3}\right)$ do occur in some natural systems. These minerals are highly soluble and restricted in occurrence to highly concentrated nitrate systems, such as evaporite deposits. Although nitratine has been identified in waste sludges in Hanford tank wastes, such phases are not expected to exist, especially from leachates from the IDF, in the vadose zone or unconfined aquifer.

Bickmore et al. (2001) recently reported the formation of a nitrate form of cancrinite. $\left\{(\mathrm{Na}, \mathrm{Ca}, \mathrm{K})_{6-9}(\mathrm{Si}, \mathrm{Al})_{12} \mathrm{O}_{24}\left[\left(\mathrm{CO}_{3}\right),\left(\mathrm{SO}_{4}\right), \mathrm{Cl}_{2},\left(\mathrm{NO}_{3}\right)_{2},(\mathrm{OH})_{2}\right]_{2-4} \cdot \mathrm{n}\right\}$. in studies of mineral precipitation on quartz sand reacted with simulated Hanford tank solutions. Bickmore et al. (2001) conducted a set of batch experiments with low solid-to-solution ratios in which high $\mathrm{pH}$, high $\mathrm{NaNO}_{3}$ solutions with dissolved aluminum were reacted with quartz sand at $89^{\circ} \mathrm{C}$. Because cancrinite exhibits cation-exchange properties, investigators have speculated on the potential effect that precipitated cancrinite might have on sequestration (i.e., sorption) of contaminants of concern. Research related to solubility, kinetics of precipitation, and sorption properties of cancrinite relative to the interaction of simulated Hanford tank wastes and vadose zone sediments continues, and it is too early to judge the extent to which cancrinite precipitation might affect the mobility of contaminants in such environments. Given the thermal regime associated with Hanford storage tanks and composition (and rate of release) of the waste solutions that have leaked into the vadose zone, these conditions are far more extreme than those expected for leachates from IDF waste, and precipitation of a nitrate-form of cancrinite is not likely to occur or affect contaminant migration in the vadose zone under the IDF.

\subsubsection{Sorption}

Nitrate is one of the most widespread contaminants associated with past Hanford operations. The most prominent portions of this contamination originated at waste sites in the 200 Areas and spread toward the southeast (Hartman et al. 2004). Elevated nitrate concentrations in some areas of the Hanford Site are likely related to offsite activities. For example, elevated nitrate levels measured in groundwater from the 200-ZP-1 Operable Unit in the western part of the Hanford Site are believed to be due to offsite agriculture, the application of fertilizers, and irrigation (Hartman et al. 2004). Nitrate contamination in the 1100-EM-1 groundwater interest likely results from industrial and agricultural uses of the Hanford Site (Hartman et al. 2004).

Nitrate does not readily adsorb on minerals under near-neutral and slightly alkaline $\mathrm{pH}$ conditions common in sediment systems and is typically not included in most databases of $\mathrm{K}_{\mathrm{d}}$ values such as Thibault et al. (1990). Nitrate $\left(\mathrm{NO}_{3}{ }^{-}\right)$and nitrite $\left(\mathrm{NO}_{2}{ }^{-}\right)$are typically assigned $\mathrm{K}_{\mathrm{d}}$ values of $0 \mathrm{~mL} / \mathrm{g}$. As anions, their adsorption is expected to be high under acidic conditions, decrease with increasing $\mathrm{pH}$ values, and be essentially nil at slightly to highly basic $\mathrm{pH}$ conditions. Ammonium $\left(\mathrm{NH}_{4}{ }^{+}\right)$cations are highly adsorbed to mineral surfaces, but no attempt was made in this review to identify $\mathrm{K}_{\mathrm{d}}$ values for this nitrogen species because it not expected to be present in Hanford vadose zone sediments.

Cantrell et al. (2003) identified only one study in which nitrate $\left(\mathrm{NO}_{3}{ }^{-}\right)$adsorption was measured using Hanford sediment. The limited number of $\mathrm{K}_{\mathrm{d}}$ values determined for $\mathrm{NO}_{3}{ }^{-}$from this study are listed in Table 12 in Cantrell et al. (2003). Based on these measurements, they concluded that within experimental error, that $\mathrm{NO}_{3}{ }^{-}$adsorption under Hanford relevant conditions is essentially zero (i.e., $\mathrm{K}_{\mathrm{d}}=0$ ). 


\subsection{Selenium}

Selenium-79 is a long-lived fission product whose half-life is $2.95 \times 10^{5}$ years (Tuli 2004). The stable, nonradioactive form of selenium is ubiquitous, especially in sediments in the western United States. After nonradioactive selenium was found to be the cause of reduced fecundity of migrating birds in the mid-1980s (Ohlendorf et al. 1988), much research was directed at understanding the environmental fate of selenium.

The geochemistry and environmental behavior of selenium in sediment, soil, groundwater, and geological systems is reviewed by the National Academy of Sciences (NAS 1976), Rai et al. (1984), Elrashidi et al. (1989), Mayland et al. (1989), McNeal and Balistrieri (1989), and others. The aqueous speciation and possible solubility controls for selenium in soil systems are discussed by Rai et al. (1984) and Elrashidi et al. (1989).

\subsubsection{Oxidation States and Aqueous Speciation}

Selenium can be found in the $-2,0,+4$, and +6 oxidation states (Baes and Mesmer 1976). The Eh-pH diagram in Figure 3.7 shows the dominant aqueous species for dissolved selenium. The diagram was calculated at $25^{\circ} \mathrm{C}$ using a concentration of $1 \times 10^{-8} \mathrm{~mol} / \mathrm{L}$ total dissolved selenium and is consistent with the Eh-pH diagram given for selenium inorganic aqueous species in Rai et al. (1984). As indicated in Figure 3.7, dissolved selenium will be present in the +6 oxidation state (selenate) under oxidizing

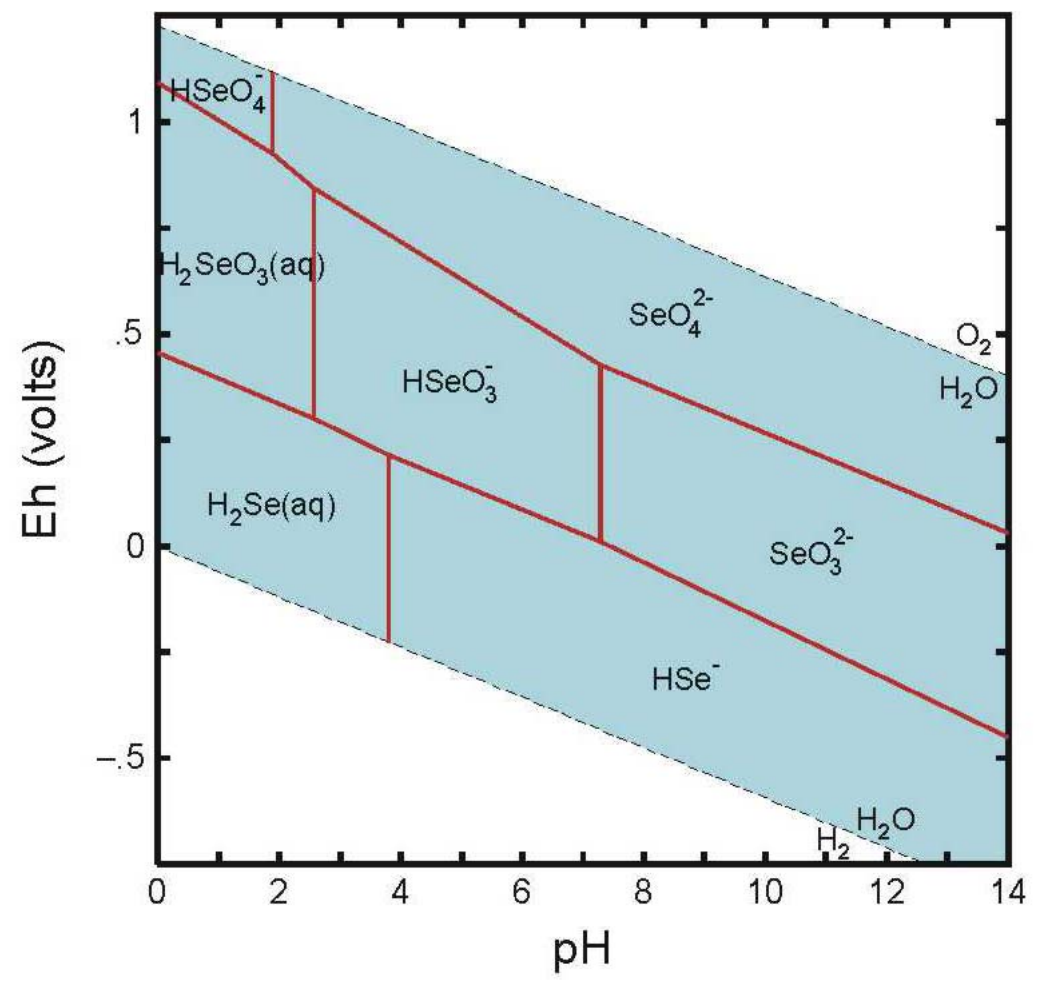

Figure 3.7. Eh-pH Diagram Showing Dominant Aqueous Species of Selenium. (Diagram was calculated at a total concentration of $1 \times 10^{-8} \mathrm{~mol} / \mathrm{L}$ dissolved selenium at $25^{\circ} \mathrm{C}$.) 
conditions as the dominant species $\mathrm{HSeO}_{4}{ }^{-}$and $\mathrm{SeO}_{4}{ }^{2-}$ at $\mathrm{pH}$ values less than and greater than 2, respectively. Under moderately oxidizing to reducing conditions, the $\mathrm{Se}(\mathrm{IV})$ (selenite) species $\mathrm{H}_{2} \mathrm{SeO}_{3}{ }^{0}(\mathrm{aq})$, $\mathrm{HSeO}_{3}{ }^{-}$, and $\mathrm{SeO}_{3}{ }^{2-}$ calculate to be dominant at $\mathrm{pH}$ values less than approximately 2.5 , from 2.5 to 7 , and greater than 7, respectively. Selenate and selenite may form ion-pair species with $\mathrm{Ca}^{2+}$. The $\mathrm{Se}(-\mathrm{II})$ species $\mathrm{H}_{2} \mathrm{Se}^{0}$ (aq) and $\mathrm{HSe}^{-}$are the dominant aqueous species of selenium, at $\mathrm{pH}$ values less than and greater than about 4, respectively, under highly reducing conditions. The Eh-pH diagram (Figure 3.7) also indicates that dissolved selenium in the $-2,+4$, and +6 oxidation states will be present as anionic species at $\mathrm{pH}$ values greater than 4 under all redox conditions within the stability range of water.

The formation of methylated forms of selenium, such as dimethyl selenide $\left(\mathrm{CH}_{3} \mathrm{SeCH}_{3}\right)$ and dimethyl diselenide $\left(\mathrm{CH}_{3} \mathrm{SeSeCH}_{3}\right)$, has been detected and studied in laboratory experiments and environmental systems (e.g., Chasteen 1998; Guo et al. 1999; Zhang et al. 1999; Zhang and Frankenberger 2000). Chasteen (1998) gives a detailed review of the volatile chemical species of selenium. Due to the relatively high vapor pressure of these compounds, the formation of methylated forms of selenium can be significant contributors to the mobility of selenium in environmental systems.

\subsubsection{Precipitation and Coprecipitation}

In some sediment systems under moderately and highly reducing conditions, the concentration of dissolved selenium may be controlled by precipitation of selenium solids such as elemental selenium $\left(\mathrm{Se}^{\mathrm{o}}\right)$. Figure 3.8 shows the Eh-pH region (tan area) that calculates as oversaturated with respect to solid $\mathrm{Se}^{\mathrm{o}}$ for an aqueous solution containing a total concentration of dissolved selenium of $10^{-8} \mathrm{~mol} / \mathrm{L}$.

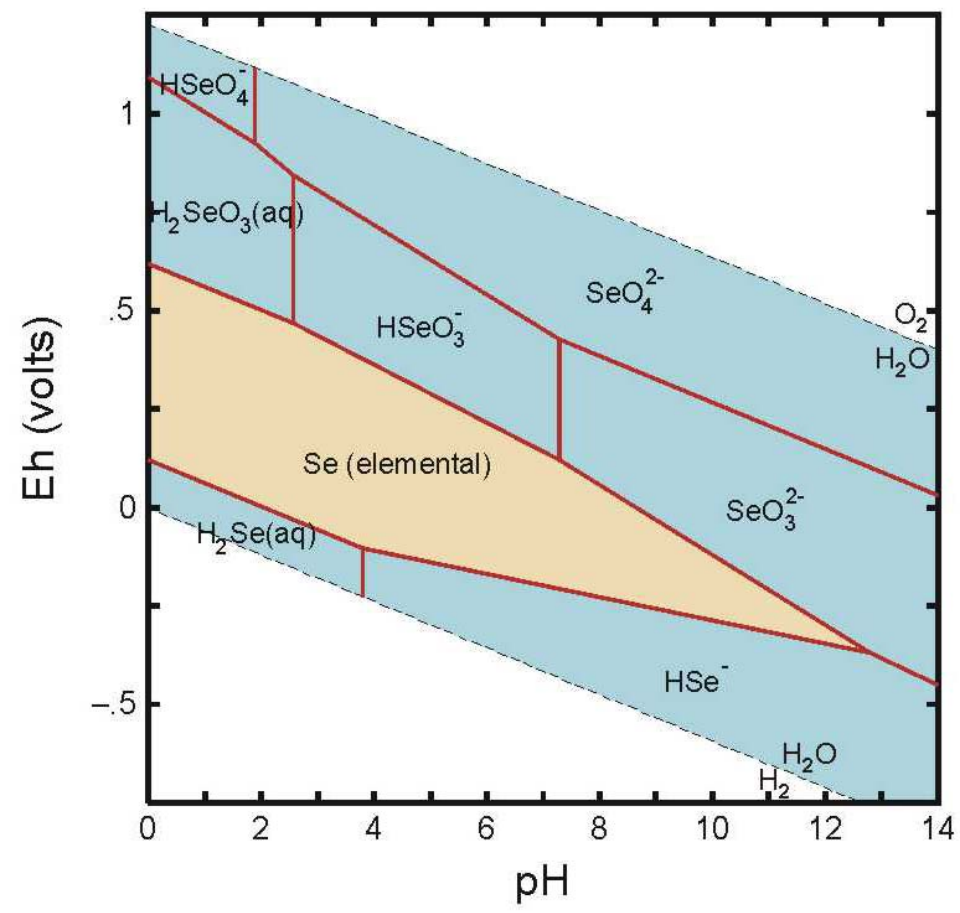

Figure 3.8. $\quad$ Stability Showing Region (tan colored) that Calculates to be Oversaturated with Respect to the Solubility of Elemental Selenium. (Diagram was calculated at a total concentration of $1 \times 10^{-8} \mathrm{~mol} / \mathrm{L}$ dissolved selenium at $25^{\circ} \mathrm{C}$.) 
Figure 3.8 is essentially identical to the Eh-pH solubility diagram in McNeal and Balistrieri (1989). These calculations indicate that elemental selenium is relatively insoluble in sediments over a wide range of $\mathrm{pH}$ and moderately reducing conditions and would limit the mobility of selenium in such environmental systems. In highly reducing and organic-rich systems containing dissolved sulfide or bisulfide, selenium-sulfide solids and metal selenides such as ferroselite $\left(\mathrm{FeSe}_{2}\right)$ are insoluble and would limit the concentration of dissolved selenium and its mobility in soil systems. Though several solid phases such as $\mathrm{FeSe}_{2}$ are predicted to be stable under relatively reducing conditions, and some studies indicate that precipitation may be occurring, no definitive information on selenium solubility-controlling solids is available. The solubility products, $\mathrm{K}_{\text {sp }}$, for $\mathrm{FeSe}_{2}$ or the other selenium compounds, moreover, are not well defined.

Geering et al. (1968) has proposed that formation of the solid $\mathrm{Fe}(\mathrm{OH})_{4} \mathrm{SeO}_{3}$ may help explain the insolubility of selenium in sediments as well as the strong association of selenium with iron in precipitates. Benjamin and Bloom (1981) observed that metal ion adsorption onto amorphous iron oxyhydroxides was enhanced in the presence of an iron-selenium solid phase adsorbed on the oxyhydroxide surface. They observed that selenite was irreversibly adsorbed on crystalline iron oxide surfaces (goethite, hematite).

Selenium can be reduced to its lower oxidation states by abiotic and biotic processes. Studies by Losi and Frankenberger (1998), Nelson et al. (1996), Poole and Porter (1999), and others show that dissolved selenium can be reduced by bacteria. These reactions can result in the bioreduction of selenium to insoluble forms, such as solid elemental selenium $\left(\mathrm{Se}^{\mathrm{o}}\right)$ or $\mathrm{S}_{1-\mathrm{x}} \mathrm{Se}_{\mathrm{x}}$, which will limit the mobility and bioavailability of selenium in sediment systems.

As discussed previously, results by Mattigod et al. $(2002,2003)^{(a)}$ from waste glass weathering studies conducted in support of the ILAW/IDF PA suggest that under oxic conditions, secondary products that form from the weathering of ILAW waste glasses may incorporate small masses of anionic contaminants, such as selenate, that may be resistant to remobilization. The reader is referred to Section 3.2.2 for a description of the studies by Mattigod et al. $(2002,2003) .{ }^{\text {(a) }}$ With respect to the uptake of selenate, Mattigod et al. $(2003,2004)$ determined in experiments completed with radionuclide-spiked groundwater that $\sim 6$ to $15 \%$ of ${ }^{75} \mathrm{Se}$ was sorbed in the secondary crystalline phases and hydrated gel layer that formed from the leaching of waste glasses. Mattigod et al. (2003) ${ }^{(a)}$ found a similar amount of ${ }^{75} \mathrm{Se}$ sorption ( $\sim 8$ to $14 \%$ ) when $1 \mathrm{M} \mathrm{NaOH}$ was used as the spiked leachate. In desorption experiments, Mattigod et al. determined that $\sim 60$ to $70 \%$ and 30 to $90 \%$ of the sorbed ${ }^{75} \mathrm{Se}$, respectively, in the weathered LAWBP1 and LAWA44 glasses did not easily desorb from the weathering glasses when contacted with groundwater-like solutions. Until this apparent coprecipitation (or specific adsorption) of Se(VI) in waste glass weathering products is further quantified, this process is not included in transport calculations or the geochemical data package for the 2005 IDF ILAW PA. This will build a degree of conservatism into the PA calculations that could be dealt with (removed) if quantitative data for the extent of weathering product formation per unit mass of waste glass and the mass of coprecipitated contaminants of interest in these weathering products become available at a later date.

(a) Mattigod SV, RJ Serne, BP McGrail, VL LeGore, and KE Parker. 2004 (in review). "Sequestration of radionuclides $\left({ }^{125} \mathrm{I},{ }^{54} \mathrm{Se},{ }^{99} \mathrm{Tc}\right)$ in secondary crystalline minerals resulting from chemical weathering of selected waste glasses." To be submitted to Radiochimica Acta. 


\subsubsection{Sorption}

The concentration of selenium in most soil systems under oxidizing conditions is likely controlled by adsorption processes. Because the dominant aqueous species of $\mathrm{Se}(\mathrm{IV})$ and $\mathrm{Se}$ (VI) are anionic over the $\mathrm{pH}$ range of most soils (see Figure 3.7), the adsorption of selenium to mineral surfaces would be expected to be minimal to zero in most soil systems under oxidizing and moderately reducing conditions. Laboratory studies indicate that, in spite of their anionic nature, Se(IV) (selenite) and $\mathrm{Se}(\mathrm{VI})$ (selenate) may be adsorbed significantly by some soils. The experimental evidence suggests that crypto-crystalline and amorphous forms of $\mathrm{SiO}_{2}, \mathrm{Al}_{2} \mathrm{O}_{3}$, and $\mathrm{Fe}_{2} \mathrm{O}_{3}$ control selenium adsorption (John et al. 1976; Singh et al. 1981). Studies with pure mineral phases demonstrate that hydrous oxides of iron and aluminum and amorphous aluminosilicates have a high affinity for Se(IV, VI) (Leckie et al. 1980; Hingston et al. 1968), which significantly exceeds that of layer lattice silicates (Frost and Griffin 1977; Hamby and GisselNelson 1977; Singh et al. 1981). Selenium(VI) may be adsorbed more strongly by clay minerals than selenite (Frost and Griffin 1977), while the inverse applies to iron hydrous oxides (Leckie et al. 1980; Benjamin and Bloom 1981).

The adsorption of $\mathrm{Se}(\mathrm{IV})$ and $\mathrm{Se}(\mathrm{VI})$ on goethite, amorphous iron oxyhydroxide, and gibbsite is strongly pH dependent (Hingston et al. 1968, 1972; Leckie et al. 1980). The anions are strongly sorbed under acidic conditions, but sorption decreases with increasing $\mathrm{pH}$. Limited experimental evidence suggests that, at a given $\mathrm{pH}$, selenium adsorbs to neutral and positively charged amphoteric oxide surfaces displacing water, hydroxyls, and other adsorbed ligands (e.g., sulfate, silicate) until the surface is neutral in charge (Rajan 1979).

The presence of competing anions may reduce Se(IV) and Se(VI) adsorption by using limited ligandexchange sites and reducing surface net positive charge. Phosphate reduces selenium adsorption on goethite, though some sites are specific to selenium (Hingston et al. 1971). Sulfate reduces Se(VI) adsorption on amorphous iron oxyhydroxides in a manner consistent with the competitive Langmuir equation (Leckie et al. 1980).

Um and Serne ${ }^{(a)}$ completed a series of batch and column adsorption studies of ${ }^{99} \mathrm{Tc},{ }^{129} \mathrm{I},{ }^{75} \mathrm{Se}(\mathrm{a}$ surrogate for ${ }^{79} \mathrm{Se}$ ), and ${ }^{90} \mathrm{Sr}$ on Hanford sediments collected from an ILAW borehole (C3177) at the 200 East Area. The batch sorption experiments were conducted using both uncontaminated Hanford groundwater and simulated glass leachates spiked with individual radionuclides. Um and Serne reported $\mathrm{K}_{\mathrm{d}}$ values for the adsorption of ${ }^{75} \mathrm{Se}$ (as selenate) in Hanford groundwater on C3177 sediment from the 45-, 110-, and 215-ft below ground surface of 7.14 \pm 0.18 (pH 7.7), 7.17 \pm 0.20 (pH 7.6), and $8.65 \pm 0.34 \mathrm{~mL} / \mathrm{g}(\mathrm{pH} 7.6)$, respectively. The $\mathrm{K}_{\mathrm{d}}$ values for ${ }^{75} \mathrm{Se}$ measured in simulated glass leachate for the equivalent sediment samples were $1.35 \pm 0.10(\mathrm{pH} 9.0), 2.68 \pm 0.12(\mathrm{pH} 8.9)$, and $1.08 \pm 0.09 \mathrm{~mL} / \mathrm{g}$ ( $\mathrm{pH}$ 8.9), respectively. These measurements indicate intermediate adsorption affinity for selenium on these sediments in both Hanford groundwater and simulated glass leachates. Um and Serne concluded that these adsorption data corroborate values obtained for sediments collected in the past from nearby locations and for generic aqueous solutions such as regional groundwater. They also noted that the new results provide more technical defensibility for past ILAW/IDF performance assessment predictions that did not use site-specific sediments and/or leachates.

(a) Um W and RJ Serne. 2004. "Sorption and Transport Behavior of Radionuclides in the Proposed Low-Level Radioactive Waste Disposal Facility at the Hanford Site, Washington." Submitted to Radiochimica Acta. 
As described in Section 3.2.3, Kaplan et al. (2003) studied the influence of $\mathrm{NaOH}$ solutions, a simplified surrogate for glass leachate, on the hydraulic, physical, mineralogical, and sorptive properties of Hanford sediment. This study also included a series of batch sorption tests with Warden soil that Kaplan et al. used to measure the $\mathrm{K}_{\mathrm{d}}$ values for cesium, strontium, iodide, selenate, and pertechnetate in soils treated with caustic solutions for up to 360 days. Kaplan et al. did not detect any appreciable adsorption for iodide, selenate, or pertechnetate (i.e., $\mathrm{K}_{\mathrm{d}}=0$ ) on Hanford sediment contacted with $\mathrm{NaOH}$ solutions. Some adsorption of selenate was measured in control tests using sodium perchlorate solutions at neutral $\mathrm{pH}$, but after caustic treatment and in high $\mathrm{pH}$ solutions, selenate sorption was determined to be nil. Section 3.2.3 contains a more complete summary of the results from Kaplan et al. (2003).

Table 14 in Cantrell et al. (2003) lists the compiled $\mathrm{K}_{\mathrm{d}}$ values determined for $\mathrm{Se}(\mathrm{VI})$ using Hanford sediment. Based on their review, Cantrell et al. (2002) concluded that at trace concentrations, adsorption of $\mathrm{Se}(\mathrm{VI})$ to Hanford sediment is low to moderate, with $\mathrm{K}_{\mathrm{d}}$ values typically ranging from 3 to $10 \mathrm{~mL} / \mathrm{g}$. At higher $\mathrm{Se}(\mathrm{VI})$ concentrations they found that the published selenium $\mathrm{K}_{\mathrm{d}}$ values were lower, (0 to 3 $\mathrm{mL} / \mathrm{g})$. Consistent with the anionic character of $\mathrm{Se}(\mathrm{VI})$, the data compiled by Cantrell et al. indicate that $\mathrm{Se}(\mathrm{VI})$ adsorption increases under acidic conditions and decreases under basic conditions.

\subsection{Technetium}

All isotopes of technetium are radioactive. Several technetium isotopes are obtained by the fissioning of nuclear fuels in the reactor. The technetium isotopes and their yields resulting from uranium fission include ${ }^{99} \mathrm{Tc}, 6.06 \% ;{ }^{101} \mathrm{Tc}, 5.6 \% ;{ }^{102} \mathrm{Tc}, 4.3 \% ;{ }^{103} \mathrm{Tc}, 3.0 \% ;{ }^{104} \mathrm{Tc}, 1.8 \% ;{ }^{105} \mathrm{Tc}, 0.9 \%$; and ${ }^{106} \mathrm{Tc}, 0.19 \%$. Of these, only ${ }^{99} \mathrm{Tc}$ is a potential hazard from long-term burial of ILAW and other DOE defense wastes because this isotope has a long half-life $\left(2.11 \times 10^{5}\right.$ years $)$ (Tuli 2004).

The behavior of technetium in environmental systems, especially under oxidizing conditions, has been reviewed extensively by Lieser (1993), Gu and Schulz (1991), Sparks and Long (1987), Meyer et al. (1985), Beasley and Lorz (1984), Coughtrey et al. (1983), Onishi et al. (1981), Wildung et al. (1979), Ames and Rai (1978), and others. Hughes and Rossotti (1987) reviewed in detail the solution chemistry of technetium. Studies of technetium under reducing conditions are much fewer than studies conducted under oxic conditions.

\subsubsection{Oxidation States and Aqueous Speciation}

Technetium exists in oxidation states from +7 to -1 . In natural environments, the most stable oxidation states of technetium are +7 and +4 under oxidizing and reducing conditions, respectively. The most stable and characteristic oxidation state of technetium in slightly acid, neutral, or basic aqueous solutions in equilibrium with the atmosphere is pertechnetate ion $\left(\mathrm{TcO}_{4}^{-}\right)$in which technetium is in the +7 oxidation state (Coughtrey et al. 1983; Hanke et al. 1986). Various Tc(V), Tc(IV), or Tc(III) species may be formed under reducing conditions (Pilkington 1990); the most stable of these reduced oxidation states is generally Tc(IV) (Bondietti and Francis 1979). Other reduced oxidation states are encountered chiefly in complex compounds (Mazzi 1989). Reduced technetium aqueous species are rapidly oxidized to Tc(VII) by atmospheric oxygen (Coughtrey et al. 1983). Regardless of the oxidation state emanating from the near field, technetium is likely to be in the +7 oxidation state once it reaches the far field. 
The reduction of $\mathrm{Tc}(\mathrm{VII})$ to $\mathrm{Tc}(\mathrm{IV})$ by abiotic and biotic processes has recently been the subject of extensive studies because it has a significant effect on the mobility of technetium in waste streams, vadose zones, sediments, and groundwater. These reaction processes are the basis for certain remediation technologies such as permeable barriers composed of zero-valent iron particles (i.e., as metallic iron) or sodium-dithionite reduced soils, which are being tested for immobilization of groundwater contaminants. Microbial reduction of Tc(VII) has also been suggested as a potential mechanism for removing technetium from contaminated groundwaters and waste streams (e.g., Lovley 1993, 1995). Certain dissimilatory metal reducing bacteria and sulfate reducing bacteria have been determined to be capable of coupling the oxidation of organic carbon or hydrogen to the reduction of Tc(VII) to Tc(IV) (Lloyd and Macaskie 1996; Lloyd et al. 1997, 1998, 1999, 2000a,b; Wildung et al. 2000; Fredrickson et al. 2000).

Figure 3.9 is an Eh-pH diagram showing the dominant aqueous hydrolytic species of technetium in the absence of dissolved ligands other than hydroxide. The diagram was calculated at $25^{\circ} \mathrm{C}$ using a concentration of $1 \times 10^{-8} \mathrm{~mol} / \mathrm{L}$ total dissolved technetium. Dissolved technetium is present in oxic environmental systems as the aqueous $\mathrm{Tc}(\mathrm{VII})$ oxyanion species $\mathrm{TcO}_{4}{ }^{-}$over the complete $\mathrm{pH}$ range of natural waters and is not known to form any strong aqueous complexes. The $\mathrm{TcO}_{4}{ }^{-}$anion is essentially nonadsorptive, i.e., $\mathrm{K}_{\mathrm{d}}$ values are $\approx 0 \mathrm{~mL} / \mathrm{g}$ at near-neutral and basic $\mathrm{pH}$ values (EPA 2004) and also highly soluble (Baes and Mesmer 1976; Pilkington 1990). The concentration of Tc(VII) in sediments and groundwater will therefore not be limited by adsorption or solubility processes and thus will be highly mobile in oxic environments.

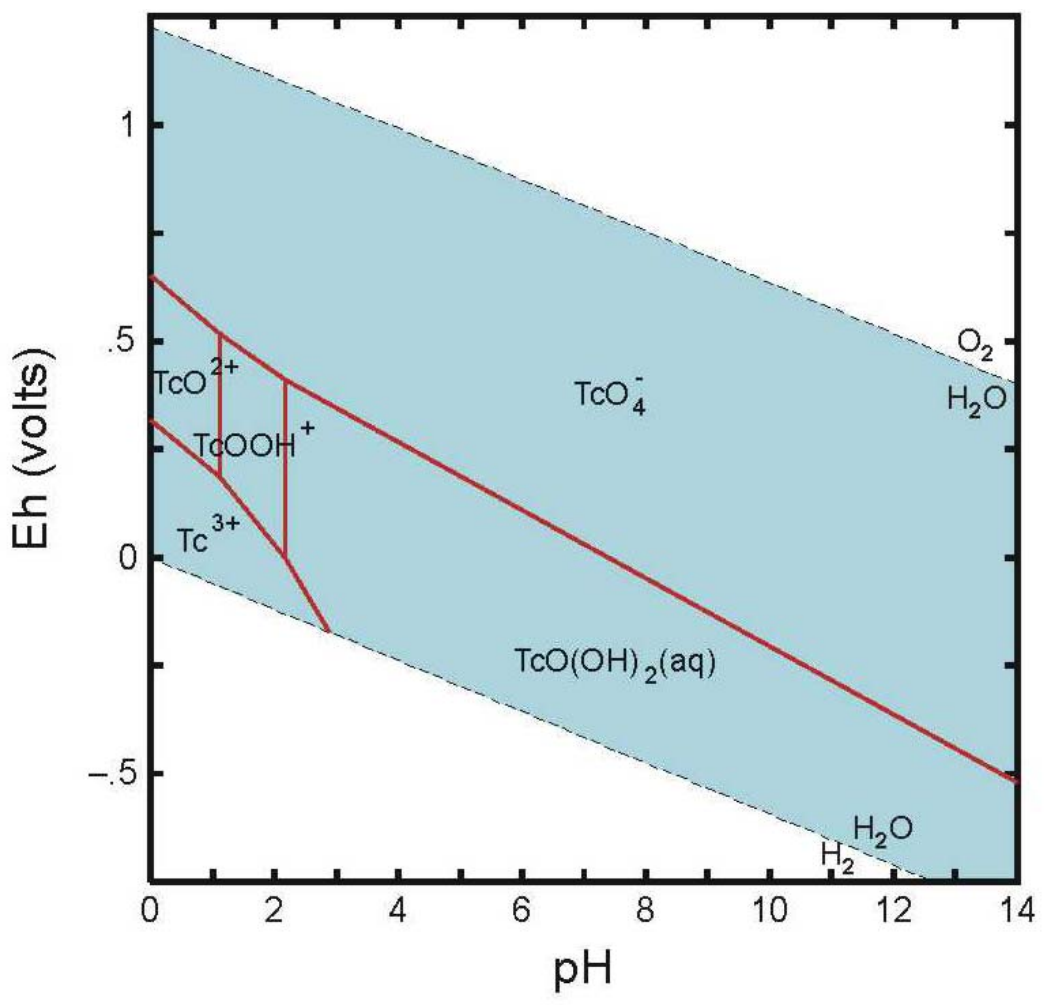

Figure 3.9. Eh-pH Diagram Showing Dominant Aqueous Species of Technetium. (Diagram was calculated at a total concentration of $1 \times 10^{-8} \mathrm{~mol} / \mathrm{L}$ dissolved technetium at $25^{\circ} \mathrm{C}$.) 
In alkaline solutions and low redox potentials, technetium aqueous speciation is dominated at $\mathrm{pH}$ values greater than 2 by the neutral Tc(IV) species $\mathrm{TcO}(\mathrm{OH})_{2}{ }^{0}(\mathrm{aq})$ in the absence of dissolved carbonate (Figure 3.9). In carbonate-containing waters, Tc(IV) carbonate complexes such as $\mathrm{TcCO}_{3}(\mathrm{OH})_{2}{ }^{0}(\mathrm{aq})$ and $\mathrm{TcCO}_{3}(\mathrm{OH})_{3}{ }^{-}$may become important aqueous complexes of technetium (Eriksen et al. 1992; Paquette and Lawrence 1985). Thermodynamic calculations suggest the possible formation of $\mathrm{Tc}^{3+}$ at $\mathrm{pH}$ values less than 2 under extremely reducing conditions. Technetium(IV) is sparingly soluble and highly sorbed and is therefore considered to be essentially immobile in reducing environments.

Rard et al. (1999) published an extensive, detailed review of the chemical thermodynamics of technetium aqueous species and solids. As previously noted, the thermodynamic database used to calculate the Eh-pH diagram herein predates the data tabulated by Rard et al. Although the thermodynamic stability of $\mathrm{TcO}_{4}{ }^{-}$is well established, thermodynamic data for other aqueous complexes and solids containing technetium in its various valence states are extremely limited. The absence of such data precludes the use of thermodynamic calculations to evaluate the environmental behavior of reduced species of dissolved technetium with respect to $\mathrm{pH}$, Eh, and the presence of important dissolved complexing ligands such as dissolved phosphate, sulfate, chloride, and others. The Tc(IV) carbonate complexes $\mathrm{TcCO}_{3}(\mathrm{OH})_{2}{ }^{0}(\mathrm{aq})$ and $\mathrm{TcCO}_{3}(\mathrm{OH})_{3}{ }^{-}$are the only non-hydrolytic aqueous complexes of technetium for which Rard et al. (1999) list Gibbs free energy of formation $\left(\Delta \mathrm{G}_{\mathrm{f}, 298}\right)$ values. The thermodynamic constants listed for $\mathrm{TcCO}_{3}(\mathrm{OH})_{2}{ }^{0}(\mathrm{aq})$ and $\mathrm{TcCO}_{3}(\mathrm{OH})_{3}{ }^{-}$are based on the solubility study of solid $\mathrm{TcO}_{2} \cdot \mathrm{xH}_{2} \mathrm{O}$ completed in presence and absence of $\mathrm{CO}_{2}$ gas by Eriksen et al. (1992). No independent measurements exist to verify the composition and thermodynamic properties of the Tc(IV) aqueous carbonate complexes.

Technetium(IV) carbonate complexes likely affect the aqueous speciation and solubility of Tc(IV) at near-neutral and/or basic $\mathrm{pH}$ conditions. The results of other studies suggest the formation of Tc(IV) aqueous carbonate complexes. For example, Paquette and Lawrence (1985) reported spectroelectrochemical evidence for the formation of aqueous carbonate complexes with both Tc(III) and Tc(IV). Wildung et al. (2000) studied the effects of electron donor and the presence of dissolved bicarbonate on enzymatic reduction of Tc(VII) by the metal-reducing bacterium Shewanella putrefaciens CN32. Based on the results of experiments conducted in bicarbonate solutions, Wildung et al. proposed the formation of a soluble, negatively charged $\mathrm{Tc}(\mathrm{IV})$ carbonate complex that exceeds $\mathrm{Tc}(\mathrm{VII})$ in electrophoretic mobility and possibly dominates the speciation of dissolved Tc(IV) over neutral and basic $\mathrm{pH}$ values. Given that anionic aqueous complexes do not readily adsorb to geologic materials under near-neutral and basic $\mathrm{pH}$ conditions, Wildung et al. (2000) suggested that the formation of anionic Tc(IV) carbonate complex(es) may represent an important mechanism for technetium migration in reducing geochemical environments. Generally, it has been assumed that technetium mobility in reducing environments is limited by the low solubility of Tc(IV) hydrous oxide (see Section 3.6.2) and adsorption of aqueous $\mathrm{Tc}(\mathrm{IV})$ hydrolytic complexes. Given that dissolved carbonate is ubiquitous in surface and subsurface environments, further research is needed to determine the composition and thermodynamic properties of $\mathrm{Tc}(\mathrm{IV})$ carbonate complexes.

Many species distribution calculations and Eh-pH diagrams presented in literature published before the critical review by Rard et al. (1999) include the aqueous neutral dimer species $\left[\mathrm{TcO}(\mathrm{OH})_{2}\right]_{2}{ }^{0}(\mathrm{aq})$. For many calculations, $\left[\mathrm{TcO}(\mathrm{OH})_{2}\right]_{2}{ }^{0}(\mathrm{aq})$ was predicted to be the dominant $\mathrm{Tc}(\mathrm{IV})$ species at neutral and basic $\mathrm{pH}$ values instead of the monomer $\mathrm{TcO}(\mathrm{OH})_{2}{ }^{0}(\mathrm{aq})$. Moreover, the calculated Eh-pH stability field for the dimer $\left[\mathrm{TcO}(\mathrm{OH})_{2}\right]_{2}{ }^{0}(\mathrm{aq})$ expanded in Eh-pH space with increasing concentrations of dissolved $\mathrm{Tc}(\mathrm{IV})$ due 
to its stoichiometric factor. Rard et al. (1999) found it difficult to evaluate the results of the study on which the dimer species and associated thermodynamic constant were based and thus did not accept those results and the species $\left[\mathrm{TcO}(\mathrm{OH})_{2}\right]_{2}{ }^{0}$ (aq) for their thermodynamic database for technetium compounds.

\subsubsection{Precipitation and Coprecipitation}

Precipitation of "pure" Tc(VII)-containing solids is not likely to be an important geochemical process affecting ${ }^{99} \mathrm{Tc}$ transport through the Hanford Site vadose zone. Technetium(VII) forms very soluble oxides and halide complexes (Baes and Mesmer 1976) and does not form solubility-controlling phases in geochemical systems. On the other hand, recent unpublished work on sludge from Hanford single-shell tanks before and after sluicing retrieval shows that technetium can be incorporated into (coprecipitate) other sparingly soluble compounds that form within the Hanford tank environments. It is not clear yet whether the technetium remains Tc(VII) or gets reduced to Tc(IV)—or whether the technetium that is actually incorporated into the solid crystal structure is just physically trapped.

If $\mathrm{Tc}(\mathrm{VII})$ is reduced to Tc(IV) in the near field, it may form a number of sparingly insoluble compounds such as $\mathrm{TcO}_{2} \cdot 2 \mathrm{H}_{2} \mathrm{O}$ or technetium sulfide solids. Numerous investigations have been conducted to determine the properties and hydration number of solid $\mathrm{TcO}_{2} \cdot \mathrm{nH}_{2} \mathrm{O}$ (see review of studies in Rard et al. 1999). Characterization data for this solid are limited, and a range of compositions, such as $\mathrm{TcO}_{2}$ (cr), $\mathrm{TcO}_{2} \cdot \mathrm{nH}_{2} \mathrm{O}, \mathrm{TcO}(\mathrm{OH})_{2}$, and $\mathrm{Tc}(\mathrm{OH})_{4}$, have been proposed by various investigators. This solid is considered to be essentially amorphous (Rard et al. 1999). The authors of this report know of no studies that have compared the X-ray diffraction characteristics of $\mathrm{TcO}_{2} \cdot \mathrm{nH}_{2} \mathrm{O}$ samples formed by different abiotic and biotic processes. Meyer et al. (1991) studied the solubility of $\mathrm{TcO}_{2} \cdot \mathrm{nH}_{2} \mathrm{O}$ over the $\mathrm{pH}$ range 1 to 10 . The hydration numbers determined by Meyer et al. (1991) for their technetium solids ranged from 0.44 to 4.22 and from 1.38 to 1.81 for solids precipitated from acid and basic solutions, respectively. For the formula used for $\mathrm{TcO}_{2} \cdot \mathrm{nH}_{2} \mathrm{O}$, Rard et al. (1999) selected 1.6, which corresponds to the value suggested by Meyer et al. (1991). As Rard et al (1999) noted, the exact value for the hydration number has no effect on the solution chemistry and predicted environmental mobility of dissolved technetium.

Figure 3.10 shows the Eh-pH conditions under which an aqueous solution containing $1 \times 10^{-7} \mathrm{~mol} / \mathrm{L}$ total dissolved technetium calculates to be oversaturated with technetium solids. In the Eh-pH region defined by the tan area in Figure 3.10, the solid $\mathrm{TcO}_{2} \cdot 2 \mathrm{H}_{2} \mathrm{O}$ calculates as oversaturated based on the available thermodynamic data and may precipitate at these Eh-pH conditions to limit the maximum concentration of dissolved technetium in sediments under these redox potentials. Concentrations less than about $1 \times 10^{-7.5} \mathrm{~mol} / \mathrm{L}$ total dissolved technetium are below the predicted solubility of $\mathrm{TcO}_{2} \cdot 2 \mathrm{H}_{2} \mathrm{O}(\mathrm{am})$. Thus, the Eh-pH figure was generated using the higher concentration of ${ }^{99} \mathrm{Tc}\left[1 \times 10^{-7} \mathrm{~mol} / \mathrm{L}\right]$ so that a stability field for the solid would be shown.

The solubility of technetium in contact with hydrated $\mathrm{TcO}_{2}$ was investigated by Pilkington (1990), who found that $\mathrm{pH}$ had little effect on measured solubility of technetium over the $\mathrm{pH}$ range of 1 to 12.5. The presence of organic materials increased the measured solubility of technetium by a factor of 10 , indicating that complexation between dissolved organic materials and technetium is important. Wildung et al. (1986) suggested that low molecular-weight organic ligands may increase the solubility of reduced forms of technetium, whereas complexation with the high molecular-weight organic ligands, particularly insoluble organic ligands, may lead to precipitation. Schulte and Scoppa (1987) showed that Tc(IV) had a strong tendency to coordinate with ligands containing highly polar groups and negatively charged ligands. 


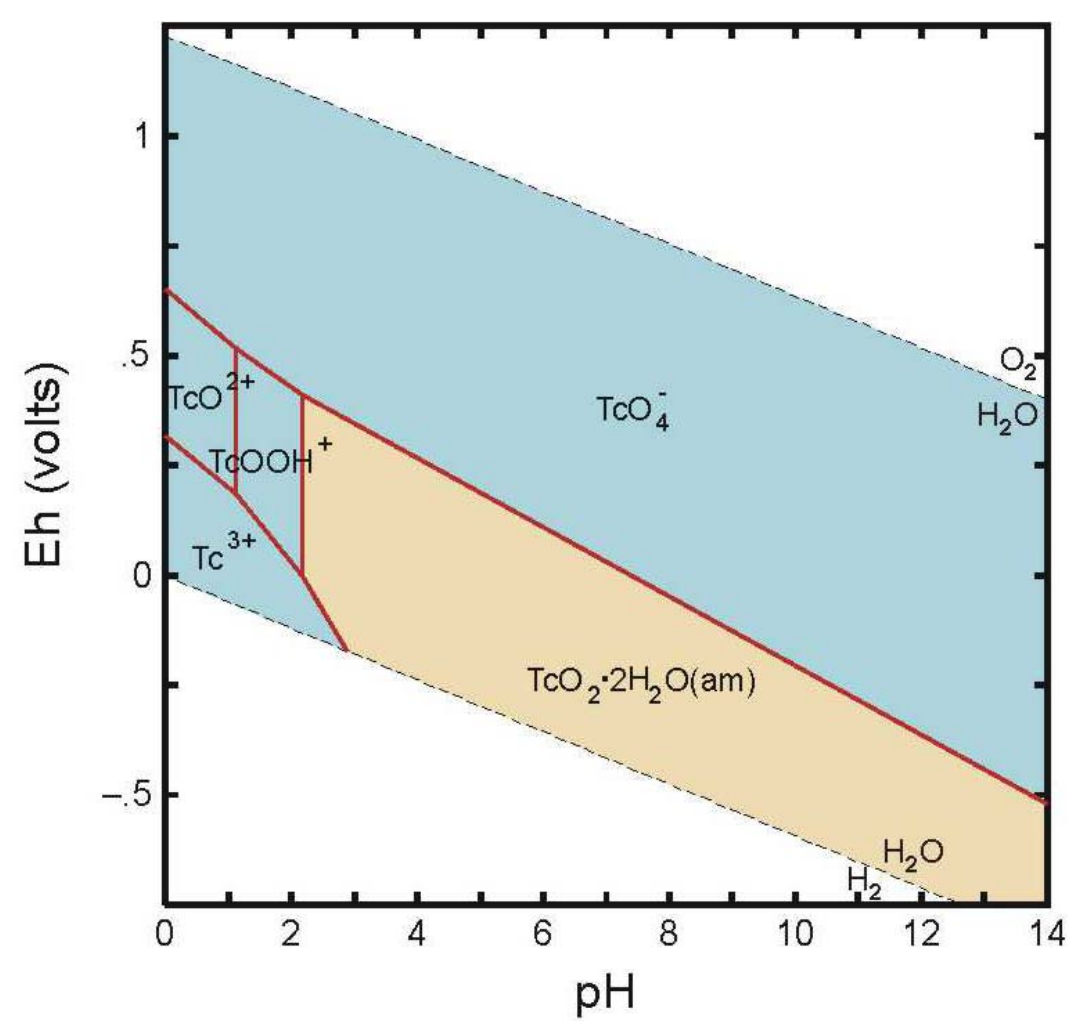

Figure 3.10. Stability Diagram Showing Eh-pH Region (tan colored) that Calculates to be Oversaturated with Respect to the Solubility of Technetium Solids. (Diagram was calculated at a total concentration of $1 \times 10^{-7} \mathrm{~mol} / \mathrm{L}$ dissolved technetium at $25^{\circ} \mathrm{C}$.)

In reduced iron-sulfide systems, Tc(VII) can be reduced to Tc(IV) with coprecipitation with FeS solid (mackinawite) (Wharton et al. 2000; Livens et al. 2004). Due to the poorly ordered structures of the precipitates, Wharton et al. (2000) were not able to confirm whether Tc(IV) was incorporated in the structure of the FeS solid or precipitated as a distinct technetium solid phase. Their X-ray absorption spectroscopy (XAS) results suggest that the reduction of technetium at these conditions may have precipitated a $\mathrm{TcS}_{2}$ like phase (Wharton et al. 2000). The more recent results of Livens et al. (2004) show that the reaction product of $\mathrm{Tc}(\mathrm{VII})$ on the surface of mackinawite is reduced to oxidation state +4 and forms a $\mathrm{TcS}_{2}$-like species. Upon oxidation in air, the mackinawite forms goethite $(\mathrm{FeOOH})$, and the technetium remains in the reduced +4 oxidation state but in an oxide rather than sulfide form.

Results recently published by Mattigod et al. $(2002,2003)^{(\mathrm{a})}$ from waste glass weathering studies conducted in support of the ILAW/IDF PA suggest that under oxic conditions, secondary products that form from the weathering of ILAW waste glasses may incorporate small masses of anionic contaminants, such as iodide $\left(\mathrm{I}^{-}\right)$, selenate $\left(\mathrm{SeO}_{4}{ }^{2-}\right)$, and pertechnetate $\left(\mathrm{TcO}_{4}{ }^{2-}\right)$, making them resistant to remobilization. The studies of Mattigod et al. are discussed in more detail in Section 3.2.2. Mattigod et al. (2003) ${ }^{(\mathrm{a})}$ completed experiments with radionuclide-spiked groundwater and determined that $\sim<1$ to $12 \%$ of ${ }^{99} \mathrm{Tc}$ was sorbed with reaction products that formed from the leaching of waste glasses. In desorption tests,

(a) Mattigod SV, RJ Serne, BP McGrail, VL LeGore, and KE Parker. 2004. "Sequestration of radionuclides $\left({ }^{125} \mathrm{I}\right.$, ${ }^{54} \mathrm{Se},{ }^{99} \mathrm{Tc}$ ) in secondary crystalline minerals resulting from chemical weathering of selected waste glasses." To be submitted to Radiochimica Acta. 
Mattigod et al. determined that up to $67 \%$ of the sorbed ${ }^{99} \mathrm{Tc}$ in the weathered LAWBP 1 and LAWA44 glasses did not easily desorb from the weathering glasses when contacted with groundwater-like solutions. Until this apparent coprecipitation (or specific adsorption) of $\mathrm{I}^{-}, \mathrm{SeO}_{4}{ }^{2-}$, and $\mathrm{TcO}_{4}{ }^{2-}$ in waste glass weathering products is further quantified, this process is not included in transport calculations or the geochemical data package for the 2005 IDF ILAW PA. This will build a degree of conservatism into the performance assessment calculations that could be dealt with (removed) if quantitative data for the extent of weathering product formation per unit mass of waste glass and the mass of coprecipitated contaminants of interest in these weathering products become available at a later date.

\subsubsection{Sorption}

Numerous studies on the sorption of technetium on sediments, soils, pure minerals, oxide phases, and crushed rock materials have been conducted. An extensive review of these studies is presented in EPA (2004). These studies consist primarily of measurements of $\mathrm{K}_{\mathrm{d}}$ values for Tc(VII). The adsorption of $\mathrm{Tc}(\mathrm{VII})$ oxyanion $\mathrm{TcO}_{4}{ }^{-}$is expected to be very low to zero, i.e., $\mathrm{K}_{\mathrm{d}}$ values of $\approx 0 \mathrm{~mL} / \mathrm{g}$ at near-neutral and basic $\mathrm{pH}$ conditions and to increase when $\mathrm{pH}$ values decrease to less than 5 .

Several studies have shown that retention of technetium by solid phases is related to the physicochemical properties of the solid phase (reviewed by Ames and Rai [1978], Gu and Schulz [1991]). These studies indicate that systems containing low amounts of clay, organic carbon, and aluminum/iron oxides show very little adsorption. Bowen (1966) reported that, in oxic conditions, $90 \%$ of added $\mathrm{TcO}_{4}{ }^{-}$was readily extractable from soils and assumed to remain in solution either as the free ion or weakly adsorbed to ion-exchange sites. Similarly, Wildung et al. (1977) reported that under oxic conditions, 78 to $88 \%$ of the $\mathrm{TcO}_{4}{ }^{-}$added to soil could be extracted easily 30 days after application. Under anaerobic conditions, Cataldo et al. (1978) reported that technetium removal from solution by soils could exceed $97 \%$ in two to five weeks.

The $K_{d}$ values for $\mathrm{Tc}(\mathrm{VII})$ sorbed on sediments high in organic matter can be large. In a study of seven mineral soils and 27 organic soils, Sheppard et al. (1990) reported that, in addition to the redox status, the organic matter content of soils plays an important role in technetium sorption. Evidence of the complexation between organic materials and technetium has also been presented by Van Loon et al. (1986), who indicate that such complexes can be readily synthesized by chemical reduction of pertechnetate in the presence of organic matter. Wildung et al. (1974) determined that the sorption of $\mathrm{TcO}_{4}{ }^{-}$is positively correlated to the organic carbon content of soils, but studies of the effect that organic material has on the sorption of Tc(VII) in soils are limited.

Reduced technetium precipitates or organic matter-technetium complexes are not resolubilized by the chelating agents, EDTA and DTPA, which are known to form stable technetium complexes (Stalmans et al. 1986). This would indicate that EDTA and DTPA complexes are not as strong as the technetium organic matter complexes, suggesting that naturally occurring organic matter may play a significant role in technetium transport by forming relatively stable technetium complexes. Whether these complexes are soluble or insoluble depends on the size of the organic ligand. It is not known whether the organic matter-Tc(IV) complexation reaction can favorably compete with $\mathrm{Tc}(\mathrm{IV})$ hydrolysis reactions. 
Um and Serne ${ }^{(a)}$ completed a series of batch and column adsorption studies of ${ }^{99} \mathrm{Tc},{ }^{129} \mathrm{I},{ }^{79} \mathrm{Se}$, and ${ }^{90} \mathrm{Sr}$ on Hanford sediments collected from an ILAW borehole (C3177) at the 200 East Area on the Hanford Site. The batch sorption experiments were conducted using both uncontaminated Hanford groundwater and simulated glass leachates spiked with individual radionuclides. Um and Serne reported $\mathrm{K}_{\mathrm{d}}$ values for the adsorption of ${ }^{99} \mathrm{Tc}$ on $\mathrm{C} 3177$ sediment from $110 \mathrm{ft}$ below ground surface of $0.00 \pm 0.00(\mathrm{pH} 7.6)$ and $0.00 \pm 0.00$ ( $\mathrm{pH} 9.0$ ), respectively, for Hanford groundwater and the simulated glass leachate. These results indicate no adsorption affinity for ${ }^{99} \mathrm{Tc}$ on these sediments at these geochemical conditions. Um and Serne conclude that these adsorption data corroborate values obtained for sediments collected in the past from nearby locations and for generic aqueous solutions such as regional groundwater. They also noted that the new results provide more technical defensibility for past ILAW/IDF performance assessment predictions that did not use site-specific sediments and/or leachates.

As described previously (Section 3.2.3), Kaplan et al. (2003) studied the influence of $\mathrm{NaOH}$ solutions, a simplified surrogate for glass leachate on the hydraulic, physical, mineralogical, and sorptive properties of Hanford sediment. The study also included a series of batch sorption tests with Warden soil that Kaplan et al. (2003) used to measure the $K_{d}$ values for cesium, strontium, iodide, selenate, and pertechnetate in soils treated with caustic solutions for up to 360 days. Kaplan et al. did not detect any appreciable adsorption for iodide, selenate, or pertechnetate (i.e., $\mathrm{K}_{\mathrm{d}}=0$ ) on sediment contacted with $\mathrm{NaOH}$ solutions. Section 3.2.3 has a more complete summary of results from Kaplan et al. (2003).

Cantrell et al. (2003) compiled the $\mathrm{K}_{\mathrm{d}}$ values measured with Hanford sediment for radionuclides and contaminants of environmental concern to the vadose zone and groundwater at Hanford. Table 15 in Cantrell et al. (2003) lists the $\mathrm{K}_{d}$ values determined for Tc(VII) using Hanford sediment. The data compiled by Cantrell et al. indicate that $\mathrm{Tc}(\mathrm{VII})$ adsorption is low under nearly all conditions relevant to the Hanford vadose zone and upper unconfined aquifer with $\mathrm{K}_{\mathrm{d}}$ values ranging from zero to a high of approximately $1 \mathrm{~mL} / \mathrm{g}$. They note that the Tc(VII) $\mathrm{K}_{\mathrm{d}}$ values at the upper end of this range also have large standard deviations. $\mathrm{K}_{\mathrm{d}}$ values approaching $1 \mathrm{~mL} / \mathrm{g}$ appeared to be most representative in one study, but this was not substantiated by $\mathrm{K}_{\mathrm{d}}$ values determined in other studies. Cantrell et al. (2003) concluded that, under normal Hanford conditions, zero is the most appropriate $\mathrm{K}_{\mathrm{d}}$ value for $\mathrm{Tc}(\mathrm{VII})$, and 0.0 to $0.1 \mathrm{~mL} / \mathrm{g}$ is the best estimate for the range for $\mathrm{Tc}(\mathrm{VI}) \mathrm{K}_{\mathrm{d}}$ values. At the higher $\mathrm{pH}$ generated by glass leaching, the $\mathrm{K}_{\mathrm{d}}$ for pertechnetate is even lower than for circumneutral $\mathrm{pH}$ groundwaters. Thus the $\mathrm{K}_{\mathrm{d}}$ for $\mathrm{Tc}(\mathrm{VII})$ in the ILAW glass-dominated IDF near-field vadose zone is best fixed as $0 \mathrm{~mL} / \mathrm{g}$.

\subsection{Uranium}

The geochemical behavior of uranium has received extensive study due to the importance of uranium as an energy source and geochronology indicator. The uranium isotopes of interest in waste disposal and their respective half-lives include ${ }^{233} \mathrm{U}, 1.592 \times 10^{5}$ years; ${ }^{234} \mathrm{U}, 2.455 \times 10^{5}$ years; ${ }^{235} \mathrm{U}, 7.04 \times 10^{8}$ years; ${ }^{236} \mathrm{U}, 2.342 \times 10^{7}$ years; and ${ }^{238} \mathrm{U}, 4.468 \times 10^{9}$ years (Tuli 2004). There have been several published reviews of the geochemical behavior of uranium. Langmuir (1978) and an updated discussion in Langmuir (1997) are particularly noteworthy. In 1999, an extensive compilation of detailed reviews on the mineralogical, geochemical, and environmental behavior of uranium was published in Burns and Finch (1999). This compilation is especially valuable because of the detail and recentness of the included papers, the

(a) Um W and RJ Serne. 2004. "Sorption and Transport Behavior of Radionuclides in the Proposed Low-Level Radioactive Waste Disposal Facility at the Hanford Site, Washington." Submitted to Radiochimica Acta. 
extensive list of references, and the wide range of topics covered. Topics covered in this compilation of papers include the reviews of the mineralogy and paragenesis of uranium minerals; the genesis of uranium ore deposits; the geochemical behavior of uranium in natural fluids; environmental aspects of uranium geochemistry such as microbial effects, groundwater contamination, and nuclear waste disposal; and analytical techniques for characterization of uranium-bearing phases (Burns and Finch 1999).

\subsubsection{Oxidation States and Aqueous Speciation}

Uranium can exist in the $+3,+4,+5$, and +6 oxidation states in aqueous environments. Uranium(VI), i.e., uranyl, $\mathrm{UO}_{2}{ }^{2+}$, and $\mathrm{U}(\mathrm{IV})$ are the most common oxidation states of uranium in natural environments. Uranium exists in the +6 oxidation state under oxidizing to mildly reducing environments. Uranium(IV) is stable under reducing conditions and considered relatively immobile because U(IV) forms sparingly soluble minerals such as uraninite $\left(\mathrm{UO}_{2}\right)$. Dissolved $\mathrm{U}(\mathrm{III})$ easily oxidizes to $\mathrm{U}(\mathrm{IV})$ under most reducing conditions found in nature. The $\mathrm{U}(\mathrm{V})$ aqueous species $\left(\mathrm{UO}_{2}{ }^{+}\right)$readily disproportionates to $\mathrm{U}(\mathrm{IV})$ and $\mathrm{U}(\mathrm{VI})$ such that it is a transient species in nature.

As with the redox of technetium, the reduction of $U(V I)$ to $U(I V)$ by abiotic and biotic processes has received considerable attention recently because the oxidation state of uranium has a significant effect on its mobility in waste streams and the natural environment. These reaction processes are the basis for certain remediation technologies such as permeable barriers composed of zero-valent iron particles, i.e., metallic iron or sodium-dithionite-reduced soils. Microbial reduction of U(VI) has also been suggested as a potential mechanism for removal of uranium from contaminated waters and soils, (e.g., Lovley 1993, 1995). Suzuki and Banfield (1999) provide a detailed review and extensive reference list on the interactions between uranium and microorganisms.

Grenthe et al. (1992) and Guillaumont et al. (2003) have published an extensive series of critical reviews of the thermodynamics of uranium. These references are the most detailed review completed to date of the available thermodynamic data for inorganic uranium compounds.

Dissolved U(VI) tends to form strong complexes with inorganic oxygen-containing ligands such as hydroxide, carbonate, and phosphate. Aqueous $\mathrm{UO}_{2}{ }^{2+}$ hydrolyzes to form a number of aqueous hydroxo complexes, including $\mathrm{UO}_{2} \mathrm{OH}^{+},\left(\mathrm{UO}_{2}\right)_{2}(\mathrm{OH})_{2}{ }^{2+},\left(\mathrm{UO}_{2}\right)_{3}(\mathrm{OH})_{5}{ }^{+}$, and $\mathrm{UO}_{2}(\mathrm{OH})_{3}{ }^{-}$. In aqueous systems equilibrated with air or higher $\mathrm{pCO}_{2}$ and at near-neutral to high $\mathrm{pH}$, carbonate complexes $\left[\mathrm{UO}_{2} \mathrm{CO}_{3}{ }^{0}(\mathrm{aq})\right.$, $\left.\mathrm{UO}_{2}\left(\mathrm{CO}_{3}\right)_{2}{ }^{2-}, \mathrm{UO}_{2}\left(\mathrm{CO}_{3}\right)_{3}{ }^{4-}\right]$ will dominate, but at lower $\mathrm{pH}$ the hydrolysis species will dominate as $\mathrm{CO}_{2}$ solubility decreases. The Eh-pH diagram in Figure 3.11 shows the dominant aqueous species calculated for dissolved uranium at $25^{\circ} \mathrm{C}$ using concentrations of $1 \times 10^{-8} \mathrm{~mol} / \mathrm{L}$ total dissolved uranium, $1 \times 10^{-3} \mathrm{~mol} / \mathrm{L}$ total dissolved carbonate, and $5 \times 10^{-6} \mathrm{~mol} / \mathrm{L}$ total dissolved fluoride. The aqueous speciation of U(VI) in carbonate-containing water at near-neutral and basic higher $\mathrm{pH}$ values is dominated by a series of strong anionic aqueous carbonate complexes [e.g., $\mathrm{UO}_{2} \mathrm{CO}_{3}{ }^{0}(\mathrm{aq}), \mathrm{UO}_{2}\left(\mathrm{CO}_{3}\right)_{2}{ }^{2-}$, and $\mathrm{UO}_{2}\left(\mathrm{CO}_{3}\right)_{3}{ }^{4-}$. Because anions do not readily adsorb to mineral surfaces at basic $\mathrm{pH}$ conditions, formation of anionic $\mathrm{U}(\mathrm{VI})$ carbonate complexes at $\mathrm{pH}$ values greater than 6 results in increased U(VI) solubility, decreased U(VI) adsorption, and increased mobility of uranium. Because of the high hydroxide, high carbonate, and low organic concentrations expected in both the near and far fields of the Hanford IDF site, dissolved U(VI) is likely to exist as a complexed carbonate and/or, to a lesser extent, as a hydroxide-complexed species. The Hanford vadose zone and upper unconfined aquifer environments contain adequate carbonate 


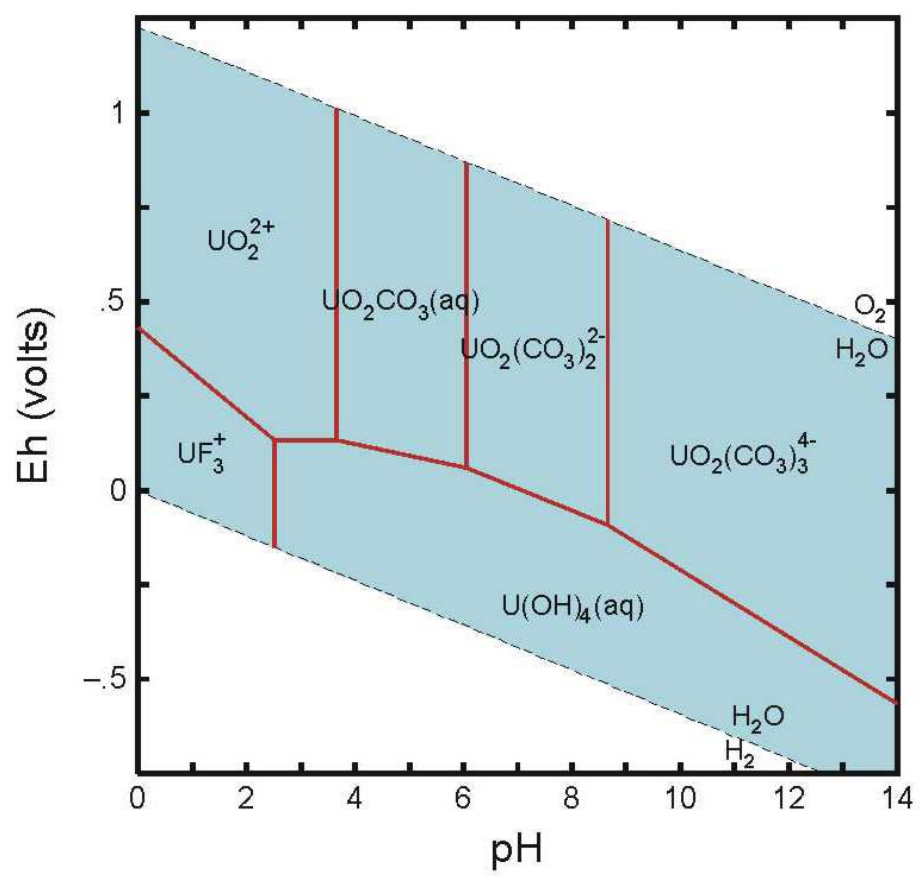

Figure 3.11. Eh-pH Diagram Showing Dominant Aqueous Species of Uranium. (Diagram calculated at a total concentration of $1 \times 10^{-8} \mathrm{~mol} / \mathrm{L}$ dissolved uranium at $25^{\circ} \mathrm{C}$ diagram.)

concentrations for these uranyl carbonate complexes to dominate the aqueous speciation of uranium. In fact, direct verification of the uranyl carbonate dominance in vadose zone pore waters from borehole 299E33-45 is presented in Knepp (2002, Appendix D).

Recent studies indicate that a dissolved calcium uranyl carbonate complex may also have an important effect on the geochemical behavior of U(VI) in calcium-rich aqueous systems at near-neutral to basic pH conditions. Bernhard et al. $(1996,2001)$ used spectroscopic techniques to investigate aqueous complexation in the system $\mathrm{Ca}^{2+}-\mathrm{U}(\mathrm{VI})-\mathrm{CO}_{3}{ }^{2-}-\mathrm{H}_{2} \mathrm{O}$. The results of their series of studies provide evidence for the formation of a strong, uncharged aqueous complex, $\mathrm{Ca}_{2} \mathrm{UO}_{2}\left(\mathrm{CO}_{3}\right)_{3}{ }^{0}(\mathrm{aq})$. Aqueous speciation calculations based on stability constants published by Kalmykov and Choppin (2000) and Bernhard et al. (2001) for the formation of $\mathrm{Ca}_{2} \mathrm{UO}_{2}\left(\mathrm{CO}_{3}\right)_{3}{ }^{0}(\mathrm{aq})$ indicate that this species would be a predominant species under oxidizing conditions from $\mathrm{pH} 6$ to 10 in calcium-rich waters containing dissolved U(VI). Because studies by Kalmykov and Choppin (2000) and Bernhard et al. (2001) are so recent, inclusion of the complex $\left.\mathrm{Ca}_{2} \mathrm{UO}_{2}\left(\mathrm{CO}_{3}\right)_{3}{ }^{0} \mathrm{aq}\right)$ is only recently showing up in published aqueous speciation calculations for U(VI) (e.g., Brooks et al. 2003). Caution should be exercised when including $\mathrm{Ca}_{2} \mathrm{UO}_{2}\left(\mathrm{CO}_{3}\right)_{3}{ }^{0}$ (aq) and its stability constant in aqueous U(VI) speciation and solubility calculations. In the detailed critical review of thermodynamic constants for key radionuclides, Guillaumont et al. (2003) did not accept the formation constants published for the aqueous complex $\mathrm{Ca}_{2} \mathrm{UO}_{2}\left(\mathrm{CO}_{3}\right)_{3}{ }^{0}$ (aq). Guillaumont et al. (2003) believed that the published studies provided excellent evidence for complex formation between cations ( $\mathrm{such}$ as $\mathrm{Ca}^{2+}$ ) and $\mathrm{UO}_{2}\left(\mathrm{CO}_{3}\right)_{3}{ }^{4-}$, but indicated that the constants listed in the literature had a large uncertainty and likely overpredicted the strength and stability of $\left.\mathrm{Ca}_{2} \mathrm{UO}_{2}\left(\mathrm{CO}_{3}\right)_{3}{ }^{0} \mathrm{aq}\right)$. A detailed discussion of the reasons for their decision is given in Guillaumont et al. (2003). 
Phosphate- $\mathrm{UO}_{2}{ }^{2+}$ complexes such as $\mathrm{UO}_{2} \mathrm{HPO}_{4}{ }^{0}(\mathrm{aq})$ and $\mathrm{UO}_{2} \mathrm{PO}_{4}{ }^{-}$could be important in aqueous systems with a pH between 6 and 9 when the total concentration ratio $\left(\mathrm{PO}_{4}{ }^{3-}{ }_{\text {Total }} / \mathrm{CO}_{3}{ }^{2-}\right)_{\text {total }}$ is $\geq 10^{-1}$ (Sandino and Bruno 1992; Langmuir 1978). Complexes with $\mathrm{SO}_{4}{ }^{2-}, \mathrm{F}^{-}$and possibly $\mathrm{Cl}^{-}$are potentially important U(VI) species where concentrations of these anions are high, but their stability is considerably less than that of the carbonate and phosphate complexes (Grenthe et al. 1992).

Under reducing conditions, the speciation of U(IV) is dominated by the neutral aqueous species $\mathrm{U}(\mathrm{OH})_{4}{ }^{0}$ (aq) at $\mathrm{pH}$ values greater than 2 . Complexation of $\mathrm{U}(\mathrm{IV})$ with natural organic humic and fulvic acids has been suggested as an important process ( $\log \mathrm{K}=12$ to 16; Birch and Bachofen 1990). Hence, U(IV) could form stable organic complexes, increasing the solubility of the U(IV). In general, U(IV) species form stronger organic complexes than do the U(VI) species (Birch and Bachofen 1990).

\subsubsection{Precipitation and Coprecipitation}

Given the omnipresence of carbonate in Hanford vadose zone and unconfined aquifer system and the formation of strong aqueous $\mathrm{U}(\mathrm{VI})$ carbonate complexes, precipitation or coprecipitation of a solid phase likely will not control the mobility of U(VI) under oxidizing conditions in the vadose zone areas unaffected by waste discharges and the unconfined aquifer at the Hanford Site. If the near-field conditions become sufficiently reducing to maintain dissolved uranium in the +4 oxidation state, $U(I V)$ readily precipitates as sparingly soluble minerals such as uraninite $\left(\mathrm{UO}_{2}\right)$. Under such conditions, uranium is therefore considered relatively immobile. Figure 3.12 shows the Eh-pH region ( $\tan$ area) in which

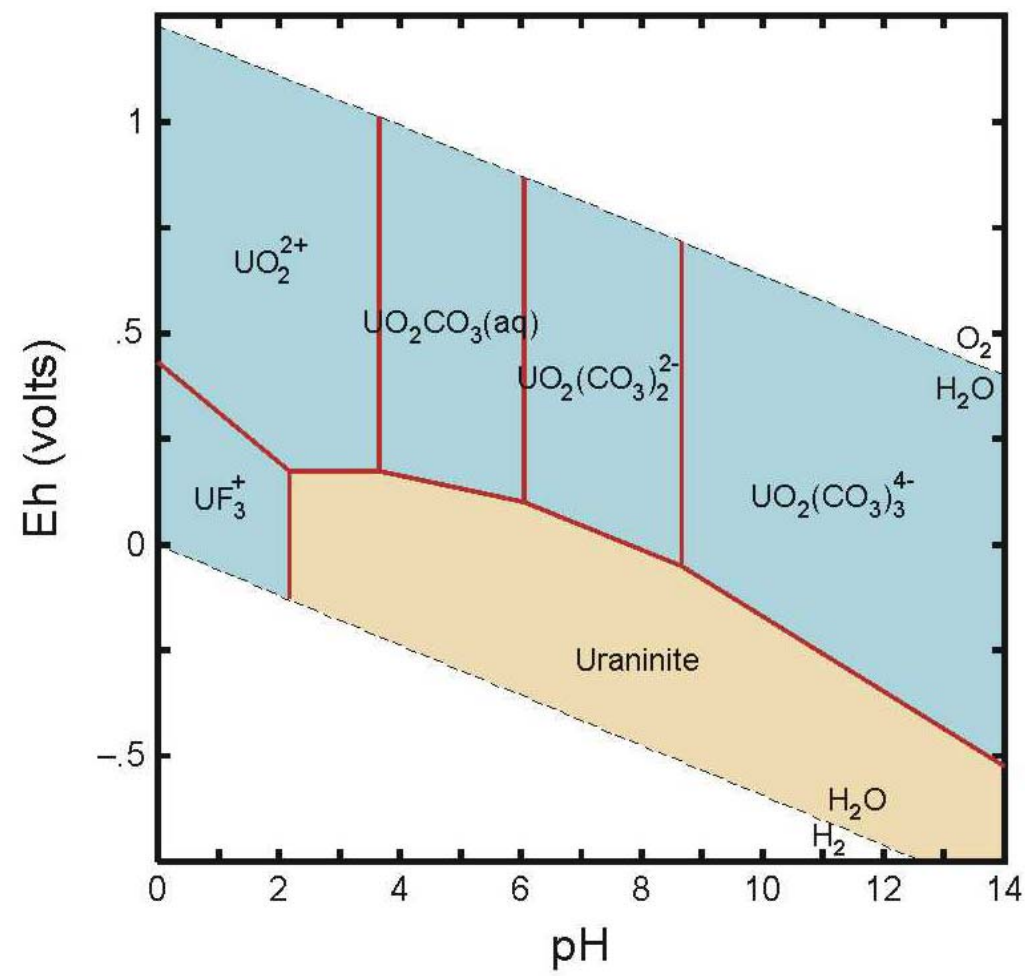

Figure 3.12. Stability Diagram Showing Eh-pH Region (tan colored) that Calculates as Oversaturated with Respect to the Solubility of Uraninite $\left(\mathrm{UO}_{2}\right)$. (Diagram was calculated at a total concentration of $1 \times 10^{-8} \mathrm{~mol} / \mathrm{L}$ dissolved uranium at $25^{\circ} \mathrm{C}$.) 
uraninite $\left(\mathrm{UO}_{2}\right)$ calculates to be oversaturated for a total concentration of $1 \times 10^{-8} \mathrm{~mol} / \mathrm{L}$ dissolved uranium based on the available thermodynamic data. In geologic systems represented by these Eh-pH conditions (tan area in Figure 3.12), uraninite may precipitate and limit the maximum concentration of dissolved uranium to $1 \times 10^{-8} \mathrm{~mol} / \mathrm{L}$ or less in those sediments.

Precipitation and coprecipitation processes may also be important for UVI) for some oxidizing environmental conditions. Depending on the geochemical conditions, several different uranium coprecipitates may form depending on the pore fluid chemistry (Finch and Murakami 1999; Falck 1991; Frondel 1958). For example, solubility processes may be particularly important for U(VI) under oxidizing conditions in some uranium-contaminated sediments that are partially saturated (or dry) between periods of recharge or the pore fluids become isolated in micropores in the minerals. Under these conditions, the concentration of uranium in the residue pore fluids may exceed the solubility limits for U(VI)-containing minerals and/or coprecipitate with other minerals such as iron oxides, or undergo coupled sorption-reduction of aqueous U(VI) by Fe(II)-containing minerals. Potentially important mineral solubility controls for $\mathrm{U}(\mathrm{VI})$ include compreignacite $\left(\mathrm{K}_{2} \mathrm{U}_{6} \mathrm{O}_{19} \cdot 11 \mathrm{H}_{2} \mathrm{O}\right)$, uranophane $\left[\mathrm{Ca}\left(\mathrm{UO}_{2}\right)_{2}\left(\mathrm{SiO}_{3}\right)_{2}(\mathrm{OH})_{2} \cdot 5 \mathrm{H}_{2} \mathrm{O}\right]$, boltwoodite $\left[\mathrm{K}\left(\mathrm{H}_{3} \mathrm{O}\right) \mathrm{UO}_{2}\left(\mathrm{SiO}_{4}\right) \cdot 1.5 \mathrm{H}_{2} \mathrm{O}\right]$, sklodowskite $\left[\mathrm{Mg}\left(\mathrm{UO}_{2}\right)_{2}\left(\mathrm{SiO}_{3}\right)_{2}(\mathrm{OH})_{2} \cdot 5 \mathrm{H}_{2} \mathrm{O}\right]$, becquerelite $\left(\mathrm{CaU}_{6} \mathrm{O}_{19} \cdot 10 \mathrm{H}_{2} \mathrm{O}\right)$, carnotite $\left[\left(\mathrm{K}_{2}\left(\mathrm{UO}_{2}\right)_{2}\left(\mathrm{VO}_{4}\right)_{2} \cdot 3 \mathrm{H}_{2} \mathrm{O}\right]\right.$, schoepite $\left(\mathrm{UO}_{3} \cdot 2 \mathrm{H}_{2} \mathrm{O}\right)$, rutherfordine $\left(\mathrm{UO}_{2} \mathrm{CO}_{3}\right)$, tyuyamunite $\left[\mathrm{Ca}\left(\mathrm{UO}_{2}\right)_{2}\left(\mathrm{VO}_{4}\right)_{2} \cdot 5-8 \mathrm{H}_{2} \mathrm{O}\right]$, autunite ${ }^{(\mathrm{a})}$ $\left[\mathrm{Ca}\left(\mathrm{UO}_{2}\right)_{2}\left(\mathrm{PO}_{4}\right)_{2} \cdot 10-12 \mathrm{H}_{2} \mathrm{O}\right]$, and potassium autunite $\left[\mathrm{K}_{2}\left(\mathrm{UO}_{2}\right)_{2}\left(\mathrm{PO}_{4}\right)_{2} \cdot 10-12 \mathrm{H}_{2} \mathrm{O}\right]$ (Langmuir 1997).

Uranium is also sequestered in the glass weathering products formed in short-term laboratory experiments such that coprecipitation reactions in the glass vault should be considered in the 2005 IDF PA if quantitative data are available. Besides determining the loading capacity of the weathering products for uranium and other contaminants, the long-term stability of weathering products needs to be established.

Several characterization studies at DOE sites such as Hanford, Fernald, Oak Ridge, and Savannah River suggest that sediments and soils contaminated from disposal or spills of uranium-containing liquid wastes at these sites have uranium-containing minerals or coprecipitates present (e.g., Delegard et al. 1986 ; Serne et al. 2002a ; Zachara et al. 2002a; Catalano et al. 2004 ; Buck et al. 1994, 1996 ; Morris et al. 1996; Roh et al. 2000; Bertsch et al. 1994; Hunter and Bertsch 1998). The studies related to Hanford, some of which are ongoing, are described below. Other studies pertaining to the characterization of uranium contamination in soils at other DOE sites that may be of interest to the reader include those pertaining to Fernald (Buck 1994, 1996; Morris et al. 1996), Oak Ridge (Roh et al. 2000), and Savannah River Sites (Bertsch et al. 1994; Hunter and Bertsch 1998).

Delegard et al. (1986) investigated the use of an ion exchange-based technique for removing dissolved uranium from contaminated groundwater underlying the then newly activated 216-U-16 and the retired 216-U-1 and 216-U-2 liquid waste disposal cribs in the 200W Separations Areas on the Hanford Site. Analysis of groundwater samples from area wells near these cribs indicated that the dissolved uranium was present as poorly adsorbing, aqueous anionic U(VI) carbonate complexes such as $\mathrm{UO}_{2}\left(\mathrm{CO}_{3}\right)_{2}{ }^{2-}$ (see speciation in Figure 3.11). X-ray diffraction (XRD) analysis of sediment samples from well 299-W19-11 indicated that the mineralogy of the sediments consisted primarily of quartz, illite, and feldspar. Sediment taken at a depth of $10.8 \mathrm{~m}$ from well 299-W19-11 was also found to contain uranium

(a) Autunite often refers to an entire group of secondary $\mathrm{U}(\mathrm{VI})$ minerals of the general formula $\mathrm{R}^{2+}\left(\mathrm{UO}_{2}\right)_{2}\left(\mathrm{XO}_{4}\right)_{2} \cdot n \mathrm{H}_{2} \mathrm{O}$, where $\mathrm{R}=\mathrm{Ca}, \mathrm{Cu}, \mathrm{Mg}, \mathrm{Ba}, \mathrm{Na}_{2}$, and other metals, and $\mathrm{XO}_{4}=\mathrm{PO}_{4}$ or $\mathrm{AsO}_{4}$. 
precipitates in the form of meta-autunite. At the time of the studies by Delegard et al. (1986), the uranium in these sediments had been remobilized by water flow resulting from nearby disposal of cooling water.

Serne et al. (2002a) recently conducted characterization, leaching, and adsorption/desorption studies of uranium-contaminated sediments collected at near-surface waste sites in the 300 Area at the Hanford Site. Scanning electron microscopy and molecular probe analyses indicate that uranium in the soil samples is likely present as coprecipitate and/or discrete uranium particles. The detailed analyses completed by Serne and coworkers to date have not determined the exact identification of the uranium phases. Their analyses indicate that uranium is present in the +6 valence state. The molecular probe data suggest that the crystalline uranium phases are likely clarkeite $\left[(\mathrm{Na}, \mathrm{Ca}, \mathrm{Pb})_{2}\left(\mathrm{UO}_{2}\right) \mathrm{O}(\mathrm{OH}) 0-1 \mathrm{H}_{2} \mathrm{O}\right]$ or uranophane. Extended X-ray absorption fine structure (EXAFS) analyses suggest that the U(VI)-containing phases are likely uranyl phosphates and/or silicates based on the interatomic distance considerations. Laser fluorescence spectroscopy measurements indicate that the uranium-contaminated sediments do not contain uranyl phosphates. The investigators are continuing these analyses and their interpretation of the data to resolve the differences in the results from EXAFS and laser fluorescence spectroscopy.

A series of characterization studies by Zachara et al. (2002a) (and references cited in this paragraph) was conducted to identify the form and oxidation state of uranium in samples of waste-contaminated sediment from borehole 299-E33-45, which was drilled through the waste plume east of Hanford Tank 241-BX-102. These studies by Zachara et al. are being published in technical journals. The results of the studies indicate that uranium precipitated in the +6 valence state and formed discrete particles or particle aggregates in the contaminated vadose zone sediments. McKinley et al. (2002) ${ }^{(\mathrm{a})}$ analyzed thin sections of the contaminated sediments from BX-102 core using X-ray microprobe (XMP), X-ray absorption fine structure (XAFS), X-ray absorption near-edge structure (XANES), electron microprobe (EMP), and SEM. Their results showed that the uranium particles were typically 1 to $3 \mu \mathrm{m}$ in diameter and occasionally formed radiating clusters of acicular crystals. McKinley et al. (2002) $)^{(a)}$ found that the uranium particles occurred in microfractures in the sediment particles and did not exhibit any association with any specific sediment mineral phase(s) that could have been a surface catalyst for their precipitation. Their chemical analyses indicated that the uranium particles were composed of uranium, silicon, oxygen, sodium, and potassium. McKinley et al. suggest boltwoodite, sodium boltwoodite $\left.\left[(\mathrm{Na}, \mathrm{K})\left(\mathrm{UO}_{2}\right)\left(\mathrm{SiO}_{3} \mathrm{OH}\right) \cdot 1.5 \mathrm{H}_{2} \mathrm{O}\right)\right]$, or weeksite $\left[\mathrm{K}_{1-\mathrm{x}} \mathrm{Na}_{\mathrm{x}}\left(\mathrm{UO}_{2}\right)_{2}\left(\mathrm{Si}_{5} \mathrm{O}_{13}\right) \cdot 4 \mathrm{H}_{2} \mathrm{O}\right]$ as possible identities for the uranium phases in the sediment samples. McKinley et al. propose that uranium precipitation in the microfractures was constrained by diffusion mass transfer and the kinetics for the reactions within this environment were driven by the large reactive surface area relative the enclosed volume of pore fluid.

Catalano et al. $(2002,2004)$ used XAFS spectroscopy, X-ray microdiffraction ( $\mu$ XRD), and microscanning X-ray fluorescence ( $\mu \mathrm{SXRF}$ ) techniques to investigate the speciation and spatial distribution of uranium in samples collected from the BX-102 borehole. Their study did not reveal any evidence for immobilization of uranium by in situ reduction in the sediments. The analyses by Catalano et al. (2004) indicated that the uranium particles were composed of sodium boltwoodite $\left.\left[\mathrm{Na}\left(\mathrm{UO}_{2}\right)\left(\mathrm{SiO}_{3} \mathrm{OH}\right) \cdot 1.5 \mathrm{H}_{2} \mathrm{O}\right)\right]$. Catalano et al. (2004) found no evidence for the presence of any other uranophane group minerals.

(a) McKinley JP, JM Zachara, C Liu, and SC Heald. 2004. "Precipitation of waste uranium as a uranyl silicate in microfactures." Submitted for publication in Science. 
Zachara et al. (2002a) and Wang and coworkers ${ }^{(a)}$ used time-resolved U(VI) laser fluorescence spectroscopy (TRLFS) to characterize the uranium phases present in sediment samples from the BX-102 core. Although an exact match was not found, the results of their TRLFS study indicated that the uranium particles in the microfractures of the sediment particles were a uranyl silicate mineral, such as uranophane, boltwoodite, or soddyite $\left[\left(\mathrm{UO}_{2}\right)_{2} \mathrm{SiO}_{4} \cdot 2 \mathrm{H}_{2} \mathrm{O}\right]$.

Liu et al. ${ }^{(b)}$ conducted dissolution studies of the uranium mineralization identified in the microfractures of mineral particles from the uranium-contaminated sediment collected from the BX-102 borehole. The experiments were completed using sodium, sodium-calcium, and ammonia electrolytes over the $\mathrm{pH}$ range from 7.0 to 9.5 under ambient $\mathrm{CO}_{2}$ pressure. The results of Liu et al. show that the rate and extent of uranium dissolution was affected by mineral solubility, the concentration of dissolved carbonate, and the mass transfer rate within intraparticle regions. Although the concentrations of uranium dissolved by electrolytes below $\mathrm{pH} 8.2$ reached steady state conditions within a month, Liu et al. found that uranium concentrations continued to increase for more than 200 days at $\mathrm{pH}$ values of 9.0 and higher. The results of geochemical modeling calculations by Liu et al. show that the measured steady-state concentrations of dissolved uranium in the dissolution experiments were consistent with the solubility of sodium boltwoodite and/or uranophane. Liu et al. determined that a pseudo-first-order rate constant could be used to predict the dissolution kinetics of the uranyl-silicate mineralization in the three sediments over a range of $\mathrm{pH}$, electrolyte compositions, and bicarbonate/carbonate concentrations used in these experiments. Liu et al. cautioned that except for the case of bounding calculations, use of a single-value $\mathrm{K}_{\mathrm{d}}$ model would be inadequate to predict the sorption and release of uranium from the BX-102 borehole sediments. Liu et al. suggest that geochemical models that incorporate solubility, dissolution kinetics, and mass transfer rates would be required to accurately predict uranium mobility for these environmental conditions.

Investigations funded by the DOE Hanford Science and Technology Program within the Groundwater/Vadose Zone Integration Protection Project are underway to study uranium-contaminated sediments from the 300 Area uranium plume in 300-FF-5 and develop reactive transport modeling approaches to assist with evaluation of alternative remediation approaches. On May 10-11, 2004, a topical workshop was conducted to provide an update of the results from the laboratory investigations of the sediment samples from the 300 Area uranium plume and reactive transport modeling studies. The meeting included participation from the DOE, Environmental Protection Agency, Washington State Department of Ecology, DOE National Laboratories, U.S. Geological Survey, and Hanford stakeholders. The Web site, http://www.hanford.gov/cp/gpp/public/workshops.cfm includes presentations from this workshop.

Presentations on the characterization of 300 Area process pond and vadose-zone sediments from the 300 Area uranium plume and the development of a generalized surface complexation model (discussed in Section 3.7.3) to predict the sorption of uranium in these sediments are briefly discussed here. As these studies are ongoing, the presenters cautioned that the results presented at the workshop presentations are preliminary, continue to be refined and are open to re-interpretation. J. P. McKinley and coworkers at PNNL are using SEM, electron microprobe, and X-ray microprobe (with EXAFS capabilities) analyses to

(a) Wang Z, JM Zachara, PL Gassman, C Liu, O Qafoku, and JG Catalano. 2004. "Fluorescence spectroscopy of U(VI)-silicates and U(VI)-contaminated Hanford sediment." Submitted to Geochimica et Cosmochimica Acta.

(b) Liu C, JM Zachara, O Qafoku, JP McKinley, SM Heald, and Z Wang. 2004. "Dissolution of uranyl microprecipitates from subsurface sediments at the Hanford Site, USA." Submitted to Geochimica et Cosmochimica Acta. 
characterize the nature of uranium contamination in the process pond and vadose sediments from the 300 Area uranium plume. There results to date (taken essentially verbatim from the presentation) are the following:

- For process pond sediments, most of the uranium contamination is associated with a calcium carbonate phase and alumino-silicate mineralization at very low concentration, and particles of discrete reduced phase $\left(\mathrm{UO}_{2}\right)$ were observed imbedded in precipitates.

- In upper vadose sediments, the characterization results were similar to those for the North Pond sediments, with a low-level uranium contamination associated with a calcium carbonate phase and discrete U(VI) oxides segregated in alumino-silicate rind.

- In intermediate vadose sediments, secondary mineral clasts were rare. Low-level uranium contamination is associated with a calcium carbonate phase and discrete $\mathrm{U}(\mathrm{VI})$ oxides segregated in alumino-silicate rind.

- In the deep vadose sediment, surface secondary mineralization extended the level of groundwater

J. G. Catalano (Stanford University) presented the results of X-ray absorption spectroscopy (XAS) analyses of the uranium contamination in the 300 Area samples. The EXAFS spectra for the North Pond samples indicated that the uranium was at least partially coordinated by carbonate. Some of the spectra also suggested that a separate uranium precipitate, possibly a hydroxide phase, was also present.

\subsubsection{Sorption}

The dissolved concentrations of U(VI) beyond the very near field of the IDF likely will be controlled by adsorption processes in Hanford vadose zone and unconfined aquifer system. Because U(VI) exists primarily as strong aqueous anionic U(VI) carbonate complexes, which do not readily adsorb to the naturally negatively charged Hanford Site sediments at neutral-to-alkaline pH conditions, U(VI) is considered moderately to highly mobile in Hanford aqueous systems away from local sources of uranium contamination. An extensive review of published uranium adsorption studies is given in EPA (1999b). Uranium(VI) adsorbs onto a variety of minerals and related phases, including clays (Ames et al. 1982; Chisholm-Brause et al. 1994), oxides and silicates (Hsi and Langmuir 1985; Waite et al. 1994), and natural organic material (Borovec et al. 1979; Shanbhag and Choppin 1981; Read et al. 1993). Important environmental parameters affecting uranium adsorption include redox conditions, $\mathrm{pH}$, and concentrations of complexing ligands such as dissolved carbonate, ionic strength, and mineralogy.

As with the adsorption of most dissolved metals, $\mathrm{pH}$ has a significant effect on $\mathrm{U}(\mathrm{VI})$ adsorption because $\mathrm{pH}$ strongly influences $\mathrm{U}(\mathrm{VI})$ aqueous speciation and the number of exchange sites on variablecharged surfaces of solids such as iron oxides, aluminum oxides, and natural organic matter. Uranium sorption to iron oxides and smectite clay has been shown to be extensive in the absence of $\mathrm{CO}_{3}{ }^{2-}\left(\mathrm{Kent}^{2}\right.$ et al. 1988; Hsi and Langmuir 1985; Ames et al. 1982). In the presence of $\mathrm{CO}_{3}{ }^{2-}$ and organic complexants, U(VI) sorption was shown to be substantially reduced or severely inhibited (Hsi and Langmuir 1985; Kent et al. 1988; Ames et al. 1982). Depending on the adsorbent, the measured adsorption of U(VI) by soils and single-mineral phases in carbonate-containing aqueous solutions is low at $\mathrm{pH}$ values less than 3 , increases rapidly with increasing $\mathrm{pH}$ from 3 to 5 , reaches a maximum in adsorption in the $\mathrm{pH}$ range 
from 5 to 7 to 8 , and then decreases with increasing $\mathrm{pH}$ at values greater than 7 to 8 , depending on adsorbent (see Figure J.4 in EPA [1999b] and references cited therein). The observed increase in U(VI) adsorption onto sediments from acidic to near-neutral $\mathrm{pH}$ values is due to the dominant $\mathrm{U}(\mathrm{VI})$ aqueous species being cationic and neutral over this $\mathrm{pH}$ range. The subsequent decrease in U(VI) adsorption with increasing $\mathrm{pH}$ values results from the dominant $\mathrm{U}(\mathrm{VI})$ aqueous species being anionic $\mathrm{U}(\mathrm{VI})$ carbonate complexes. In the absence of dissolved carbonate, uranium sorption to iron oxide and clay minerals has been shown to be extensive and remains at a maximum at $\mathrm{pH}$ values near and above neutral (Kent et al. 1988; Hsi and Langmuir 1985; Ames et al. 1982). In the presence of carbonate and organic complexants, $\mathrm{U}(\mathrm{VI})$ adsorption has been shown to be substantially reduced or inhibited at neutral to basic $\mathrm{pH}$ values. Even differences in partial pressures of $\mathrm{CO}_{2}$ have a major effect on uranium adsorption at neutral $\mathrm{pH}$ conditions. Waite et al. (1994), for example, showed that the percent of U(VI) adsorbed onto ferrihydrite decreases from approximately 97 to $38 \%$ when $\mathrm{CO}_{2}$ is increased from ambient $(0.03 \%)$ to elevated $(1 \%)$ partial pressures.

Other secondary factors may affect the mobility of uranium as well. For example, in low ionicstrength solutions, the uranyl ion concentrations probably will be affected, in part, by cation-exchange adsorption process. Uranium(VI) will adsorb onto clays, organics, and oxides, and this will limit its mobility. As the ionic strength of an oxidized solution increases, other ions, notably $\mathrm{Ca}^{2+}, \mathrm{Mg}^{2+}$, and $\mathrm{K}^{+}$, will displace the uranyl ion, forcing it into solution. Not only will other cations out-compete the U(VI) for exchange sites, but carbonate ions will form strong soluble complexes with the uranyl ion, further lowering its affinity for positively charged solids while increasing the total amount of uranium in solution (Yeh and Tripathi 1991).

Some of the sorption processes in which U(VI) participates are not completely reversible. Sorption onto iron and manganese oxides can be a major process for extraction of uranium from solution. These oxide phases act as a short-term, irreversible sink for uranium in soils. Uranium bound in these phases is not generally in isotopic equilibrium with dissolved uranium in the same system, suggesting that the reaction mediating the transfer of the metal between the two phases is slow.

Solid-phase organics are another possible sink for uranyl ions in soils and to smaller extents in sediments. The mechanisms for uranium sequestration onto organic-rich sediments are numerous and complex. One mechanism may involve sorption of the uranyl cation onto exchange sites such as carboxylic acid groups. These groups can coordinate with the uranyl ion, displacing water of hydration and forming stable complexes. A process like this probably accounts for a significant fraction of the organically bound uranium in soils and, perhaps, in sediments. Alternatively, sedimentary organics may reduce dissolved U(VI) species to U(IV) species. These reduced species are generally low in solubility and may remain associated with the organic phase after precipitation as a reduced oxide. Little seems to be known about the nature of organic uranium associations in soils or sediments on a molecular level, although several different types of interactions may be taking place. The amount of naturally occurring organic substances such as fulvic and humic acids is quite low in the subsurface of the Hanford Site. There is a possibility that the contaminant plume leaving the near field may contain some organic substances (sulfur polymer cement contains $5 \%$ organic binder, and asphalt also may be used in covers). Both of these engineered materials possess some of chemical properties of the organic substances found in natural systems. 
Rancon (1973) studied the adsorption of uranium using four soils and three pure-phase minerals. Quartz was characterized as inert $\left(\mathrm{K}_{\mathrm{d}}=0 \mathrm{~mL} / \mathrm{g}\right)$, calcite was a poor uranium adsorber $\left(\mathrm{K}_{\mathrm{d}}=7 \mathrm{~mL} / \mathrm{g}\right)$, and illite and other $2: 1$ clays $\left(\mathrm{K}_{\mathrm{d}}=139\right.$ to $\left.270 \mathrm{~mL} / \mathrm{g}\right)$ were the best adsorbers of uranium from solution. Acidic, organic-rich soils showed higher uranium sorption $\left(\mathrm{K}_{\mathrm{d}}=33 \mathrm{~mL} / \mathrm{g}\right)$ than soils containing carbonate minerals $\left(\mathrm{K}_{\mathrm{d}}=16 \mathrm{~mL} / \mathrm{g}\right)$. The importance of $\mathrm{U}(\mathrm{VI})$ sorption to inorganic solid phases such as clays and iron oxides may be minor in many natural environments because of the limited quantity of these materials, the presence of particulate or dissolved organic matter, and/or dissolved carbonate.

Formation of complexes between U(VI) and organic ligands such as humic and fulvic particulates has been studied frequently because of interest in ore-forming environments. At ambient temperatures $\left(\sim 25^{\circ} \mathrm{C}\right)$, uranium is adsorbed to humic substances through rapid ion-exchange and complexation processes with carboxylic and other acidic functional groups (Idiz et al. 1986; Boggs et al. 1985; Shanbhag and Choppin 1981; Nash et al. 1981; Borovec et al. 1979). The adsorption often is followed by reduction to the U(IV) species followed by precipitation of $\mathrm{UO}_{2}$ (Andreyev and Chumachenko 1964). In studies with lignite, the uranyl species formed a stable complex with the lignite without subsequent reduction; reduction only occurred at elevated temperatures (Nakashima et al. 1984). Organic matter does have the capacity to act as a reductant, most notably because of the presence of quinone, sulfone, and reduced metal porphyrin (tetrapyroles) moieties (Macalady et al. 1986).

Gamerdinger et al. (1998) conducted a series of experiments using an unsaturated flow apparatus $\left(\mathrm{UFA}^{\mathrm{TM}}\right)$ to measure the adsorption and mobility of U(VI) under partial moisture saturation conditions that are relevant to waste burial sites and vadose-zone far-field conditions at the Hanford Site. The sediments used for these measurements included a medium-coarse sand, Touchet bed fine sand, and Warden silt loam. The experiments were conducted with uncontaminated groundwater with $\mathrm{pH} 8.4$ from the Hanford Site. For the conditions considered for their experiments, Gamerdinger et al. (1998) determined that $\mathrm{U}(\mathrm{VI}) \mathrm{K}_{\mathrm{d}}$ values decreased with decreasing moisture saturation irrespective of sediment texture. The $\mathrm{K}_{\mathrm{d}}$ values determined by Gamerdinger et al. (1998) for the medium-coarse sand decreased from 0.48 to $0.16 \mathrm{~mL} / \mathrm{g}$ at moisture saturations from 30 to $12 \%$, respectively. For the fine sand, the U(VI) $\mathrm{K}_{\mathrm{d}}$ values were 1.42 and $0.39 \mathrm{~mL} / \mathrm{g}$ at moisture saturations of 66 and $22 \%$, respectively. For the silt loam, the U(VI) $\mathrm{K}_{\mathrm{d}}$ values were 4.05 and $1.81 \mathrm{~mL} / \mathrm{g}$ at moisture saturations of 83 and $41 \%$, respectively. There is a concern that the reduction in $\mathrm{K}_{\mathrm{d}}$ values may partly be an artifact of the short residence times in the UFA as opposed to a physicochemical process, such as sorption sites that are not exposed to water, and thus adsorbates, such as $\mathrm{U}(\mathrm{VI})$, in the unsaturated sediments. Until we are fully convinced that $\mathrm{K}_{\mathrm{d}}$ values are, in fact, lower for unsaturated moisture conditions based on more fully understood physicochemical mechanisms, we will continue to use $\mathrm{K}_{\mathrm{d}}$ values based on traditional batch and column tests performed under saturated conditions.

The 300 Area study by Serne et al. (2002a) (see Section 3.7.2) also included laboratory experiments to measure the adsorption characteristics of uranium in near-surface sediment samples collected from the 300 Area. Serne et al. (2002a) completed adsorption experiments to investigate the effects of dissolved uranium concentrations, $\mathrm{pH}$, and dissolved inorganic carbon (as carbonate/bicarbonate) concentrations on uranium adsorption onto uncontaminated sediment. Uranium adsorption $\mathrm{K}_{\mathrm{d}}$ values ranged from $0 \mathrm{~mL} / \mathrm{g}$ to more than $100 \mathrm{~mL} / \mathrm{g}$ depending on which solution parameter was being adjusted. Results of the experiments showed that total concentration of dissolved inorganic carbon had the largest affect on uranium adsorption onto uncontaminated 300 Area sediment. Solution $\mathrm{pH}$ also was shown to be important in laboratory tests. The mineral content of the natural sediment buffers $\mathrm{pH}$ to a nearly constant value, which 
therefore minimizes the overall effect of $\mathrm{pH}$ changes in the 300 Area sediments. Results from the batch adsorption tests by Serne et al. (2002a) also indicate that uranium sorption onto the background sediment is linear up to uranium concentrations of $3 \mathrm{mg} / \mathrm{L}$ (holding all other parameters constant), which is well above the values found in the upper unconfined aquifer. Thus, the linear isotherm assumption holds for uranium in the 300 Area sediment-pore water environment.

Barnett et al. (2002) recently used batch adsorption experiments and a surface complexation model to study the pH-dependent adsorption of U(VI) on sediment and soil samples from Hanford, Oak Ridge, and Savannah River. The sediment sample from the Hanford Site was from the Upper Ringold Formation, obtained from the White Bluffs area above the Columbia River. Barnett et al. (2002) used the surface complexation model developed for U(VI) adsorption onto ferrihydrite by Waite et al. (1994) to predict $\mathrm{U}(\mathrm{VI})$ adsorption on these sediments as a function of $\mathrm{pH}$. Application of this model necessitated that Barnett et al. (2002) assume that all of the dithionite-citrate-bicarbonate extractable iron oxides in these sediment samples was present as ferrihydrite. The modeling results of Barnett et al. (2002) qualitatively predicted the main characteristics of the $\mathrm{pH}$-dependent adsorption of U(VI) on these sediments in carbonate-containing systems. Barnett et al. (2002) suggested that this modeling approach could be used to assess the relative mobility of U(VI) in geochemical systems by indicating whether U(VI) was weakly or strongly adsorbed onto the geologic materials. Surface complexation models likely will receive increased use in the future in developing a better understanding of surface reactions and site conceptual models and in estimating limiting $K_{d}$ values for the adsorption of metals, especially for uranium, in the vadose zone and other geochemical environments.

As discussed in Section 3.7.2, investigations are currently underway to study uranium-contaminated sediments from the 300 Area uranium plume in 300-FF-5 and develop reactive transport modeling approaches to assist with evaluation of alternate remediation approaches. J. A. Davis and coworkers from the U.S. Geological Survey presented the results of laboratory studies and progress toward developing a generalized surface complexation model (SCM) based on the approach described in Davis and Curtis (2003) and Curtis et al. (2004) to model uranium sorption in sediment samples from the 300 Area uranium plume. Based on the studies completed to date, Davis and coworkers concluded (taken essentially verbatim from their presentation):

- $\mathrm{U}(\mathrm{VI})$ desorption is very sensitive to alkalinity changes.

- Contaminated sediment samples contain significant fractions of both adsorbed (labile) and "coprecipitated" U(VI).

- Coprecipitated U(VI) can be dissolved by hydroxylamine hydrochloride extractions.

- Semi-empirical generalized SCM describes the partitioning of the labile U(VI) fraction reasonably well, but likely needs further testing with other samples.

Cantrell et al. (2003) compiled the $\mathrm{K}_{\mathrm{d}}$ values measured with Hanford sediment for radionuclides and contaminants of environmental concern to the vadose zone and groundwater at Hanford. Table 16 in Cantrell et al. (2003) lists the compiled $\mathrm{K}_{d}$ values determined for U(VI) using Hanford sediment. The compiled data indicate that $\mathrm{U}(\mathrm{VI})$ adsorption is low to moderate with $\mathrm{K}_{\mathrm{d}}$ values ranging from approximately 0.2 to 4 for natural Hanford groundwater conditions. Serne et al. (1993) reported 
$\mathrm{K}_{\mathrm{d}}$ values that were much higher, but Cantrell et al. considered some of these values suspect and noted that adsorption should be lower for U(VI) adsorption measured in acid process waste by Serne et al. (1993) due to the lower equilibrium $\mathrm{pH}$ values reached in these experiments. The $\mathrm{K}_{\mathrm{d}}$ value for U(VI) from the acid process waste was much higher than observed in any other studies (Serne et al. 1993). As indicated by Cantrell et al. (2003), the maximum in the adsorption of U(VI) on natural sediment in groundwater systems occurs in the $\mathrm{pH}$ range from approximately 6 to 8 , with adsorption decreasing at lower $\mathrm{pH}$ values due to protonation of the adsorption sites and the dominance of cationic aqueous U(VI) species at lower $\mathrm{pH}$ conditions (Payne and Waite 1991; Davis 2001). As discussed previously, the adsorption of $\mathrm{U}(\mathrm{VI})$ on sediment also decreases with increasing $\mathrm{pH}$ values at $\mathrm{pH}$ values greater than about 7 due to the formation of anionic aqueous U(VI) carbonate species and the deprotonation of the surface sites. Cantrell et al. (2003) noted that the high $\mathrm{K}_{\mathrm{d}}$ values reported for U(VI) by Serne at al. (1993) were used in the geochemistry data package report for the 2001 ILAW PA, where Kaplan and Serne (2000) recommended a $\mathrm{K}_{\mathrm{d}}$ range for ${ }^{234 / 235 / 238} \mathrm{U}$ of 0.1 to $80 \mathrm{~mL} / \mathrm{g}$. Based on their more recent analysis, Cantrell et al. (2003) now conclude that a $\mathrm{K}_{\mathrm{d}}$ range of 0.2 to $4 \mathrm{~mL} / \mathrm{g}$ is more likely representative for $\mathrm{U}(\mathrm{VI})$ for geochemical conditions associated with the vadose zone and unconfined aquifer systems at the Hanford Site. The $\mathrm{K}_{\mathrm{d}}$ range listed for ${ }^{234 / 235 / 238} \mathrm{U}$ by Cantrell et al. will be used in the data package for the 2005 IDF PA. Of note is the fact that $\mathrm{K}_{\mathrm{d}}$ values for $\mathrm{U}(\mathrm{VI})$ in vadose zone sediments affected by waste leachate may be lower than the range 0.2 to $4 \mathrm{~mL} / \mathrm{g}$ that Cantrell et al. (2003) recommended for background Hanford geochemical conditions. More discussion is found in Section 6.0.

\subsection{Other Studies of Potential Interest}

The DOE and its contractors at the Hanford Site have funded numerous studies pertaining to the geochemical processes affecting the sorption and migration of contaminants in the sediments and groundwater at Hanford. Many of these studies are cited in the geochemistry summaries provided above, which focus on geochemical processes and studies pertaining primarily to conditions and contaminants of interest with respect to the IDF.

During the past few years, the results of several contaminant geochemistry studies unrelated to the IDF also have been published. These studies were typically supported by DOE through its Environmental Management Science Program (EMSP), Hanford Science and Technology (S\&T) Program within the Groundwater/ Vadose Zone Integration Protection Project, and Hanford Site contractors, such as CH2M HILL. These studies may be of interest to the reader and may have potential relevance to the performance assessment calculations in ways unforeseen at this time. The majority of these studies focus on understanding the geochemical interactions when highly caustic and highly saline Hanford tank waste solutions contact vadose sediments and the impact of these reactions on contaminant mobility. These studies are simply listed below without summary or critique, and include the following experimental and modeling studies:

- Identifying sources of subsurface contamination from isotopic measurements - Christensen et al. (2004) and Maher et al. (2003)

- Biochemical processes at groundwater-surface water boundaries - Moser et al. (2003)

- Geomicrobiology of waste-contaminated vadose sediments - Fredrickson et al. (2004) 
- Reactions of simulated Hanford tank solutions (i.e., highly alkaline $\mathrm{NaNO}_{3}$ solutions) with vadose zone sediments - Bickmore et al. (2001), Flury et al. (2004), Nyman et al. (2000), Qafoku et al. (2003a, c, 2004), Um et al., ${ }^{\text {(a) }}$ Wan et al. (2004a, b), Zhao et al. (2004)

- Radionuclide sorption behavior and sediment reactions associated with interaction of simulated Hanford tank solutions with vadose zone sediments

- Cesium - Chorover et al. (2003), Flury et al. (2002, 2004), Liu et al. (2003a, b, 2004), McKinley et al. (2001, 2004), Steefel et al. (2003), Zachara et al. (2002b), Zhuang et al. (2003)

- Chromium(VI) - Qafoku et al. (2003b), Zachara et al. (2004)

- Iodine(-I) - Um et al. ${ }^{(a)}$

- Selenium(VI) - Um et al. ${ }^{(a)}$

- Strontium - Chorover et al. (2003), Um et al. ${ }^{(a)}$

- Technetium(VII) - Um et al. ${ }^{(\text {a) }}$

(a) Um W, SD Samson, RJ Serne, SB Yabusaki, and KL Nagy. "The effects of secondary mineral precipitates on radionuclide transport and sequestration at the Hanford Site." Submitted to Environmental Science and Technology. 


\subsection{Approach}

The geochemical data for both the near and far fields are organized into nine lookup tables, one for each environmental zone that was chosen to represent the pathway for contaminant release from the IDF to the Columbia River. It is important to understand that the current disposal baseline for the IDF is two large football field-sized disposal cells into which various solid wastes (ILAW glass, various solid and solidified low-level radioactive wastes, various solid mixed wastes, and spent glass melters) will be placed. The following is a brief description of the IDF facility taken from Puigh (2004). The interested reader is referred to Puigh (2004) for more information.

The proposed IDF will be located on the ILAW site southwest of the 200 East Area's PUREX facility on the Hanford Site. The facility's trench design is an expandable lined landfill approximately $410 \mathrm{~m}$ wide and up to $13.2 \mathrm{~m}$ deep. The length of the trench, oriented in the north-south direction, will be divided into two distinct cells, each of which can be expanded to accommodate waste receipts during its operational life. The design includes sloped (3:1) side walls for the trench. The landfill will be divided lengthwise (north-south orientation) into two distinct cells. The easternmost, Cell 2, will contain the lowlevel radioactive waste (ILAW glass from the WTP). Cell 1 will contain a mixture of waste types (ILAW glass, supplemental technology vitrified wastes [bulk vitrified wastes], "traditional" solid wastes [lowlevel and mixed low-level], secondary wastes from vitrification off-gas scrubbing systems and spent melters). Each cell is designed to meet the Resource Conservation and Recovery Act (RCRA) liner requirements with leachate collection and leak detection systems. The leachate collection system includes two RCRA compliant liners [including high-density polyethylene (HDPE) geomembrane and admix drainage layers], each associated with sumps, pumps, and leak-detection equipment. The IDF trench design includes backfilled native sandy soil around and on top of the waste containers in the facility. The closure plan is to cover the landfill with a modified RCRA Subtitle C barrier. The barrier is designed to prevent intrusion and to provide hydrologic protection and containment for a performance period of 500 years. The barrier overhang will extend beyond the edge of the IDF trench. The surface barrier has not yet been designed for the IDF but is expected to include various layers of coarse and fine sediments, asphalt, asphaltic concrete, and a surface topsoil in which mixed perennial grasses, shrubs, and sagebrush will be planted. Beneath the surface barrier, a sand-gravel capillary break is assumed that will divert away from the trench any moisture that may come through the surface barrier. The various barriers are intended to minimize the amount of water that enters the trench.

The physical, chemical, and radiological properties of the waste at the time of disposal have not been completely determined. The WTP ILAW glass waste form is expected to be contained in right circular, steel cylindrical containers (1.22 $\mathrm{m}$ diameter by $2.29 \mathrm{~m}$ tall). The spent melters will be overpacked, likely with carbon steel that provides the necessary shielding, contamination control, and structural rigidity to allow direct burial of the spent melters as MLLW. For this risk assessment, it is assumed that a 1-inchthick steel rectangular overpack is used for the LAW melters, and both the LAW and HLW melters are assumed to be grouted into their respective overpacks. The waste package designs that will be used to dispose of LLW and MLLW solid wastes in the IDF are not known, but likely will include 55 gallon drums and steel waste burial boxes. For the 2005 IDF performance assessment, we have assumed that all the WTP supplemental technology waste is processed by the bulk vitrification (BV) process. The BV waste package geometry has not been finalized. The preliminary waste package design assumes a rectangular box having dimensions of $2.4 \mathrm{~m}(\mathrm{H}) \times 7.5 \mathrm{~m}(\mathrm{~L})$ x $3.0 \mathrm{~m}(\mathrm{~W})\left(8^{\prime} \times 24^{\prime}\right.$ x 10'). The loading of 
waste into each IDF cell is assumed to be in "close pack array" layers called lifts. The planning lift thickness corresponds to the waste stack height (typically $2.3 \mathrm{~m}$ ) and cover soil layer (typically $1 \mathrm{~m}$ ). The current planning is to locate spent melters on the bottom lift (Lift 1).

Our assumption is that Cell 2, containing ILAW glass waste, will generate a leachate whose chemistry is dominated by the ILAW waste glass. The chemical composition of the ILAW glass leachate was determined for the 2001 ILAW PA and is described in more detail in Section 6. The other cell, Cell 1, with all the waste types, could generate several types of leachates that at this time have not been investigated or measured. For the 2005 IDF PA, we assume three scenarios are possible. The first is that leachate from Cell 1 is also dominated by ILAW glass dissolution and that subsequent interactions with the vadose zone are the same as described for Cell 2. The second scenario is that the leachate from Cell 1 is dominated by cement dissolution in the near-field vadose zone sediments below the IDF facility. The third scenario is that Cell 1, and for that matter Cell 2 also, contains no significant quantities of dissolved species, and thus its major constituent chemistry is assumed to be that of native vadose zone pore water, which is similar to natural Hanford groundwater. The features of all the conceptual geochemical zones are presented in Tables 4.1 through 4.3. The tables assume that the entire vadose zone is either completely impacted by waste leachate or is not impacted at all. Should the vadose zone pore waters outside of the IDF facility itself be partially waste-leachate impacted, then the appropriate Zones $2 \mathrm{a}, 2 \mathrm{~b}$, and $3 \mathrm{a}$ can be added as appropriate to cover specific depth ranges. The appropriate $\mathrm{K}_{\mathrm{d}}$ and empirical solubility concentration values for each zone are found in Section 5 and designated in Tables 4.1 through 4.3.

Table 4.1. Conceptual Features of the Geochemical Zones for the IDF Cell 1 that Contains all Types of IDF Wastes and Has Leachate Dominated by Cement

\begin{tabular}{|c|c|c|c|}
\hline $\begin{array}{c}\text { Zone } \\
\text { (Data Table) }\end{array}$ & Solid Phases & Aqueous Phase & $\begin{array}{l}\text { Geochemical } \\
\text { Parameters Used in } \\
\text { Zone }\end{array}$ \\
\hline $\begin{array}{l}\text { Zone } 1 \mathrm{~b}-\text { Cementitious } \\
\text { Secondary Wastes and } \\
\text { Near Field (Tables } 5.3 \\
\text { and 5.4) }\end{array}$ & $\begin{array}{l}\text { Three assemblages of } \\
\text { cementitious minerals will } \\
\text { exist, based on cement age; } \\
\text { fresh cement with } \mathrm{pH}=12.5, \\
\text { moderately aged cement with } \\
\mathrm{pH} \sim 10.5 \text {, and completely } \\
\text { aged cement with } \mathrm{pH} \sim 8.5\end{array}$ & $\begin{array}{l}\text { Three types of concrete leachate } \\
\text { chemistries controlled by different aged } \\
\text { solid phases: young concrete leachate } \\
\text { pH } 12.5 \text {, then pH } 10.5 \text {, final pH } 8.5 \text {; } \\
\text { generally high in ionic strength and high } \\
\text { radionuclide concentration }\end{array}$ & $\begin{array}{l}\mathrm{K}_{\mathrm{d}} \text {, empirical } \\
\text { solubility } \\
\text { concentration limits }\end{array}$ \\
\hline $\begin{array}{l}\text { Zone } 2 \mathrm{a}-\text { Chemically } \\
\text { Impacted Far Field in } \\
\text { Sand Sequence (Table } \\
5.5 \text { ) }\end{array}$ & $\begin{array}{l}\text { Sand-dominated sequence, } \\
\text { slightly altered because of } \\
\text { contact with moderately } \\
\text { caustic aqueous phase }\end{array}$ & $\begin{array}{l}\mathrm{pH} 8 \text { (background) to } 11 \text {, ionic strength } \\
0.01 \text { (background) to } 0.1 \text {, low } \\
\text { radionuclide concentration }\end{array}$ & $\mathrm{K}_{\mathrm{d}}$ \\
\hline $\begin{array}{l}\text { Zone } 3 \mathrm{a}-\text { Chemically } \\
\text { Impacted Far Field in } \\
\text { Gravel Sequence } \\
\text { (Table 5.7) }\end{array}$ & $\begin{array}{l}\text { Same as zone } 2 \mathrm{a} \text {, except in } \\
\text { gravel-dominated sequence }\end{array}$ & $\begin{array}{l}\text { Same as zone } 2 \mathrm{a} \text {, except in gravel- } \\
\text { dominated sequence }\end{array}$ & $\mathrm{K}_{\mathrm{dgc}}$ \\
\hline $\begin{array}{l}\text { Zone } 4-\text { Far Field in } \\
\text { Gravel Sequence } \\
\text { (Table 5.8) }\end{array}$ & $\begin{array}{l}\text { Unaltered Hanford Site gravel } \\
\text { sequence ( } 90 \% \text { gravel, } 10 \% \\
<2 \mathrm{~mm})\end{array}$ & $\begin{array}{l}\text { Unaltered Hanford Site groundwater, } \\
\text { except for trace levels of radionuclides }\end{array}$ & $\mathrm{K}_{\mathrm{dgc}}$ \\
\hline $\begin{array}{l}\text { Zone } 5 \text { - Unconfined } \\
\text { Far Field Aquifer } \\
\text { Conditions } \\
\text { (Table 5.9) }\end{array}$ & $\begin{array}{l}\text { Sand-dominated sequence, } \\
\text { not altered by composition of } \\
\text { leachate from wastes }\end{array}$ & $\begin{array}{l}\mathrm{pH} \sim 8 \text { (background), ionic strength } 0.01 \\
\text { (background) to } 0.1 \text {, except for possible } \\
\text { trace levels of radionuclide } \\
\text { concentrations }\end{array}$ & $\mathrm{K}_{\mathrm{d}}$ \\
\hline
\end{tabular}


Table 4.2. Conceptual Features of the Geochemical Zones for the IDF Cell 1 that Contains all Types of IDF Wastes and Has Leachate Outside IDF Dominated by Natural Recharge Water. (Leachate from waste does not contain significant concentrations of macro constituents. If there is some impact from the leachate, Zones $2 \mathrm{a}, 2 \mathrm{~b}$, and $3 \mathrm{a}$ should be added as appropriate.)

\begin{tabular}{|c|c|c|c|}
\hline $\begin{array}{c}\text { Zone } \\
\text { (Data Table) }\end{array}$ & Solid Phases & Aqueous Phase & $\begin{array}{l}\text { Geochemical } \\
\text { Parameters Used in } \\
\text { Zone }\end{array}$ \\
\hline $\begin{array}{l}\text { Zone } 1 \mathrm{a}-\text { Vitrified } \\
\text { Wastes and Near Field } \\
\text { (Tables } 5.1 \text { and 5.2) }\end{array}$ & $\begin{array}{l}\text { Glass, secondary phases } \\
\text { formed from glass } \\
\text { degradation, and backfill and } \\
\text { engineered barrier materials }\end{array}$ & $\begin{array}{l}\text { Glass leachate: high } \mathrm{pH} \text {, high ionic } \\
\text { strength, high radionuclide } \\
\text { concentrations }\end{array}$ & $\begin{array}{l}\mathrm{K}_{\mathrm{d}} \text {, empirical } \\
\text { solubility } \\
\text { concentration limits }\end{array}$ \\
\hline $\begin{array}{l}\text { Zone } 1 \mathrm{~b}-\text { Cementitious } \\
\text { Secondary Wastes and } \\
\text { Near Field (Tables } 5.3 \\
\text { and 5.4) }\end{array}$ & $\begin{array}{l}\text { Three assemblages of } \\
\text { cementitious minerals will } \\
\text { exist, based on cement age; } \\
\text { fresh cement with } \mathrm{pH}=12.5, \\
\text { moderately aged cement with } \\
\mathrm{pH} \sim 10.5, \text { and completely } \\
\text { aged cement with } \mathrm{pH} \sim 8.5\end{array}$ & $\begin{array}{l}\text { Three types of concrete leachate } \\
\text { chemistries controlled by different aged } \\
\text { solid phases: young concrete leachate } \\
\text { pH } 12.5 \text {, then pH } 10.5 \text {, final } \mathrm{pH} 8.5 \text {; } \\
\text { generally high in ionic strength and high } \\
\text { radionuclide concentration }\end{array}$ & $\begin{array}{l}\mathrm{K}_{\mathrm{d}} \text {, empirical } \\
\text { solubility } \\
\text { concentration limits }\end{array}$ \\
\hline $\begin{array}{l}\text { Zone } 2 b-\text { Far Field in } \\
\text { Sand Sequence with } \\
\text { Natural Recharge (no } \\
\text { impact from wastes) } \\
\text { (Table 5.6) }\end{array}$ & $\begin{array}{l}\text { Sand-dominated sequence, } \\
\text { not altered because leachate } \\
\text { from solid wastes contains } \\
\text { insignificant concentrations of } \\
\text { leached material }\end{array}$ & $\begin{array}{l}\mathrm{pH} \sim 8 \text { (background), ionic strength } 0.01 \\
\text { (background) to } 0.1 \text {, low radionuclide } \\
\text { concentration }\end{array}$ & $\mathrm{K}_{\mathrm{d}}$ \\
\hline $\begin{array}{l}\text { Zone } 3 \mathrm{~b}-\text { Far Field in } \\
\text { Gravel Sequence } \\
\text { (Table 5.8) }\end{array}$ & $\begin{array}{l}\text { Same as zone } 2 \mathrm{~b} \text {, except in } \\
\text { gravel-dominated sequence }\end{array}$ & $\begin{array}{l}\text { Same as zone } 2 b \text {, except in gravel- } \\
\text { dominated sequence }\end{array}$ & $\mathrm{K}_{\mathrm{dgc}}$ \\
\hline $\begin{array}{l}\text { Zone } 4-\text { Far Field in } \\
\text { Gravel Sequence } \\
\text { (Table 5.8) }\end{array}$ & $\begin{array}{l}\text { Unaltered Hanford Site gravel } \\
\text { sequence }(90 \% \text { gravel, } 10 \% \\
<2 \mathrm{~mm})\end{array}$ & $\begin{array}{l}\text { Unaltered Hanford Site groundwater, } \\
\text { except for trace levels of radionuclides }\end{array}$ & $\mathrm{K}_{\mathrm{dgc}}$ \\
\hline $\begin{array}{l}\text { Zone } 5 \text { - Unconfined } \\
\text { Far Field Aquifer } \\
\text { Conditions (Table 5.9) }\end{array}$ & $\begin{array}{l}\text { Sand-dominated sequence, } \\
\text { not altered by composition of } \\
\text { leachate from wastes }\end{array}$ & $\begin{array}{l}\mathrm{pH} \sim 8 \text { (background), ionic strength } 0.01 \\
\text { (background) to } 0.1 \text {, except for possible } \\
\text { trace levels of radionuclide } \\
\text { concentrations }\end{array}$ & $\mathrm{K}_{\mathrm{d}}$ \\
\hline
\end{tabular}

Schematic representations of the various zones for disposal Cell 1, which contains all the waste forms, are presented in Figures 4.1 and 4.2 for various scenarios. Figure 4.3 is a third schematic representation for zones associated with the disposal cell that contains only ILAW glass or for the cell with mixed waste types that has leachate dominated by glass.

Each look-up table contains "empirical” $\mathrm{K}_{\mathrm{d}}$ and/or solubility concentration limit values. For each contaminant in each environmental zone, a most-probable estimate, a reasonable lower-bounding estimate, and a likely range of estimates are provided for the $\mathrm{K}_{\mathrm{d}}$ values. The distribution for all contaminant-specific $\mathrm{K}_{\mathrm{d}}$ parameters and empirical solubility concentration limits is assumed to be normally distributed about the most probable value for stochastic modeling. For each data entry, comments and references are provided to support the values.

One class of reactions that is not accounted for in the look-up tables is complexation of metal-like radionuclides with organic ligands that are formed when cellulosic (e.g., wood, paper, and cardboard) and other organic wastes (e.g., clothing, plastics, and rubber) degrade. These types of materials were not present in the past ILAW disposal facility. It is also not clear at this point whether large enough masses 
Table 4.3. Conceptual Features of the Geochemical Zones for Cell 2 that Contains ILAW Glass Only or Cell 1 that has Leachate Dominated by Glass Throughout Vadose Zone. (If the vadose zone is not impacted by glass leachate, Zones $2 \mathrm{a}$ and $3 \mathrm{a}$ are replaced by Zones $2 \mathrm{~b}$ and $3 \mathrm{~b}$.)

\begin{tabular}{|c|c|c|c|}
\hline $\begin{array}{c}\text { Zone } \\
\text { (Data Table) }\end{array}$ & Solid Phases & Aqueous Phase & $\begin{array}{l}\text { Geochemical } \\
\text { Parameters Used in } \\
\text { Zone }\end{array}$ \\
\hline $\begin{array}{l}\text { Zone } 1 \mathrm{a}-\text { Vitrified } \\
\text { Wastes and Near Field } \\
\text { (Tables } 5.1 \text { and 5.2) }\end{array}$ & $\begin{array}{l}\text { Glass, secondary phases } \\
\text { formed from glass } \\
\text { degradation, and backfill and } \\
\text { engineered barrier materials }\end{array}$ & $\begin{array}{l}\text { Glass leachate: high } \mathrm{pH} \text {, high ionic } \\
\text { strength, high radionuclide } \\
\text { concentrations }\end{array}$ & $\begin{array}{l}\mathrm{K}_{\mathrm{d}} \text {, empirical } \\
\text { solubility } \\
\text { concentration limits }\end{array}$ \\
\hline $\begin{array}{l}\text { Zone } 2 \mathrm{a}-\text { Chemically } \\
\text { Impacted Far Field in } \\
\text { Sand Sequence } \\
\text { (Table 5.5) }\end{array}$ & $\begin{array}{l}\text { Sand-dominated sequence, } \\
\text { slightly altered because of } \\
\text { contact with moderately } \\
\text { caustic aqueous phase }\end{array}$ & $\begin{array}{l}\mathrm{pH} 8 \text { (background) to } 11 \text {, ionic } \\
\text { strength } 0.01 \text { (background) to } 0.1 \text {, low } \\
\text { radionuclide concentration }\end{array}$ & $\mathrm{K}_{\mathrm{d}}$ \\
\hline $\begin{array}{l}\text { Zone } 2 \mathrm{~b}-\text { Far Field in } \\
\text { Sand Sequence with } \\
\text { Natural Recharge (no } \\
\text { impact from wastes) } \\
\text { (Table 5.6) }\end{array}$ & $\begin{array}{l}\text { Sand-dominated sequence, } \\
\text { not altered because leachate } \\
\text { from solid wastes contains } \\
\text { insignificant concentrations of } \\
\text { leached material }\end{array}$ & $\begin{array}{l}\mathrm{pH} \sim 8 \text { (background), ionic strength } \\
0.01 \text { (background) to } 0.1 \text {, low } \\
\text { radionuclide concentration }\end{array}$ & $\mathrm{K}_{\mathrm{d}}$ \\
\hline $\begin{array}{l}\text { Zone } 3 \mathrm{a}-\text { Chemically } \\
\text { Impacted Far Field in } \\
\text { Gravel Sequence } \\
\text { (Table 5.7) }\end{array}$ & $\begin{array}{l}\text { Same as Zone } 2 \mathrm{a} \text {, except in } \\
\text { gravel-dominated sequence }\end{array}$ & $\begin{array}{l}\text { Same as zone } 2 a \text {, except in gravel- } \\
\text { dominated sequence }\end{array}$ & $\mathrm{K}_{\mathrm{dgc}}$ \\
\hline $\begin{array}{l}\text { Zone } 3 b-\text { Far Field in } \\
\text { Gravel Sequence } \\
\text { (Table 5.8) }\end{array}$ & $\begin{array}{l}\text { Same as zone } 2 b \text {, except in } \\
\text { gravel-dominated sequence }\end{array}$ & $\begin{array}{l}\text { Same as zone } 2 b \text {, except in gravel- } \\
\text { dominated sequence }\end{array}$ & $\mathrm{K}_{\mathrm{dgc}}$ \\
\hline $\begin{array}{l}\text { Zone } 4-\text { Far Field in } \\
\text { Gravel Sequence } \\
\text { (Table } 5.8 \text { ) }\end{array}$ & $\begin{array}{l}\text { Unaltered Hanford Site gravel } \\
\text { sequence }(90 \% \text { gravel, } 10 \% \\
<2 \mathrm{~mm})\end{array}$ & $\begin{array}{l}\text { Unaltered Hanford Site groundwater, } \\
\text { except for trace levels of radionuclides }\end{array}$ & $\mathrm{K}_{\mathrm{dgc}}$ \\
\hline $\begin{array}{l}\text { Zone } 5 \text { - Unconfined } \\
\text { Far Field Aquifer } \\
\text { Conditions (Table 5.9) }\end{array}$ & $\begin{array}{l}\text { Sand-dominated sequence, } \\
\text { not altered by composition of } \\
\text { leachate from wastes }\end{array}$ & $\begin{array}{l}\mathrm{pH} \sim 8 \text { (background), ionic strength } \\
0.01 \text { (background) to } 0.1 \text {, except for } \\
\text { possible trace levels of radionuclide } \\
\text { concentrations }\end{array}$ & $\mathrm{K}_{\mathrm{d}}$ \\
\hline
\end{tabular}

of such materials will be present in the LLW and MLLW solid wastes to be disposed in Cell 1 of the IDF facility to significantly affect the fate of contaminants that leach and interact with the subsurface at Hanford. Discussions with informed staff working on the IDF PA led to a fairly strong consensus that this potential "enhanced migration" issue has a very low probability of impacting IDF. However, for completeness, the available literature on the impacts of organic degradation products on nuclear waste constituents leached from buried wastes will be reviewed, critically analyzed, and discussed in the next geochemical data package cycle. For the 2005 IDF PA, no consideration of this organic ligand enhanced mobility issue has been taken.

Whenever possible, the estimates provided in these tables were based on Hanford Site-specific experiments. Values are included for measurements actually completed using sediment samples from IDF boreholes. For example, Kaplan et al. (1998c) measured radionuclide $\mathrm{K}_{\mathrm{d}}$ values using sediment from 299-E17-21. More recently, Um et al. (2004) completed a series of experiments to determine the linearity and reversibility of I' adsorption onto Hanford formation sediment from the ILAW borehole \#2 (well 299- 


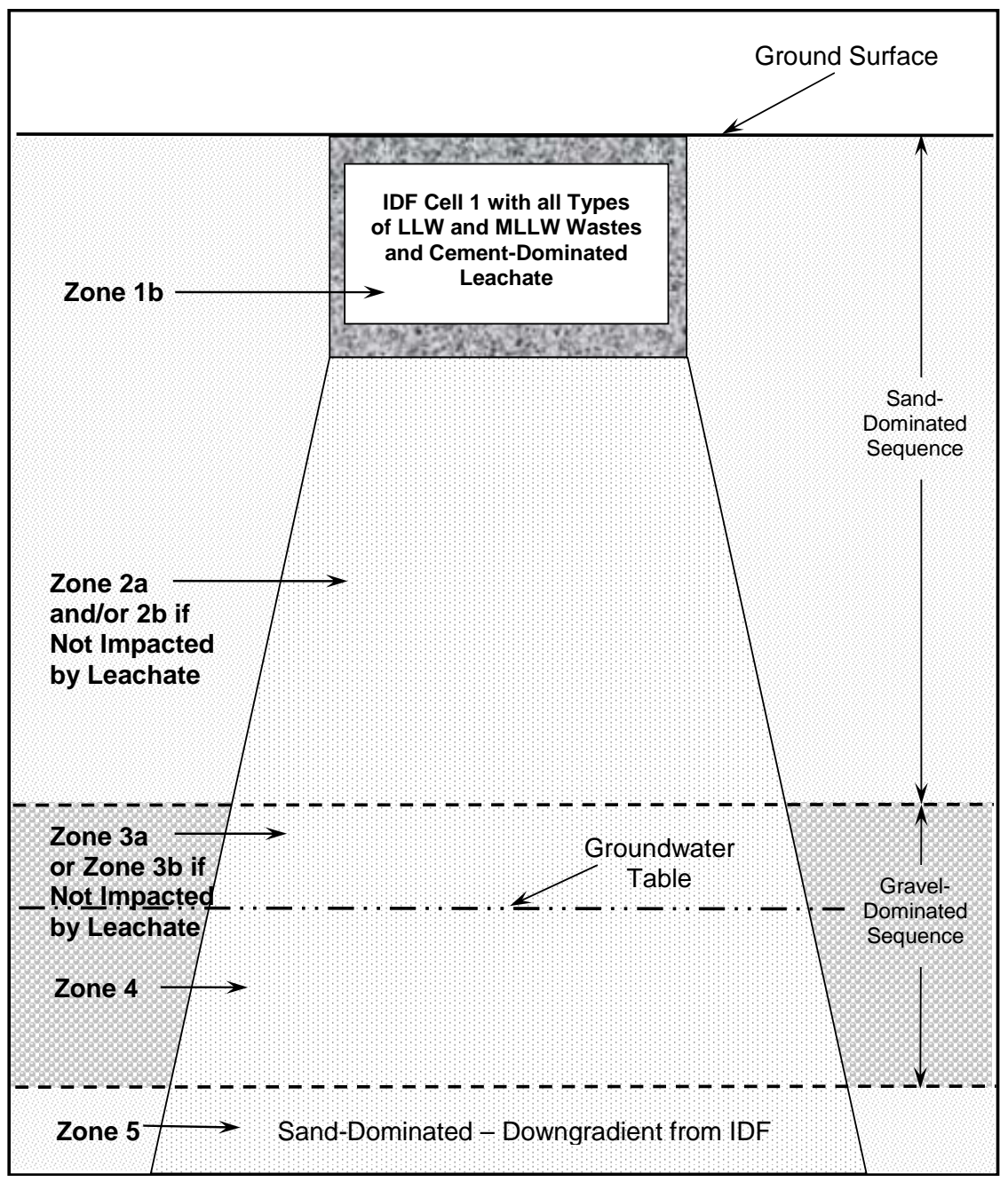

Figure 4.1. Schematic Representation (not to scale) of the Geochemical Zones for an IDF Cell (Cell 1) that Contains all Types of Wastes and Has a Pore Fluid Dominated by Cement Leachate in Portions of Vadose Zone

E24-21, borehole C3177). Um and Serne ${ }^{(a)}$ also completed a series of batch and column adsorption studies for ${ }^{99} \mathrm{Tc},{ }^{129} \mathrm{I},{ }^{75} \mathrm{Se}$ (as a surrogate for ${ }^{79} \mathrm{Se}$ ), and ${ }^{90} \mathrm{Sr}$ on sediments from ILAW borehole \#2 (C3177). Serne et al. (2002a) presents data on U(VI) $K_{d}$ values for a Hanford formation coarse-grained sediment from the 300 Area that is similar in texture, mineralogy, and other geochemical parameters to Hanford formation sediments obtained at the IDF site. Of particular note is the fact that the study by Serne et al. (2002a) used coarse-grained sediments that included the natural gravel content $(1.80 \mathrm{wt} \%)$ and thus no gravel correction factors would be necessary excepting for zones within the IDF sediments that contain substantially larger percentages of gravel.

Generic literature or offsite data were used when site-specific data were not available. Careful selection of generic literature $\mathrm{K}_{\mathrm{d}}$ values was required to ensure that the experimental conditions used to

(a) Um W and RJ Serne. 2004. "Sorption and Transport Behavior of Radionuclides in the Proposed Low-Level Radioactive Waste Disposal Facility at the Hanford Site, Washington." Submitted to Radiochimica Acta. 


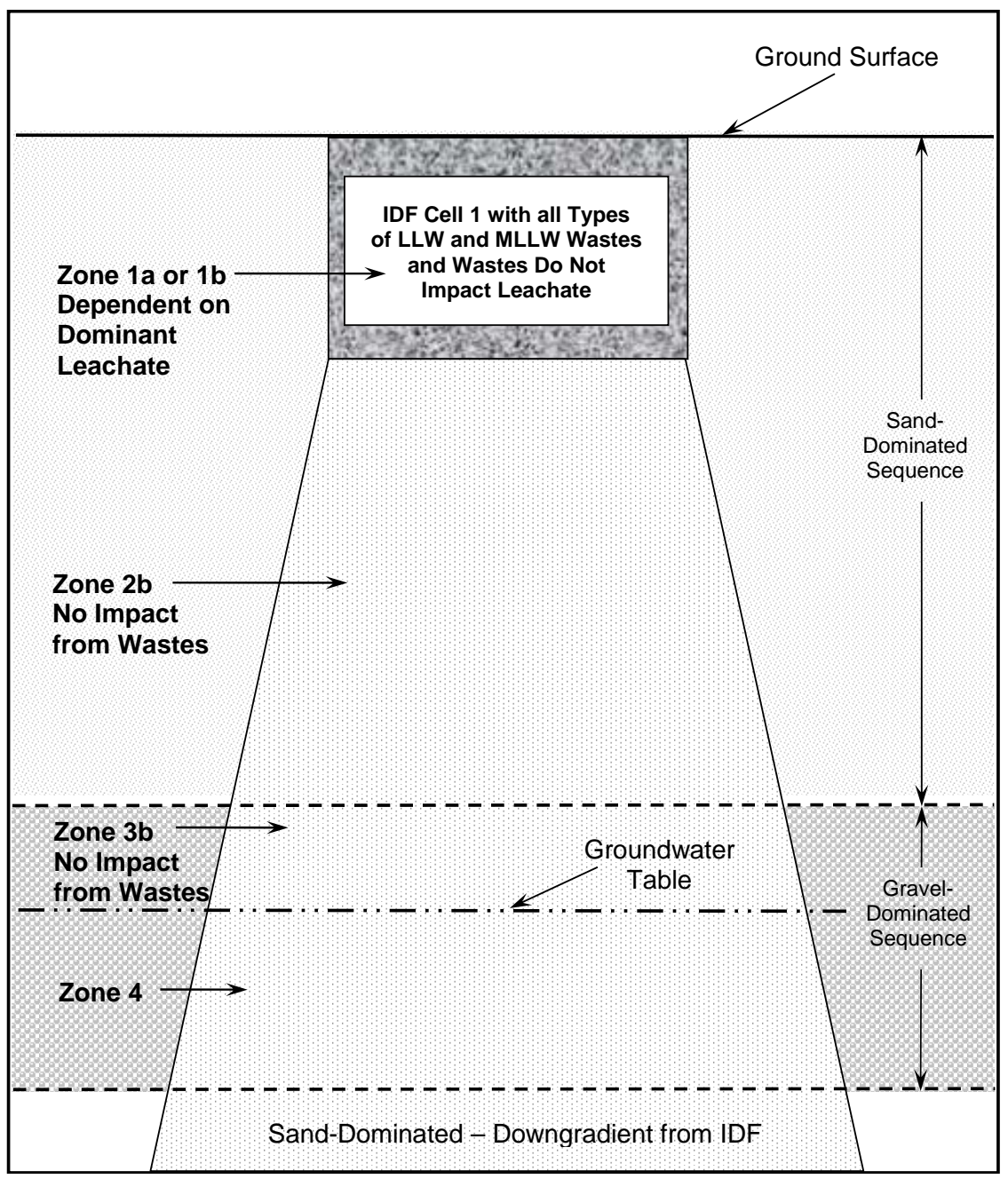

Figure 4.2. Schematic Representation (not to scale) of the Geochemical Zones for an IDF Cell (Cell 1) that Contains all Types of Wastes and Has Pore Fluid Dominated by Natural Recharge and Wastes that Do Not Leach to any Significant Extent

generate the $\mathrm{K}_{\mathrm{d}}$ values were appropriate for the IDF-specific zones. Consequently, expert opinion and geochemistry experience were used where non-site-specific data were used; rationale and experimental evidence to support the expert opinion are provided. In some cases, there were no generic data available and we were forced to use "expert judgment" to estimate values. The estimated values that have no actual measurements to defend the choices are identified.

Based on boreholes 299-E17-21 and 299-E24-21 and the geology data package (see Reidel 2004), the stratigraphy below the IDF site has two general sequences, a sand-dominated sequence that is divided into three layers (from shallow to deep L3, L2, L1) that exists from $\sim 0$ to $75 \mathrm{~m}$ below the surface, and a gravel-dominated sequence that exists from $\sim 75$ to $\sim 145 \mathrm{~m}$ below the surface (Reidel et al. 1998). The sand-dominated sequence (with the three designated layers L3, L2, and L1) has essentially no gravel, except for a few thin gravel lenses (Reidel et al. 1998). The deeper gravel-dominated sequence consists of $\sim 90 \%$ gravel. Gravel-corrected $K_{d}$ values $(g$ in Equation $2.6=0.9$ ) were used for radionuclides in the gravel-dominated sequence (Zones 3a, 3b, and 4 in Tables 4.1 and 4.2). Little information is available 


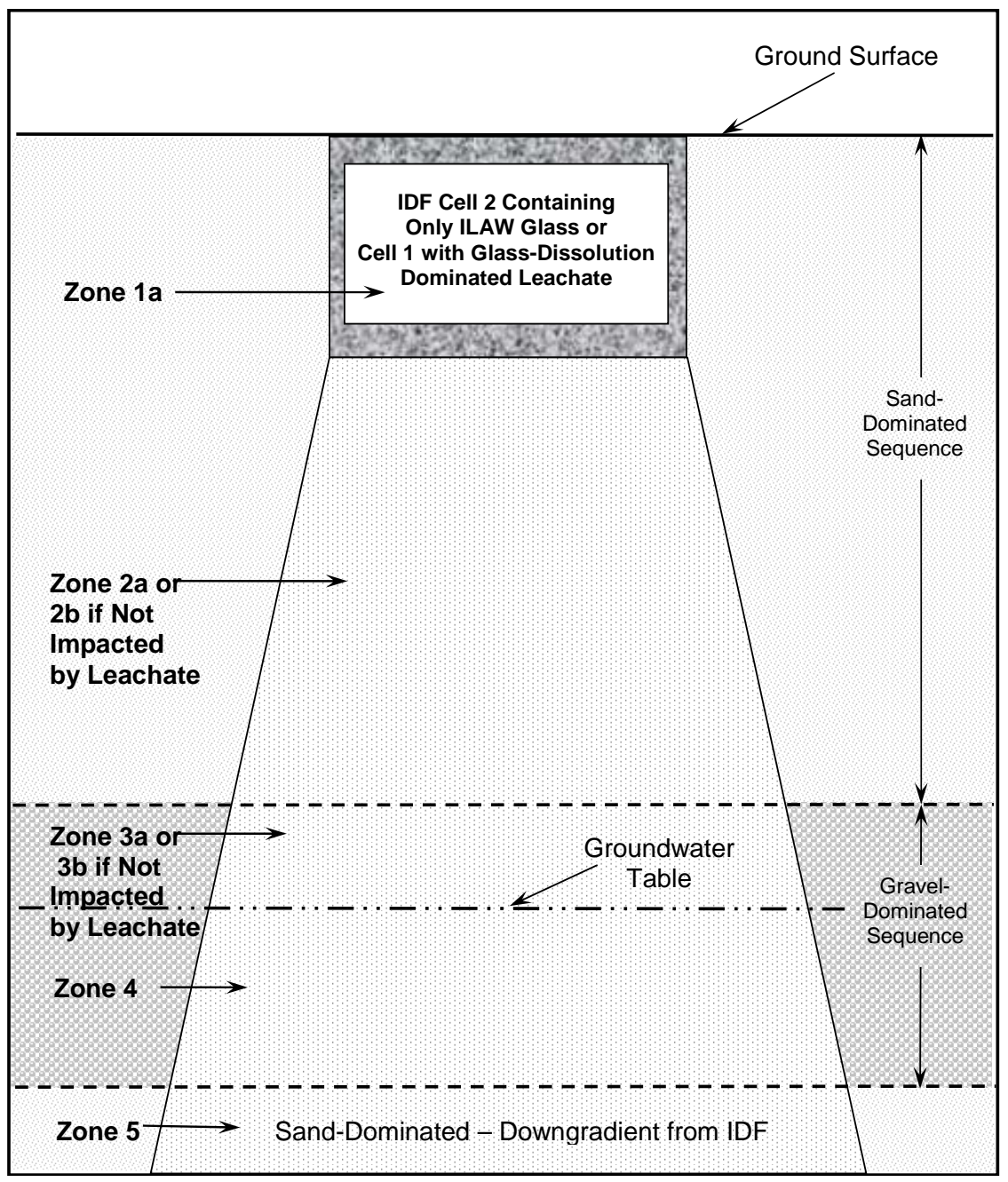

Figure 4.3. Schematic Representation (not to scale) of the Geochemical Zones for an IDF Cell (Cell 2) that Contains Only ILAW Glass or Glass-Dominated Cell 1 and Has Pore Fluid in Portions of Vadose Zone Dominated by Leachate from Glass Dissolution. (If impact from leachate does not affect entire vadose zone, Zones $2 \mathrm{~b}$ and $3 \mathrm{~b}$ are inserted as appropriate.)

about the properties and distribution of a mud layer that may exist within the gravel-dominated sequence at $\sim 110$ to $135 \mathrm{~m}$ below the ground surface. Unique $\mathrm{K}_{\mathrm{d}}$ values will not be assigned to this potential layer. This is a conservative simplification because reducing (sulfide odor is associated with some core samples) clays in this zone likely have a large sorption capacity as a result of a large cation-exchange capacity and surface area and a large potential for reductive precipitation. If this reducing mud layer were found to be present in a large area underneath the IDF site, it would warrant more attention, especially for the fate of the high-dose redox-sensitive contaminants, such as neptunium, selenium, technetium, and uranium, discussed in Section 3.0.

The conceptual details of each of the geochemical zones shown in Figures 4.1 through 4.3 are described below. 
Zone 1a-Near-Field/Vitrified Waste: The chemistry in this zone is dominated by the presence of glass leachate until all the glass has dissolved, which, based on the 2001 ILAW PA, is well beyond 10,000 years. Glass leachate has high $\mathrm{pH}(\sim 9.5)$, ionic strength (especially dissolved sodium and borate and dissolved carbonate/bicarbonate from equilibrating with atmospheric carbon dioxide), and radionuclide activity.

Radionuclide behavior in this zone is affected by unique solid phases dominated by glass, its weathering products, and backfill/engineered barrier materials. No contaminant adsorption will be considered on the glass. As reaction time increases, radionuclides will be incorporated and coprecipitated into secondary phases formed from glass dissolution. Accounting for these processes will be closely linked with the glass waste-form leaching data package (McGrail et al. 1999; Pierce et al. 2004). For the 2001 ILAW PA, no credit was taken for the coprecipitation of contaminants into the weathered glass secondary phases because adequate quantitative data for secondary minerals formed on the new British Nuclear Fuels Limited (BNFL) glass formulations had not been obtained. The long-term stability of the weathering products found in the short-term hydrothermal $\left(90^{\circ} \mathrm{C}\right)$ tests had also not been determined at that time. Recent studies by Mattigod et al. $(1998,2002,2003)$ on secondary phases formed from weathering other glass recipes indicate that the coprecipitation process for trace contaminants into the zeolites and clays that may occur. However, our understanding of the long-term fate of contaminants sequestered in newly formed secondary minerals from glass weathering is still incomplete, such that we will continue to recommend in the 2005 IDF PA that no credit be taken for sequestration via coprecipitation of contaminants in secondary minerals. The Subsurface Transport Over Reactive Multiphases (STORM) simulator (McGrail and Bacon 1998; Bacon et al. 2004) is being used to simulate contaminant release rates from the near field of the disposal facility for input to the ILAW and IDF performance assessments. If STORM calculations for the 2005 IDF PA suggest that discrete "pure" phase contaminant minerals form, for example U(VI) silicates, then credit should be taken because the stability of such minerals is better understood than mixed solid phase coprecipitates consisting of common major constituents and trace contents of contaminants of concern. The $\mathrm{K}_{\mathrm{d}}$ values and empirical solubility concentration limits in Zone 1a are found, respectively, in Tables 5.1 and 5.2.

Zone 1b-Near Field/Cementitious Secondary Waste: The chemistry in this zone is dominated by the presence of cement leachate and weathered cement minerals/compounds, which have high $\mathrm{pH}$, moderate ionic strength, and high-to-moderate radionuclide activity. The cement leachate chemistry will change with time as the cement degrades and weathers. The assemblage of secondary minerals that form is different from that formed from glass degradation; thus, the radionuclide behavior is expected to differ from Zone 1a. Zone $1 \mathrm{~b}$ also will contain backfill materials. The $\mathrm{K}_{\mathrm{d}}$ values and empirical solubility concentration limits in Zone $1 \mathrm{~b}$ are found, respectively, in Tables 5.3 and 5.4

The cement weathering times discussed in Krupka and Serne (1998) and Bradbury and Sarott (1995) were used to develop look-up tables for both $\mathrm{K}_{\mathrm{d}}$ values (onto degraded concrete/aggregate) and solubilities (in cement pore waters and leachates) as a function of time. Three temporal environments are considered: fresh cement with $\mathrm{pH} 12.5$, moderately aged cement with $\mathrm{pH} \sim 10.5$, and completely aged cement with $\mathrm{pH} \sim 8.5$. It is possible that the glass leachate will maintain a basic $\mathrm{pH}$ condition for tens of thousands of years such that only the first two time-dependent chemistries will be experienced in the IDF PA system conceptual model. 
The convention of Bradbury and Sarott (1995) for the three types of physicochemical environments through which all cements and concretes progress was used for the development of a preferred database of $\mathrm{K}_{\mathrm{d}}$ values and empirical solubility concentration limits. The following text describing the three temporal environments was taken from Krupka and Serne (1998).

Temporal Environment I: This environment occurs immediately after the cement hardens and is wetted by infiltrating water. The cement pore water is characterized as having a high $\mathrm{pH}(>12.5)$, high ionic strength, and high concentrations of potassium and sodium resulting from the dissolution of alkali impurities in the clinker phases. The high concentration of sodium is sometimes augmented by the dissolution of inorganic salts that have been solidified and buried in the disposal facility. Hydration is still continuing during Temporal Environment I with the formation of C-S-H gel (i.e., the $\mathrm{CaO}-\mathrm{SiO}_{2}-\mathrm{H}_{2} \mathrm{O}$ amorphous material that hardens and constitutes "cement") and portlandite $\left[\mathrm{Ca}(\mathrm{OH})_{2}\right]$. The composition of the cement pore fluid is at equilibrium with portlandite during this time. The duration of Temporal Environment I is relatively short when compared to the later "environments." Based on the modeling estimates discussed in Berner (1992), this environment may last for the first 100 to 10,000 years dependent on the rate of water influx. We proffer that for the IDF, Temporal Environment I will last for 5,000 to greater than 10,000 years in the very near field around cement-solidified wastes because recharge water rates will be quite low as controlled by the IDF surface cover.

Temporal Environment II: During this period, the soluble salts of the alkali metals are all dissolved. The $\mathrm{pH}$ of the cement pore water is initially controlled at a value of 12.5 by the solubility of portlandite, but decreases to 10.5 after portlandite is consumed. The C-S-H and portlandite are the major solid phases present. Temporal Environment II may last for a long time, and its duration depends on how much water percolates through the system and the mass of cement present in the disposal facility. The flux of water must dissolve all the slightly soluble portlandite before this environment changes. Using the estimates from Berner (1992), this environment may last from 100 to 10,000 years to 1,000 to 100,000 years. We proffer that for the IDF, Temporal Environment II will last for greater than 10,000 to 50,000 years in the very near field around cement-solidified wastes because recharge water rates will be quite low as controlled by the IDF surface cover.

Temporal Environment III: The concentration of portlandite has been reduced to such an extent by this period that the solubility of C-S-H now controls the $\mathrm{pH}$ of the cement pore fluid. The C-S-H starts to dissolve incongruently with a continual decrease in $\mathrm{pH}$. At the end of this evolution, Temporal Environment III can be conceptualized as leaving only silica $\left(\mathrm{SiO}_{2}\right)$ as the solubility control for the pore fluid $\mathrm{pH}$. The ionic strength of the cement pore fluid during this period is low and its initial $\mathrm{pH}$ is $\sim 10.5$ or less. For simplicity, the final end point of Temporal Environment III can be considered somewhat analogous to the geochemical conditions of the "normal" ambient soil environment. Of the three "environment" types, the duration of Temporal Environment II is thus the longest in which the pore fluid composition is influenced by the hydration and dissolution reactions of the cement components. We proffer that, for the IDF, Temporal Environment III will not occur until at least 10,000 years has elapsed in the very near field around cement-solidified wastes because recharge water rates will be quite low, controlled by the IDF surface cover. The end state of Temporal Environment III (essentially ambient sediment conditions) may never be reached in the near field of the IDF or even the entire vadose zone because of the impacts of slow dissolution of the ILAW glass. That is, the entire vadose zone under the IDF may always be slightly alkaline ( $\mathrm{pH} \sim 9$ ), dominated by sodium, soluble boron, and bicarbonate as opposed to normal ambient 
vadose zone pore waters that are dominated by calcium, magnesium, bicarbonate and sulfate. (See Serne et al. [2002a, 2004b] for background chemical compositions of Hanford sediment vadose zone pore waters.)

Zone 2a - Chemically Impacted Far Field in Sand Sequence: The chemistry in this zone has been impacted primarily by the ILAW glass leachate, such that the pore water has a moderate $\mathrm{pH}$ between 8 (background) and 9.5, a moderate ionic strength between 0.01 (background) to 0.1 , and low radionuclide activity (below empirical solubility concentration limits). This zone contains moderately altered Hanford formation sediment. This zone starts at the outside edge of the near-field IDF-impacted Zones 1a and 1b and ends at the start of the gravel-dominated sequence (Zone 3a) (e.g., see Figure 4.1). Contaminants will be controlled primarily by adsorption and not solubility constraints. Empirical solubility concentration limits in this zone should be considered if additional information becomes available that supports doing so. If the glass leachate and cement waste from leachates do evolve to less basic and lower ionic-strength chemical solutions at long times, then the $\mathrm{K}_{d}$ values in Zone $2 \mathrm{a}$ will approach those for Zone $2 \mathrm{~b}$. The $\mathrm{K}_{\mathrm{d}}$ values in Zone $2 \mathrm{a}$ are found in Table 5.5, which shows $\mathrm{K}_{\mathrm{d}}$ values for less than 2-mm sized sediments.

Zone $2 \mathrm{~b}$ - Far Field in Sand Sequence with Natural Recharge: The chemistry in this zone is assumed to not be affected by the leachates from solid waste or solidified concrete waste packages. The recharge water percolating around and through the IDF cell containing solid and cement-solidified wastes (Figure 4.2) resembles background vadose zone pore water laden with small concentrations of contaminants. The pore water has a moderate $\mathrm{pH} \sim 8$ (background), a moderate ionic strength between 0.01 (background) to 0.03 , and low radionuclide activity (below empirical solubility concentration limits). This zone starts at the outside edge of the near-field IDF-impacted Zones $1 \mathrm{a}$ and $1 \mathrm{~b}$ and ends at the start of the graveldominated sequence (Zone 3a [Figures 4.1 and 4.3] or Zone 3b/4 [Figure 4.2] dependent upon which IDF cell is being described). Contaminants will be controlled primarily by adsorption and not solubility constraints. The $\mathrm{K}_{\mathrm{d}}$ values in Zone $2 \mathrm{~b}$ are found in Table 5.6, which shows $\mathrm{K}_{\mathrm{d}}$ values for less than 2-mm sized sediments for natural Hanford Site groundwater.

Zone 3a-Chemically Impacted Far Field in Gravel Sequence: The chemistry in this zone has been affected by leachates from the glass wastes and perhaps cement waste forms (if large quantities are emplaced in IDF), such that its pore water has a moderate $\mathrm{pH}$ between 8 (background) and 10, a moderate ionic strength between 0.01 (background) to 0.1 , and low radionuclide activity (below empirical solubility concentration limits). This zone exists in the gravel-dominated sequence. The $\mathrm{K}_{\mathrm{d}}$ values in this zone will be identical to those for Zone $2 \mathrm{a}$, except that the $\mathrm{K}_{\mathrm{d}}$ values are gravel-corrected. If the glass leachate and cement waste form leachates do evolve to less basic and lower ionic-strength chemical solutions at long time frames, then the $\mathrm{K}_{\mathrm{d}}$ values in Zone 3a will approach those for Zone 4 at some future time. If the surface covers work as expected even during alteration back to natural sediment conditions, then infiltration rates are likely to be too low to completely leach and weather the glass and cementitious waste forms to their final aged state where they would meld mineralogically and chemically to ambient sediments. The gravel-corrected $\mathrm{K}_{\mathrm{dgc}}$ values in Zone $3 \mathrm{a}$ are found in Table 5.7.

Zone $3 \mathrm{~b}$ and 4 - Far Field in Gravel Sequence: Zone 3b (Figure 4.2) is located above the water table and Zone 4 (all figures in Section 4) is located below the water table. Both zones are in the $90 \%$ graveldominated sequence found below the IDF reserved portion of the Hanford Site (see Reidel 2004 for more discussion). The groundwater and non-impacted vadose zone pore water are assumed not to be impacted significantly by major constituents that leach from the waste forms, and thus the concentrations of major 
solutes are present at natural background levels. The water in this zone is assumed to be "significantly tainted" only by contaminants and not by major common constituents from leachates of the glass and/or cement waste forms. Hanford Site groundwater is dominated by calcium and bicarbonate and has a $\mathrm{pH}$ of 8 and an ionic strength of 0.005 to $0.01 \mathrm{M}$. The $\mathrm{K}_{\mathrm{d}}$ values in the look-up table for this zone will remain constant with time. This is equivalent to assuming that the salts emanating from Zones $1 \mathrm{a}$ and $1 \mathrm{~b}$ have been completely removed by the geomedia or diluted to insignificant levels when compared to natural groundwater by the time the solution reaches Zones $3 \mathrm{~b}$ and 4 . This is equivalent to assuming that the groundwater flow is sufficiently large that it will dilute IDF leachates to the point that no competitive effects exist from the waste form leachates. The $\mathrm{K}_{\mathrm{dgc}}$ values in Zones $3 \mathrm{~b}$ and 4 can be considered to be time invariant in our conceptual model and are listed in Table 5.8.

Zone 5 - Unconfined Far-Field Aquifer: This environment is found deep in the unconfined aquifer under the IDF facility and farther downgradient toward the Columbia River in the upper unconfined aquifer. We assume that the groundwater flow is sufficiently large that it will dilute IDF leachates to the point that no competitive effects exist from the waste form leachates. The $\mathrm{K}_{\mathrm{d}}$ values in the unconfined aquifer can be considered to be time invariant in our conceptual model. The $\mathrm{K}_{\mathrm{d}}$ values for the ambient unconfined aquifer in sand dominated (or at least gravel with less than $90 \%$ greater than 2 -mm sized particles) sediments are found in Table 5.9. 


\subsection{Summary Tables}

Geochemical input values for the geochemical zones described in Tables 4.1 through 4.3 and illustrated schematically in Figures 4.1 through 4.3 are presented in Tables 5.1 through 5.9, respectively. For Zones $1 \mathrm{a}$ and $1 \mathrm{~b}$, empirical solubility concentration limits are provided for some contaminants where appropriate. If the near-field solution concentration of a contaminant is above the "solubility limit," the empirical solubility concentration limit will be used to control the solution concentration; if the solution concentration is below this value, then the $\mathrm{K}_{\mathrm{d}}$ values will be used in the retardation factor equation to calculate solution concentrations. Four $\mathrm{K}_{\mathrm{d}}$ values are provided in each table cell: a reasonable conservative $K_{d}$, a "best" estimate (or most probable) $K_{d}$, and upper and lower $K_{d}$ limits. The reasonable conservative $\mathrm{K}_{\mathrm{d}}$ is a reasonable lower-bounding value that takes into consideration potential conditions that may enhance radionuclide migration. This estimate was usually identical to the lower value of the range. For a few situations, the lower limit was not selected as the reasonable conservative $\mathrm{K}_{\mathrm{d}}$ value because the lower limit value originated from a questionable experiment or the experimental conditions used to generate the value would yield a lower value than the conditions of the zone of interest merit. The "best" estimates are presented to provide guidance on what the most likely $\mathrm{K}_{\mathrm{d}}$ value is for a given condition. This was based primarily on some central value of the literature or laboratory $\mathrm{K}_{\mathrm{d}}$ values and on expert judgment. The concept of using a central value, the statistics, and some of the raw data involved in identifying this central value was presented by Kaplan and Serne (1995) for iodine, neptunium, selenium, technetium, and uranium. Newer Hanford- and IDF-specific $\mathrm{K}_{\mathrm{d}}$ data have been factored into the choice of the "best" estimate for all contaminants using the same concepts presented in Kaplan and Serne (1995). The range is provided to help in uncertainty estimates and sensitivity analyses. The distribution of $\mathrm{K}_{\mathrm{d}}$ values within this range is assumed to be a normal distribution.

For the empirical solubility concentration limits, only reasonable conservative and "best" estimate (or most probable) values are given. No ranges or solubility concentration distributions are given at this time. If the 2005 IDF PA shows that solubility constraints are important, then some effort will be undertaken to improve the uncertainty/sensitivity of future performance assessment calculations. Finally, supporting references for the selection of the various $\mathrm{K}_{\mathrm{d}}$ and empirical solubility concentration limits or estimates are provided in the tables. 
Table 5.1. $\quad K_{d}$ Values for Zone 1a - Near Field/Vitrified Waste ${ }^{(a)}$

\begin{tabular}{|c|c|c|c|c|}
\hline $\begin{array}{l}\text { Radio- } \\
\text { nuclide }\end{array}$ & $\begin{array}{l}\text { Reasonable } \\
\text { Conservative } \\
\mathbf{K}_{\mathrm{d}}(\mathrm{mL} / \mathrm{g})\end{array}$ & $\begin{array}{c}\text { "Best" } K_{d} \\
(\mathrm{~mL} / \mathrm{g})\end{array}$ & $\begin{array}{l}\mathrm{K}_{\mathrm{d}} \text { Range } \\
(\mathrm{mL} / \mathrm{g})\end{array}$ & Justification/References $^{(b)}$ \\
\hline $\begin{array}{l}{ }^{3} \mathrm{H}, \mathrm{Cl}, \mathrm{Tc} \\
\mathrm{Ru}, \mathrm{C}, \mathrm{N} \text { as } \\
\text { nitrate, } \\
\mathrm{Cr}(\mathrm{VI}), \mathrm{Nb}\end{array}$ & 0 & 0 & 0 to 1 & $\begin{array}{l}\mathrm{C}, \mathrm{Cl}, \mathrm{N} \text { as nitrate, } \mathrm{Cr}(\mathrm{VI}) \text { as chromate and Tc are anionic. }{ }^{3} \mathrm{H} \text { will move with } \mathrm{H}_{2} \mathrm{O} \text {. Ru has often been suggested as being } \\
\text { water coincident in tank leak scenarios based on gamma borehole logging. } \mathrm{C} \text { as carbonate in high } \mathrm{pH} \text { tank environments } \\
\text { is insoluble and combines with alkaline earths. To account for insolubility a } \mathrm{K}_{\mathrm{d}} \text { value }>0 \text { is appropriate but to keep C } \\
\text { from getting stuck permanently in this source (high impact) zone the value was set at } 0(1,2,3,9,10) \text {. A recent Tc } \mathrm{K}_{\mathrm{d}} \\
\text { measurement for a synthetic ILAW glass leachate and IDF sand sediment from } 299 \text {-E24-21 showed } 0 \mathrm{~mL} / \mathrm{g} \text { with high } \\
\text { reproducibility for triplicate tests (10). Limited information available for geochemical behavior of } \mathrm{Nb} \text {. Nb expected to be } \\
\text { anionic at } \mathrm{pH}>7 \text {; see discussion in Robertson et al. (13). }\end{array}$ \\
\hline I & 0.04 & 0.1 & $\begin{array}{c}0.04 \text { to } \\
0.16\end{array}$ & $\begin{array}{l}\text { Non-zero } K_{d} \text { values exist for this condition, } 1.04 \pm 0.02 \text { and } 1.07 \pm 0.03 \mathrm{~mL} / \mathrm{g} \text {, were measured in Hanford sediments in } \\
\text { high pH, high ionic-strength conditions }(8) \text {. But more recent sorption tests using IDF borehole sediment from 299-E24- } \\
21 \text { and a synthetic glass leachate showed } \mathrm{K}_{\mathrm{d}} \text { values ranged from } 0.04 \text { to } 0.16 \text {. These new values are chosen as most } \\
\text { realistic for Zone } 1 \mathrm{a}(10) \text {. }\end{array}$ \\
\hline $\mathrm{Se}$ & 0 & 1 & 0 to 3 & $\begin{array}{l}\text { (10) measured the } \mathrm{K}_{\mathrm{d}} \text { for selenate in synthetic glass leachate onto IDF borehole sediments and found non-zero values } \\
\text { consistently for } 6 \text { tests. Values ranged from } 1 \text { to } 3 \mathrm{~mL} / \mathrm{g} \text { with good precision. }\end{array}$ \\
\hline $\begin{array}{l}\mathrm{Ac}, \mathrm{Am}, \mathrm{Ce}, \\
\mathrm{Cm}, \mathrm{Eu}\end{array}$ & 2 & 5 & 2 to 10 & Estimated $(2,4)$ \\
\hline Cs & 1 & 1.5 & 1 to 25 & $\begin{array}{l}\text { Based on observations at T-106, }{ }^{137} \mathrm{Cs} \text { seemed to peak at } \sim 10 \mathrm{ft} \text { below the base (elevation) of the tank and nitrate at } \sim 80 \mathrm{ft} \text {. } \\
\text { This implies an in situ Rf of } \sim 8 \text { or a } \mathrm{K}_{\mathrm{d}} \text { value of } \sim 1 \text { or } 2 \mathrm{~mL} / \mathrm{g} \text { during the initial tank leak. The lack of cesium in } \\
\text { groundwater beneath tanks suggests it has not broken through. (7) measured a } \mathrm{K}_{\mathrm{d}} \text { of } 26 \mathrm{ml} / \mathrm{g} \text { for simulated REDOX tank } \\
\text { liquor. But the results are not consistent with inferred Cs migration using gamma borehole logging at SX tank farm (6). }\end{array}$ \\
\hline $\begin{array}{l}\mathrm{Co}, \mathrm{Ni}, \mathrm{Np}, \\
\mathrm{Pa}, \mathrm{Sn}\end{array}$ & 0.1 & 0.2 & 0.1 to 4 & Estimated (4). \\
\hline Sr, Ra & 4 & 15 & 4 to 70 & $\begin{array}{l}\text { Here it is assumed that caustic tank liquors are a surrogate for glass and cement leachate. Sr is known to be rather } \\
\text { insoluble in tank liquors and does not migrate through soils in tank liquor as rapidly as other cations (4). Using IDF } \\
\text { borehole specific sediment and synthetic glass leachate a value of } 70 \pm 1 \mathrm{~mL} / \mathrm{g} \text { was obtained (10). }\end{array}$ \\
\hline $\begin{array}{l}\text { Th, Zr, Pb, } \\
\mathrm{Pu}\end{array}$ & 5 & 10 & 5 to 100 & Estimated $(2,4)$. \\
\hline
\end{tabular}


Table 5.1. (contd)

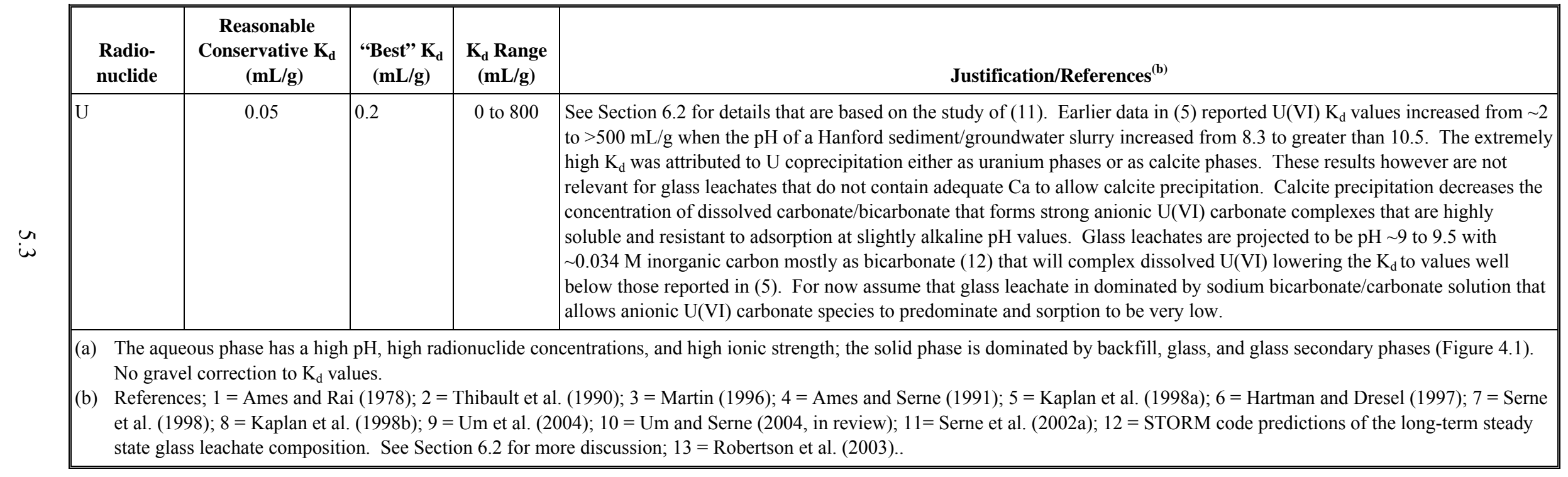


Table 5.2. Empirical Solubility Concentration Limits for Designated Solids in Zone 1a - Near Field/Vitrified Wastes ${ }^{(a)}$

\begin{tabular}{|c|c|c|c|}
\hline $\begin{array}{l}\text { Radio- } \\
\text { nuclide }\end{array}$ & $\begin{array}{c}\text { Reasonable } \\
\text { Conservative } \\
\text { Empirical Solubility } \\
\text { Concentration } \\
\text { Limit (M) } \\
\end{array}$ & $\begin{array}{l}\text { "Best" Empirical } \\
\text { Solubility } \\
\text { Concentration } \\
\text { Limit (M) }\end{array}$ & Justification/References $^{(\mathbf{b})}$ \\
\hline $\begin{array}{l}{ }^{3} \mathrm{H}, \mathrm{Cl}, \mathrm{Tc}, \mathrm{I}, \\
\mathrm{Se}, \mathrm{Ru}, \mathrm{C}, \mathrm{N} \\
\text { as nitrate and } \\
\mathrm{Cr} \text { as } \\
\text { chromate }\end{array}$ & --- & ----- & $\begin{array}{l}\text { At present, none of these contaminants have solubility constraints in glass leachate. Tc, } \mathrm{C}, \mathrm{Se}, \mathrm{Cl} \text {, and } \mathrm{I} \text { are anionic. } \\
{ }^{3} \mathrm{H} \text { is considered to be present as water. Ru may be present as the } \mathrm{RuO}_{4}^{-} \text {. }\end{array}$ \\
\hline $\begin{array}{l}\text { Ac, } \mathrm{Am}, \mathrm{Ce}, \\
\mathrm{Cm}, \mathrm{Eu},\end{array}$ & $1 \times 10^{-7}$ & $1 \times 10^{-9}$ & $\begin{array}{l}\text { Assume that glass leachate has high } \mathrm{pH} \text { and is similar to concrete leachates. Concrete leachate solubility values can } \\
\text { be realistically applied for hydrous oxide/metal hydroxides being the controlling solid. Solubility of these types } \\
\text { solids are dependent almost solely on } \mathrm{pH} \text { and nothing else in the pore fluids }(1,2,3)\end{array}$ \\
\hline Cs & ---- & ----- & $\begin{array}{l}\text { No solubility constraint is expected. But Cs could be incorporated into the glass weathering products. Ignoring this } \\
\text { should be conservative but not overly so, seeing as adsorption will prevent Cs from reaching the water table. }\end{array}$ \\
\hline $\mathrm{Co}, \mathrm{Ni}$ & $5 \times 10^{-4}$ & $5 \times 10^{-7}$ & $\begin{array}{l}\text { Assume that metal hydroxide is controlling solid and thus } \mathrm{pH} \text { is the only sensitive variable. There is data for } \\
\text { alkaline cement conditions and we will assume they hold for alkaline glass leachates }(1,2 \text {, and } 3) \text {. }\end{array}$ \\
\hline $\begin{array}{l}\mathrm{Nb}, \mathrm{Np}, \mathrm{Pa}, \\
\mathrm{Sn}\end{array}$ & $5 \times 10^{-4}$ & $5 \times 10^{-6}$ & $\begin{array}{l}\text { Assume that metal hydroxide is the controlling solid. There is empirical data in Ewart et al. (3) that predicts much } \\
\text { lower than thermodynamic predictions }(1,2,3) \text {. }\end{array}$ \\
\hline $\mathrm{Ra}$ & $1 \times 10^{-5}$ & $3 \times 10^{-6}$ & Ra sulfate is the controlling solid. Bayliss et al. (4) found no precipitation for Ra at $10^{-7} \mathrm{M}$ in concrete leachate. \\
\hline $\mathrm{Sr}$ & $2 \times 10^{-5}$ & $1 \times 10^{-7}$ & $\begin{array}{l}\text { Sr carbonate forms in cements }(1,2,3) \text { but for glass leachates we are not sure. These values may need to be revised } \\
\text { or not used in order to be conservative. }\end{array}$ \\
\hline $\begin{array}{l}\text { Th, } \mathrm{Zr}, \mathrm{Pb} \text {, } \\
\mathrm{Pu}\end{array}$ & $5 \times 10^{-7}$ & $1 \times 10^{-8}$ & $\begin{array}{l}\text { Assume solubility controlling phase of hydroxide/hydrous oxides for } \mathrm{Th}, \mathrm{Zr}, \mathrm{Pu} \text { and hydroxycarbonates for } \mathrm{Pb} \text {. } \\
\text { There is data for } \mathrm{Th} \text { and } \mathrm{Pu} \text { in cement leachates under oxidizing and reducing conditions. We chose the oxidizing } \\
\text { conditions (3). Other assessments of these values are presented in }(1,2) \text {. }\end{array}$ \\
\hline $\mathrm{U}$ & $1 \times 10^{-6}$ & ---- & $\begin{array}{l}\text { For the } 2005 \text { performance assessment, no empirical solubility concentration limit on glass leachate will be used } \\
\text { unless STORM calculations predict a known pure U phase is forming. In the } 2001 \text { performance assessment, the } \\
\text { STORM calculations did not identify any pure U solid phase for which its solubility was exceeded in the leachates. }\end{array}$ \\
\hline \multicolumn{4}{|c|}{$\begin{array}{l}\text { (a) The aqueous phase has a high } \mathrm{pH} \text {, high radionuclide concentrations, and high ionic strength; the solid phase is dominated by backfill, glass, and glas } \\
\text { (Table } 4.3 \text { and Figure 4.3). No gravel correction to } \mathrm{K}_{\mathrm{d}} \text { values. } \\
\text { (b) References: } 1=\text { Krupka and Serne (1998); } 2 \text { = Brady and Kozak (1995); } 3 \text { = Ewart et al. (1992); } 4 \text { = Bayliss et al. (1989); } 5=\text { Kaplan et al. (1998a) }\end{array}$} \\
\hline
\end{tabular}


Table 5.3. $\quad K_{d}$ Values for Zone $1 b-$ Near Field/Cementitious Secondary Wastes ${ }^{(a)}$

\begin{tabular}{|c|c|c|c|c|c|c|c|c|c|c|}
\hline \multirow[b]{2}{*}{$\begin{array}{l}\text { Radio- } \\
\text { nuclide }\end{array}$} & \multicolumn{3}{|c|}{$\begin{array}{l}\text { Young Concrete } \\
\quad(\mathrm{pH} \sim 12.5)\end{array}$} & \multicolumn{3}{|c|}{$\begin{array}{c}\text { Moderately Aged Concrete (pH } \\
\text { 10.5) }\end{array}$} & \multicolumn{3}{|c|}{$\begin{array}{l}\text { Aged Concrete } \\
\qquad(\mathrm{pH} \sim 8.5)\end{array}$} & \multirow[t]{2}{*}{ Justification/References $^{(\mathbf{b})}$} \\
\hline & $\begin{array}{c}\text { Conservative } \\
\mathbf{K}_{\mathbf{d}}(\mathbf{m L} / \mathbf{g}) \\
\end{array}$ & $\begin{array}{c}\begin{array}{c}\text { “Best” } K_{d} \\
(\mathrm{~mL} / \mathrm{g})\end{array} \\
\end{array}$ & $\begin{array}{c}\mathrm{K}_{\mathrm{d}} \text { Range } \\
(\mathrm{mL} / \mathrm{g})\end{array}$ & $\begin{array}{l}\text { Conser- } \\
\text { vative } K_{d} \\
(\mathbf{m L} / \mathbf{g})\end{array}$ & \begin{tabular}{|c|}
$\begin{array}{c}\text { Best” } K_{d} \\
(\mathrm{~mL} / \mathrm{g})\end{array}$ \\
\end{tabular} & \begin{tabular}{|c|}
$\begin{array}{c}K_{d} \text { Range } \\
(\mathrm{mL} / \mathrm{g})\end{array}$ \\
\end{tabular} & $\begin{array}{l}\text { Conser- } \\
\text { vative } K_{d} \\
(\mathbf{m L} / \mathbf{g})\end{array}$ & \begin{tabular}{|c|} 
“Best” $\mathbf{K}_{\mathrm{d}}$ \\
$(\mathrm{mL} / \mathrm{g})$
\end{tabular} & $\begin{array}{l}\mathrm{K}_{\mathrm{d}} \text { Range } \\
(\mathrm{mL} / \mathrm{g})\end{array}$ & \\
\hline $\begin{array}{l}{ }^{3} \mathrm{H}, \mathrm{Tc}, \mathrm{N} \text { as } \\
\text { nitrate and } \\
\mathrm{Cr} \text { as } \\
\text { chromate }\end{array}$ & 0 & 0 & 0 to 2 & 0 & 0 & 0 to 2 & 0 & 0 & 0 to 1 & $\begin{array}{l}\text { Tc and chromate may be slightly sorbed to concrete, } \\
\text { albeit, very little }(1,2,3,4,5,6) \text {. }\end{array}$ \\
\hline $\mathrm{Cl}$ & 0.8 & 8 & 0.8 to 25 & 1 & 2 & 1 to 5 & 0 & 0 & 0 to 1 & $\begin{array}{l}\text { Estimated. French sulfate-resistant cement had a Cl } \\
\mathrm{K}_{\mathrm{d}} \text { of } 25 \mathrm{~mL} / \mathrm{g}(7) . \mathrm{Cl} \text { diffused through cement disks } \\
\text { slower than }{ }^{3} \mathrm{H}(8) . \mathrm{Cl} \mathrm{K} \mathrm{K}_{\mathrm{d}} \text { to cement powder after } 24- \\
\text { hr contact time }=0.8 \mathrm{~mL} / \mathrm{g}(9)\end{array}$ \\
\hline $\mathrm{I}$ & 10 & 20 & 10 to 150 & 5 & 8 & 5 to 15 & 1 & 2 & 1 to 5 & $\begin{array}{l}\text { Iodide } \mathrm{K}_{\mathrm{d}} \text { values of seven types of concrete samples } \\
\text { increased gradually over three months, than leveled } \\
\text { off to between } 25 \text { and } 130 \mathrm{~mL} / \mathrm{g}(10,11) \text {. After } 300 \\
\text { days contact with various cements, } 77 \text { to } 98 \% \text { iodide } \\
\text { and even more iodate sorbed. I- sorption to cement is } \\
\text { very concentration dependent: at } 10^{-8} \mathrm{I}^{-} \mathrm{K}_{\mathrm{d}}=1,000 \\
\mathrm{~mL} / \mathrm{g} \text { at } 10^{-2} \mathrm{M} \mathrm{I} \mathrm{K}_{\mathrm{d}}=1.4 \mathrm{~mL} / \mathrm{g}(12) \text {. I- sorption to } \\
\text { cement is highly reversible }(12) \text {. Iodine } \mathrm{K}_{\mathrm{d}} \text { in } 7 \text { day } \\
\text { contact }=2.5 \mathrm{~mL} / \mathrm{g} \text {; after } 30 \text { days } 7.7 \mathrm{~mL} / \mathrm{g}(13) \text {. }\end{array}$ \\
\hline $\mathrm{C}$ & 10 & 20 & $\begin{array}{l}10 \text { to } \\
1,000\end{array}$ & 5 & 10 & 5 to 1,000 & 0 & 0 & 0 & $\begin{array}{l}\text { Carbon-14 chemistry is complicated in cement; C } \\
\text { coprecipitation more important process in concrete } \\
\text { than adsorption. See solubility discussion in } \\
\text { Table } 5.4 \text { and (18). }\end{array}$ \\
\hline \begin{tabular}{|l}
$\mathrm{Ac}, \mathrm{Am}, \mathrm{Ce}$ \\
$\mathrm{Cm}, \mathrm{Eu}$
\end{tabular} & 2,000 & 5,000 & $\begin{array}{c}2,000 \text { to } \\
40,000\end{array}$ & 1,000 & 5,000 & $\begin{array}{c}1,000 \text { to } \\
30,000\end{array}$ & 400 & 500 & $\begin{array}{l}400 \text { to } \\
1,000\end{array}$ & $\begin{array}{l}\text { Trivalent metal } \mathrm{K}_{d} \text { values to concrete exceed those to } \\
\text { sediments }(1) . \text { Am } \mathrm{K}_{\mathrm{d}}>10,000 \mathrm{~mL} / \mathrm{g}(14) \text {. Am } \mathrm{K}_{\mathrm{d}} \\
\sim 12,000 \mathrm{~mL} / \mathrm{g} \text { based on diffusion tests of cement }(15) \text {. } \\
\text { Am } \mathrm{K}_{\mathrm{d}} \text { values ranged from } 2,500 \text { to } 35,000 \mathrm{~mL} / \mathrm{g} \text { for } \\
\text { seven fresh (unaged)-concrete blends }(10,11) \text {. Am } \\
\mathrm{K}_{\mathrm{d}} \text { for } 65 \text {-yr old concrete sample }=10,000(10,11) \text {. } \\
\text { Fresh cement Am- } \mathrm{K}_{\mathrm{d}}=2000 \text { for } 24-\mathrm{hr} \text { contact time } \\
(9) \text {. Eu- } \mathrm{K}_{\mathrm{d}}=2,400 \mathrm{~mL} / \mathrm{g} \text { for } 24 \mathrm{hr} \text { contact time }(9) \text {. } \\
\text { Very large } \mathrm{K}_{\mathrm{d}} \text { values may reflect precipitation } \\
\text { reactions that occurred during the adsorption } \\
\text { measurements }(24) .\end{array}$ \\
\hline $\begin{array}{l}\text { Co, Ni, Ra, } \\
\text { Sn }\end{array}$ & 70 & 100 & 70 to 250 & 70 & 100 & 70 to 250 & 7 & 10 & 7 to 25 & $\begin{array}{l}\text { Co- } \mathrm{K}_{\mathrm{d}}=4,300 \mathrm{~mL} / \mathrm{g}(9) \\
\mathrm{Ni}-\mathrm{K}_{\mathrm{d}} \text { for } 3 \text { cement types: } 500 \text { to } 3000 \mathrm{~mL} / \mathrm{g} \mathrm{(16)} \\
1500 \mathrm{~mL} / \mathrm{g}(9) \text {, and } 500 \text { to } 3,000 \mathrm{~mL} / \mathrm{g}(17)\end{array}$ \\
\hline
\end{tabular}


Table 5.3. (contd)

\begin{tabular}{|c|c|c|c|c|c|c|c|c|c|c|}
\hline \multirow[b]{2}{*}{$\begin{array}{l}\text { Radio- } \\
\text { nuclide }\end{array}$} & \multicolumn{3}{|c|}{$\begin{array}{l}\text { Young Concrete } \\
\quad(\mathrm{pH} \sim 12.5)\end{array}$} & \multicolumn{3}{|c|}{$\begin{array}{c}\text { Moderately Aged Concrete (pH } \\
\sim 10.5)\end{array}$} & \multicolumn{3}{|c|}{$\begin{array}{l}\text { Aged Concrete } \\
\quad(\mathrm{pH} \sim 8.5)\end{array}$} & \multirow[t]{2}{*}{ Justification/References $^{(\mathbf{b})}$} \\
\hline & $\begin{array}{c}\text { Conservative } \\
\mathbf{K}_{\mathrm{d}}(\mathrm{mL} / \mathrm{g})\end{array}$ & $\begin{array}{c}\text { “Best”" } K_{d} \\
(\mathrm{~mL} / \mathrm{g})\end{array}$ & $\begin{array}{c}K_{d} \text { Range } \\
(\mathrm{mL} / \mathrm{g})\end{array}$ & $\begin{array}{c}\text { Conser- } \\
\text { vative } K_{d} \\
(\mathrm{~mL} / \mathrm{g})\end{array}$ & $\left|\begin{array}{c}\text { "Best" } K_{\mathrm{d}} \\
(\mathrm{mL} / \mathrm{g})\end{array}\right|$ & $\begin{array}{c}\mathrm{K}_{\mathrm{d}} \text { Range } \\
(\mathrm{mL} / \mathrm{g})\end{array}$ & $\begin{array}{c}\text { Conser- } \\
\text { vative } K_{d} \\
(\mathrm{~mL} / \mathrm{g})\end{array}$ & $\left|\begin{array}{c}\text { "Best" } K_{\mathrm{d}} \\
(\mathrm{mL} / \mathrm{g})\end{array}\right|$ & $\begin{array}{c}\mathrm{K}_{\mathrm{d}} \text { Range } \\
(\mathrm{mL} / \mathrm{g})\end{array}$ & \\
\hline Cs & 2 & 3 & 2 to 5 & 20 & 30 & 20 to 50 & 20 & 30 & 20 to 50 & \begin{tabular}{|l|} 
Cs $\mathrm{K}_{\mathrm{d}}$ values in hardened HTS cement discs, $\mathrm{pH}$ \\
$\sim 13.3$, were $3 \mathrm{~mL} / \mathrm{g}(7)$. Cs $\mathrm{K}_{\mathrm{d}}$ values of $0.2 \mathrm{~mL} / \mathrm{g}$ \\
were measured in hardened sulfate resisting cement \\
(12). Many authors have reported increase sorption at \\
pH $\sim 12.5$ (13, reviewed by 23$)$.
\end{tabular} \\
\hline $\mathrm{Nb}$ & 0 & 40 & 0 to 6,000 & 0 & 40 & 0 to 3,500 & 0 & 4 & 0 to 600 & $\begin{array}{l}\mathrm{Nb} \text { sorption data limited but suggests high sorption in } \\
\text { fresh cement }(22,23) \text {. }\end{array}$ \\
\hline $\mathrm{Np}, \mathrm{Pa}$ & 1,400 & 2,000 & $\begin{array}{l}1,400 \text { to } \\
10,000\end{array}$ & 1,400 & 2,000 & $\begin{array}{c}1,400 \text { to } \\
10,000\end{array}$ & 140 & 200 & 140 to 500 & \begin{tabular}{|l|} 
The dominant protactinium species is assumed to be \\
$\mathrm{Pa} \mathrm{O}_{2}^{+} . \mathrm{NpO}_{2}^{+}$is assumed to be a reasonable analog \\
$(19)$. Np sorption test to seven different 65 -yr old \\
cements using cement pore water reached steady state \\
after 30 days, $\mathrm{K}_{\mathrm{d}}$ values ranged from 1,500 to 9,500 \\
$\mathrm{~mL} / \mathrm{g}(10,11)$. User is cautioned that very large \\
$\mathrm{K}_{\mathrm{d}}$ values may reflect precipitation reactions that \\
occurred during the adsorption measurements (24).
\end{tabular} \\
\hline $\mathrm{Ru}, \mathrm{Se}$ & 1 & 2 & 1 to 800 & 1 & 2 & 1 to 100 & 0 & 1 & 0 to 300 & $\begin{array}{l}\text { Estimated. Dominant species for Se and Ru were } \\
\text { assumed to } \mathrm{SeO}_{4}{ }^{2-} \text { and } \mathrm{RuO} \mathrm{O}_{4}{ }^{2-} \text { respectively }(19) \text {. Ru } \\
\mathrm{K}_{\mathrm{d}} \text { values in Hanford sediment (not concrete) did not } \\
\text { change systematically with } \mathrm{pH} \text {; at } \mathrm{pH} 8.5 \text { the } \mathrm{K}_{\mathrm{d}} \text { value } \\
\text { was } 274 \mathrm{~mL} / \mathrm{g} \text {; at } \mathrm{pH} 10.4,44 \mathrm{~mL} / \mathrm{g} \text {; and at } \mathrm{pH} 14 \text {, } \\
752 \mathrm{~mL} / \mathrm{g}(21) \text {. Using a pH } 12 \text { simulated tank waste } \\
\text { solution and Hanford sediment, } \mathrm{K}_{\mathrm{d}} \text { values for } \mathrm{Ru} \\
\text { ranged from } 2.14 \text { to } 0 \mathrm{~mL} / \mathrm{g} \text {, averaging } \sim 0.8 \mathrm{~mL} / \mathrm{g} \\
(20) \text {. Sulfate may be used as an analog for selenate } \\
\text { chemical behavior in concrete. Sulfate (or sulfite) is } \\
\text { often included in concrete mixes, and therefore it } \\
\text { would be expected to be retained strongly by } \\
\text { concrete, primarily by coprecipitation constraints. } \\
\text { Selenate adsorption, independent of precipitation } \\
\text { processes, would be expected to be rather large. }\end{array}$ \\
\hline
\end{tabular}


Table 5.3. (contd)

\begin{tabular}{|c|c|c|c|c|c|c|c|c|c|c|}
\hline \multirow[b]{2}{*}{$\begin{array}{l}\text { Radio- } \\
\text { nuclide }\end{array}$} & \multicolumn{3}{|c|}{$\begin{array}{l}\text { Young Concrete } \\
\quad(\mathrm{pH} \sim 12.5)\end{array}$} & \multicolumn{3}{|c|}{$\begin{array}{c}\text { Moderately Aged Concrete (pH } \\
\sim 10.5)\end{array}$} & \multicolumn{3}{|c|}{$\begin{array}{l}\text { Aged Concrete } \\
\text { (pH 8.5) }\end{array}$} & \multirow[t]{2}{*}{ Justification/References $^{(\mathbf{b})}$} \\
\hline & $\begin{array}{c}\text { Conservative } \\
K_{d}(\mathrm{~mL} / \mathrm{g})\end{array}$ & \begin{tabular}{|l} 
"Best” $K_{d}$ \\
$(\mathrm{~mL} / \mathrm{g})$
\end{tabular} & $\begin{array}{c}K_{d} \text { Range } \\
(\mathrm{mL} / \mathrm{g})\end{array}$ & $\begin{array}{c}\text { Conser- } \\
\text { vative } K_{d} \\
(\mathrm{~mL} / \mathrm{g})\end{array}$ & $\begin{array}{c}\text { “Best” } K_{d} \\
(\mathbf{m L} / \mathrm{g})\end{array}$ & $\begin{array}{c}K_{d} \text { Range } \\
(\mathrm{mL} / \mathrm{g})\end{array}$ & $\begin{array}{c}\text { Conser- } \\
\text { vative } K_{d} \\
(\mathbf{m L} / g)\end{array}$ & $\mid \begin{array}{c}\text { “Best” } \mathbf{K}_{\mathrm{d}} \\
(\mathrm{mL} / \mathrm{g})\end{array}$ & $\begin{array}{c}\mathbf{K}_{\mathrm{d}} \text { Range } \\
(\mathrm{mL} / \mathbf{g})\end{array}$ & \\
\hline $\mathrm{Pb}, \mathrm{Pu}, \mathrm{Th}$ & 1,000 & 5,000 & $\begin{array}{l}1,000 \text { to } \\
10,000\end{array}$ & 1,000 & 5,000 & $\begin{array}{c}1,000 \text { to } \\
10,000\end{array}$ & 100 & 500 & $\begin{array}{l}100 \text { to } \\
1,000\end{array}$ & $\begin{array}{l}\text { Estimated. Using three } 65 \text {-yr-old crushed concrete } \\
\text { samples and seven fresh concrete samples, Th- } \mathrm{K}_{\mathrm{d}} \\
\text { values were } 2,500 \text { to } 5,500 \mathrm{~mL} / \mathrm{g}(10,11) \text {. Th- } \mathrm{K}_{\mathrm{d}} \\
\text { values were: consistently less than Am- } \mathrm{K}_{\mathrm{d}} \text { values, } \\
\text { greater than } \mathrm{U}-\mathrm{K}_{\mathrm{d}} \text { values, and very similar to Np Pu } \\
\mathrm{K}_{\mathrm{d}} \text { values }(10,11) . \mathrm{Pu}-\mathrm{K}_{\mathrm{d}} \text { values ranged from } 1,000 \\
\text { to } 12,000 \mathrm{~mL} / \mathrm{g}(10,11) \text {. Concrete containing } \\
\text { reducing agents }(\mathrm{BFS}) \text { did not have greater Pu } \mathrm{K}_{\mathrm{d}} \\
\text { values than those that did not contain reducing } \\
\text { agents. High } \mathrm{K}_{\mathrm{d}} \text { values are attributed to high } \\
\text { solubility of Pu in high pH solutions, not to } \\
\text { adsorption/ absorption processes }(22) \text {. }\end{array}$ \\
\hline $\mathrm{U}$ & 700 & 1,000 & $\begin{array}{l}700 \text { to } \\
2,500\end{array}$ & 700 & 1,000 & $\begin{array}{l}700 \text { to } \\
2,500\end{array}$ & 70 & 100 & 70 to 250 & $\begin{array}{l}\mathrm{U}(\mathrm{VI})-\mathrm{K}_{\mathrm{d}} \text { values for seven types of cement }=350 \text { to } \\
13,000, \text { average }=\sim 1000 \text { and median }=1,400 \mathrm{~mL} / \mathrm{g} \\
(10,11) .\end{array}$ \\
\hline \multicolumn{11}{|c|}{ 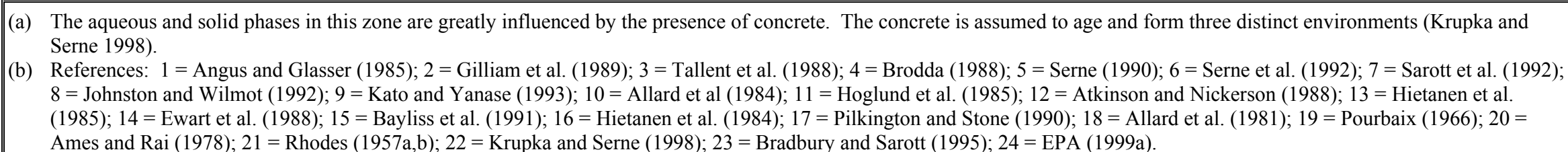 } \\
\hline
\end{tabular}


Table 5.4. Empirical Solubility Concentration Limits for Designated Solids for Zone $1 \mathrm{~b}-$ Near Field/Cementitious Secondary Wastes ${ }^{(a)}$

\begin{tabular}{|c|c|c|c|c|c|c|c|}
\hline \multirow[b]{2}{*}{$\begin{array}{l}\text { Radio- } \\
\text { nuclide }\end{array}$} & \multicolumn{2}{|c|}{$\begin{array}{l}\text { Young Concrete } \\
\quad(\mathrm{pH} \sim 12.5)\end{array}$} & \multicolumn{2}{|c|}{$\begin{array}{c}\text { Moderately Aged Concrete (pH } \\
\sim 10.5)\end{array}$} & \multicolumn{2}{|c|}{$\begin{array}{l}\text { Aged Concrete } \\
\quad(\mathbf{p H} \sim 8.5)\end{array}$} & \multirow[b]{2}{*}{ Justification/References ${ }^{(\mathbf{b})}$} \\
\hline & $\begin{array}{c}\text { Conservative } \\
\text { (M) }\end{array}$ & $\begin{array}{l}\text { “Best” Solubility } \\
\text { Concentration } \\
\text { Limit (M) }\end{array}$ & $\begin{array}{c}\text { Conser- } \\
\text { vative (M) }\end{array}$ & $\begin{array}{l}\text { "Best" Solubility } \\
\text { Concentration } \\
\text { Limit (M) }\end{array}$ & $\begin{array}{c}\text { Conser- } \\
\text { vative (M) }\end{array} \mid$ & $\begin{array}{l}\text { “Best” Solubility } \\
\text { Concentration } \\
\text { Limit (M) }\end{array}$ & \\
\hline $\begin{array}{l}{ }^{3} \mathrm{H},{ }^{36} \mathrm{Cl}, \\
\mathrm{Tc}, \mathrm{I}, \mathrm{N}, \\
\mathrm{Ru}, \mathrm{Se}\end{array}$ & $\begin{array}{c}-- \\
-1\end{array}$ & $\begin{array}{c}-- \\
-1\end{array}$ & $\begin{array}{c}-- \\
\end{array}$ & $\begin{array}{c}-- \\
\end{array}$ & $\begin{array}{c}-- \\
-1\end{array}$ & $\begin{array}{c}-- \\
-1\end{array}$ & $\begin{array}{l}\text { It was assumed that no solubility constraints exist } \\
\text { for these species, although there could be some } \\
\text { isotope exchange into cement and secondary } \\
\text { minerals. }\end{array}$ \\
\hline C & $10^{-5}$ & $10^{-6}$ & $10^{-3}$ & $10^{-4}$ & $10^{-2}$ & $10^{-3}$ & $\begin{array}{l}\text { Estimated. }{ }^{14} \mathrm{C} \text { chemistry is complicated in } \\
\text { cement; } \mathrm{C} \text { coprecipitation more important process } \\
\text { in concrete than adsorption. Calcite will be a } \\
\text { good controlling solid and the }{ }^{14} \mathrm{C} \text { will be } \\
\text { isotopically exchanged with stable } \mathrm{C} \text { For young } \\
\text { concrete assume that portlandite controls Ca to } 6 \\
\text { x } 10^{-3} \mathrm{M} \text {. For moderately aged cement and aged } \\
\text { cement that the Ca is controlled at } 10^{-2} \mathrm{M} \text { by some } \\
\text { undefined reactions. }\end{array}$ \\
\hline \begin{tabular}{|l}
$\mathrm{Ac}, \mathrm{Am}$, \\
$\mathrm{Ce}, \mathrm{Cm}$, \\
$\mathrm{Eu}$
\end{tabular} & $1 \times 10^{-7}$ & $1 \times 10^{-9}$ & $3 \times 10^{-7}$ & $3 \times 10^{-8}$ & $1 \times 10^{-5}$ & $1 \times 10^{-7}$ & $\begin{array}{l}\text { Known cement values can be realistically applied } \\
\text { for hydrous oxide/metal hydroxides being the } \\
\text { controlling solid. These solids are dependent } \\
\text { almost solely on pH, and nothing else in the pore } \\
\text { fluids }(1,2,3) \text {. }\end{array}$ \\
\hline $\mathrm{Cr}$ & --- & --- & --- & --- & --- & --- & $\begin{array}{l}\text { It was assumed that no solubility constraints exist } \\
\text { for this species. Though solubility data are not } \\
\text { available, a recent characterization study (7) } \\
\text { indicated the presence chromate-enriched } \\
\text { ettringite }\left(\mathrm{Ca}_{6} \mathrm{Al}_{2}\left((\mathrm{~S}, \mathrm{Cr}) \mathrm{O}_{4}\right)_{2}(\mathrm{OH})_{12} \cdot 26 \mathrm{H}_{2} \mathrm{O}\right) \text { and } \\
\text { hydrocalumite }\left(3 \mathrm{CaO} \cdot \mathrm{Al}_{2} \mathrm{O}_{3} \cdot \mathrm{CaCrO}_{4} \cdot \mathrm{nH}_{2} \mathrm{O}\right) \text { in } \\
\mathrm{Cr}(\mathrm{VI}) \text {-contaminated concrete from a former } \\
\text { hard-chrome plating facility. }\end{array}$ \\
\hline $\mathrm{Co}, \mathrm{Ni}$ & $5 \times 10^{-4}$ & $5 \times 10^{-7}$ & $5 \times 10^{-4}$ & $1 \times 10^{-6}$ & $1 \times 10^{-3}$ & $2 \times 10^{-5}$ & $\begin{array}{l}\text { Assume that metal hydroxide is controlling solid } \\
\text { and thus } \mathrm{pH} \text { is the only sensitive variable. There } \\
\text { is data for alkaline cement conditions and } \\
\text { predictions for groundwater (aged cement end } \\
\text { member) }(1,2,3) \text {. }\end{array}$ \\
\hline $\begin{array}{l}\mathrm{Nb}, \mathrm{Np} \\
\mathrm{Pa}, \mathrm{Sn}\end{array}$ & $5 \times 10^{-4}$ & $5 \times 10^{-6}$ & $1 \times 10^{-3}$ & $5 \times 10^{-4}$ & $1 \times 10^{-3}$ & $5 \times 10^{-4}$ & $\begin{array}{l}\text { Assume that metal hydroxide is the controlling } \\
\text { solid. There is empirical data in Ewart et al. (3) } \\
\text { that predicts much lower than thermodynamic } \\
\text { predictions }(1,2,3) \text {. }\end{array}$ \\
\hline
\end{tabular}


Table 5.4. (contd)

\begin{tabular}{|c|c|c|c|c|c|c|c|}
\hline \multirow[b]{2}{*}{$\begin{array}{l}\text { Radio- } \\
\text { nuclide }\end{array}$} & \multicolumn{2}{|c|}{$\begin{array}{l}\text { Young Concrete } \\
\quad(\mathbf{p H} \sim 12.5)\end{array}$} & \multicolumn{2}{|c|}{$\begin{array}{c}\text { Moderately Aged Concrete (pH } \\
\text { 10.5) }\end{array}$} & \multicolumn{2}{|c|}{$\begin{array}{l}\text { Aged Concrete } \\
\quad(\mathrm{pH} \sim 8.5)\end{array}$} & \multirow[b]{2}{*}{ Justification/References ${ }^{(\mathbf{b})}$} \\
\hline & $\begin{array}{l}\text { Conservative } \\
\text { (M) }\end{array}$ & $\begin{array}{l}\text { “Best” Solubility } \\
\text { Concentration } \\
\text { Limit (M) }\end{array}$ & $\begin{array}{c}\text { Conser- } \\
\text { vative }(M)\end{array}$ & $\begin{array}{l}\text { “Best" Solubility } \\
\text { Concentration } \\
\text { Limit (M) }\end{array}$ & $\begin{array}{c}\text { Conser- } \\
\text { vative }(\mathrm{M})\end{array}$ & $\begin{array}{l}\text { “Best" Solubility } \\
\text { Concentration } \\
\text { Limit (M) }\end{array}$ & \\
\hline Cs & --- & --- & --- & --- & --- & --- & No solubility constraint is expected. \\
\hline $\mathrm{Ra}$ & $1 \times 10^{-5}$ & $3 \times 10^{-6}$ & $1 \times 10^{-5}$ & $3 \times 10^{-6}$ & $1 \times 10^{-5}$ & $3 \times 10^{-6}$ & $\begin{array}{l}\text { Ra sulfate is the controlling solid. Bayliss et al. } \\
\text { (4) found no precipitation for Ra at } 10^{-7} \mathrm{M} \text { in } \\
\text { concrete leachate. }\end{array}$ \\
\hline $\mathrm{Sr}$ & $2 \times 10^{-5}$ & $1 \times 10^{-7}$ & $2 \times 10^{-4}$ & $1 \times 10^{-6}$ & $5 \times 10^{-3}$ & $1 \times 10^{-3}$ & $\begin{array}{l}\text { Sr carbonate forms in cements }(1,2,3) \text { and could } \\
\text { be a plausible control in sediments also. }\end{array}$ \\
\hline $\begin{array}{l}\mathrm{Pb}, \mathrm{Pu} \\
\mathrm{Th}, \mathrm{Zr}\end{array}$ & $5 \times 10^{-7}$ & $1 \times 10^{-8}$ & $5 \times 10^{-7}$ & $1 \times 10^{-8}$ & $5 \times 10^{-6}$ & $1 \times 10^{-7}$ & $\begin{array}{l}\text { Assume hydroxide/hydrous oxides for } \mathrm{Th}, \mathrm{Zr}, \mathrm{Pu} \\
\text { and hydroxycarbonates for } \mathrm{Pb} \text {. There is data for } \\
\mathrm{Th} \text { and } \mathrm{Pu} \text { in cement leachates under oxidizing } \\
\text { and reducing conditions. We chose the oxidizing } \\
\text { conditions }(3) \text {. Other assessments of } \mathrm{Pb}, \mathrm{Pu}, \mathrm{Th} \\
\text { and/or } \mathrm{Zr} \text { solubility under these conditions have } \\
\text { been conducted }(1,2) \text {. }\end{array}$ \\
\hline $\mathrm{U}$ & $1 \times 10^{-6}$ & $1 \times 10^{-7}$ & $1 \times 10^{-6}$ & $1 \times 10^{-7}$ & $1 \times 10^{-5}$ & $1 \times 10^{-6}$ & $\begin{array}{l}\text { Two reports }(1,2) \text { discuss solubility in cements } \\
\text { using U(VI) hydrous oxide [schoepite] and } \\
\text { uranophane [calcium U(VI) silicate] as solubility } \\
\text { control. Ewart et al. (3) show some empirical } \\
\text { data for solubility in cement waters. Kaplan et al. } \\
(5) \text { reported } U-\mathrm{K}_{\mathrm{d}} \text { values increased from } \sim 2 \text { to } \\
>500 \mathrm{~mL} / \mathrm{g} \text { when the } \mathrm{pH} \text { of a Hanford sediment/ } \\
\text { groundwater slurry increased from } 8.3 \text { to }>10.5 \text {. } \\
\text { The extremely high } \mathrm{K}_{\mathrm{d}} \text { was attributed to U copre- } \\
\text { cipitation either as uranium phases or as calcite } \\
\text { phases. Serne et al. (6) discusses solubility of } \mathrm{U} \\
\text { in presence of groundwater. }\end{array}$ \\
\hline
\end{tabular}

(a) The aqueous and solid phases in this zone are greatly influenced by the presence of concrete. The concrete is assumed to age and form three distinct environment (Krupka and Serne 1998).

(b) References: 1 = Krupka and Serne (1998); 2 = Brady and Kozak (1995); 3 = Ewart et al. (1992); 4 = Bayliss et al. (1989); 5 = Kaplan et al. (1998a); 6 = Serne et al. (1999); 7 = Palmer (2000). 
Table 5.5. $\quad K_{d}$ Values for Zone $2 a-$ Chemically Impacted Far Field in Sand Sequence ${ }^{(a)}$

\begin{tabular}{|c|c|c|c|c|}
\hline Radionuclide & $\begin{array}{l}\text { Reasonable } \\
\text { Conservative } \\
\mathbf{K}_{\mathrm{d}}(\mathrm{mL} / \mathrm{g})\end{array}$ & $\begin{array}{c}\text { “Best” } K_{d} \\
(\mathrm{~mL} / \mathrm{g})\end{array}$ & $\begin{array}{c}\mathrm{K}_{\mathrm{d}} \text { Range } \\
(\mathrm{mL} / \mathrm{g})\end{array}$ & Justification/References $^{(\mathbf{b})}$ \\
\hline $\begin{array}{l}{ }^{3} \mathrm{H}, \mathrm{Cl}, \mathrm{N} \text { as } \\
\text { nitrate, } \mathrm{Cr} \text { as } \\
\text { chromate, } \mathrm{Tc}, \mathrm{Nb}\end{array}$ & 0 & 0 & 0 to 0.1 & $\begin{array}{l}\mathrm{Tc} \text {, chromate, nitrate and } \mathrm{Cl} \text { are anionic and under slightly alkaline conditions formed by glass or cement } \\
\text { leachates Hanford sediments show very little tendency to adsorb anions. }{ }^{3} \mathrm{H} \text { will move with } \mathrm{H}_{2} \mathrm{O} \text {. Limited } \\
\text { information available for geochemical behavior of } \mathrm{Nb} \text {. Nb expected to be anionic at } \mathrm{pH}>7 \text {; see discussion in } \\
\text { Robertson et al. (19). }\end{array}$ \\
\hline $\begin{array}{l}\mathrm{Ac}, \mathrm{Am}, \mathrm{Ce}, \mathrm{Cm}, \\
\mathrm{Eu}\end{array}$ & 100 & 350 & 100 to 1,500 & Am- $\mathrm{K}_{\mathrm{d}}$ values: In low-ionic-strength Ca system, $>1200 \mathrm{~mL} / \mathrm{g}$; in low-ionic-strength Na system, $280 \mathrm{~mL} / \mathrm{g}$ (1) \\
\hline $\mathrm{C}$ & 5 & 20 & 5 to 50 & $\begin{array}{l}\text { Estimated. }{ }^{14} \mathrm{C} \text { geochemistry complex and poorly described by } \mathrm{K}_{\mathrm{d}} \text { construct. }{ }^{14} \mathrm{C} \text { is expected to enter liquid, } \\
\text { solid and gas phase through volatilization }\left(\mathrm{CO}_{2} \text {-gas), precipitation with calcite, isotopic exchange, and }\right. \\
\text { adsorption. Based on Martin (9), who measured }{ }^{14} \mathrm{C}-\mathrm{K}_{\mathrm{d}} \text { values in Hanford sediments using uncontaminated } \\
\text { Hanford groundwater (relatively low ionic strength). }{ }^{14} \mathrm{C}^{14} \mathrm{H}^{14} \mathrm{CO}_{3} \mathrm{~K}_{\mathrm{d}} \text { values increased during a } 70 \text { day contact } \\
\text { time from } 0 \text { (1-hr contact time) to } 400 \mathrm{~mL} / \mathrm{g} \text { in sediment and } 20\left(1 \text {-hr contact time) to } 360 \mathrm{~mL} / \mathrm{g} \text { in calcrete. }{ }^{14} \mathrm{C}\right. \\
\text { removed by solid phases never stabilized during } 70 \text { days, suggesting coprecipitation reaction. }\end{array}$ \\
\hline Co & 150 & 300 & 150 to 2,000 & $\begin{array}{l}\text { In } 0.01 \text { to } 1 \mathrm{M} \mathrm{Na} \text { system, } \mathrm{K}_{\mathrm{d}} \text { is } 1060 \text { to } 4760 \mathrm{~mL} / \mathrm{g}(2) \\
\text { In } 0.01 \text { to } 1 \mathrm{M} \text { Ca system, } \mathrm{K}_{\mathrm{d}} \text { is } 222 \text { to } 640 \mathrm{~mL} / \mathrm{g}(2) \\
\text { Forms complexes, especially with organics. }\end{array}$ \\
\hline Cs & 40 & 80 & 40 to 2,000 & $\begin{array}{l}\text { Estimated. In low-ionic-strength Na system, } \mathrm{K}_{\mathrm{d}} \text { is } 64 \text { to } 1,170 \mathrm{~mL} / \mathrm{g}(2) \text {. No complexes. } \\
\text { In low-ionic-strength Ca system, } \mathrm{K}_{\mathrm{d}} \text { is } 790 \text { to } 1360 \mathrm{~mL} / \mathrm{g}(2) \text {. } \\
\text { Unpublished recent results from Zachara (PNNL, EMSP project) using Hanford sediments and simulated tank } \\
\text { waste indicate that Cs sorption decreases markedly compared to when ionic strength is appreciably lower. }\end{array}$ \\
\hline I & 0 & 0.1 & 0 to 0.2 & $\begin{array}{l}\text { Anion. Um and Serne (15) show low but non-zero } K_{\mathrm{d}} \text { values that range between } 0.04 \text { and } 0.16 \text { for synthetic } \\
\text { glass leachate contacting a typical IDF borehole sand. Even with additional dilution with native pore waters the } \\
\text { pH will be higher than ambient in Zone } 2 \text { so the glass leachate values will be used for Zone } 2 \text { also. }\end{array}$ \\
\hline $\mathrm{Ni}, \mathrm{Sn}$ & 40 & 80 & 40 to 400 & $\mathrm{Ni}$ is similar to Co but adsorbs slightly less possibly because of moderate complexing. Estimated $(3,4)$ \\
\hline $\mathrm{Np}, \mathrm{Pa}$ & 0.2 & 0.8 & 0.2 to 5 & $\begin{array}{l}\mathrm{Np} \mathrm{K}_{\mathrm{d}} \text { values in low-ionic-strength solutions }=0.4 \text { to } 4 \mathrm{~mL} / \mathrm{g}(1) \text {. The dominant protactinium species is assumed } \\
\text { to be } \mathrm{PaO}_{2}^{+} \text {. NpO }{ }_{2}^{+} \text {is assumed to be a reasonable analog }(10) \text {. Based on studies conducted at the Whiteshell } \\
\text { Laboratories (personal communications with T. T. (Chuck) Vandergraaf, Atomic Energy of Canada Limited, } \\
\text { Pinawa, Manitoba, Canada), Pa sorbs appreciably more than Np. Thus, Pa- } \mathrm{K}_{\mathrm{d}} \text { estimates based on measured Np- } \\
\mathrm{K}_{\mathrm{d}} \text { values will be conservative. }\end{array}$ \\
\hline $\mathrm{Pb}$ & 20 & 100 & 20 to 1,000 & Good absorber, insoluble. Estimated (4). \\
\hline $\mathrm{Pu}$ & 80 & 200 & 80 to 1,000 & $\mathrm{~K}_{\mathrm{d}}$ is $>98 \mathrm{~mL} / \mathrm{g}(5)$ \\
\hline
\end{tabular}


Table 5.5 (contd)

\begin{tabular}{|c|c|c|c|c|c|}
\hline \multicolumn{2}{|c|}{ Radionuclide } & $\begin{array}{c}\text { Reasonable } \\
\text { Conservative } \\
\mathbf{K}_{\mathrm{d}}(\mathrm{mL} / \mathbf{g})\end{array}$ & $\begin{array}{c}\text { "Best” } K_{d} \\
(\mathrm{~mL} / \mathrm{g})\end{array}$ & $\begin{array}{c}\mathrm{K}_{\mathrm{d}} \text { Range } \\
(\mathrm{mL} / \mathrm{g})\end{array}$ & Justification/References $^{(\mathbf{b})}$ \\
\hline \multicolumn{2}{|c|}{$\mathrm{Ra}, \mathrm{Sr}$} & 0.2 & 10 & 0.2 to 50 & $\begin{array}{l}\text { Na system, } 1.7 \text { to } 42 \mathrm{~mL} / \mathrm{g} \text { for Sr- } \mathrm{K}_{\mathrm{d}}(2) \text {. Ca system, } 0.3 \text { to } 1.6 \mathrm{~mL} / \mathrm{g} \text { for Sr- } \mathrm{K}_{\mathrm{d}}(2) \text {. In } 4 \mathrm{M} \mathrm{NaNO}_{3} \text {, Sr- } \mathrm{K}_{\mathrm{d}} \text { in } \\
\text { Hanford sediment was } 5 \mathrm{~mL} / \mathrm{g}(\mathrm{pH} 8) \text {, and } 10 \mathrm{~mL} / \mathrm{g} \text { (pH } 10)(12) \text {. Near identical } \mathrm{K}_{\mathrm{d}} \text { values using Savannah } \\
\text { River Site Sediments and } 30 \% \mathrm{NaNO}_{3}(13) \text {. Based on periodicity considerations, Ra would be expected to sorb } \\
\text { more strongly to sediments than } \mathrm{Sr} \text {, but no Hanford Ra- } \mathrm{K}_{\mathrm{d}} \text { values are available. Thus, basing Ra- } \mathrm{K}_{\mathrm{d}} \text { estimates } \\
\text { on measured Sr- } \mathrm{K}_{\mathrm{d}} \text { values will likely provide a conservative Ra- } \mathrm{K}_{\mathrm{d}} \text { estimate. }\end{array}$ \\
\hline \multicolumn{2}{|l|}{$\mathrm{Ru}$} & 0 & 1 & 0 to 500 & May form $\mathrm{RuO}_{4}{ }^{2-}$ and/or anionic complexes with nitrates and nitrites. Estimate $(3,6,7)$. \\
\hline \multicolumn{2}{|l|}{$\mathrm{Se}$} & 1 & 2 & 0 to 10 & $\begin{array}{l}\text { Anionic. Se } \mathrm{K}_{\mathrm{d}} \text { measured at the ILAW/IDF site had } \mathrm{K}_{\mathrm{d}} \text { values of } 6.7 \pm 0.4 \mathrm{~mL} / \mathrm{g}(14) \text {. Results of a Se sorption } \\
\text { experiment to Hanford sediments in high ionic strength }\left(\mathrm{NaOH} \text { and } \mathrm{NaOCl}_{4} \text { ) indicate } \mathrm{Se} \mathrm{K}_{\mathrm{d}} \text { values range from } 0\right. \\
\text { to } 18 \mathrm{~mL} / \mathrm{g} \text {; but values for } 0.03 \mathrm{NaOH} \text { are } 0 \mathrm{~mL} / \mathrm{g} \text { and are beyond the causticity of probable glass leachates }(16) \text { ). } \\
\mathrm{K}_{\mathrm{d}} \text { values will be chosen from recent tests on IDF borehole sediments with synthetic glass leachate that yielded } \\
\mathrm{K}_{\mathrm{d}} \text { values which ranged from } 1 \text { to } 3 \mathrm{~mL} / \mathrm{g}(15) \text {. }\end{array}$ \\
\hline \multicolumn{2}{|c|}{ Th, Zr } & 40 & 300 & 40 to 500 & Sandy soil data, $\mathrm{K}_{\mathrm{d}}$ is 40 to $470 \mathrm{~mL} / \mathrm{g}$ for $\mathrm{Th}(8)$. \\
\hline \multicolumn{2}{|l|}{$\mathrm{U}$} & 0.05 & 0.2 & 0 to 500 & $\begin{array}{l}\text { See section } 6 \text { for details that rely on Serne et al. } 2002 \mathrm{a}(17) \text {. Earlier data by Kaplan et al. (11) reported U(VI) } \mathrm{K}_{\mathrm{d}} \\
\text { values increased from } \sim 2 \text { to }>500 \mathrm{~mL} / \mathrm{g} \text { when the } \mathrm{pH} \text { of a Hanford sediment/groundwater slurry increased from } \\
8.3 \text { to }>10.5 \text {. The extremely high } \mathrm{K}_{\mathrm{d}} \text { was attributed to } \mathrm{U} \text { coprecipitation either as uranium phases or as calcite } \\
\text { phases. But these data are not relevant for glass leachates that do not contain adequate Ca to allow calcite } \\
\text { precipitation that removes carbonate/bicarbonate anions that keep } \mathrm{U}(\mathrm{VI}) \text { highly soluble and resistant to } \\
\text { adsorption at slightly alkaline } \mathrm{pH} \text { values. Glass leachates are projected to be } \mathrm{pH} \sim 9 \text { to } 9.5 \text { with } \sim 0.034 \mathrm{M} \\
\text { inorganic carbon mostly as bicarbonate }(18) \text { that will complex dissolved } \mathrm{U}(\mathrm{VI}) \text { lowering the } \mathrm{K}_{\mathrm{d}} \text { to values well } \\
\text { below those reported in (11). For now assume that glass leachate in dominated by sodium bicarbonate/carbonate } \\
\text { solution that allows anionic } \mathrm{U}(\mathrm{VI}) \text { carbonate species to predominate and sorption to be very low. }\end{array}$ \\
\hline \multicolumn{6}{|c|}{$\begin{array}{l}\text { (a) The aqueous phase is moderately altered from the cement and glass leachate emanating from zones } 1 \text { and } 2 ; \mathrm{pH} \text { is between } 8 \text { (background) and } 11 \text {, and the ionic strength is } \\
\text { between } 0.01 \text { (background) and 0.1. The solid phase is in the sand-dominated sequence and is slightly altered due to contact with the moderately caustic aqueous phase } \\
\text { (Table } 4.3 \text { and Figure 4.3). } \\
\text { (b) References: } 1=\text { Routson et al. (1976); } 2=\text { Routson et al. (1978); } 3=\text { Ames and Serne }(1991) ; 4=\text { Kaplan et al. }(1995) ; 5=\text { Rhodes }(1957 \mathrm{a}, \mathrm{b}) ; 6=\text { Ames and Rai }(1978) ; 7 \\
\text { = Barney (1978); } 8=\text { Sheppard et al. }(1976) ; 9=\text { Martin }(1996) ; 10=\text { Pourbaix }(1966) ; 11=\text { Kaplan et al. (1998a); } 12=\text { Rhodes and Nelson }(1957) ; 13=\text { Prout }(1959) ; 14= \\
\text { Kaplan et al. (1998c); } 15=\text { Um and Serne (2004, in review); } 16=\text { Kaplan et al. (2003); } 17=\text { Serne et al. (2002a); } 18=\text { STORM code predictions of the long-term steady } \\
\text { state glass leachate composition - - see Section } 6.0 \text { for more discussion; } 19=\text { Robertson et al. (2003). }\end{array}$} \\
\hline
\end{tabular}


Table 5.6. $K_{d}$ Values for Zone $2 b$ - Far Field in Sand Sequence with Natural Recharge (no impact from wastes) ${ }^{(a)}$

\begin{tabular}{|c|c|c|c|c|}
\hline Radionuclide & $\begin{array}{c}\text { Reasonably } \\
\text { Conservative } \\
\mathbf{K}_{\mathrm{d}}(\mathrm{mL} / \mathrm{g})\end{array}$ & $\begin{array}{l}\text { “Best” } K_{d} \\
(\mathbf{m L} / \mathrm{g})\end{array}$ & $\begin{array}{c}\mathbf{K}_{\mathrm{d}} \text { Range } \\
(\mathrm{mL} / \mathrm{g})\end{array}$ & Justification/References $^{(\mathbf{b})}$ \\
\hline $\begin{array}{l}{ }^{3} \mathrm{H}, \mathrm{Cl}, \mathrm{Tc}, \mathrm{N} \\
\text { as nitrate, } \\
\mathrm{Cr}(\mathrm{VI}) \text { as } \\
\text { chromate, } \mathrm{Nb}\end{array}$ & 0 & 0 & 0 to 0.6 & $\begin{array}{l}\text { Tc exists predominantly as } \mathrm{TcO}_{4}^{-} \text {. A review of Hanford sediment Tc- } \mathrm{K}_{\mathrm{d}} \text { values showed a range of }-2.8 \text { to } 0.6 \mathrm{~mL} / \mathrm{g} \\
\text { for } 15 \text { observations; median was } 0.1 \mathrm{~mL} / \mathrm{g}(1) \text {. Later studies did not change this range but did decrease the median } \\
\text { slightly to -0.1 mL/g (2). Negative } \mathrm{K}_{\mathrm{d}} \text { values are physically possible and may not be an experimental artifact }(2){ }^{3} \mathrm{H} \\
\text { is expected to move along with water. Cl and nitrate are expected to behave as a dissolved anionic species. Most } \\
\text { recent results using ILAW specific borehole sediments [299-E17-21 and } 299-\mathrm{E} 21-24] \text { yielded Tc-K } \mathrm{K}_{\mathrm{d}} \text { of } 0 \mathrm{~mL} / \mathrm{g} \text {. See } \\
\text { (18) and (19) for details. (21) lists } \mathrm{K}_{\mathrm{d}} \text { values for } \mathrm{Cr}(\mathrm{VI}) \text {, nitrate, and Tc in Tables } 10,12 \text {, and } 15 \text {, respectively that } \\
\text { give ranges of } 0 \text { to } 1,0 \text { (all ground-water values), and } 0 \text { to } 0.1 \mathrm{~mL} / \mathrm{g} \text {, respectively. These ranges are used in } \mathrm{SAC} \text { to } \\
\text { perform stochastic predictions for contaminant transport in natural Hanford groundwater/aquifer predictions. Limited } \\
\text { information available for geochemical behavior of Nb. Nb expected to be anionic at } \mathrm{pH}>7 \text {; see discussion in } \\
\text { Robertson et al. (22). }\end{array}$ \\
\hline $\begin{array}{l}\mathrm{Ac}, \mathrm{Am}, \mathrm{Ce} \\
\mathrm{Cm}, \mathrm{Eu}\end{array}$ & 60 & 300 & 60 to 1,300 & Am- $\mathrm{K}_{\mathrm{d}}: 67$ to $>1,200 \mathrm{~mL} / \mathrm{g}(3)$. Am- $\mathrm{K}_{\mathrm{d}}: 125$ to $833 \mathrm{~mL} / \mathrm{g}(4)$ \\
\hline $\mathrm{C}$ & 0.5 & 5 & 0.5 to 1,000 & $\begin{array}{l}\text { Assumed dominant species: } \mathrm{HCO}_{3}^{-} \text {. Three processes will be acting on the }{ }^{14} \mathrm{C} \text { to take it out of solution: adsorption } \\
\text { onto the calcite surface, volatilization as } \mathrm{CO}_{2} \text { gas, and precipitation into the calcite structure. The latter process is } \\
\text { largely irreversible; therefore, it is not well represented by the } \mathrm{K}_{\mathrm{d}} \text { construct }\left(\mathrm{K}_{\mathrm{d}} \text { assumes that adsorption occurs as }\right. \\
\text { readily as desorption). Volatilization is entirely removed from the definition of the } \mathrm{K}_{\mathrm{d}} \text { construct. In systems that } \\
\text { contain higher concentrations of carbonate minerals, such as the calcrete layer in the } 200 \text { West Area, an appreciably } \\
\text { higher } \mathrm{K}_{\mathrm{d}} \text { should be used to account for the isotopic dilution/precipitation reaction that may occur. A } \mathrm{K}_{\mathrm{d}} \text { of } 100 \mathrm{~mL} / \mathrm{g} \\
\text { would be appropriate for such a system. Since most of the } 100 \text { and } 200 \text { plateau areas contain }<1 \% \text { carbonate, lower } \\
\mathrm{K}_{\mathrm{d}} \text { values are warranted for these areas, such as } 0.5 \mathrm{~mL} / \mathrm{g} \text {. } \mathrm{K}_{\mathrm{d}} \text { values of }{ }^{14} \mathrm{C} \text { of }>250 \mathrm{~mL} / \mathrm{g} \text { have been measured in } \\
\text { calcite (5). At } 100 \mathrm{~K} \text {, the C-14 is widely distributed down gradient from a major source (crib) associated with reactor } \\
\text { operations. (Additional references: } 6,7,8,9,10) \text {. Estimated range. }\end{array}$ \\
\hline Co & 1,000 & 2,000 & $\begin{array}{l}1,000 \text { to } \\
12,500\end{array}$ & $\begin{array}{l}\text { Na system, } 1,290 \text { to } 2,120 \mathrm{~mL} / \mathrm{g}(11) \\
\text { Ca system, } 2,000 \text { to } 3,870 \mathrm{~mL} / \mathrm{g}(11) \\
\text { Hanford sediment/groundwater system } 11,600 \text { to } 12,500 \mathrm{~mL} / \mathrm{g}(12)\end{array}$ \\
\hline Cs & 500 & 2,000 & 500 to 4,000 & $\begin{array}{l}\text { Na system, }, 1410 \text { to } 1,590 \mathrm{~mL} / \mathrm{g}(11) \\
\text { Hanford sediment/groundwater system, } 540 \text { to } 3,180 \mathrm{~mL} / \mathrm{g}(12) \text {. Most recent results using ILAW specific borehole } \\
\text { sediments (299-E17-21) yielded } \mathrm{K}_{\mathrm{d}} \text { of 2,030 597. See Kaplan et al. (18) for details. }\end{array}$ \\
\hline
\end{tabular}


Table 5.6. (contd)

\begin{tabular}{|c|c|c|c|c|}
\hline Radionuclide & $\begin{array}{c}\text { Reasonably } \\
\text { Conservative } \\
\mathbf{K}_{\mathbf{d}}(\mathbf{m L} / \mathbf{g})\end{array}$ & $\begin{array}{l}\text { “Best” } \mathbf{K}_{\mathrm{d}} \\
(\mathrm{mL} / \mathrm{g})\end{array}$ & $\begin{array}{c}\mathbf{K}_{\mathrm{d}} \text { Range } \\
(\mathrm{mL} / \mathrm{g})\end{array}$ & Justification/References $^{(\mathbf{b})}$ \\
\hline I & 0 & 0.25 & 0.0 to 15 & $\begin{array}{l}\text { A review of Hanford sediment I- } \mathrm{K}_{\mathrm{d}} \text { values showed a range of } 0.7 \text { to } 15 \mathrm{~mL} / \mathrm{g} \text { for } 9 \text { observations; median was } \\
0.7 \mathrm{~mL} / \mathrm{g} \text { (1). Later studies increased this range to } 0.2 \text { to } 15 \mathrm{~mL} / \mathrm{g} \text {; the median was decreased to } 0.3 \mathrm{~mL} / \mathrm{g}(2) \text {. } \\
\text { Results using ILAW specific borehole sediments }(299-\mathrm{E} 17-21) \text { yielded } \mathrm{K}_{\mathrm{d}} \text { of } 0 \mathrm{~mL} / \mathrm{g}(18) \text {, but more recent results by } \\
\text { Um et al. (19) for ILAW borehole } 299 \text {-E24-21 show non-zero } \mathrm{K}_{\mathrm{d}} \text { with an average value of } 0.2 \text { to } 0.3 \mathrm{~mL} / \mathrm{g} \text { for far- } \\
\text { field. (21) recommends a range of } 0 \text { to } 2 \mathrm{~mL} / \mathrm{g} \text { for general Hanford transport conditions performed by SAC. }\end{array}$ \\
\hline $\mathrm{Ni}, \mathrm{Sn}$ & 50 & 300 & 50 to 2,500 & $\begin{array}{l}\text { Ni: Hanford sediment/groundwater system, } 440 \text { to } 2,350 \mathrm{~mL} / \mathrm{g}(12) \text {. A study of a broad range of sediments, } \\
\text { including those from Hanford, had Ni-K } \mathrm{K}_{\mathrm{d}} \text { values of } 50-340 \mathrm{~mL} / \mathrm{g}(13) \text {. }\end{array}$ \\
\hline $\mathrm{Np}$ & 2 & 15 & 2 to 25 & $\begin{array}{l}\text { A review of Hanford sediment Np- } \mathrm{K}_{\mathrm{d}} \text { values showed range of } 2.4 \text { to } 21.7 \mathrm{~mL} / \mathrm{g} \text { for four observations; median was } \\
17.8 \mathrm{~mL} / \mathrm{g}(1) \text {. Later studies increased the slightly to } 2.2 \text { to } 21.7 \mathrm{~mL} / \mathrm{g} \text {; the median was slightly lowered, } 15 \mathrm{~mL} / \mathrm{g} \\
\text { (2). (21) recommends a range of } 2 \text { to } 30 \mathrm{~mL} / \mathrm{g} \text { for SAC stochastic transport predictions. This range is nearly } \\
\text { identical to our chosen range for deterministic IDF predictions. }\end{array}$ \\
\hline $\mathrm{Pb}$ & 8,000 & 10,000 & $\begin{array}{l}8,000 \text { to } \\
80,000\end{array}$ & pH 6 and no competing ions: 13,000 to $79,000 \mathrm{~mL} / \mathrm{g}(14)$ \\
\hline $\mathrm{Pu}$ & 50 & 150 & 50 to 2,000 & $\mathrm{Pu}(\mathrm{V}, \mathrm{VI}): \mathrm{pH} 4$ to $12: 80$ to $>1,980 \mathrm{~mL} / \mathrm{g}(15)$ \\
\hline $\mathrm{Ra}, \mathrm{Sr}$ & 5 & 14 & 5 to 200 & $\begin{array}{l}\text { Sr K } \mathrm{d}_{\mathrm{d}} \text { values: } \\
\text { Na system, } 173 \mathrm{~mL} / \mathrm{g}, 49 \text { to } 50 \mathrm{~mL} / \mathrm{g}(11) \\
\text { Ca system, } 8 \text { to } 13 \mathrm{~mL} / \mathrm{g}, 5 \text { to } 19 \mathrm{~mL} / \mathrm{g}(11) \\
5 \text { to } 120 \mathrm{~mL} / \mathrm{g}(15) \\
19.1 \text { to } 21.5 \mathrm{~mL} / \mathrm{g}(12) \\
\text { Na system, } \mathrm{pH} 7 \text { to } 11,14.9 \text { to } 25.1 \mathrm{~mL} / \mathrm{g}(16) \\
\text { Data using ILAW borehole sediment [299-E17-21] yielded } 14.3 \pm 1.6 \text {. See (18). Most recent data using ILAW } \\
\text { borehole sediment from } 299-\mathrm{E} 24-21 \text { showed } \mathrm{Sr} \mathrm{K}_{\mathrm{d}} \text { was } 14.6 \pm 1.1 \mathrm{~mL} / \mathrm{g} \text { in excellent agreement with (18). }\end{array}$ \\
\hline $\mathrm{Ru}$ & 10 & 20 & 10 to 1,000 & Estimated (17 as cited in 11) \\
\hline $\mathrm{Se}$ & 3 & 7 & 3 to 15 & $\begin{array}{l}\text { Hanford groundwater/sediment system: }-3.44 \text { to } 0.78 \mathrm{~mL} / \mathrm{g}(12) \text {. Most recent data using ILAW borehole sediment } \\
\text { [299-E17-21] yielded } \mathrm{K}_{\mathrm{d}} \text { values ranging from } 3.75 \text { to } 10.85 \mathrm{~mL} / \mathrm{g} \text { and had an average of } 6.7 \pm 1.9 \mathrm{~mL} / \mathrm{g}(18) \text {. More } \\
\text { recent data for ILAW borehole } 299-\mathrm{E} 24-21 \text { yielded a } \mathrm{K}_{\mathrm{d}} \text { range from } 7.1 \text { to } 8.65 \text { for } 6 \text { measurements in Hanford } \\
\text { groundwater. [19]. The latter two studies are in excellent agreement. Cantrell et al. } 2003 \text { [21] recommends a range } \\
\text { of } 0 \text { to } 3 \text { and } 3 \text { to } 10 \mathrm{~mL} / \mathrm{g} \text { for Se for "higher" and "low/trace" concentrations of Se for SAC stochastic predictions. } \\
\text { Our range is slightly larger but the best and reasonable conservative values we recommend for the IDF deterministic } \\
\text { PA activities fit within the range chosen for trace concentrations of Se. }\end{array}$ \\
\hline $\mathrm{Th}, \mathrm{Zr}$ & 40 & 1,000 & 40 to 2,500 & $\begin{array}{l}\text { Estimated. } \\
\text { Zr: pH } 6 \text { to } 12: 90 \text { to }>2,000 \mathrm{~mL} / \mathrm{g}(15)\end{array}$ \\
\hline
\end{tabular}


Table 5.6. (contd)

\begin{tabular}{|c|c|c|c|c|}
\hline Radionuclide & $\begin{array}{c}\text { Reasonably } \\
\text { Conservative } \\
\mathbf{K}_{\mathbf{d}}(\mathrm{mL} / \mathrm{g})\end{array}$ & $\begin{array}{c}\text { “Best” } K_{d} \\
(\mathrm{~mL} / \mathrm{g})\end{array}$ & $\begin{array}{c}\mathrm{K}_{\mathrm{d}} \text { Range } \\
(\mathrm{mL} / \mathrm{g})\end{array}$ & Justification/References $^{(\mathbf{b})}$ \\
\hline $\mathrm{U}$ & 0.2 & 1 & 0.1 to 4 & $\begin{array}{l}\text { A review of Hanford sediment } \mathrm{U}-\mathrm{K}_{\mathrm{d}} \text { values showed range of } 0.1 \text { to } 79.3 \mathrm{~mL} / \mathrm{g} \text { for } 13 \text { observations; median was } 0.6 \\
\mathrm{~mL} / \mathrm{g}(1) \text {. Results from later studies support the range (2). In all reported data, some U was adsorbed by Hanford } \\
\text { sediments and }>90 \% \text { of the values were between } 0.6 \text { and } 4 \mathrm{~mL} / \mathrm{g} \text {. Most recent work with the ILAW Borehole } \\
\text { sediment }[299-\mathrm{E} 17-21] \text { yielded } \mathrm{K}_{\mathrm{d}} \text { of } 0.6 \pm 0.1 \text {. See }(18) \text {. An extensive new data set for sediments from the } 300 \text { Area } \\
\text { that studied the } \mathrm{K}_{\mathrm{d}} \text { for U(VI) as a function of } \mathrm{pH} \text { and carbonate concentration found values that ranged from } \sim 0 \text { to } 7 \\
\mathrm{~mL} / \mathrm{g}(20) \text {; but for typical groundwater conditions the range narrows to } 0.2 \text { to } 4 \mathrm{~mL} / \mathrm{g} \text { as reviewed and critically } \\
\text { evaluated by Cantrell et al. (21). The "reasonable conservative" and "best" } \mathrm{K}_{\mathrm{d}} \text { values chosen for the IDF activities } \\
\text { fall within Cantrell et al.'s narrow range of recommended } \mathrm{U} \text { values. }\end{array}$ \\
\hline \multicolumn{5}{|c|}{ 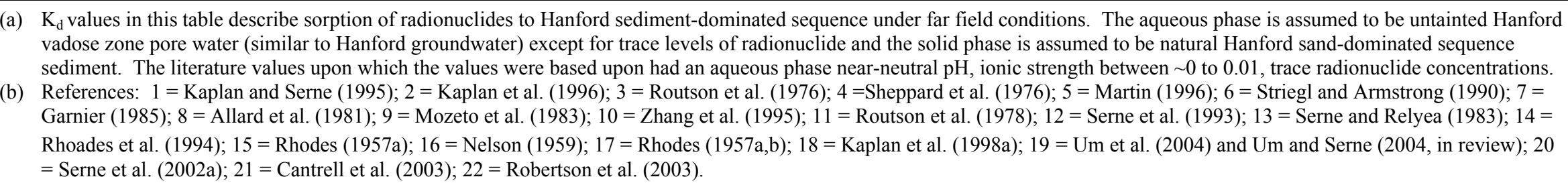 } \\
\hline
\end{tabular}


Table 5.7. Gravel-Corrected $K_{d}$ Values $\left(K_{d g c}\right)$ for Zone 3a - Chemically Impacted Far Field in Gravel Sequence ${ }^{(a)}$

\begin{tabular}{|c|c|c|c|c|}
\hline Radionuclide & $\begin{array}{l}\text { Reasonable } \\
\text { Conservative } \\
\mathrm{K}_{\mathrm{dgc}}(\mathrm{mL} / \mathrm{g})\end{array}$ & $\begin{array}{c}\text { "Best" } \\
\mathbf{K}_{\mathrm{dgc}} \\
(\mathrm{mL} / \mathrm{g})\end{array}$ & $\begin{array}{c}\mathbf{K}_{\mathrm{dgc}} \text { Range } \\
(\mathrm{mL} / \mathrm{g})\end{array}$ & Justification/References $^{(\mathbf{b})}$ \\
\hline $\begin{array}{l}{ }^{3} \mathrm{H}, \mathrm{Cl}, \mathrm{N} \text { as } \\
\text { nitrate, } \mathrm{Cr} \text { as } \\
\text { chromate, } \mathrm{Tc} \text {, } \\
\mathrm{Nb}\end{array}$ & 0 & 0 & 0 to 0.01 & $\begin{array}{l}\text { No gravel-corrected } \mathrm{K}_{\mathrm{d}} \text { data available. Tc, nitrate, chromate and } \mathrm{Cl} \text { are anionic. }{ }^{3} \mathrm{H} \text { will move with } \mathrm{H}_{2} \mathrm{O} \text {. Limited } \\
\text { information available for geochemical behavior of } \mathrm{Nb} \text {. Nb expected to be anionic at } \mathrm{pH}>7 \text {; see discussion in Robertson } \\
\text { et al. (18). }\end{array}$ \\
\hline $\begin{array}{l}\mathrm{Ac}, \mathrm{Am}, \mathrm{Ce} \\
\mathrm{Cm}, \mathrm{Eu}\end{array}$ & 10 & 35 & 10 to 150 & $\begin{array}{l}\text { No gravel-corrected } \mathrm{K}_{\mathrm{d}} \text { data available. Am-K } \mathrm{K}_{\mathrm{d}} \text { values: In low-ionic-strength Ca system, }>1,200 \mathrm{~mL} / \mathrm{g} \text {; in low-ionic-strength } \\
\text { Na system, } 280 \mathrm{~mL} / \mathrm{g}(1)\end{array}$ \\
\hline $\mathrm{C}$ & 0.5 & 2 & 0.5 to 5 & $\begin{array}{l}\text { Estimated. No gravel-corrected } \mathrm{K}_{\mathrm{d}} \text { data available. }{ }^{14} \mathrm{C} \text { geochemistry complex and poorly described by } \mathrm{K}_{\mathrm{d}} \text { construct. }{ }^{14} \mathrm{C} \text { is } \\
\text { expected to enter liquid, solid and gas phase through volatilization }\left(\mathrm{CO}_{2} \text {-gas), precipitation with calcite, isotopic exchange, }\right. \\
\text { and adsorption. Based on Martin }(9) \text {, who measured }{ }^{14} \mathrm{C}-\mathrm{K}_{\mathrm{d}} \text { values in Hanford sediments using uncontaminated Hanford } \\
\text { groundwater (relatively low ionic strength). } \mathrm{K}_{\mathrm{d}} \text { values increased during a } 70 \text { day contact time from } 0 \text { (1-hr contact time) to } \\
400 \mathrm{~mL} / \mathrm{g} \text { in sediment and } 20\left(1 \text {-hr contact time) to } 360 \mathrm{~mL} / \mathrm{g} \text { in calcrete. }{ }^{14} \mathrm{C} \text { removed by solid phases never stabilized }\right. \\
\text { during } 70 \text { days, suggesting coprecipitation reaction. }\end{array}$ \\
\hline Co & 15 & 30 & 15 to 200 & $\begin{array}{l}\text { No gravel-corrected } \mathrm{K}_{\mathrm{d}} \text { data available. } \\
\text { In low-ionic-strength } \mathrm{Na} \text { system, } 1060 \text { to } 4760 \mathrm{~mL} / \mathrm{g}(2) \\
\text { In low-ionic-strength Ca system, } 222 \text { to } 640 \mathrm{~mL} / \mathrm{g}(2) \\
\text { Forms complexes, especially with organics. }\end{array}$ \\
\hline Cs & 4 & 8 & 4 to 200 & $\begin{array}{l}\text { No gravel-corrected } \mathrm{K}_{\mathrm{d}} \text { data available. No complexes. } \\
\text { Estimated. In } 0.01 \text { to } 0.1 \mathrm{M} \text { Na system, } 64 \text { to } 1170 \mathrm{~mL} / \mathrm{g}(2) \text {. } \\
\text { In } 0.01 \text { to } 0.1 \mathrm{M} \text { Ca system, } 790 \text { to } 1,360 \mathrm{~mL} / \mathrm{g}(2) \text {. } \\
\text { Unpublished recent results from Zachara (PNNL, EMSP project) using Hanford sediments and simulated tank waste indicate } \\
\text { that Cs sorption decreases markedly compared to when ionic strength is appreciably lower. }\end{array}$ \\
\hline I & 0 & 0 & 0 to 0.02 & No gravel-corrected $\mathrm{K}_{\mathrm{d}}$ data available. Anion. Estimated. \\
\hline $\mathrm{Ni}, \mathrm{Sn}$ & 4 & 8 & 4 to 40 & $\mathrm{Ni}$ is similar to Co but adsorbs slightly less possibly because of moderate complexing. Estimated $(3,4)$ \\
\hline $\mathrm{Np}, \mathrm{Pa}$ & 0.02 & 0.08 & 0.04 to 0.5 & $\begin{array}{l}\text { No gravel-corrected } \mathrm{K}_{\mathrm{d}} \text { data available. } \mathrm{Np} \mathrm{K}_{\mathrm{d}} \text { values in low-ionic-strength solutions }=0.4 \text { to } 4 \mathrm{~mL} / \mathrm{g}(1) \text {. The dominant } \\
\text { protactinium species is assumed to be } \mathrm{PaO}_{2}{ }^{+} . \mathrm{NpO}_{2}{ }^{+} \text {is assumed to be a reasonable analog }(10) \text {. Based on studies conducted } \\
\text { at the Whiteshell Laboratories (personal communication with T. T. (Chuck) Vandergraaf, Atomic Energy of Canada Limited, } \\
\text { Pinawa, Manitoba, Canada), Pa sorbs appreciably more than Np. Thus, Pa- } \mathrm{K}_{\mathrm{d}} \text { estimates based on measured Np- } \mathrm{K}_{\mathrm{d}} \text { values } \\
\text { will be conservative. }\end{array}$ \\
\hline $\mathrm{Pb}$ & 2 & 10 & 2 to 100 & No gravel-corrected $K_{d}$ data available. Good absorber, insoluble. Estimated (4). \\
\hline $\mathrm{Pu}$ & 8 & 20 & 8 to 100 & No gravel-corrected $\mathrm{K}_{\mathrm{d}}$ data available. $>98 \mathrm{~mL} / \mathrm{g}(5)$ \\
\hline
\end{tabular}


Table 5.7. (contd)

\begin{tabular}{|c|c|c|c|c|}
\hline Radionuclide & $\begin{array}{l}\text { Reasonable } \\
\text { Conservative } \\
\mathrm{K}_{\mathrm{dgc}}(\mathrm{mL} / \mathrm{g})\end{array}$ & $\begin{array}{c}\text { "Best” } \\
\mathbf{K}_{\mathrm{dgc}} \\
(\mathbf{m L} / \mathrm{g})\end{array}$ & $\begin{array}{c}\mathrm{K}_{\mathrm{dgc}} \text { Range } \\
(\mathrm{mL} / \mathrm{g})\end{array}$ & Justification/References $^{(\mathbf{b})}$ \\
\hline $\mathrm{Ra}, \mathrm{Sr}$ & 0.02 & 1 & 0.02 to 5 & $\begin{array}{l}\text { Na system, } 1.7 \text { to } 42 \mathrm{~mL} / \mathrm{g} \text { for Sr- } \mathrm{K}_{\mathrm{d}}(2) \text {. Ca system, } 0.3 \text { to } 1.6 \mathrm{~mL} / \mathrm{g} \text { for Sr- } \mathrm{K}_{\mathrm{d}}(2) \text {. In } 4 \mathrm{M} \mathrm{NaNO}_{3}, \mathrm{Sr}-\mathrm{K}_{\mathrm{d}} \text { in Hanford } \\
\text { sediment was } 5 \mathrm{~mL} / \mathrm{g}\left(\mathrm{pH} \text { ), and } 10 \mathrm{~mL} / \mathrm{g}(\mathrm{pH} 10)(12) \text {. Near identical } \mathrm{K}_{\mathrm{d}} \text { values using Savannah River Site Sediments and }\right. \\
30 \% \mathrm{NaNO}_{3}(13) \text {. Sr- } \mathrm{K}_{\mathrm{d}} \text { values measured in low-ionic-strength conditions and with Hanford sediments containing gravel are } \\
\text { presented in Kaplan et al. (17). Based on periodicity considerations, Ra would be expected to sorb more strongly to } \\
\text { sediments than Sr, but no Hanford Ra- } \mathrm{K}_{\mathrm{d}} \text { values are available. Thus, basing Ra- } \mathrm{K}_{\mathrm{d}} \text { estimates on measured Sr- } \mathrm{K}_{\mathrm{d}} \text { values will } \\
\text { likely provide a conservative Ra- } \mathrm{K}_{\mathrm{d}} \text { estimate. }\end{array}$ \\
\hline $\mathrm{Ru}$ & 0 & 0.1 & 0 to 50 & $\begin{array}{l}\text { No gravel-corrected } \mathrm{K}_{\mathrm{d}} \text { data available. May form } \mathrm{RuO}_{4}{ }^{2-} \text { and/or anionic complexes with nitrates and nitrites. Estimate }(3,6 \text {, } \\
\text { 7). }\end{array}$ \\
\hline$\overline{\mathrm{Se}}$ & 0.02 & 0.04 & 0.02 to 1 & $\begin{array}{l}\text { No gravel-corrected } \mathrm{K}_{\mathrm{d}} \text { data available. Anionic. Se } \mathrm{K}_{\mathrm{d}} \text { measured at the ILAW/IDF site had } \mathrm{K}_{\mathrm{d}} \text { values of } 6.7 \pm 0.4 \mathrm{~mL} / \mathrm{g} \\
\text { (14). Results of a Se sorption experiment to Hanford sediments in high ionic strength }\left(\mathrm{NaOH} \text { and } \mathrm{NaOCl}_{4}\right) \text { indicate } \mathrm{Se} \mathrm{K}_{\mathrm{d}} \\
\text { values of } \sim 0 \text { to } 18 \mathrm{~mL} / \mathrm{g} \text {. (15) but } \mathrm{pH} \text { and ionic strength are likely too extreme for zone } 3 \text {. }\end{array}$ \\
\hline $\mathrm{Th}, \mathrm{Zr}$ & 4 & 30 & 4 to 50 & No gravel-corrected $\mathrm{K}_{\mathrm{d}}$ data available. Sandy soil data, 40 to $470 \mathrm{~mL} / \mathrm{g}$ for $\mathrm{Th}(8)$. \\
\hline $\mathrm{U}$ & 0.02 & 0.2 & 0.02 to 5 & $\begin{array}{l}\text { Serne et al. (16) batch Kd data used sediments with some gravel included. To account for having } 90 \% \text { gravel in this zone, } \\
\text { lower the } K_{d} \text { value for the reasonable conservative case even lower }(0.02 \text { from } 0.05 \mathrm{~mL} / \mathrm{g}) \text { than used for sand sediments. }\end{array}$ \\
\hline $\begin{array}{l}\text { (a) The aque } \\
0.01 \text { (bac } \\
\text { (b) Referenc } \\
(1978) ; 8 \\
\text { (1998c); }\end{array}$ & hase is mode & (1976) & $\begin{array}{l}\text { the cemen } \\
\text { is in the san } \\
\text { outson et al. } \\
\text { (1996); } 10\end{array}$ & $\begin{array}{l}\text { and glass leachate emanating from zones } 1 \text { and } 2 ; \mathrm{pH} \text { is between } 8 \text { (background) and } 11 \text {, and the ionic strength is between } \\
\text { d-dominated sequence and is slightly altered due to contact with the moderately caustic aqueous phase (Figure 4.1). } \\
\text { (1978); } 3=\text { Ames and Serne (1991); } 4=\text { Kaplan et al. (1995); } 5=\text { Rhodes (1957a,b); } 6=\text { Ames and Rai (1978); } 7=\text { Barney } \\
\text { 0= Pourbaix (1966); } 11=\text { Kaplan et al. (1998a); } 12=\text { Rhodes and Nelson (1957); } 13=\text { Prout (1959); } 14=\text { Kaplan et al. } \\
\text { 02a); } 17 \text { = Kaplan et al. (2000b); } 18=\text { Robertson et al. (2003). }\end{array}$ \\
\hline
\end{tabular}


Table 5.8. Gravel-Corrected $K_{d}$ Values $\left(K_{d g c}\right)$ for Zones 3a and 4-Far Field in Gravel Sequence $e^{(a)}$

\begin{tabular}{|c|c|c|c|c|}
\hline Radionuclide & $\begin{array}{l}\text { Reasonable } \\
\text { Conservative } \\
\mathbf{K}_{\mathrm{dgc}}(\mathrm{mL} / \mathrm{g}) \\
\end{array}$ & $\begin{array}{l}\text { "Probable" } \\
K_{\text {dgc }}(\mathrm{mL} / \mathrm{g})\end{array}$ & $\begin{array}{c}\mathbf{K}_{\mathrm{dgc}} \text { Range } \\
(\mathrm{mL} / \mathrm{g})\end{array}$ & Justification/References ${ }^{(\mathbf{b})}$ \\
\hline $\begin{array}{l}{ }^{3} \mathrm{H}, \mathrm{Cl}, \mathrm{N} \text { as } \\
\text { nitrate, } \mathrm{Cr} \text { as } \\
\text { chromate, } \\
\text { Tc, } \mathrm{Nb}\end{array}$ & 0 & 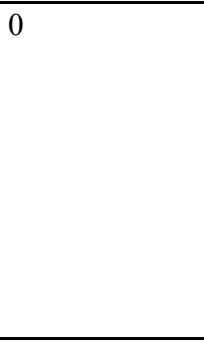 & 0 to 0.06 & $\begin{array}{l}\text { No laboratory results of gravel- } \mathrm{K}_{\mathrm{d}} \text { values available. } \mathrm{N}, \mathrm{Cr}(\mathrm{VI}) \text { and Tc exist predominantly as } \mathrm{NO}_{3}^{-}, \mathrm{CrO}_{4}{ }^{2-} \text {, and } \mathrm{TcO}_{4}^{-} \text {, } \\
\text { respectively. A review of Hanford sediment Tc-K } \mathrm{K}_{\mathrm{d}} \text { values showed a range of }-2.8 \text { to } 0.6 \mathrm{~mL} / \mathrm{g} \text { for } 15 \text { observations; } \\
\text { median was } 0.1-\mathrm{mL} / \mathrm{g}(1) \text {. Later studies did not change this range but did decrease the median slightly to }-0.1 \mathrm{~mL} / \mathrm{g} \\
\text { (2). Negative } \mathrm{K}_{\mathrm{d}} \text { values are possible and may not be an experimental artifact }(2) .{ }^{3} \mathrm{H} \text { is expected to move along with } \\
\text { water. Cl is expected to behave as a dissolved anionic species. Most recent results using ILAW specific borehole } \\
\text { sediments [299-E17-21] yielded Tc- } \mathrm{K}_{\mathrm{d}} \text { of } 0 \mathrm{~mL} / \mathrm{g}(18) \text {. Gravel correction of negative } \mathrm{K}_{\mathrm{d}} \text { values in Estimated } \mathrm{K}_{\mathrm{d}} \text { Range } \\
\text { was assumed to make } \mathrm{K}_{\mathrm{d}} \text { less negative by a factor of } 0.9 \text { because of reduced surface area that would create the anion } \\
\text { exclusion. Limited information available for geochemical behavior of Nb. Nb expected to be anionic at pH }>7 \text {; see } \\
\text { discussion in Robertson et al. (21). }\end{array}$ \\
\hline $\begin{array}{l}\mathrm{Ac}, \mathrm{Am}, \mathrm{Ce} \\
\mathrm{Cm}, \mathrm{Eu}\end{array}$ & 6 & 30 & 6 to 130 & No laboratory results of gravel- $\mathrm{K}_{\mathrm{d}}$ values available. Am- $\mathrm{K}_{\mathrm{d}}: 67$ to $>1,200 \mathrm{~mL} / \mathrm{g}(3)$. Am- $\mathrm{K}_{\mathrm{d}}: 125$ to $833 \mathrm{~mL} / \mathrm{g}$ (4) \\
\hline C & 0.05 & 0.5 & 0.05 to 100 & $\begin{array}{l}\text { No laboratory results of gravel- } \mathrm{K}_{\mathrm{d}} \text { values available. Assumed dominant species: } \mathrm{HCO}_{3} \text {. Three processes will be } \\
\text { acting on the }{ }^{14} \mathrm{C} \text { to take it out of solution: adsorption onto the calcite surface, volatilization as } \mathrm{CO}_{2} \text { gas, and } \\
\text { precipitation into the calcite structure. The latter process is largely irreversible; therefore, it is not well represented by } \\
\text { the } \mathrm{K}_{\mathrm{d}} \text { construct }\left(\mathrm{K}_{\mathrm{d}} \text { assumes that adsorption occurs as readily as desorption). Volatilization is entirely removed from }\right. \\
\text { the definition of the } \mathrm{K}_{\mathrm{d}} \text { construct. In systems that contain higher concentrations of carbonate minerals, such as the } \\
\text { calcrete layer in the } 200 \text { West Area, an appreciably higher } \mathrm{K}_{\mathrm{d}} \text { should be used to account for the isotopic } \\
\text { dilution/precipitation reaction that may occur, a } \mathrm{K}_{\mathrm{d}} \text { of } 100 \mathrm{~mL} / \mathrm{g} \text { would be appropriate for such a system. Since most } \\
\text { of the } 100 \text { and } 200 \text { plateau areas contain }<1 \% \text { carbonate, lower } \mathrm{K}_{\mathrm{d}} \text { values are warranted for these areas, such as } 0.5 \\
\mathrm{~mL} / \mathrm{g} \text {. } \mathrm{K}_{\mathrm{d}} \text { values of }{ }^{14} \mathrm{C} \text { of }>250 \mathrm{~mL} / \mathrm{g} \text { have been measured in calcite }(5) \text {. At } 100 \mathrm{~K} \text { Area, the } \mathrm{C}-14 \text { is widely distributed } \\
\text { down gradient from a major source (crib). Additional references: } 6,7,8,9 \text {, and } 10 \text {. Estimated range. }\end{array}$ \\
\hline Co & 100 & 200 & 100 to 1,250 & $\begin{array}{l}\text { No laboratory results of gravel- } \mathrm{K}_{\mathrm{d}} \text { values available. Na system, } 1,290 \text { to } 2,120 \mathrm{~mL} / \mathrm{g}(11) ; \text { Ca system, } 2,000 \text { to } 3,870 \\
\mathrm{~mL} / \mathrm{g} \text { (11); Hanford sediment/groundwater system } 11,600 \text { to } 12,500 \mathrm{~mL} / \mathrm{g}(12)\end{array}$ \\
\hline Cs & 50 & 200 & 50 to 400 & $\begin{array}{l}\text { No laboratory results of gravel- } \mathrm{K}_{\mathrm{d}} \text { values available. } \\
\text { Na system, } 1,410 \text { to } 1,590 \mathrm{~mL} / \mathrm{g}(11) \\
\text { Hanford sediment/groundwater system, } 540 \text { to } 3,180 \mathrm{~mL} / \mathrm{g}(12) \text {. Most recent results using ILAW specific borehole } \\
\text { sediments [299-E17-21] yielded } \mathrm{K}_{\mathrm{d}} \text { of } 2,030 \pm 597(18) .\end{array}$ \\
\hline I & 0 & 0.02 & 0 to 1.5 & $\begin{array}{l}\text { No laboratory results of gravel- } \mathrm{K}_{\mathrm{d}} \text { values available. A review of Hanford sediment } \mathrm{I}-\mathrm{K}_{\mathrm{d}} \text { values showed a range of } 0.7 \\
\text { to } 15 \mathrm{~mL} / \mathrm{g} \text { for } 9 \text { observations; median was } 0.7-\mathrm{mL} / \mathrm{g} \text { (1). Later studies increased this range to } 0.2 \text { to } 15 \mathrm{~mL} / \mathrm{g} \text {; the } \\
\text { median was decreased to } 0.3 \mathrm{~mL} / \mathrm{g}(2) \text {. Recent results using ILAW specific borehole sediments }[299-\mathrm{E} 17-21] \text { yielded } \\
\mathrm{K}_{\mathrm{d}} \text { of } 0 \mathrm{~mL} / \mathrm{g} \text {. See Kaplan et al. (18) for details. }\end{array}$ \\
\hline $\mathrm{Ni}, \mathrm{Sn}$ & 5 & 30 & 5 to 250 & $\begin{array}{l}\text { No laboratory results of gravel- } \mathrm{K}_{\mathrm{d}} \text { values available. } \\
\text { Ni: Hanford sediment/groundwater system, } 440 \text { to } 2,350 \mathrm{~mL} / \mathrm{g}(12 \text {. A study of a broad range of sediments, including } \\
\text { those from Hanford, had Ni- } \mathrm{K}_{\mathrm{d}} \text { values of } 50 \text { to } 340 \mathrm{~mL} / \mathrm{g}(13) \text {. }\end{array}$ \\
\hline
\end{tabular}


Table 5.8. (contd)

\begin{tabular}{|c|c|c|c|c|}
\hline Radionuclide & \begin{tabular}{|c|} 
Reasonable \\
Conservative \\
$\mathbf{K}_{\mathrm{dgc}}(\mathrm{mL} / \mathrm{g})$
\end{tabular} & $\begin{array}{l}\text { "Probable" } \\
\mathrm{K}_{\text {dgc }}(\mathrm{mL} / \mathrm{g})\end{array}$ & $\begin{array}{c}\mathbf{K}_{\mathrm{dgc}} \text { Range } \\
(\mathrm{mL} / \mathrm{g})\end{array}$ & Justification/References $^{(\mathbf{b})}$ \\
\hline $\mathrm{Np}, \mathrm{Pa}$ & 0.2 & 1.5 & 0.2 to 2.5 & $\begin{array}{l}\text { No laboratory results of gravel- } \mathrm{K}_{\mathrm{d}} \text { values available. A review of Hanford sediment } \mathrm{Np}-\mathrm{K}_{\mathrm{d}} \text { values showed range of } 2.4 \text { to } \\
21.7 \mathrm{~mL} / \mathrm{g} \text { for four observations; median was } 17.8 \mathrm{~mL} / \mathrm{g}(1) \text {. Later studies increased } \mathrm{K}_{\mathrm{d}} \text { values to } 2.2 \text { to } 21.7 \mathrm{~mL} / \mathrm{g} \text {; the } \\
\text { median of these later studies was } 15 \mathrm{~mL} / \mathrm{g}(2) \text {. The dominant protactinium species is assumed to be } \mathrm{PaO}_{2}^{+} \text {and } \mathrm{NpO}_{2}^{+} \text {is } \\
\text { assumed to be a reasonable analog (19). Based on studies conducted at the Whiteshell Laboratories (personal } \\
\text { communications with TT (Chuck) Vandergraaf, Atomic Energy of Canada Limited, Pinawa, Manitoba, Canada), Pa sorbs } \\
\text { appreciably more than Np. Thus, Pa- } \mathrm{K}_{\mathrm{d}} \text { estimates based on measured Np- } \mathrm{K}_{\mathrm{d}} \text { values will be conservative. }\end{array}$ \\
\hline $\mathrm{Pb}$ & 800 & 1,000 & 800 to 8,000 & No laboratory results of gravel- $\mathrm{K}_{\mathrm{d}}$ values available. $\mathrm{pH} 6$ and no competing ions: 13,000 to $79,000 \mathrm{~mL} / \mathrm{g}(14)$ \\
\hline $\mathrm{Pu}$ & 5 & 15 & 5 to 200 & No laboratory results of gravel- $\mathrm{K}_{\mathrm{d}}$ values available. $\mathrm{Pu}(\mathrm{V}, \mathrm{VI}): \mathrm{pH} 4$ to $12: 80$ to $>1,980 \mathrm{~mL} / \mathrm{g}(17)$ \\
\hline $\mathrm{Ra}, \mathrm{Sr}$ & 0.5 & 1.4 & 0.5 to 20 & $\begin{array}{l}\text { Sr } \mathrm{K}_{\mathrm{d}} \text { values: Na system, } 173 \mathrm{~mL} / \mathrm{g}, 49 \text { to } 50 \mathrm{~mL} / \mathrm{g}(11), \text { Ca system, } 8 \text { to } 13 \mathrm{~mL} / \mathrm{g}, 5 \text { to } 19 \mathrm{~mL} / \mathrm{g}(11), 5 \text { to } 120 \mathrm{~mL} / \mathrm{g}(15) \text {, } \\
19.1 \text { to } 21.5 \mathrm{~mL} / \mathrm{g}(12), \text { Na system, } \mathrm{pH} 7 \text { to } 11,14.9 \text { to } 25.1 \mathrm{~mL} / \mathrm{g}(16) \text {. Recent data using ILAW borehole sediment [299- } \\
\text { E17-21] yielded Sr K } \mathrm{d}_{\mathrm{d}} \text { values of } 14.3 \pm 1.6 \mathrm{~mL} / \mathrm{g}(18) \text {. See Appendix A in [18] for Sr } \mathrm{K}_{\mathrm{d}} \text { values with sediments containing } \\
\text { gravel. Based on periodicity considerations, Ra expected to sorb more strongly to sediments than Sr but no Hanford Ra } \mathrm{K}_{\mathrm{d}} \\
\text { values are available. Thus, basing Ra } \mathrm{K}_{\mathrm{d}} \text { estimates on measured Sr K } \mathrm{K}_{\mathrm{d}} \text { values likely provides conservative Ra } \mathrm{K}_{\mathrm{d}} \text { estimate. }\end{array}$ \\
\hline $\mathrm{Ru}$ & 1 & 2 & 1 to 100 & No laboratory results of gravel $\mathrm{K}_{\mathrm{d}}$ values available. Estimated (17 as cited in 11) \\
\hline $\mathrm{Se}$ & 0.3 & 0.7 & 0.3 to 1.5 & $\begin{array}{l}\text { No lab results of gravel } \mathrm{K}_{\mathrm{d}} \text { values available. Hanford groundwater/sediment system: }-3.44 \text { to } 0.78 \mathrm{~mL} / \mathrm{g}(12) \text {. Most } \\
\text { recent data using ILAW borehole sediment [299-E17-21], which did not contain measurable amounts of gravel, yielded } \\
\mathrm{K}_{\mathrm{d}} \text { values ranging from } 3.75 \text { to } 10.85 \mathrm{~mL} / \mathrm{g} \text { and had an average of } 6.7 \pm 1.9 \mathrm{~mL} / \mathrm{g}(18) \text {. }\end{array}$ \\
\hline Th, Zr & 4 & 100 & 4 to 250 & Estimated. No laboratory results of gravel- $\mathrm{K}_{\mathrm{d}}$ values available. $\mathrm{Zr}$ : $\mathrm{pH} 6$ to $12: 90$ to $>2,000 \mathrm{~mL} / \mathrm{g}(15)$ \\
\hline $\mathrm{U}$ & 0.1 & 1.0 & 0.01 to 7 & $\begin{array}{l}\text { Serne et al. (20) used } 300 \text { Area Hanford formation sediments with some gravel and got a range of } \mathrm{K}_{\mathrm{d}} \text { values from } \sim 0 \text { to } 7 \\
\mathrm{~mL} / \mathrm{g} \text {. } \mathrm{U} \mathrm{K} \mathrm{K}_{\mathrm{d}} \text { values were highly influenced by bicarbonate/carbonate concentration and } \mathrm{pH} \text {. pH of nonimpacted gravel } \\
\text { sediments at Hanford is } \sim 8 \text { and bicarbonate/carbonate concentrations are }<5 \mathrm{meq} / \mathrm{L} \text {. For sediments with } 90 \% \text { gravel but } \\
\text { normal solution chemistry, assume a very conservative } \mathrm{K}_{\mathrm{d}} \text { value would be } 10 \% \text { of the most probable case or } 0.1 \mathrm{~mL} / \mathrm{g} \text {. } \\
\text { A review of Hanford sediment } \mathrm{U}-\mathrm{K}_{\mathrm{d}} \text { values showed range of } 0.1 \text { to } 79.3 \mathrm{~mL} / \mathrm{g} \text { for } 13 \text { observations; median was } 0.6-\mathrm{mL} / \mathrm{g} \\
\text { (1). Results from later studies support the range (2). In all reported data, some } \mathrm{U} \text { was adsorbed by Hanford sediments and } \\
>90 \% \text { of the values were between } 0.6 \text { and } 4 \mathrm{~mL} / \mathrm{g} \text {. Most recent work with the ILAW Borehole sediment [299-E17-21] } \\
\text { yielded } \mathrm{K}_{\mathrm{d}} \text { of } 0.6 \pm 0.1 \text { for a sand sediment but no gravel correction information was available from this data set. See (18). }\end{array}$ \\
\hline \multicolumn{5}{|c|}{ 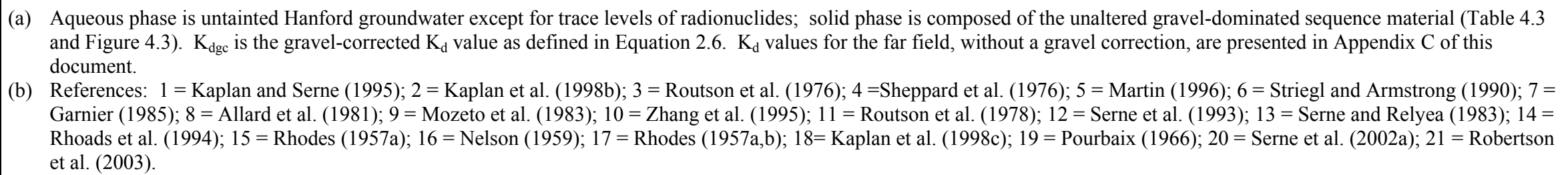 } \\
\hline
\end{tabular}


Table 5.9. $\quad \mathrm{K}_{d}$ Values for Zone 5-Unconfined Far-Field Aquifer Conditions ${ }^{(\mathrm{a})}$

\begin{tabular}{|c|c|c|c|c|}
\hline Radionuclide & $\begin{array}{l}\text { Reasonably } \\
\text { Conservative } \\
\mathbf{K}_{\mathrm{d}}(\mathrm{mL} / \mathrm{g})\end{array}$ & $\begin{array}{c}\text { “Best” } \mathbf{K}_{\mathbf{d}} \\
(\mathrm{mL} / \mathrm{g})\end{array}$ & $\begin{array}{c}\mathbf{K}_{\mathbf{d}} \text { Range } \\
(\mathbf{m L} / \mathbf{g})\end{array}$ & Justification/References ${ }^{(\mathbf{b})}$ \\
\hline $\begin{array}{l}{ }^{3} \mathrm{H}, \mathrm{Cl}, \mathrm{Tc}, \mathrm{N} \\
\text { as nitrate, } \\
\mathrm{Cr}(\mathrm{VI}) \text { as } \\
\text { chromate, } \mathrm{Nb}\end{array}$ & 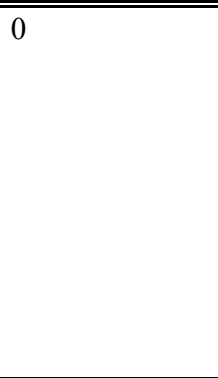 & 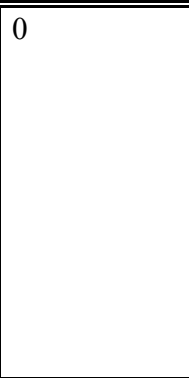 & 0 to 0.6 & $\begin{array}{l}\text { Tc exists predominantly as } \mathrm{TcO}_{4}^{-} \text {. A review of Hanford sediment Tc- } \mathrm{K}_{\mathrm{d}} \text { values showed a range of }-2.8 \text { to } 0.6 \mathrm{~mL} / \mathrm{g} \text { for } \\
15 \text { observations; median was } 0.1 \mathrm{~mL} / \mathrm{g}(1) \text {. Later studies did not change this range but did decrease the median } \\
\text { slightly to }-0.1 \mathrm{~mL} / \mathrm{g}(2) \text {. Negative } \mathrm{K}_{\mathrm{d}} \text { values are physically possible and may not be an experimental artifact (2). }{ }^{3} \mathrm{H} \\
\text { is expected to move along with water. Cl and nitrate are expected to behave as a dissolved anionic species. Most } \\
\text { recent results using ILAW specific borehole sediments [299-E17-21 and } 299 \text {-E21-24] yielded Tc- } \mathrm{K}_{\mathrm{d}} \text { of } 0 \mathrm{~mL} / \mathrm{g} \text {. See } \\
\text { Kaplan et al. (18) and Um and Serne (19) for details. Cantrell et al. (21) lists } \mathrm{K}_{\mathrm{d}} \text { values for } \mathrm{Cr}(\mathrm{VI}), \text { nitrate, and Tc in } \\
\text { Tables } 10,12 \text {, and } 15 \text {, respectively that give ranges of } 0 \text { to } 1,0 \text { (all groundwater values), and } 0 \text { to } 0.1 \mathrm{~mL} / \mathrm{g} \text {, } \\
\text { respectively. These ranges are used in SAC to perform stochastic predictions for contaminant transport in natural } \\
\text { Hanford groundwater/aquifer predictions. Limited information available for geochemical behavior of Nb. Nb } \\
\text { expected to be anionic at pH }>7 \text {; see discussion in Robertson et al. (22). }\end{array}$ \\
\hline $\begin{array}{l}\mathrm{Ac}, \mathrm{Am}, \mathrm{Ce} \\
\mathrm{Cm}, \mathrm{Eu}\end{array}$ & 60 & 300 & 60 to 1,300 & Am- $K_{d}: 67$ to greater than $1,200 \mathrm{~mL} / \mathrm{g}(3) . A m-K_{d}: 125$ to $833 \mathrm{~mL} / \mathrm{g} \mathrm{(4)}$ \\
\hline $\mathrm{C}$ & 0.5 & 5 & 0.5 to 1,000 & $\begin{array}{l}\text { Assumed dominant species: } \mathrm{HCO}_{3}^{-} \text {. Three processes will be acting on the }{ }^{14} \mathrm{C} \text { to take it out of solution: adsorption } \\
\text { onto the calcite surface, volatilization as } \mathrm{CO}_{2} \text { gas, and precipitation into the calcite structure. The latter process is } \\
\text { largely irreversible; therefore, it is not well represented by the } \mathrm{K}_{\mathrm{d}} \text { construct }\left(\mathrm{K}_{\mathrm{d}} \text { assumes that adsorption occurs as }\right. \\
\text { readily as desorption). Volatilization is entirely removed from the definition of the } \mathrm{K}_{\mathrm{d}} \text { construct. In systems that } \\
\text { contain higher concentrations of carbonate minerals, such as the calcrete layer in the } 200 \text { West Area, an appreciably } \\
\text { higher } \mathrm{K}_{\mathrm{d}} \text { should be used to account for the isotopic dilution } / \text { precipitation reaction that may occur. A } \mathrm{K}_{\mathrm{d}} \text { of } 100 \mathrm{~mL} / \mathrm{g} \\
\text { would be appropriate for such a system. Since most of the } 100 \text { and } 200 \text { plateau areas contain }<1 \% \text { carbonate, lower } \mathrm{K}_{\mathrm{d}} \\
\text { values are warranted for these areas, such as } 0.5 \mathrm{~mL} / \mathrm{g} \text {. } \mathrm{K}_{\mathrm{d}} \text { values of }{ }^{14} \mathrm{C} \text { of }>250 \mathrm{~mL} / \mathrm{g} \text { have been measured in calcite } \\
\text { (5). At } 100 \mathrm{~K} \text {, the C-14 is widely distributed down gradient from a major source (crib) associated with reactor } \\
\text { operations. (Additional references: } 6,7,8,9,10 \text { ). Estimated range. }\end{array}$ \\
\hline Co & 1000 & 2000 & $\begin{array}{l}1,000 \text { to } \\
12,500\end{array}$ & $\begin{array}{l}\text { Na system, } 1,290 \text { to } 2,120 \mathrm{~mL} / \mathrm{g}(11) \\
\text { Ca system, } 2,000 \text { to } 3,870 \mathrm{~mL} / \mathrm{g}(11) \\
\text { Hanford sediment/groundwater system } 11,600 \text { to } 12,500 \mathrm{~mL} / \mathrm{g}(12)\end{array}$ \\
\hline Cs & 500 & 2000 & 500 to 4,000 & $\begin{array}{l}\text { Na system, } 1,410 \text { to } 1,590 \mathrm{~mL} / \mathrm{g}(11) \\
\text { Hanford sediment/groundwater system, } 540 \text { to } 3,180 \mathrm{~mL} / \mathrm{g}(12) \text {. Most recent results using ILAW specific borehole } \\
\text { sediments [299-E17-21] yielded } \mathrm{K}_{\mathrm{d}} \text { of } 2,030 \pm 597 \text {. See Kaplan et al. (18) for details. }\end{array}$ \\
\hline I & 0 & 0.25 & 0.0 to 15 & $\begin{array}{l}\text { A review of Hanford sediment I- } \mathrm{K}_{\mathrm{d}} \text { values showed a range of } 0.7 \text { to } 15 \mathrm{~mL} / \mathrm{g} \text { for } 9 \text { observations; median was } 0.7 \mathrm{~mL} / \mathrm{g} \\
\text { (1). Later studies increased this range to } 0.2 \text { to } 15 \mathrm{~mL} / \mathrm{g} \text {; the median was decreased to } 0.3 \mathrm{~mL} / \mathrm{g} \text { (2). Results using } \\
\text { ILAW specific borehole sediments [299-E17-21] yielded } \mathrm{K}_{\mathrm{d}} \text { of } 0 \mathrm{~mL} / \mathrm{g}(18) \text {, but more recent results by Um et al. [19] } \\
\text { for ILAW borehole } 299 \text {-E24-21 show non zero } \mathrm{K}_{\mathrm{d}} \text { with an average value of } 0.2 \text { to } 0.3 \mathrm{~mL} / \mathrm{g} \text { for far-field. Cantrell et } \\
\text { al. } 2003 \text { [21] recommends a range of } 0 \text { to } 2 \mathrm{~mL} / \mathrm{g} \text { for general Hanford transport conditions performed by SAC. }\end{array}$ \\
\hline $\mathrm{Ni}, \mathrm{Sn}$ & 50 & 300 & 50 to 2,500 & $\begin{array}{l}\text { Ni: Hanford sediment/groundwater system, } 440 \text { to } 2,350 \mathrm{~mL} / \mathrm{g} \text { (12). A study of a broad range of sediments, including } \\
\text { those from Hanford, had Ni-K } \mathrm{K}_{\mathrm{d}} \text { values of } 50 \text { to } 340 \mathrm{~mL} / \mathrm{g}(13) \text {. }\end{array}$ \\
\hline
\end{tabular}


Table 5.9. (contd)

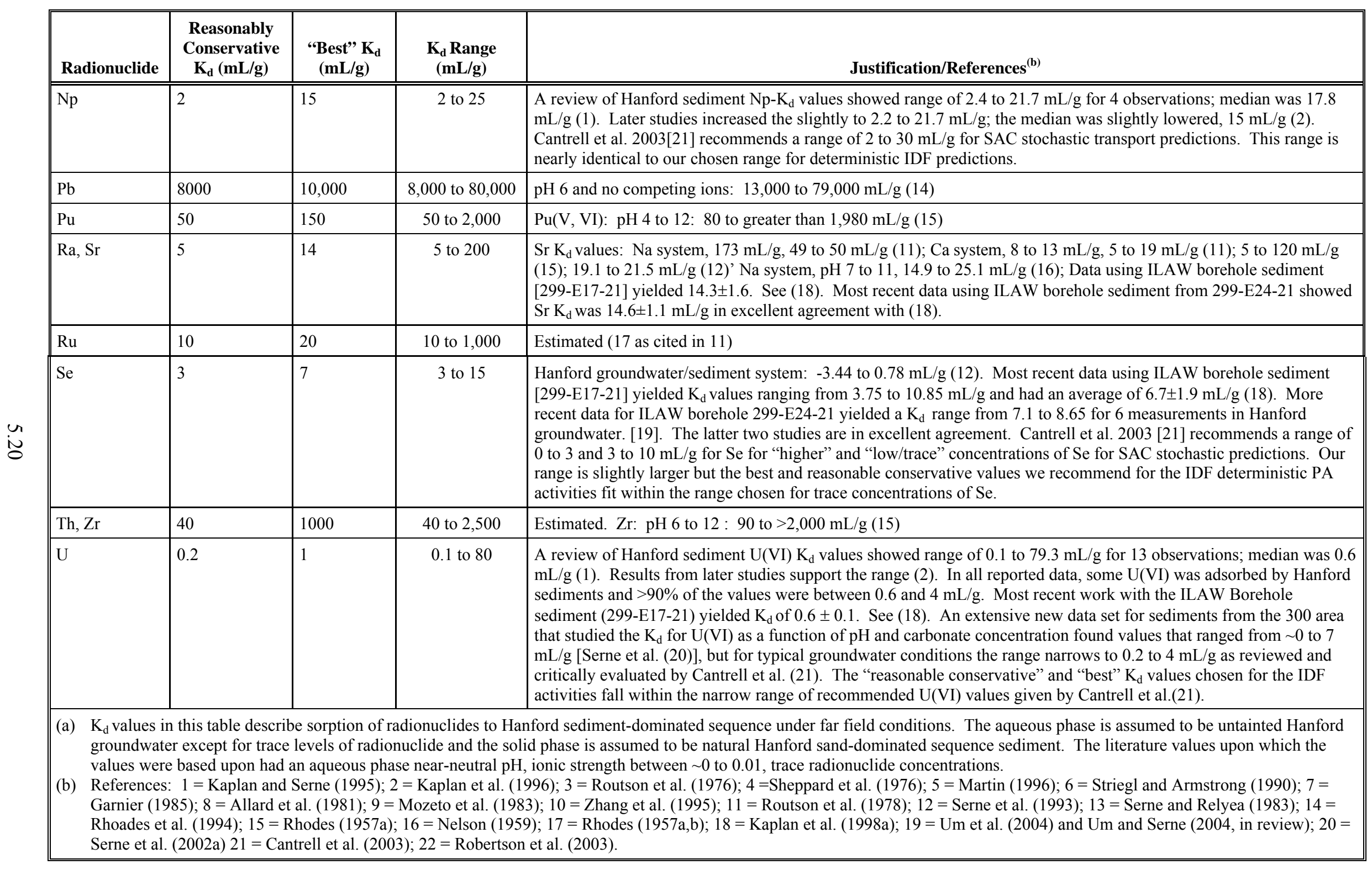




\subsection{History of $K_{d}$ Values Selected for Key Contaminants of Concern}

This data package is the third compilation of $K_{d}$ values prepared for use in an ILAW/IDF PA. Over time, three sets of calculations have been performed to predict the consequences of burying vitrified wastes in the south-central portion of the 200 East Area at Hanford Site. The three efforts to evaluate future risks associated with onsite burial are known as the 1998 ILAW PA (Mann et al. 1998), the 2001 ILAW PA (Mann et al. 2001) and the supplemental ILAW waste form initial selection risk assessment (Mann et al. 2003b). The fourth effort to predict future impacts and risks associated with the burial of wastes in the IDF is the 2005 IDF PA, to be completed next year.

Selection and documentation of $\mathrm{K}_{\mathrm{d}}$ values and empirical solubility concentration limits are the subject of this report. The $\mathrm{K}_{\mathrm{d}}$ values recommended for some of the potentially mobile contaminants of concern for the three sets of PA calculations already completed and the soon-to-start 2005 IDF PA have evolved as the Hanford-specific sorption database has increased and knowledge of the fate and transport properties of these key contaminants has improved. Table 6.1 lists the $\mathrm{K}_{\mathrm{d}}$ values that were recommended for the key mobile contaminants (and major dose/chemical risk drivers) for each of the three activities and the upcoming 2005 IDF PA. Not all contaminants were assessed in each PA, but $\mathrm{K}_{\mathrm{d}}$ values were recommended for a large suite of contaminants for each assessment. This section describes the reason for changes in $K_{d}$ values selected over time for the listed key contaminants. As shown in Table 6.1, there is essentially no change in the recommended $\mathrm{K}_{\mathrm{d}}$ values for nitrate, $\mathrm{Cr}(\mathrm{VI})$, and ${ }^{99} \mathrm{Tc}$. Thus these three mobile contaminants will not be discussed further.

\section{1 $K_{d}$ Values for ${ }^{129} I$}

The $\mathrm{K}_{\mathrm{d}}$ values for ${ }^{129} \mathrm{I}$ have evolved with time as more Hanford-specific conditions were measured. The $K_{d}$ values recommended for the 1998 ILAW PA were influenced by the general literature, which suggests moderate adsorption. Thus a $\mathrm{K}_{\mathrm{d}}$ value of $3 \mathrm{~mL} / \mathrm{g}$ for ${ }^{129} \mathrm{I}$ was chosen at that time. Between 1998 and 2001, several Hanford-specific iodide adsorption studies yielded inconsistent results (Kaplan et al. $1998 \mathrm{~b}$; 2003) especially when using solutions with $\mathrm{pH}$ values greater than natural (ambient) $\mathrm{pH} 8$ conditions. Because of the uncertainty and lack of a clear understanding of the controlling mechanisms in these empirical tests, we made a conservative recommendation and selected a $\mathrm{K}_{\mathrm{d}}$ of $0 \mathrm{~mL} / \mathrm{g}$ for ${ }^{129} \mathrm{I}$ for the 2001 ILAW PA calculations. After the 2001 PA, we focused new IDF-funded testing on iodide adsorption using Hanford sediments. We are now confident that there is, in fact, low adsorption of iodide.

The STORM code was used in the 2001 ILAW PA to predict the chemical evolution of the pore water in the vadose zone below the ILAW IDF. Table 6.2 lists the long-term, steady-state chemical composition of glass leachate and vadose zone pore water predicted by the STORM code for the 2001 ILAW PA. The 2001 STORM code calculations indicated that the pore water for the entire vadose zone below the IDF would be similar to this composition in the long term. Recent iodide adsorption measurements by Um and Serne ${ }^{(a)}$ using a simulated glass leachate based on the composition in Table 6.2 shows a decreased adsorption at a $\mathrm{pH}$ value of 9.5 , but the $\mathrm{K}_{\mathrm{d}}$ is consistently greater than zero (Section 3.2.3). We

(a) Um W and RJ Serne. 2004. "Sorption and Transport Behavior of Radionuclides in the Proposed Low-Level Radioactive Waste Disposal Facility at the Hanford Site, Washington." Submitted to Radiochimica Acta. 
Table 6.1. Evolution of Recommended $\mathrm{K}_{\mathrm{d}}$ Values $(\mathrm{mL} / \mathrm{g})$ for Selected Key Contaminants

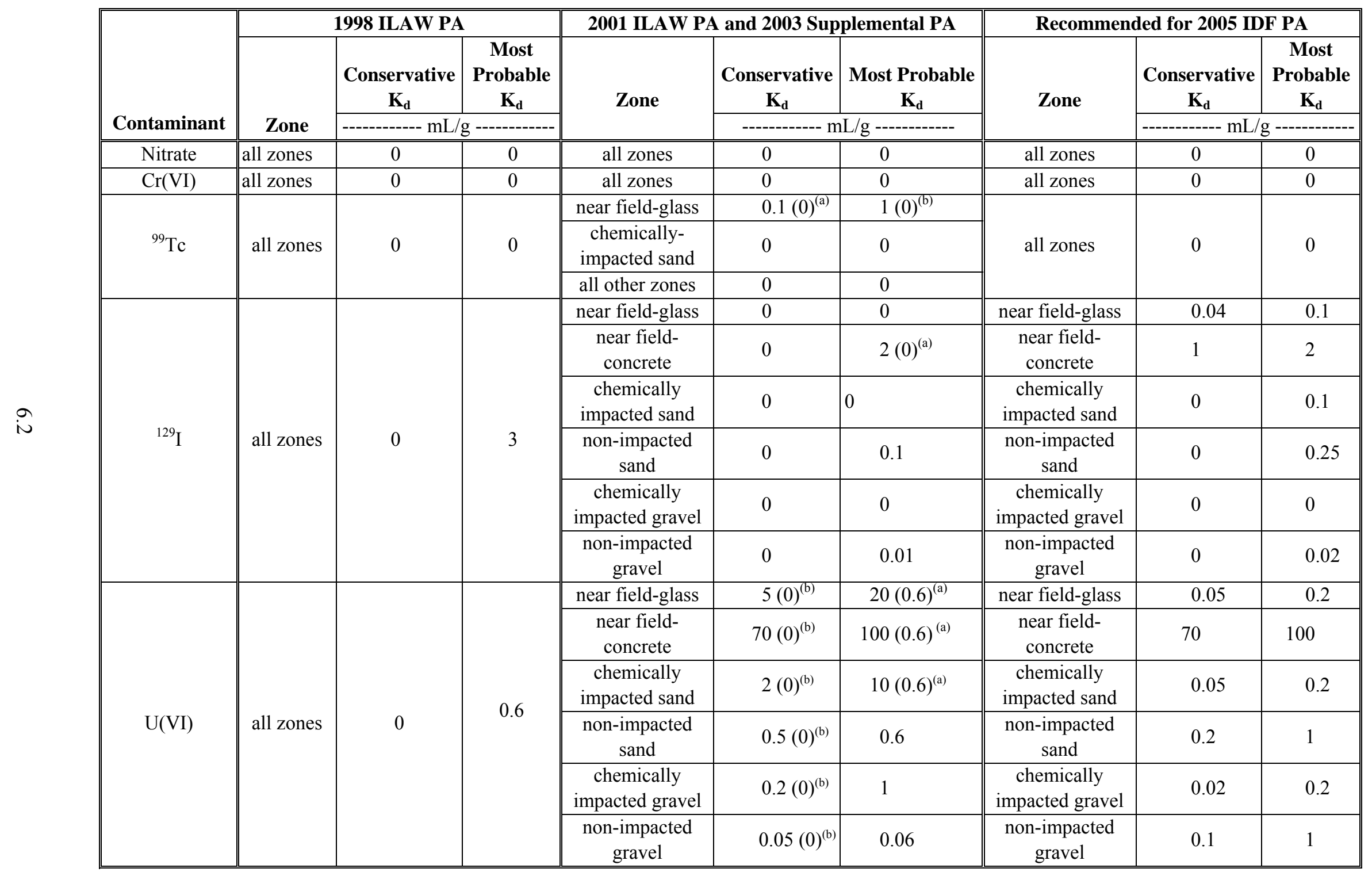


Table 6.1. (contd)

\begin{tabular}{|c|c|c|c|c|c|c|c|c|c|}
\hline \multirow[b]{3}{*}{ Contaminant } & \multicolumn{3}{|c|}{1998 ILAW PA } & \multicolumn{3}{|c|}{2001 ILAW PA and 2003 Supplemental PA } & \multicolumn{3}{|c|}{ Recommended for 2005 IDF PA } \\
\hline & \multirow[b]{2}{*}{ Zone } & $\begin{array}{c}\text { Conservative } \\
\mathbf{K}_{\mathbf{d}} \\
\end{array}$ & \begin{tabular}{|c|} 
Most \\
Probable \\
$\mathbf{K}_{\mathbf{d}}$ \\
\end{tabular} & \multirow[t]{2}{*}{ Zone } & \begin{tabular}{|c} 
Conservative \\
$\mathbf{K}_{\mathbf{d}}$ \\
\end{tabular} & $\begin{array}{c}\text { Most Probable } \\
\mathbf{K}_{\mathrm{d}} \\
\end{array}$ & \multirow[t]{2}{*}{ Zone } & \begin{tabular}{|c|} 
Conservative \\
$\mathbf{K}_{\mathbf{d}}$ \\
\end{tabular} & $\begin{array}{c}\text { Most } \\
\text { Probable } \\
K_{\mathbf{d}} \\
\end{array}$ \\
\hline & & \multicolumn{2}{|c|}{ 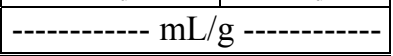 } & & \multicolumn{2}{|c|}{ 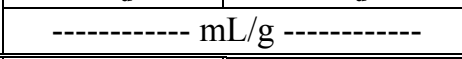 } & & \multicolumn{2}{|c|}{------- mL/g --------- } \\
\hline \multirow{6}{*}{${ }^{79} \mathrm{Se}$} & \multirow{6}{*}{ all zones } & \multirow{6}{*}{0} & \multirow{6}{*}{0} & near field-glass & 0 & 0 & near field-glass & 0 & 1 \\
\hline & & & & $\begin{array}{l}\text { near field- } \\
\text { concrete }\end{array}$ & 0 & 1 & $\begin{array}{l}\text { near field- } \\
\text { concrete }\end{array}$ & 0 & 1 \\
\hline & & & & $\begin{array}{c}\text { chemically } \\
\text { impacted sand }\end{array}$ & 2 & 4 & $\begin{array}{c}\text { chemically } \\
\text { impacted sand }\end{array}$ & 1 & 2 \\
\hline & & & & $\begin{array}{l}\text { non-impacted } \\
\text { sand }\end{array}$ & 3 & 7 & $\begin{array}{l}\text { non-impacted } \\
\text { sand }\end{array}$ & 3 & 7 \\
\hline & & & & $\begin{array}{c}\text { chemically } \\
\text { impacted gravel }\end{array}$ & 0.2 & 0.4 & $\begin{array}{c}\text { chemically } \\
\text { impacted gravel }\end{array}$ & 0.02 & 0.04 \\
\hline & & & & $\begin{array}{c}\text { non-impacted } \\
\text { gravel }\end{array}$ & 0.3 & 0.7 & $\begin{array}{l}\text { non-impacted } \\
\text { gravel }\end{array}$ & 0.3 & 0.7 \\
\hline \multicolumn{10}{|c|}{$\begin{array}{l}\text { (a) In the } 2001 \text { ILAW PA calculations, some of the recommended } K_{d} \text { values were not used and more conservative numbers were selected. The more conservative number } \\
\text { used in those PA code calculations are shown in parentheses }\end{array}$} \\
\hline (b) & $\begin{array}{l}\text { AW PA ce } \\
\text { ed. }\end{array}$ & lations, a sensiti & & n was completed usin & $\lg K_{d}$ values of 0 & $\mathrm{~nL} / \mathrm{g}$ for the conse & ative $K_{d}$ values for & $\mathrm{J}(\mathrm{VI})$ in the vado & e zone \\
\hline
\end{tabular}


Table 6.2. Predicted Composition of Glass Leachate and Long-Term Vadose Zone Pore Water Based on the 2001 STORM Code Calculations

\begin{tabular}{|c|c|c|}
\hline Constituent & \multicolumn{2}{|c|}{ Concentration } \\
\hline \multicolumn{3}{|c|}{$\mathrm{pH}$} \\
\hline \multicolumn{3}{|c|}{ Ionic Strength $=$} \\
\hline & ------- mM ------- & -- meq/L -- \\
\hline $\mathrm{Al}$ & 0.2 & 0.60 \\
\hline $\mathrm{B}$ & 7.23 & 21.69 \\
\hline $\mathrm{Ca}$ & 0.0001 & 0.00 \\
\hline $\mathrm{CO}_{3}{ }^{2-}$ & 7.54 & 15.08 \\
\hline $\mathrm{HCO}_{3}^{-}$ & 26.8 & 26.80 \\
\hline $\mathrm{Cr}$ & 0.00716 & 0.01 \\
\hline $\mathrm{Fe}$ & $1.00 \times 10^{-7}$ & 0.00 \\
\hline $\mathrm{K}$ & 0.112 & 0.11 \\
\hline $\mathrm{Mg}$ & 0.675 & 1.35 \\
\hline $\mathrm{Na}$ & 38.5 & 38.50 \\
\hline $\mathrm{Si}$ & 1.95 & \\
\hline $\mathrm{Ti}$ & 0.000226 & 0.00 \\
\hline $\mathrm{Zn}$ & 0.870 & 1.74 \\
\hline $\mathrm{Zr}$ & $5.51 \times 10^{-7}$ & 0.00 \\
\hline
\end{tabular}

have not studied the adsorption of iodide onto gravel-dominated sediments to determine whether the gravel-correction construct described in this report is viable. Thus for conservatism, we have decreased the $K_{d}$ values measured for ${ }^{129}$ I on sands by a factor of 10 to estimate $K_{d}$ values for the gravel-dominated zones. Table 6.1 lists ${ }^{129} \mathrm{I} \mathrm{K}_{\mathrm{d}}$ values recommended for the 2005 IDF PA for a conservative sensitivity calculation and for the most probable or base case. The most probable $\mathrm{K}_{\mathrm{d}}$ values are low for ${ }^{129} \mathrm{I}$, but greater than zero.

\section{2 $\quad K_{d}$ Values for $U(V I)$}

The selection of recommended $\mathrm{K}_{\mathrm{d}}$ values for $\mathrm{U}(\mathrm{VI})$ has been difficult over time because of the great sensitivity of $\mathrm{U}(\mathrm{VI})$ adsorption to the $\mathrm{pH}$ and concentration of dissolved carbonate/bicarbonate in fluids used in adsorption tests [see general discussion of U(VI) aqueous speciation in Section 3.7.1 and adsorption in Section 3.7.3]. In 1998, the value of $0.6 \mathrm{~mL} / \mathrm{g}$ was recommended based on some Hanford-specific work and much general literature that indicated some adsorption for U(VI) on coarse-grained sediments with low organic matter content and slightly alkaline $\mathrm{pH}$ in bicarbonate-dominated waters. For chemically impacted zones, $\mathrm{K}_{\mathrm{d}}$ values for $\mathrm{U}(\mathrm{VI})$ much greater than $0.6 \mathrm{~mL} / \mathrm{g}$ were recommended for the 2001 ILAW PA. Recommendation of these values was based on information from the studies by Kaplan et al. (1998a), literature reviews on radionuclide sorption in cement (Krupka and Serne 1998), and analyses of contaminated sediment columns that showed relative mobility of uranium was significantly less than those of nitrate and ${ }^{99} \mathrm{Tc}$ in vadose zone sediments under Hanford Site tanks that had leaked in the past. Our selection was influenced by the fact that uranium appeared to adsorb or precipitate readily from liquids contacting Hanford sediments when the $\mathrm{pH}$ was raised from ambient to more alkaline values. There were numerous empirical observations to support this conclusion. As shown in Table 6.1, our 
recommended $\mathrm{K}_{\mathrm{d}}$ values for $\mathrm{U}(\mathrm{VI})$ in impacted zones were $10 \mathrm{~mL} / \mathrm{g}$ or greater. The 2001 ILAW PA calculations binned various contaminants to reduce computation run costs such that many contaminants with recommended $\mathrm{K}_{\mathrm{d}}$ values greater than $0.6 \mathrm{~mL} / \mathrm{g}$ were binned and assumed to have a $\mathrm{K}_{\mathrm{d}}$ equal to $0.6 \mathrm{~mL} / \mathrm{g}$. As long as the travel times were greater than 10,000 years at the chosen receptor location or if the consequences (dose or concentration) were significantly below levels of concern, no calculations were performed using the recommended larger $K_{d}$ values. Such was the case in the 2001 ILAW PA.

Since 2001, several additional studies have been completed at Hanford, where uranium adsorption has been studied and the chemical composition of the glass leachate has become available. The STORM code also predicted that the entire vadose zone below the ILAW glass disposal cell would be affected by the slow leaching of the waste glass such that the pore fluids would have the composition listed in Table 6.2. This fluid is dominated by dissolved sodium and borate from the glass and by dissolved bicarbonate/ carbonate from the assumed equilibration with atmospheric carbon dioxide. The predicted $\mathrm{pH}$ of 9.5 is another key factor to consider because the solubility of dissolved inorganic carbon (bicarbonate/ carbonate) increases in aqueous solutions at equilibrium with the atmosphere as $\mathrm{pH}$ increases and inorganic carbon forms strong anionic aqueous complexes with $\mathrm{U}(\mathrm{VI})$ [e.g., $\mathrm{UO}_{2}\left(\mathrm{CO}_{3}\right)_{2}{ }^{2-}$ and $\mathrm{UO}_{2}\left(\mathrm{CO}_{3}\right)_{3}{ }^{4-}$ ] that exhibit minimal adsorption and are highly soluble reactions (see discussion in Section 3.7.1).

Detailed U(VI) sorption studies using fluids with varying chemical composition (pH, bicarbonate/ carbonate, and ionic strength) and a coarse Hanford formation sand (included $\sim 2 \%$ gravel) sediment from the 300 Area of Hanford were reported by Serne et al. (2002a). The U(VI) $K_{d}$ values they measured in a high ionic-strength-simulated pore water solution whose composition is listed in Table 6.3 are listed in Tables 6.4 through 6.6. The chemical composition of the "high ionic-strength water" in Serne et al. (2002a) is similar in composition (dominated by dissolved sodium and inorganic carbon), but slightly more dilute, than that predicted glass leachate as given in Table 6.2. Uranium $\mathrm{K}_{\mathrm{d}}$ values obtained upon contact of the high ionic strength solution at $\mathrm{pH} 7.5 \pm 0.3$ with the 300 Area Hanford sediment are shown in Table 6.4 as a function of the starting concentrations of dissolved $\mathrm{U}(\mathrm{VI})$. The $\mathrm{K}_{\mathrm{d}}$ values vary from 0.28 to $0.56 \mathrm{~mL} / \mathrm{g}$. Additional results from Serne et al. (2002a) with the high ionic-strength solution as a function of $\mathrm{pH}$ show that when the $\mathrm{pH}$ is increased slightly above 7.5 , the $\mathrm{K}_{\mathrm{d}}$ values decrease significantly, as shown in Table 6.5. Serne et al. (2002a) also conducted experiments using a simpler sodium bicarbonate-sulfate solution to evaluate the impact of total dissolved inorganic carbon bicarbonate/

Table 6.3. Composition of the High Ionic-Strength-Simulated Pore Water Solution Used for U(VI) $K_{d}$ Measurements by Serne et al. (2002a)

\begin{tabular}{||l|c|c||}
\hline \multirow{2}{*}{ Constituent } & \multicolumn{2}{|c|}{ Concentration } \\
\cline { 2 - 3 } \multicolumn{1}{|c|}{ Cations } & & 20 \\
\hline Anions & & 20 \\
\hline $\mathrm{Ca}$ & 2 & 4 \\
\hline $\mathrm{Na}$ & 16 & 16 \\
\hline $\mathrm{HCO}_{3}^{-}$ & 10 & 10 \\
\hline $\mathrm{NO}_{3}^{-}$ & 4 & 4 \\
\hline $\mathrm{SO}_{4}{ }^{-2}$ & 3 & 6 \\
\hline
\end{tabular}


Table 6.4. $\quad \mathrm{K}_{\mathrm{d}}$ Values (mL/g) Measured for U(VI) by Serne et al. (2002a) at Different Initial Concentrations of Dissolved U(VI) Using Hanford Formation Coarse Sand and High IonicStrength Solution $(\mathrm{pH}=7.5 \pm 0.3)$ with the Composition Listed in Table 6.3

\begin{tabular}{|c|c|c|c|}
\hline \multirow{2}{*}{$\begin{array}{c}\text { Initial Conc. } \\
\text { Dissolved U(VI) } \\
\text { (ppb) }\end{array}$} & \multirow{2}{*}{$\begin{array}{l}\text { Sample } \\
\text { Number }\end{array}$} & $\mathbf{K}_{\mathbf{d}}$ & Average $\mathbf{K}_{\mathbf{d}}$ \\
\hline & & \multicolumn{2}{|c|}{ - } \\
\hline \multirow{2}{*}{50} & B11493-1 & 0.36 & \multirow{2}{*}{0.28} \\
\hline & B11493-2 & 0.20 & \\
\hline \multirow{2}{*}{250} & B11493-3 & 0.54 & \multirow{2}{*}{0.43} \\
\hline & B11493-4 & 0.32 & \\
\hline \multirow{2}{*}{500} & B11493-5 & 0.58 & \multirow{2}{*}{0.56} \\
\hline & B11493-6 & 0.55 & \\
\hline \multirow{2}{*}{750} & B11493-7 & 0.49 & \multirow{2}{*}{0.45} \\
\hline & B11493-8 & 0.40 & \\
\hline \multirow{2}{*}{1,500} & B11493-9 & 0.55 & \multirow{2}{*}{0.53} \\
\hline & B11493-10 & 0.51 & \\
\hline \multirow{2}{*}{3,000} & B11493-11 & 0.45 & \multirow{2}{*}{0.44} \\
\hline & B11493-13 & 0.43 & \\
\hline \multirow{2}{*}{5,000} & B11493-12 & 0.35 & \multirow{2}{*}{0.35} \\
\hline & B11493-14 & 0.36 & \\
\hline
\end{tabular}

Table 6.5. $\quad \mathrm{K}_{\mathrm{d}}$ Values (mL/g) Measured for U(VI) by Serne et al. (2002a) as a Function of $\mathrm{pH}$ Using Hanford Formation Coarse Sand and High Ionic-Strength Solution with the Composition Listed in Table 6.3

\begin{tabular}{|c|c|c|c|}
\hline $\begin{array}{c}\text { Initial Conc. } \\
\text { Dissolved U(VI) } \\
\text { (ppb) }\end{array}$ & $\begin{array}{l}\text { Sample } \\
\text { Number }\end{array}$ & pH & $K_{d}(\mathrm{~mL} / \mathrm{g})$ \\
\hline \multirow{6}{*}{500} & High I.S.-1 & 6.26 & 137.8 \\
\hline & High I.S.-2 & 6.77 & 8.63 \\
\hline & High I.S.-3 & 7.49 & 0.31 \\
\hline & High I.S.-4 & 7.36 & 0.36 \\
\hline & High I.S.-5 & 7.93 & $-0.09^{\mathrm{a}}$ \\
\hline & High I.S.-6 & 7.97 & $-0.07^{(\mathrm{a})}$ \\
\hline \multirow{6}{*}{3,000} & High I.S.-7 & 6.53 & 6.09 \\
\hline & High I.S.-8 & 6.68 & 3.93 \\
\hline & High I.S.-9 & 7.26 & 0.16 \\
\hline & High I.S.-10 & 7.11 & 0.20 \\
\hline & High I.S.-11 & 7.90 & 0.02 \\
\hline & High I.S.-12 & 7.89 & 0.03 \\
\hline \multicolumn{4}{|c|}{$\begin{array}{l}\text { (a) The concentration of adsorbed } \mathrm{U}(\mathrm{VI}) \text { used to calculate the } \mathrm{K}_{\mathrm{d}} \text { was } \\
\text { determined by subtracting the total amount of dissolved } \mathrm{U}(\mathrm{VI}) \text { from the } \\
\text { initial concentrations of dissolved } \mathrm{U}(\mathrm{VI}) \text {. For conditions of very low } \\
\text { adsorption of } \mathrm{U}(\mathrm{VI}) \text {, negative } \mathrm{K}_{\mathrm{d}} \text { values are therefore possible, and should } \\
\text { be considered to equal } 0 \mathrm{~mL} / \mathrm{g} \text {. }\end{array}$} \\
\hline
\end{tabular}


carbonate on $\mathrm{U}(\mathrm{VI})$ adsorption at fixed $\mathrm{pH}(\mathrm{pH} 7.5 \pm 0.3)$. These $\mathrm{U}(\mathrm{VI}) \mathrm{K}_{\mathrm{d}}$ values approach values as low as zero at total bicarbonate concentrations of equal to or greater than $12 \mathrm{meq} / \mathrm{L}$ as shown in Table 6.6. This concentration of total dissolved bicarbonate is less than the $\sim 40 \mathrm{meq} / \mathrm{L}$ inorganic carbon recommendation of very low $\mathrm{K}_{\mathrm{d}}$ values presented in Table 6.1 for the regions of the vadose zone affected by the composition of the glass leachate in the IDF PA.

The chemical composition predicted from the STORM code calculations for leachates that percolate out of the IDF are based on a detailed data set for glass leaching and a well-accepted kinetic dissolution model (see Pierce et al. 2004), but the subsequent interactions with the vadose zone sediments have not been characterized to the same extent. Up until this time, it was not realized that a more accurate assessment of the pore water composition would be important in selecting $\mathrm{K}_{\mathrm{d}}$ values for key contaminants such as U(VI). During the 2005 IDF PA activities, a more robust and accurate conceptual model will be developed to better address the chemical evolution of the glass leachate as it migrates through the sediments under the IDF.

One key reaction that will need to be added to the modeling calculations is the ion exchange of sodium that leaches from the glass with calcium and magnesium that naturally exist on the sediment exchange sites. The sediment contains a large source of calcium and magnesium ( $\sim 40$ to $70 \mathrm{meq} / \mathrm{kg}$ of sediment) that can react with the carbon dioxide equilibrated glass leachate and perhaps decrease the concentrations of dissolved inorganic carbon in response to calcite precipitation. Other calcium- and sodium-bearing secondary minerals may also form, such as those identified in laboratory experiments completed to investigate the pore fluid and mineral reactions resulting from contact of simulated tank leak fluids with Hanford sediments (see references noted in Section 3.8). Wan et al. (2004a, b) and references

Table 6.6. $\quad \mathrm{K}_{\mathrm{d}}$ Values ( $\left.\mathrm{mL} / \mathrm{g}\right)$ Measured for U(VI) by Serne et al. (2002a) as a Function of Dissolved Inorganic Carbon (Bicarbonate) Using Hanford Formation Coarse Sand and High IonicStrength Sodium-Bicarbonate-Sulfate Solution (constant ionic strength and $\mathrm{pH}=7.5 \pm 0.3$ )

\begin{tabular}{|c|c|c|c|c|}
\hline \multirow{2}{*}{$\begin{array}{c}\text { Initial Conc. } \\
\text { Dissolved U(VI) } \\
\text { (ppb) }\end{array}$} & \multirow{2}{*}{$\begin{array}{c}\text { Sample } \\
\text { Number }\end{array}$} & \multirow{2}{*}{$\begin{array}{l}\text { Total Dissolved } \\
\mathrm{HCO}_{3}^{-} \\
(\mathrm{mM})\end{array}$} & $\mathbf{K}_{\mathbf{d}}$ & $\begin{array}{c}\text { Average } \\
K_{d}\end{array}$ \\
\hline & & & \multicolumn{2}{|c|}{-------- (mL/g) -------- } \\
\hline \multirow{6}{*}{500} & "High I.S.-1 & 2.57 & 0.38 & \multirow{2}{*}{0.35} \\
\hline & High I.S.-2 & 2.47 & 0.32 & \\
\hline & High I.S.-3 & 6.46 & 0.08 & \multirow{2}{*}{0.06} \\
\hline & High I.S.-4 & 6.18 & 0.05 & \\
\hline & High I.S.-5 & 14.8 & $-0.47^{\mathrm{a}}$ & \multirow{2}{*}{$-0.49^{(a)}$} \\
\hline & High I.S.-6 & 12.3 & $-0.51^{\mathrm{a}}$ & \\
\hline \multirow{6}{*}{3,000} & High I.S.-7 & 2.66 & 0.22 & \multirow{2}{*}{0.20} \\
\hline & High I.S.-8 & 2.63 & 0.17 & \\
\hline & High I.S.-9 & 6.49 & 0.16 & \multirow{2}{*}{0.15} \\
\hline & High I.S.-10 & 5.83 & 0.14 & \\
\hline & High I.S.-11 & 12.42 & 0.03 & \multirow{2}{*}{0.05} \\
\hline & High I.S.-12 & 12.02 & 0.07 & \\
\hline \multicolumn{5}{|c|}{$\begin{array}{l}\text { (a) The concentration of adsorbed } \mathrm{U}(\mathrm{VI}) \text { used to calculate the } \mathrm{K}_{\mathrm{d}} \text { was determined by } \\
\text { subtracting the total amount of dissolved } \mathrm{U}(\mathrm{VI}) \text { from the initial concentrations of } \\
\text { dissolved } \mathrm{U}(\mathrm{VI}) \text {. For conditions of very low adsorption of } \mathrm{U}(\mathrm{VI}) \text {, negative } \mathrm{K}_{\mathrm{d}} \text { values } \\
\text { are therefore possible, and should be considered to equal } 0 \mathrm{~mL} / \mathrm{g} \text {. }\end{array}$} \\
\hline
\end{tabular}


cited therein showed that these ion exchange and precipitation reactions consume hydroxyl and thus decrease the solution $\mathrm{pH}$. The lowering of the $\mathrm{pH}$ and presence of more calcium and magnesium should, in turn, decrease the predicted concentration of total dissolved inorganic carbon in the pore fluids. Lower $\mathrm{pH}$ and lower concentrations of dissolved inorganic carbon in the pore fluids should result in U(VI) $\mathrm{K}_{\mathrm{d}}$ values that are larger than the values found in the studies by Serne et al. (2002a). Whether the $K_{d}$ values for U(VI) would increase to greater than $4 \mathrm{~mL} / \mathrm{g}$ (or even $1 \mathrm{~mL} / \mathrm{g}$ ) as found for ambient groundwater conditions (see tabulation of Hanford-specific $K_{d}$ values in Cantrell et al. [2003]) and under several of the leaking single-shell tanks (see discussion and references cited in Section 3.8) remains to be seen.

In Table 6.1 for uranium, we deviate from using the gravel correction convention of reducing the $\mathrm{K}_{\mathrm{d}}$ value measured for sand by $90 \%$ as we have done for all other contaminants. We justify this change based on the fact that dissolved inorganic carbon (carbonate and bicarbonate) and $\mathrm{pH}$ are the two dominant variables that have the greatest effect on U(VI) adsorption. Our laboratory testing with 300 Area sediment (see Serne et al. 2002) that contain some gravel shows that U(VI) sorption is not significantly reduced by the presence of gravel. We thus chose uranium $K_{d}$ values (see Table 6.1) for gravel zones the same as for sand zones. We feel this is a defensible position for dealing with this key riskdriving contaminant.

Additional laboratory experiments may be necessary to validate the lower $\mathrm{K}_{\mathrm{d}}$ values recommended for U(VI) (see Table 6.1) in the 2005 IDF PA calculations for the vadose zone regions impacted by the composition of the glass leachate and to better determine the effects of having $90 \%$ gravel present. Specific laboratory experiments would need to be conducted to determine 1) the composition of the glass leachate, especially its $\mathrm{pH}$ and concentration of total dissolved inorganic carbon; 2) the volume of vadose-zone sediment that will be affected by the composition of the glass leachate; 3) the U(VI) $\mathrm{K}_{d}$ value determined using IDF-specific vadose-zone sediments and the best estimate of the compositions of the glass leachate; and 4) the effects of having predominantly gravel-sized particles present in specific strata.

\section{3 $K_{d}$ Values for ${ }^{79}$ Se}

In 1998, little Hanford-specific data existed for the adsorption properties of selenium (as selenate or selenite). For the 1998 ILAW PA, it was, therefore, recommended that the $\mathrm{K}_{\mathrm{d}}$ values for ${ }^{79} \mathrm{Se}$ be set at $0 \mathrm{~mL} / \mathrm{g}$. Between 1998 and 2001, batch $\mathrm{K}_{\mathrm{d}}$ studies (Kaplan et al. 1998c) were completed using several Hanford sediments, including IDF borehole 299-E17-21. The solution used in these measurements was uncontaminated groundwater, and the sediments were dominated by sand-sized particles. Kaplan et al. (1998b) also studied the adsorption of ${ }^{75} \mathrm{Se}$, as a surrogate for ${ }^{79} \mathrm{Se}$, from Hanford groundwaters with $\mathrm{pH}$ values that had been adjusted to higher than normal values. The measurements suggest that some significant adsorption of selenate would be expected for both groundwater and higher $\mathrm{pH}$ solutions. Thus for the 2001 ILAW PA, the "most probable" $\mathrm{K}_{\mathrm{d}}$ value for selenium was chosen as $4 \mathrm{~mL} / \mathrm{g}$.

More recent work by Kaplan et al. (2003) indicates that selenate adsorption to Hanford sediments is nil for highly alkaline solutions. This is consistent with geochemical principles (see discussion in EPA 1999a and references therein) that suggest that anionic species, such as selenite and selenate, should show reduced sorption at greater-than-neutral $\mathrm{pH}$ conditions onto any sediment containing minerals with variably charged adsorption surface sites, such as iron and aluminum hydrous oxide minerals and particle coatings. 
Um and Serne ${ }^{(a)}$ used an uncontaminated groundwater and a simulated glass leachate based on the composition for the long-term, steady-state chemical composition of glass leachate and vadose zone pore water predicted by the STORM code for the 2001 ILAW PA (See Table 6.2) to study selenate adsorption onto three samples of Hanford formation sediments from another IDF borehole (299-E24-21 [ILAW borehole \#2 - C3177]). The $\mathrm{K}_{\mathrm{d}}$ values measured by Um and Serne for selenate are described in Section 3.5.3. These tests also contained a trace amount of stable selenate (few parts per billion) that was not present in the earlier studies by Kaplan et al. (1998b, c). Because these earlier studies used only the carrier-free ${ }^{75} \mathrm{Se}$ isotope (which essentially means the mass of selenium present was infinitesimal), we later became concerned that the $\mathrm{K}_{\mathrm{d}}$ results might be biased high by not having some selenium mass present. The most recent results by Um and Serne ${ }^{(a)}$ corroborate the selenium $\mathrm{K}_{\mathrm{d}}$ values obtained by Kaplan et al. (1998c) for natural groundwater and Hanford sediments, but do indicate that selenium $\mathrm{K}_{\mathrm{d}}$ values for more alkaline solutions, including simulated glass leachate, are considerably smaller than $4 \mathrm{~mL} / \mathrm{g}$, the value recommended in 2001. Thus, for the 2005 IDF PA, we changed (decreased) the $\mathrm{K}_{\mathrm{d}}$ value for ${ }^{79} \mathrm{Se}$ for the chemically impacted zones, where the glass leachate forces the pore fluid $\mathrm{pH}$ to be elevated above background. No changes were made to the $\mathrm{K}_{\mathrm{d}}$ values for selenium for the near-field concrete-impacted zone. During preparation of this data package, we determined that for the 2001 data package, the recommended $\mathrm{K}_{\mathrm{d}}$ values for the chemically impacted gravel zone had inadvertently not been reduced by the factor of 10 to account for the assumed $90 \%$ gravel content. Thus there is a change (correction) to the recommended $2005 \mathrm{~K}_{\mathrm{d}}$ values for this zone.

Um and Serne ${ }^{(a)}$ measured the $\mathrm{K}_{\mathrm{d}}$ for selenate in simulated glass leachate onto IDF borehole sediments (see Section 3.5.3) and consistently found non-zero $K_{d}$ values for selenium for six tests. Their values for the simulated glass leachate ranged from 1 to $3 \mathrm{~mL} / \mathrm{g}$ with good precision. At long time periods, we assume that glass weathering products will adsorb some selenium. Therefore we recommend that a nonzero $\mathrm{K}_{\mathrm{d}}$ is appropriate and chose a $\mathrm{K}_{\mathrm{d}}$ value of $1 \mathrm{~mL} / \mathrm{g}$ for selenate for the long-term near-field zone. Based on the results of Um and Serne, we also are more confident that the "most probable" $\mathrm{K}_{\mathrm{d}}$ for ${ }^{79} \mathrm{Se}$ for the chemically unaltered pore water/groundwater fluid can be increased from 4 to $7 \mathrm{~mL} / \mathrm{g}$ (see Table 6.1). We have not tested selenium adsorption on Hanford sediments that contain significant quantities of gravel-sized material. We therefore rely on the conservative gravel-correction factor (see Equation 2.6) and assume that the gravel-dominated sequence at the bottom of the vadose zone and at the upper unconfined aquifer has $90 \%$ gravel. This effectively reduces the recommended $\mathrm{K}_{\mathrm{d}}$ values in gravel zones by a factor of 10 as listed in Table 6.1. To build in further conservatism, the chemically impacted gravel values were reduced further. It is likely that the chemically impacted sand zone controls the travel time of selenium in the PA calculations.

(a) Um W and RJ Serne. 2004. "Sorption and Transport Behavior of Radionuclides in the Proposed Low-Level Radioactive Waste Disposal Facility at the Hanford Site, Washington." Submitted to Radiochimica Acta. 


\subsection{References}

Al Mahamid I, CF Novak, KA Becraft, SA Carpenter, and N Hakem. 1998. "Solubility of Np(V) in $\mathrm{K}-\mathrm{Cl}-\mathrm{CO}_{3}$ and $\mathrm{Na}-\mathrm{K}-\mathrm{Cl}-\mathrm{CO}_{3}$ solutions to high concentrations: Measurements and thermodynamic model predictions.” Radiochim. Acta 81:93-101.

Allard B. 1984. "Mechanisms for the interaction of americium(III) and neptunium(V) with geologic media." Scientific Basis for Nuclear Waste Management VII, GL McVay (ed.), pp. 899-906, Materials Research Society Symposium Proceedings, Vol. 26, North-Holland, New York.

Allard B, B Torstenfelt, and $\mathrm{K}$ Andersson. 1981. "Sorption studies of $\mathrm{H}^{14} \mathrm{CO}_{3}$ - on some geologic media and concrete.” Scientific Basis for Nuclear Waste Management III, pp. 465-472, JG Moore (ed.), Materials Research Society Symposium Proceedings, Vol. 3, Plenum Press, New York.

Allard B, L Allicin, S Hoglund, and K Anderson. 1984. Sorption of Cs, I and Actinides in Concrete Systems. KGS 84-15, Swedish Nuclear Fuel and Waste Management Co., Stockholm.

Ames LL and D Rai. 1978. Radionuclide Interactions with Soil and Rock Media. Volume 1: Processes Influencing Radionuclide Mobility and Retention, Element Chemistry and Geochemistry, and Conclusions and Evaluations. EPA 520/6-78-007-a, U.S. Environmental Protection Agency, Las Vegas, NV.

Ames LL and RJ Serne. 1991. Compilation of Data to Estimate Groundwater Migration Potential for Constituents in Active Liquid Discharges at the Hanford Site. PNL-7660. Pacific Northwest Laboratory, Richland, WA.

Ames LL, JE McGarrah, BA Walker, and PF Salter. 1982. "Sorption of uranium and cesium by Hanford basalts and associated secondary smectites." Chem. Geol. 35:205-225.

Andreyev PF and AP Chumachenko. 1964. "Reduction of uranium by natural organic substances." Geochem. Int. 1:3-7.

Angus MJ and FP Glasser. 1985. "The chemical environment in cement matrices." Scientific Basis for Nuclear Waste Management IX, LO Werme (ed.), pp. 547-556, Material Research Society Symposium Proceedings, Vol. 50, Material Research Society, Pittsburgh, PA.

Atkinson A and AK Nickerson. 1988. "Diffusion and sorption of cesium, strontium, and iodine in watersaturated cement.” Nuclear Tech. 81:100-113.

Artiola J and WH Fuller. 1979. "Effect of crushed limestone barriers on chromium attenuation in soils." J. Environ. Quality 8:503-510.

Bacon DH, MD White, and BP McGrail. 2004. Subsurface Transport over Reactive Multiphases (STORM): A Parallel, Coupled, Nonisothermal Multiphase Flow, Reactive Transport, and Porous Medium Alteration Simulator, Version 3.0. User's Guide. PNNL-14783, Pacific Northwest National Laboratory, Richland, WA.

Baes CF, Jr, and RE Mesmer. 1976. The Hydrolysis of Cations. John Wiley and Sons, New York. 
Ball JW and DK Nordstrom. 1998. "Critical evaluation and selection of standard state thermodynamic properties for chromium metal and its aqueous ions, hydrolysis species, oxides, and hydroxides."

J. Chem. Engin. Data 43:895-918.

Barnett MO, PM Jardine, and SC Brooks. 2002. "U(VI) adsorption to heterogeneous subsurface media: Application of a surface complexation model.” Envir. Sci. Tech 36: 937-942.

Barney GS. 1978. Variables Affecting Sorption and Transport of Radionuclides in Hanford Subsoils. RHO-SA-87, Rockwell Hanford Operations, Richland, WA.

Baron D and CD Palmer. 1996. "Solubility of $\mathrm{KFe}_{3}\left(\mathrm{CrO}_{4}\right)_{2}(\mathrm{OH})_{6}$ at 4 to $35^{\circ} \mathrm{C}$." Geochim. Cosmo. Acta 60:3815-3824.

Baron D, CD Palmer, and JT Stanley. 1996. "Identification of two iron-chromate precipitates in a Cr(VI)-contaminated soil.” Environ. Sci. Tech. 30:964-968.

Bartlett RJ and JM Kimble. 1976. "Behavior of chromium in soils. I. Trivalent forms." J. Environ. Quality 5:379-383.

Bayliss S, FT Ewart, RM Howse, SA Lane, NJ Pilkington, JL Smith-Briggs, and SJ Williams. 1989. "The solubility and sorption of radium and tin in a cementitious near-field environment." Scientific Basis for Nuclear Waste Management XII, W Lutze and RC Ewing (eds.), pp. 879-885, Vol. 127. Materials Research Society, Pittsburgh, PA.

Bayliss S, A Haworth, R McCrohon, AD Moreton, P Oliver, NJ Pilkington, AJ Smith, and JL SmithBriggs. 1991. "Radioelement behavior in a cementitious environment." Scientific Basis for Nuclear Waste Management XV, CG Sombret (ed.), pp. 641-648, Vol. 257. Materials Research Society, Pittsburgh, PA.

Beasley TM and HV Lorz. 1984. "A review of the biological and geochemical behavior of technetium in the marine environment." Technetium in the Environment, G Desment and C Myttenaere (eds.), pp. 197-216. Elsevier Applied Science Publishers, Amsterdam.

Benjamin MM and NS Bloom. 1981. "Effects of strong binding of anionic adsorbates on adsorption of trace metals on amorphous iron oxyhydroxide." Adsorption from Aqueous Solutions, PH Tewari (ed.), pp. 41-60. Plenum Press, New York.

Benson DW. 1961. Mineral Adsorption of Radionuclides in Reactor Effluent. HW-69225, General Electric Company, Hanford Atomic Products Operations, Richland, WA.

Berner UR. 1992. "Evolution of pore water chemistry during degradation of cement in a radioactive waste repository." Waste Management, 12:201-219.

Bernhard G, G Geipel, V Brendler, and H Nitsche. 1996. "Speciation in uranium in seepage waters of a mine tailing pile studied by time resolved laser-induced fluorescence spectroscopy." Radiochim. Acta 74:87-91. 
Bernhard G, G Geipel, T Reich, V Brendler, S Amayri, and H Nitsche. 2001. "Uranyl(VI) carbonate complex formation: validation of the $\mathrm{Ca}_{2} \mathrm{UO}_{2}\left(\mathrm{CO}_{3}\right)_{3}$ (aq.) species." Radiochim. Acta 89:511-518.

Bertsch PM, DB Hunter, SR Sutton, S Bajt, and ML Rivers. 1994. "In situ chemical speciation of uranium in soils and sediments by micro x-ray absorption spectroscopy." Envir. Sci. Tech. 28:980-984.

Bickmore BR, KL Nagy, JS Young, and JW Drexler. 2001. "Nitrate-cancrinite precipitation on quartz sand in simulated Hanford tank solutions." Envir. Sci. Tech. 35:4481-4486.

Birch LD and R Bachofen. 1990. "Effects of microorganisms on the environmental mobility of radionuclides.” Soil Biochemistry: Volume 6, JM Bollag and G Stotzky (eds.), pp. 101-124. Marcel Dekker, Inc., New York.

Blowes DW and CJ Ptacek. June 1992. "Geochemical remediation of groundwater by permeable reactive walls: removal of chromate by reaction with iron-bearing solids." Proceedings of the Subsurface Restoration Conference, pp. 214-216. Rice University Press, Houston.

Boggs S, Jr, D Livermore, and MG Seitz. 1985. Humic Substances in Natural Waters and Their Complexation with Trace Metals and Radionuclides: A Review. ANL-84-78, Argonne National Laboratory, Argonne, IL.

Bondietti EA and CW Francis. 1979. "Geologic migration potentials of technetium-99 and neptunium-237.” Science 203:1337-1340.

Borovec Z, B Kribek, and V Tolar. 1979. "Sorption of uranyl by humic acids.” Chem. Geol. 27:39-46.

Bouwer H. 1991. "Simple derivation of the retardation equation and application to preferential flow and macrodispersion." Ground Water 29:41-46.

Bowen HJN. 1966. Trace Elements in Biochemistry. Academic Press, London.

Box GEP and DW Behnken. 1960. "Some new three-level designs for the study of quantitative variables." Techometrics 2:455-475.

Bradbury MH and FA Sarott. 1995. Sorption Databases for the Cementitious Near-Field of a L/ILW Repository for Performance Assessment. PSI Bericht Nr. 95-06, Paul Scherrer Institute, Wurenligen and Villigen, Switzerland.

Brady PV and MW Kozak. 1995. "Geochemical engineering of low level radioactive waste in cementitious environments." Waste Management 15:293-301.

Brodda BG. 1988. "Leachability of technetium from concrete." The Science of the Total Environment 69:319-345.

Brooks SC, JK Fredrickson, SL Carroll, DW Kennedy, JM Zachara, AE Plymale, SD Kelly, KM Kemner, and S Fendorf. 2003. "Inhibition of bacterial U(VI) reduction by calcium." Environ. Sci. Tech. $37: 1850-1858$. 
Buck EC, NR Brown, and NL Dietz. 1994. "Distribution of uranium-bearing phases in soils from Fernald." Scientific Basis for Nuclear Waste Management XVII, A Barkatt and RA Van Konynenburg (eds.), pp. 437-444, Volume 333. Materials Research Society, Pittsburgh, PA.

Buck EC, NR Brown, and NL Dietz. 1996. "Contaminant uranium phases and leaching at the Fernald Site in Ohio." Envir. Sci. Tech. 30:81-88.

Burns PC and R Finch (eds.). 1999. Reviews in Mineralogy. Vol. 38. Mineralogy, Geochemistry and the Environment. Mineralogical Society of America, Washington, DC.

Cantrell KJ, DI Kaplan, and TW Wietsma. 1995. "Zero-valent iron for the in situ remediation of selected metals in groundwater." J. Haz. Mat. 42:201-212.

Cantrell KJ, RJ Serne, and GV Last. 2002. Applicability of the Linear Sorption Isotherm Model to Represent Contaminant Transport Processes in Site-Wide Performance Assessments. CP-17089 Rev. 0 (PNNL-14576), prepared for Fluor Hanford, Inc. by Pacific Northwest National Laboratory, Richland, WA.

Cantrell KJ, RJ Serne, and GV Last. 2003. Hanford Contaminant Distribution Coefficient Database and Users Guide. PNNL-13895, Rev. 1, Pacific Northwest National Laboratory, Richland, WA.

Catalano JG, JM Zachara, and GE Brown, Jr. 2002. "X-ray spectroscopic investigation of the distribution and speciation of uranium in samples from the BX-102 borehole." Appendix D (D.3.3), Digest of Science and Technology Program Evaluations, in Field Investigation Report for Waste Management Area B-BX-BY. Volume 2, Appendices, AJ Knepp, pp. D-140 to D-160. RPP-10098, CH2M HILL Hanford Group, Inc., Richland, WA.

Catalano JG, SM Heald, JM Zachara, and GE Brown, Jr. 2004. "Spectroscopic and diffraction study of uranium speciation in contaminated vadose zone sediments from the Hanford Site, Washington State." Environ. Sci. Tech. 387:2822-2828.

Cataldo DA, RE Wildung, and TR Garland. 1978. "Technetium accumulation, fate, and behavior in plants." Environmental Cycling Processes, DC Adriano and IL Brisbin, (eds.) pp.207-220, University of Georgia, Athens, GA.

Chasteen TG. 1998. "Volatile chemical species of selenium." Environmental Chemistry of Selenium, WT Frankenberger, Jr. and RA Engberg (eds.), pp. 589-612. Marcel Dekker, Inc., New York.

Chisholm-Brause C, SD Conradson, CT Buscher, PG Eller, and DE Morris. 1994. "Speciation of uranyl sorbed at multiple binding sites on montmorillonite." Geochim. Cosmo. Acta 58(17):3625-3631.

Chorover J, SK Choi, MK Amistadi, KG Karthikeyan, G Crosson, and KT Mueller. 2003. "Linking cesium and strontium uptake to kaolinite weathering in simulated tank waste leachate." Environ. Sci. Tech. 37:2200-2208. 
Christensen JN, PE Dresel, ME Conrad, K Maher, and DJ DePaolo. 2004. "Identifying the sources of subsurface contamination at the Hanford Site in Washington using high-precision uranium isotopic measurements." Environ. Sci. Tech. 38:3330-3337.

Cochran GW and GM Cox. 1957. Experimental Design. $2^{\text {nd }}$ Edition, Wiley and Sons, New York.

Cotton FA and G Wilkinson. 1972. Advanced Inorganic Chemistry, A Comprehensive Text, $3^{\text {rd }}$ Edition. Wiley and Sons, New York.

Coughtrey PJ, D Jackson, and MC Thorne. 1983. Radionuclide Distribution and Transport in Terrestrial and Aquatic Ecosystems. A Critical Review of Data. AA Balkema, Rotterdam.

Coughtrey PJ, D Jackson, CH Jones, P Kane, and MC Thorne. 1984. Radionuclide Distribution and Transport in Terrestrial and Aquatic Ecosystems. A Critical Review of Data. AA Balkema, Boston.

Curtis GP, P Fox, M Kohler, and JA Davis. 2004. "Comparison of in situ uranium $\mathrm{K}_{\mathrm{D}}$ values with a laboratory determined surface complexation model." Appl. Geochem. 19:1643-1653.

Davies OL. 1954. Design and Analysis of Industrial Experiments. Hafner, New York.

Davis 2001 (cited in text)

Davis JA and GP Curtis. 2003. Application of Surface Complexation Modeling to Describe Uranium(VI) Adsorption and Retardation at the Uranium Mill Tailings Site at Naturita, Colorado. NUREG/CR-6820, prepared by U.S. Geological Survey foe U.S. Nuclear Regulatory Commission, Washington, DC.

Davis JA and JO Leckie. 1980. "Surface ionization and complexation at the oxide/water interface. 3. Adsorption of anions." J. Colloid Interface Science, 74:32-43.

Davis JA, JA Coston, DB Kent, and CC Fuller. 1998. "Application of the surface complexation concept to complex mineral assemblages." Environ. Sci. Tech. 32:2820-2828.

de Haan FAM and PJ Zwerman. 1978. "Pollution of soil.” Soil Chemistry. A. Basic Elements, GH Bolt and MGM Bruggenwert (eds.), pp. 192-271. Elsevier Scientific Publishing Company, Developments in Soil Science 5A, New York.

Delegard CH and GS Barney. 1983. Effects of Hanford High-Level Waste Components on Sorption of Cobalt, Strontium, Neptunium, Plutonium, and Americium of Hanford Sediments. RHO-RE-ST-1 P, Rockwell Hanford Operations, Richland, WA.

Delegard CH, RL Weiss, RT Kimura, AG Law, and RC Routson. 1986. "Characterization and anion exchange removal of uranium from Hanford ground water." Waste Management'86, Volume 1, RG Post (ed.), pp. 545-550. Arizona Board of Regents, AZ.

DOE, see U.S. Department of Energy

Doner HE and WC Lynn. 1977. "Carbonate, halide, sulfate, and sulfide minerals." Minerals in Soil Environments, JB Dixon and SB Weed (eds.), pp. 75-98. Soil Society of America, Madison, WI. 
Eary LE and D Rai. 1987. "Kinetics of chromium(III) oxidation to chromium(VI) by reaction with manganese dioxide." Environ. Sci. Tech. 21:1187-1193.

Eary LE and D Rai. 1989. "Kinetics of chromate reduction by ferrous ions derived from hematite and biotite at $25^{\circ}$ C." Amer. J. Sci. 289:180-213.

Efurd D, W Runde, JC Banar, DR Janecky, JP Kaszuba, PD Palmer, FR Roensch, and CD Tait. 1998. "Neptunium and plutonium solubilities in a Yucca Mountain groundwater." Applied Geochem. 32:3893-3900.

Elrashidi MA, DC Adriano, and WL Lindsay. 1989. "Solubility, speciation, and transformations of selenium in soils." Selenium in Agriculture and the Environment, LW Jacobs (ed.), pp. 51-63, SSSA Special Publication Number 23, Soil Science Society of America, Inc., Madison, WI.

EPA, see U.S. Environmental Protection Agency.

Eriksen TE, P Ndalamba, J Bruno, and M Caceci. 1992. "The solubility of $\mathrm{TcO}_{2} \mathrm{AH}_{2} \mathrm{O}$ in neutral to alkaline solutions under constant $\mathrm{p}_{\mathrm{CO} 2 .}$ " Radiochim. Acta 58/59:67-70.

Ewart F, S Pugh, S Wisbey, and D Woodwark. 1988. Chemical and Microbiological Effects in the NearField: Current Status. Report NSS/G103, U.K. Nirex Ltd., Harwell, UK.

Ewart FT, JL Smith-Briggs, HP Thomason, and SJ Williams. 1992. "The solubility of actinides in a cementitious near-field environment." Waste Management, 12:241-252.

Falck WE. 1991. CHEMVAL Project. Critical Evaluation of the CHEMVAL Thermodynamic Database with Respect to its Contents and Relevance to Radioactive Waste Disposal at Sellafield and Dounreay. DOE/HMIP/RR/92.064, Department of Environment, Her Majesty's Stationary Office, London.

Fayer MJ and JE Szecsody. 2004. Recharge Data Package for the Integrated Disposal Facility 2005 Performance Assessment. PNNL-14744, Pacific Northwest National Laboratory, Richland, WA.

Finch R and T Murakami. 1999. "Systematics and paragenesis of uranium minerals." Reviews in Mineralogy. Vol. 38. Uranium: Mineralogy, Geochemistry and the Environment, PC Burns and R Finch (eds.), pp. 91-179. Mineralogical Society of America, Washington, DC.

Flury M, JB Mathison, and JB Harsh. 2002. "In situ mobilization of colloids and transport of cesium in Hanford sediments.” Environ. Sci. Tech. 36:5335-5341.

Flury M, S Czigány, G Chen, and JB Harsh. 2004. "Cesium migration in saturated silica sand and Hanford sediments as impacted by ionic strength.” J. Contam. Hydrol. 71:111-126.

Fredrickson JK, HM Kostandarithes, SW Li, AE Plymale, and MJ Daly. 2000. "Reduction of Fe(III), Cr(VI), U(VI), and Tc(VII) by Deinococcus radiodurans R1.” Appl. Environ. Microbio. 66:2006-2011.

Fredrickson JK, JM Zachara, DL Balkwill, D Kennedy, SW Li, HM Kostandarithes, MJ Daly, MF Romine, and FJ Brockman. 2004. "Geomicrobiology of high-level nuclear waste-contaminated vadose sediments at the Hanford Site, Washington State.” Appl. Environ. Microbiology 70:4230-4241. 
Frondel C. 1958. Systematic Mineralogy of Uranium and Thorium. Geological Survey Bulletin 1064. U.S. Geological Survey, Washington, DC.

Frost RR and RA Griffin. 1977. "Effect of $\mathrm{pH}$ on adsorption of copper, zinc, and cadmium from landfill leachate by clay minerals." J. Environ. Sci. Health, A12:139-156.

Fruchter JS, CR Cole, MD Williams, VR Vermeul, JE Amonette, JE Szecsody JD Istok, and MD Humphrey. 2000. "Creation of a subsurface permeable treatment zone for aqueous chromate contamination using in situ redox manipulation." Ground Water Monitoring. Remediation 20: 66-77.

Gamerdinger AP, DI Kaplan, and CT Resch. 1998. Uranium (VI) Sorption and Transport in Unsaturated, Subsurface Hanford Site Sediments - Effect of Moisture Content and Sediment Texture. PNNL-11975, Pacific Northwest National Laboratory, Richland, WA.

Gamerdinger AP, DI Kaplan, DM Wellman, and RJ Serne. 2001. "Two-region flow and rate-limited sorption of uranium (VI) during transport in an unsaturated silt loam." Water Resources Res. 37:3147-3153.

Garnier JM. 1985. "Retardation of dissolved radiocarbon through a carbonated matrix." Geochim. Cosmo. Acta, 49:683-693.

Garrels RM and CL Christ. 1965. Solutions, Minerals, and Equilibria. Freeman, Cooper and Co., San Francisco.

Geering HR, EE Cary, LHP Jones, and WH Allaway. 1968. "Solubility and redox criteria for the possible forms of selenium in soils." Soil Sci. Soc. Am. Proc. 32:35-40.

Gilliam TM, RD Spence, BS Evans-Brown, IL Morgan, JL Shoemaker, and WD Bostick. 1989. "Performance testing of blast furnace slag for immobilization of technetium in grout." Nuclear and Hazardous Waste Management Spectrum '88, pp. 109-111. American Nuclear Society, La Grange Park, IL.

Girvin DC, LL Ames, AP Schwab, and JE McGarrah. 1991. "Neptunium adsorption on synthetic amorphous iron oxyhydroxide.” J. Colloid Interface Sci. 141:67-78.

Grenthe I, J Fuger, RJM Konings, RJ Lemire, AB Muller, C Nguyen-Trung, and H Wanner. 1992. Chemical Thermodynamics, Volume 1: Chemical Thermodynamics of Uranium. North-Holland, Elsevier New York.

Griffin RA, AK Au, and RR Frost. 1977. "Effect of $\mathrm{pH}$ on adsorption of chromium from landfillleachate by clay minerals." J. Environ. Sci. Health, 12:431-449.

Gu B and RK Schulz. 1991. Anion Retention in Soil: Possible Application to Reduce Migration of Buried Technetium and Iodine. NUREG/CR-5464, prepared by the University of California at Berkeley for the U.S. Nuclear Regulatory Commission, Washington, DC. 
Guillaumont R, T Fanghänel, J Fuger, I Grenthe, V Neck, DA Palmer, and ML Rand. 2003. Chemical Thermodynamics, Volume 5. Update on the Chemical Thermodynamics of Uranium, Neptunium, Plutonium, Americium, and Technetium. Elsevier, New York.

Guo L, WT Frankenberger, Jr, and WA Jury. 1999. "Adsorption and degradation of dimethyl selenide in soil." Environ. Sci. Tech. 33:2934-2938.

Hakanen M and A Lindberg. 1991. "Sorption of neptunium under oxidizing and reducing groundwater conditions." Radiochim. Acta 52/53:147-151.

Hamby AA and G Gissel-Nelson. 1977. "Fixation of selenium by clay minerals and iron oxides." $Z$. Pflanzenernaehr. Bodenkd. 140,1:63-70.

Hanke K, B Jahrling, and KJ Lieser. 1986. "Properties and solubility of technetium dioxide." Technetium in the Environment, G Desment and C Myttenaere (eds.), pp. 179-187. Elsevier Applied Science Publishers, Amsterdam.

Hartman MJ and PE Dresel (eds.). 1997. Hanford Site Groundwater Monitoring for Fiscal Year 1996. PNNL-11470, Pacific Northwest National Laboratory, Richland, WA.

Hartman MJ, LF Morasch, and WD Webber (eds.). 2004. Hanford Site Groundwater Monitoring for Fiscal Year 2003. PNNL 14548, Pacific Northwest National Laboratory, Richland, WA.

Hem JD. 1977. "Reactions of metal ions at surfaces of hydrous iron oxide." Geochim. Cosmo. Acta, 41:527-538.

Hem JD. 1986. Study and Interpretation of Chemical Characterizations of Natural Water. WaterSupply Paper 2254, U.S. Geological Survey, Alexandria, VA.

Hietanen R, T Jaakkola, and J Miettinent. 1985. "Sorption of cesium, strontium, iodine, and carbon in concrete and sand." Scientific Basis for Nuclear Waste Management VIII, CM Jantzen, JA Stone, and RC Ewing (eds.), pp. 891-898, Vol. 44. Materials Research Society, Pittsburgh, PA.

Hietanen R, E Kamarainen, and M Alaluusua. 1984. Sorption of Strontium, Cesium, Nickel, Iodine and Carbon in Concrete. YJT-84-04, Nuclear Waste Commission of the Finnish Power Companies, Helsinki.

Hingston FJ, AM Posner, and JP Quirk. 1972. "Anion adsorption by goethite and gibbsite. The role of the proton in determining adsorption envelopes." J. Soil Sci. 23:177-192.

Hingston FJ, AM Posner, and JP Quirk. 1971. "Competitive adsorption of negatively charged ligands on oxide surfaces." Disc. Faraday Soc, 52:234-342.

Hingston FJ, AM Posner, and JP Quirk. 1968. “Adsorption of selenite by goethite.” Adv. Chem. Series, 79:82-90.

Hoglund S, L Eliasson, B Allard, K Anderson, and B Torstenfelt. 1985. "Sorption of some fission products and actinides in concrete systems." Scientific Basis for Nuclear Waste Management IX, LO Werme (ed.), pp. 683-690, Vol. 50. Materials Research Society, Pittsburgh, PA. 
Hollander M and DA Wolfe. 1973. Nonparametric Statistical Methods. Wiley and Sons, New York.

Horton DG, HT Schaef, RJ Serne, CF Brown, MM Valenta, TS Vickerman, IV Kutnyakov, SR Baum, KN Geiszler, and KE Parker. 2003. Geochemistry of Samples from Borehole C3177 (299-W24-21). PNNL-14289, Pacific Northwest National Laboratory, Richland, WA.

Hsi C and L Langmuir. 1985. "Adsorption of uranyl onto ferric oxyhydroxides: Application of the surface complexation site-binding model." Geochem. Cosmo. Acta, 49:1931-1941.

Hughes MA and FJC Rossotti. 1987. A Review of Some Aspects of the Solution Chemistry of Technetium. AERE-R 12820, University of Oxford, UK.

Hunter DB and PM Bertsch. 1998. "In situ examination of uranium contaminated soil particles by micro-X-ray absorption and micro-fluorescence spectroscopies." J. Radioanal. Nucl. Chem. 234:237-242.

Idiz EF, D Carlisle, and IR Kaplan. 1986. "Interaction between organic matter and trace metals in a uranium rich bog, Kern County, California, U.S.A.” Appl. Geochem. 1:573-590.

Itagaki H, S Tanaka, and M Yamawaki. 1991. "Neptunium chemical behavior in underground environments using ultrafiltration and centrifugation.” Radiochim. Acta 52/53:91-94.

Jenne EA (ed.). 1998. Metal Adsorption by Geomedia. Academic Press, San Diego.

John MK, WMN Saunders, and JH Watkinson. 1976. "Selenium adsorption by New Zealand soils. I. Relative adsorption of selenite by representative soils and relationship to soil properties." J. Agr. Res. 19:143-151.

Johnson CA and AG Xyla. 1991. "The oxidation of chromium(III) to chromium(VI) on the surface of manganite ( $\gamma-\mathrm{MnOOH}) . "$ Geochim. Cosmo. Acta 55:2861-2866.

Johnson KS. 1994. “Iodine.” Industrial Minerals and Rocks, DC Carr (ed.), pp. 583-588. Society for Mining, Metallurgy, and Exploration, Littleton, CO.

Johnston HM and DJ Wilmot. 1992. "Sorption and diffusion studies in cementitious grouts." Waste Management 12:289-297.

Kalmykov SN and GR Choppin. 2000. "Mixed $\mathrm{Ca}^{2+} / \mathrm{UO}_{2}{ }^{2+} / \mathrm{CO}_{3}{ }^{2-}$ complex formation at different ionic strengths." Radiochim. Acta 88:603-606.

Kaplan DI and RJ Serne. 1995. Distribution Coefficient Values Describing Iodine, Neptunium, Selenium, Technetium, and Uranium Sorption to Hanford Sediments. PNL-10379 Sup. 1, Pacific Northwest Laboratory, Richland, WA.

Kaplan DI and RJ Serne. 2000. Geochemical Data Package for the Hanford Immobilized Low-Activity Tank Waste Performance Assessment (ILAW PA). PNNL-13037 Rev. 1, Pacific Northwest National Laboratory, Richland, WA. 
Kaplan DI, RJ Serne, and MG Piepho. 1995. Geochemical Factors Affecting Radionuclide Transport Through Near and Far Field at a Low-Level Waste Disposal Site. PNL-10379, Pacific Northwest Laboratory, Richland, WA.

Kaplan DI, RJ Serne, AT Owen, JA Conca, TW Wietsma, and TL Gervais. 1996. Radionuclide Adsorption Distribution Coefficients Measured in Hanford Sediments for the Low Level Waste Performance Assessment Project. PNNL-11385, Pacific Northwest National Laboratory, Richland, WA.

Kaplan DI, TL Gervais, and KM Krupka. 1998a. "Uranium(VI) sorption to sediments under high pH and ionic strength conditions." Radiochim. Acta 80:201-211.

Kaplan DI, KE Parker, and RD Orr. 1998b. Effects of High-pH and High-Ionic Strength Groundwater on Iodide, Pertechnetate, and Selenate Sorption to Hanford Sediments. PNNL-11964, Pacific Northwest National Laboratory, Richland, WA.

Kaplan DI, KE Parker, and IV Kutnyakov. 1998c. Radionuclide Distribution Coefficients for Sediments Collected from Borehole 299-E17-21: Final Report for Subtask 1a. PNNL-11996, Pacific Northwest National Laboratory, Richland, WA.

Kaplan DI, RJ Serne, KE Parker, and IV Kutnyakov. 1999. "Radionuclide sorption to sediment minerals." Scientific Basis for Nuclear Waste Management XXII, DJ Wronkiewicz and JH Lee, pp. 1059-1065, Vol. 556. Materials Research Society, Pittsburgh, PA.

Kaplan DI, RJ Serne, KE Parker, and IV Kutnyakov. 2000a. "Iodide sorption to subsurface sediments and illitic minerals." Environ. Sci. Tech. 34:399-405.

Kaplan DI, IV Kutnyakov, AP Gamerdinger, RJ Serne, and KE Parker. 2000b. "Gravel corrected $\mathrm{K}_{\mathrm{d}}$ values." Ground Water 38(6):851-857.

Kaplan DI, RJ Serne, HT Schaef, CW Lindenmeier, KE Parker, AT Owen, DE McCready, and JS Young. 2003. The Influence of Glass Leachate on the Hydraulic, Physical, Mineralogical and Sorptive Properties of Hanford Sediment. PNNL-14325, Pacific Northwest National Laboratory, Richland, WA.

Kato S and Y Yanase. 1993. Distribution Coefficients of Radionuclides in Concrete Waste for Coastal Soil and Concrete Powder. JAERI-M 93-113, Japan Atomic Energy Research Institute, Ibaraki-ken, Japan.

Keller C. 1971. The Chemistry of the Transuranium Elements. Vol. 3. Kernchemie in Einzeldarstellunge, Verlag Chemie GmbH, Munchen, Germany.

Kent DB, VS. Tripathi, NB Ball, JO Leckie, and MD Siegel. 1988. Surface-Complexation Modeling of Radionuclide Adsorption in Subsurface Environments. NUREG/CR-4807 (SAND86-7175), U.S. Nuclear Regulatory Commission, Washington, DC.

Khaleel R. 1999. Far-Field Hydrology Data Package for Immobilized Low-Activity Tank Waste Performance Assessment. HNF-4769 Rev. 1, Fluor Daniel Northwest, Inc., Richland, WA. 
Khaleel R. 2004. Far-Field Hydrology Data Package for Integrated Disposal Facility Performance Assessment. RPP-20621 Rev. 0, CH2M HILL Hanford Group, Inc., Richland, WA.

Kincaid CT, PW Eslinger, WE Nichols, AL Bunn, RW Bryce, TB Miley, MC Richmond, SF Snyder, and RL Aaberg. 2000. Groundwater/Vadose Zone Integration Project, System Assessment Capability (Revision 0), Assessment Description, Requirements, Software Design, and Test Plan. BHI-01365, Bechtel Hanford, Inc., Richland, WA.

Knepp AJ. 2002. Field Investigation Report for Waste Management Area B-BX-BY. RPP-10098, CH2M HILL Hanford Group, Inc., Richland, WA.

Kohler M, BD Honeyman, and JO Leckie. 1999. "Neptunium(V) sorption on hematite $\left(\alpha-\mathrm{Fe}_{2} \mathrm{O}_{3}\right)$ in aqueous suspension: The effect of $\mathrm{CO}_{2}$." Radiochim. Acta 85:33-48.

Korte NE, J Skopp, WH Fuller, EE Niebla, and BA Alesii. 1976. "Trace element movement in soils: Influence of soil physical and chemical properties.” Soil Sci. J. 122:350-359.

Krupka KM and RJ Serne. 1998. Effects on Radionuclide Concentrations by Cement/Groundwater Interactions in Support of Performance Assessment of Low-Level Radioactive Waste Disposal Facilities. NUREG/CR-6377 (PNNL-11408), Pacific Northwest National Laboratory, Richland, WA.

Langmuir D. 1978. "Uranium solution-mineral equilibria at low temperatures with applications to sedimentary ore deposits." Geochim. Cosmo. Acta 42:547-569.

Langmuir D. 1979. "Techniques of estimating thermodynamic properties for some aqueous complexes of geochemical interest." Chemical Modeling in Aqueous Systems, EA Jenne (ed.), pp. 353-387. American Chemical Society, Washington, DC.

Langmuir D. 1997. Aqueous Environmental Geochemistry. Prentice Hall, Upper Saddle River, NJ.

Leckie JO, MM Benjamin, K Hayes, G Kaufman, and S Altman. 1980. Adsorption/Coprecipitation of Trace Elements from Water with Iron Oxyhydroxides. EPRI-RP-910, Electric Power Research Institute, Palo Alto, CA.

Lemire RJ, GD Boyer, and AB Campbell. 1993. "The solubilities of sodium and potassium dioxoneptunium(V) carbonate hydrates at $30^{\circ}, 50^{\circ}$, and $75^{\circ} \mathrm{C} . "$ Radiochim. Acta 61:57-63.

Lemire RJ, J Fuger, H Nitsche, P Potter, MH Rand, J Rydbrg, K Spahiu, JC Sullivan, WJ Ullman, P Vitorge, and H Wanner. 2001. Chemical Thermodynamics, Volume 4: Chemical Thermodynamics of Neptunium and Plutonium. Elsevier Science Publishing Company, Inc., New York.

Lemire RJ. 1984. An Assessment of the Thermodynamic Behavior of Neptunium in Water and Model Groundwater from $25^{\circ}$ to $150^{\circ} \mathrm{C}$. AECL-7817, Atomic Energy of Canada Limited (AECL), Pinawa, Manitoba, Canada.

Lieser KH. 1993. "Technetium in the nuclear fuel cycle, in medicine and in the environment." Radiochim. Acta 63:5-8. 
Lieser KH and U Mühlenweg. 1988. "Neptunium in the hydrosphere and in the geosphere. I. Chemistry of neptunium in the hydrosphere and sorption of neptunium from groundwaters on sediments under aerobic and anaerobic conditions." Radiochim. Acta 44/45:129-133.

Lieser KH and Th Steinkopff. 1989. "Chemistry of radioactive iodine in the hydrosphere and in the geosphere.” Radiochim. Acta 46:49-55.

Lindenmeier CW, RJ Serne, JL Conca, AT Owen, and MI Wood. 1995. Solid Waste Leach Characteristics and Contaminant-Sediment Interactions Volume 2: Contaminant Transport under Unsaturated Moisture Contents. PNL-10722, Pacific Northwest National Laboratory, Richland, WA.

Lindsay WL. 1979. Chemical Equilibria in Soils. John Wiley and Sons, New York.

Lindsay WL, M Sadiq, and KL Porter. 1981. "Thermodynamics of inorganic nitrogen transformation." Soil Sci. Soc. Am. J. 45:61-66.

Liu CX, JM Zachara, and SC Smith. 2004. "A cation exchange model to describe $\mathrm{Cs}^{+}$sorption at high ionic strength in subsurface sediments at Hanford Site, USA.” J. Contam. Hydrol. 68:217-238.

Liu CX, JM Zachara, O Qafoku, and SC Smith. 2003a. "Effect of temperature on $\mathrm{Cs}^{+}$sorption and desorption in subsurface sediments at the Hanford Site, USA." Environ. Sci. Tech. 37:2640-2645.

Liu CX, JM Zachara, O Qafoku, SC Smith, JP McKinley, and CC Ainsworth. 2003b. "Desorption kinetics of radiocesium from subsurface sediments at the Hanford Site, USA." Geochim. Cosmo. Acta 67:2893-2912.

Livens FR, MJ Jones, AJ Hynes, JM Charnock, JFW Mosselmans, C Hennig, H Steele, D Collison, DJ Vaughan, RAD Pattrick, WA Reed, and LN Moyes. 2004. "X-ray absorption studies of reactions of technetium, uranium and neptunium with mackinawite." J. Environ. Radioactivity 74:211-219.

Lovley DR. 1993. "Dissimilatory metal reduction.” Annual Rev. Microbiol. 47:263-290.

Lovley DR. 1995. "Bioremediation of organic and metal contaminants with dissimilatory metal reduction." J. Indust. Microbio. 14:85-93.

Lloyd JR and LE Macaskie. 1996. "A novel phoshor imager-based technique for monitoring the microbial reduction of technetium." Appl. Environ. Microbio. 62(2):578-582.

Lloyd JR, JA Cole, and LE Macaskie. 1997. "Reduction and removal of heptavalent technetium from solution by Escherichia coli.” J. Bacteriology 179(6):2014-2021.

Lloyd JR, HF Nolting, VA Solé, K Bosecker, and LE Macaskie. 1998. "Technetium reduction and precipitation by sulfate-reducing bacteria." Geomicrobio. J. 15:45-58.

Lloyd JR, J Ridley, T Khizniak, NN Lyalikova, and LE Macaskie. 1999. "Reduction of technetium by Desulfovibrio desulfuricans: Biocatalyst characterization and use in a flowthrough bioreactor." Appl. Environ. Microbio. 65:2691-2696. 
Lloyd JR, P Yong, and LE Macaskie. 2000a. "Biological reduction and removal of Np(V) by two microorganisms.” Environ. Sci. Tech. 34:1297-1301.

Lloyd JR, VA Sole, CVG Van Praagh, and DR Lovley. 2000b. "Direct and Fe(II)-mediated reduction of technetium by Fe(III)-reducing bacteria.” Appl. Environ. Microbio. 66:3743-3749.

Losi ME and WT Frankenberger, Jr (eds). 1998. "Reduction of selenium oxyanions by Enterobacter cloacae strain SLD1a-1.” Environmental Chemistry of Selenium, pp. 515-544. Marcel Dekker, Inc., New York.

Macalady DL, PG Tratnyek, and TJ Grundl. 1986. "Abiotic reduction reactions of anthropogenic organic chemicals in anaerobic systems: A critical review." J. Contam. Hydrol. 1:1-28.

MacNaughton MG. 1977. "Adsorption of chromium(VI) at the oxide-water interface." Biological Implications of Metals in the Environment, H Drucker and RF Wildung (eds.), pp. 244-253. CONF-750929, National Technical Information Service, Springfield, VA.

Maher K, DJ DePaolo, ME Conrad, and RJ Serne. 2003. "Vadose zone infiltration rate at Hanford, Washington, inferred from Sr isotope measurements." Water Resources Res. 39:SBH 3-1-SBH 3-14.

Mann FM. 2003. Annual Summary of the Immobilized Low-Activity Waste Performance Assessment for 2003. Incorporating the Integrated Disposal Facility Concept. DOE/OPR-2000-19, Rev. 3, Office of River Protection, U.S. Department of Energy, Richland, WA.

Mann FM, RJ Puigh, SH Finfrock, R Khaleel, and MI Wood. 2003a. Integrated Disposal Facility Risk Assessment. RPP-15834, Rev. 0, CH2M HILL Hanford Group, Inc., Richland, WA.

Mann, FM, BP McGrail, DH Bacon, RJ Serne, KM Krupka, RJ Puigh, R Khaleel, and S Finfrock. 2003b. Risk Assessment Supporting the Decision on the Initial Selection of Supplemental ILAW Technologies. RPP-17675, CH2M HILL Hanford Group, Inc., Richland, WA.

Mann FM, KC Burgard, WR Root, RJ Puigh, SH Finfrock, R Khaleel, DH Bacon, EJ Freeman, BP McGrail, SK Wurstner, and PE LaMont. 2001. Hanford Immobilized Low-Activity Waste Performance Assessment: 2001 Version. DOE/ORP-2000-24, Rev. 0, U.S. Department of Energy, Office of River Protection, Richland, WA.

Mann, FM, RJ Puigh, II, PD Rittmann, NW Kline, JA Voogd, Y Chen, CR Eiholzer, CT Kincaid, BP McGrail, AH Lu, GF Williamson, NR Brown, and PE LaMont. 1998. Hanford Immobilized LowActivity Tank Waste Performance Assessment. DOE/RL-97-69, Rev. 0, U.S. Department of Energy, Richland Operations Office, Richland, WA.

Martin WJ. 1996. Integration of Risk Analysis and Sorption Studies in the Subsurface Transport of Aqueous Carbon-14 at the Hanford Site. Ph.D. Dissertation, Washington State University, Pullman, WA. 
Mattigod SV, RJ Serne, BP McGrail, and VL LeGore. 2002. "Radionuclide incorporation in secondary crystalline minerals from chemical weathering of waste glasses." Scientific Basis for Nuclear Waste Management XX, BP McGrail and G Cragliano (eds.), pp. 597-604, Vol. 713. Materials Research Society, Pittsburgh, PA.

Mattigod SV, DI Kaplan, VL LeGore, RD Orr, HT Schaef, and JS Young. 1998. Radionuclide Incorporation in Secondary Crystalline Minerals Resulting from Chemical Weathering of Selected Waste Glasses. PNNL-12005, Pacific Northwest National Laboratory, Richland, WA.

Mattigod SV, RJ Serne, VL LeGore, KE Parker, RD Orr, DE McCready, and JS Young. 2003. Radionuclide Incorporation in Secondary Crystalline Minerals Resulting from Chemical Weathering of Selected Waste Glasses: Progress Report: Task kd.5b. PNNL-14391, Pacific Northwest National Laboratory, Richland, WA.

Mayland HF, LF James, KE Panter, and JL Sonderegger. 1989. "Selenium in seleniferous environments." Selenium in Agriculture and the Environment, LW Jacobs (ed.), pp. 15-50. SSSA Special Publication Number 23, Soil Science Society of America, Madison, WI.

Mazzi U. 1989. "The coordination chemistry of technetium in its intermediate oxidation states." Polyhedron 8:1683-1688.

McGrail BP and DH Bacon. 1998. Selection of a Computer Code for Hanford Low-Level Waste Engineered-System Performance Assessment. PNNL-10830 Rev. 1, Pacific Northwest National Laboratory, Richland, WA.

McGrail BP, DH Bacon, JP Icenhower, WL Ebert, PF Martin, HT Schaef, and EA Rodriguez. 1999. Waste Form Release Data Package for the 2001 Immobilized Low-Activity Waste Performance Assessment. PNNL-13043, Pacific Northwest National Laboratory, Richland, WA.

McGraw MA and DI Kaplan. 1997. Colloid Suspension Stability and Transport through Unsaturated Porous Media. PNNL-11565, Pacific Northwest National Laboratory, Richland, WA.

McKinley JP, SM Heald, JM Zachara, and CT Resch. 2002. "The identification of uranium-bearing phases by X-ray microprobe, electron microprobe, and scanning electron microscopy." Appendix D, Section D.3.2 in "Digest of Science and Technology Program Evaluations" in Field Investigation Report for Waste Management Area B-BX-BY. Volume 2, Appendices, AJ Knepp, (ed.), pp. D-122 to D-139. RPP-10098, CH2M HILL Hanford Group, Inc., Richland, WA.

McKinley JP, JM Zachara, SM Heald, A Dohnalkova, MG Newville, and SR Sutoon. 2004. "Microscale distribution of cesium sorbed to biotite and muscovite." Environ. Sci. Tech. 38:1017-1023.

McKinley JP, CJ Zeissler, JM Zachara, RJ Serne, RM Lindstrom, HT Schaef, and RD Orr. 2001. "Distribution and retention of ${ }^{137} \mathrm{Cs}$ in sediments at the Hanford Site, Washington." Environ. Sci. Tech. 35:3433-3441. 
McNeal JM and LS Balistrieri. 1989. "Geochemistry and occurrence of selenium: An overview." Selenium in Agriculture and the Environment, LW Jacobs (ed.), pp. 1-13. SSSA Special Publication Number 23, Soil Science Society of America, Madison, WI.

Meyer PD, KP Saripalli, and VL Freedman. 2004. Near-Field Hydrology Data Package for the Integrated Disposal Facility 2005 Performance Assessment. PNNL-14700, Pacific Northwest National Laboratory, Richland, WA.

Meyer RE, WD Arnold, and FI Case. 1984. Valence Effects on the Adsorption of Nuclides on Rocks and Minerals. NUREG/CR-3389 (ORNL-5978), prepared for the U.S. Nuclear Regulatory Commission by Oak Ridge National Laboratory, Oak Ridge, TN.

Meyer RE, WD Arnold, and FI Case. 1985. Valence Effects on the Adsorption of Nuclides on Rocks and Minerals II. NUREG/CR-4114, prepared for the U.S. Nuclear Regulatory Commission by Oak Ridge National Laboratory, Oak Ridge, TN.

Meyer RE, WD Arnold, FI Case, and GD O'Kelley. 1991. "Solubilities of Tc(IV) oxides." Radiochim. Acta 55:11-18.

Morel FMM. 1983. Principles of Aquatic Chemistry. John Wiley and Sons, New York.

Morris DE, PG Allen, JM Berg, CJ Chisholm-Brause, SD Conradson, RJ Donohoe, NJ Hess, JA Musgrave, and C Drew Tait. 1996. "Speciation of uranium in Fernald soils by molecular spectroscopic methods: Characterization of untreated soils." Envir. Sci. Tech. 30:2322-2331.

Moser DP, JK Fredrickson, DR Geist, EV Arntzen, AD Peacock, SMW Li, T Spadoni, and JP McKinley. 2003. "Biogeochemical processes and microbial characteristics across groundwater-surface water boundaries of the Hanford reach of the Columbia River." Environ. Sci. Tech. 37:5127-5134.

Mozeto AA, P Fritz, and EJ Reardon. 1983. "Experimental observation of carbon isotope exchange in carbonate-water system." Geochim. Cosmo. Acta 48:495-504.

Mucciard AN, TC Johnson, and J Saunier. 1980. "Statistical investigation of the mechanics controlling radionuclide sorption, part III." Task 4, Third Contractor Information Meeting, JF Relyea (ed.), Vol. 1, pp. 1-75. PNL-SA-8571, Pacific Northwest Laboratory, Richland, WA.

Mucciard AN, IJ Booker, EC Orr, and D Cleveland. 1979. "Statistical investigation of the mechanics controlling radionuclide sorption, Part II." Task 4, Second Contractor Information Meeting, RJ Serne (ed.), Vol. 2, pp. 333-425. PNL-SA-7352, Pacific Northwest Laboratory, Richland, WA.

Muramatsu Y, S Uchida, P Sriyotha, and K Sriyotha. 1990. "Some considerations of the sorption and desorption phenomena of iodide and iodate on soil." Water, Air, and Soil Pollution 49:125-138.

Nakashima S, JR Disnar, A Perruchot, and J Trichet. 1984. "Experimental study of mechanisms of fixation and reduction of uranium by sedimentary organic matter under diagenetic or hydrothermal conditions." Geochim. Cosmo. Acta 48:2321-2329. 
Nakayama E, T Kumamoto, S Tsurubo, and T Fujinaga. 1981. "Chemical speciation of chromium in sea water. Part 2. Effects of manganese oxides and reducible organic materials on the redox processes of chromium." Analytica Chim. Acta 130:401-404.

Nakayama S, T Yamaguchi, and K Sekine. 1996. "Solubility of neptunium(IV) hydrous oxide in aqueous solutions." Radiochim. Acta 74:15-19.

Nash K, S Fried, AM Freidman, and JC Sullivan. 1981. "Redox behavior, complexing, and adsorption of hexavalent actinides by humic acid and selected clays." Environ. Sci. Tech. 15:834-837.

National Academy of Sciences (NAS). 1976. Selenium. Medical and Biologic Effects of Environmental Pollutants. Washington, DC.

Neck V, W Runde, JI Kim, and B Kandellakopulos. 1994. "Solid-liquid equilibrium reactions of neptunium(V) in carbonate solution at different ionic strengths." Radiochim. Acta 65:29-37.

Nelson DC, WH Casey, JD Sison, EE Mack, A Ahmad, and JS Pollack. 1996. "Selenium uptake by sulfur-accumulating bacteria." Geochim. Cosmo. Acta 60:3531-3539.

Nelson JL. 1959. Soil Column Studies with Radiostrontium. Effects of Temperature and of Species of Accompany Ion. HW-62035, General Electric Company, Richland, WA.

Nordstrom DK and JL Munoz. 1985. Geochemical Thermodynamics. The Benjamin/Cummings Publishing Co., Inc., Menlo Park, CA.

Novak CF and KE Roberts. 1995. "Thermodynamic modeling of neptunium(V) solubility in concentrated Na- $\mathrm{CO}_{3}-\mathrm{HCO}_{3}-\mathrm{Cl}-\mathrm{ClO}_{4}-\mathrm{H}-\mathrm{OH}-\mathrm{H}_{2} \mathrm{O}$ systems." Scientific Basis for Nuclear Waste Management XVIII, T Murakami and RC Ewing (eds.), pp. 1119-1128, Vol. 53. Materials Research Society, Pittsburgh, PA.

Nriagu JO and E Nieboer (eds.). 1988. Chromium in the Natural and Human Environments, Volume 20. John Wiley and Sons, New York.

Nyman M, JL Krumhansl, P Zhang, H Anderson, and TM Nenoff. 2000. "Chemical evolution of leaked high-level liquid wastes in Hanford soils." Scientific Basis for Nuclear Waste Management XXIII, RW Smith and DW Shoesmith (eds.), pp. 225-230, Material Research Society Symposium Proceedings, Vol. 608, Material Research Society, Pittsburgh, PA.

Onishi Y, RJ Serne, EM Arnold, and C E Cowan, and FL Thompson. 1981. Critical Review: Radionuclide Transport, Sediment Transport, and Water Quality Mathematical Modeling; and Radionuclide Adsorption/Desorption Mechanisms. NUREG/CR-1322 (PNL-2901), prepared for the U.S. Nuclear Regulatory Commission, Washington, DC by Pacific Northwest National Laboratory, Richland, WA.

Palmer CD. 2000. "Precipitates in a Cr(VI)-contaminated concrete." Environ. Sci. Tech. 34:4185-4192.

Palmer CD and PR Wittbrodt. 1991. "Processes affecting the remediation of chromium-contaminated sites." Environ. Health Perspectives 92:25-40. 
Palmer CD and RW Puls. 1994. Natural Attenuation of Hexavalent Chromium in Groundwater and Soils. EPA/540/S-94/505, U.S. Environmental Protection Agency, Ada, OK.

Paquette J and WE Lawrence. 1985. "A spectroelectrochemical study of the technetium(IV)/ technetium(III) couple in bicarbonate solutions.” Canadian J. Chem. 63:2369-2373.

Parson R. 1982. “Surface properties of oxides.” J. Electroanal. Chem. 118:2-18.

Payne TE and TD Waite. 1991. "Surface complexation modeling of uranium sorption data obtained by isotope exchange techniques." Radiochim. Acta 52-3:487-493.

Pierce EM, BP McGrail, EA Rodriguez, HT Schaef, KP Saripalli, RJ Serne, KM Krupka, PF Martin, SR Baum, KN Geiszler, LR Reed, and WJ Shaw. 2004. Waste Form Release Data Package for the 2005 Integrated Disposal Facility Performance Assessment. PNNL-14805, Pacific Northwest National Laboratory, Richland, WA.

Pilkington NJ and NS Stone. 1990. The Solubility and Sorption of Nickel and Niobium under High pH Conditions. NSS/R-186, Harwell Laboratory, Oxfordshire, UK.

Pilkington NJ. 1990. "The solubility of technetium in the near-field environment of a radioactive waste repository.” J. Less-Common Metals 161:203-211.

Plackett RL and JP Burman. 1946. "The design of optimum multifactorial experiments." Biometrika 33:305-325.

Poole SC and E Porter. 1999. "Selenium (IV) reduction by Bacillus and Desulfovibrio in the presence of iron(II, III)." Wetlands and Remediation, JL Means and RE Hinchee (eds.), pp. 431-438. Battelle Press, Columbus, $\mathrm{OH}$.

Pourbaix M. 1966. Atlas of Electrochemical Equilibria. Pergamon Press, Oxford, UK.

Prout WE. 1959. Adsorption of Fission Products by Savannah River Plant Soil. DP-394, Savannah River National Laboratory, Aiken, SC.

Puigh RJ. 2004. Facility Data for the Hanford Integrated Disposal Facility Performance Assessment. RPP-20691 Rev. 0, Fluor Federal Services, Inc., Richland, WA.

Puigh RJ, MI Wood, and DW Wootan. 2004. Inventory Data Package for the 2005 Integrated Disposal Facility Performance Assessment. RPP-20692, Rev. 0, Fluor Federal Services, Inc., Richland, WA.

Qafoku NP, CC Ainsworth, JE Szecsody, and OS Qafoku. 2003a. "Aluminum effect on dissolution and precipitation under hyperalkaline conditions: I. Liquid phase transformations. J. Environ. Qual. 32:2354-2363.

Qafoku NP, CC Ainsworth, JE Szecsody, OS Qafoku, and SM Heald. 2003b. "Effect of coupled dissolution and redox reactions on $\mathrm{Cr}(\mathrm{VI})_{\mathrm{aq}}$ attenuation during transport in the sediments under hyperalkaline conditions." Environ. Sci. Tech. 37:3640-3646. 
Qafoku NP, CC Ainsworth, JE Szecsody, DL Bish, JS Young, DE McCready, and OS Qafoku. 2003c. "Aluminum effect on dissolution and precipitation under hyperalkaline conditions: II. Solid phase transformations. J. Environ. Qual. 32:2364-2372.

Qafoku NP, CC Ainsworth, JE Szecsody, and OS Qafoku. 2004. "Transport-controlled kinetics of dissolution and precipitation in the sediments under alkaline and saline conditions." Geochim. Cosmo. Acta. 68:2981-2995.

Ohlendorf HM, AW Kilness, JL Simmons, RK Stroud, DJ Hoffman, and JF Moore. 1988. "Selenium toxicosis in wild aquatic birds." J. Toxicol. Environ. Health 24:67 92.

Rai D, JM Zachara, AP Schwab, RL Schmidt, DC Girvin, and JE Rogers. 1984. Chemical Attenuation Rates, Coefficients, and Constants in Leachate Migration. Volume 1: A Critical Review. EA-3356, Electric Power Research Institute, Palo Alto, CA.

Rai D and JL Ryan. 1985. "Neptunium(IV) hydrous oxide solubility under reducing and carbonate conditions." Inorg. Chem. 24:247-251.

Rai D, BM Sass, and DA Moore. 1987a. "Chromium(III) hydrolysis constants and solubility of chromium(III) hydroxide.” Inorg. Chem. 26:345-349.

Rai D, JL Swanson, and JL Ryan. 1987b. "Solubility of $\mathrm{NpO}_{2} \cdot \mathrm{xH}_{2} \mathrm{O}(\mathrm{am})$ in the presence of $\mathrm{Cu}(\mathrm{I}) / \mathrm{Cu}(\mathrm{II})$ redox buffer." Radiochim. Acta 42:35-41.

Rai, D, CC Ainsworth, LE Eary, SV Mattigod. 1987c. Inorganic and Organic Constituents in Fossil Fuel Combustion Residues. Volume 1: A Critical Review. EPRI EA-5176, prepared for the Electric Power Research Institute, Palo Alto, CA by Pacific Northwest National Laboratory, Richland, WA.

Rai D, JM Zachara, LE Eary, CC Ainsworth, JD Amonette, CE Cowan, RW Szelmeczka, CT Resch, RL Schmidt, SC Smith, and DC Girvin. 1988. Chromium Reactions in Geologic Materials. EPRI-EA-5741, Electric Power Research Institute, Palo Alto, CA.

Rai D, NJ Hess, AR Felmy, DA Moore, and M Yui. 1999. "A thermodynamic model for the solubility of $\mathrm{NpO}_{2}(\mathrm{am})$ in the aqueous $\mathrm{K}^{+}-\mathrm{HCO}_{3}{ }^{-}-\mathrm{CO}_{3}{ }^{2-}-\mathrm{OH}^{-}-\mathrm{H}_{2} \mathrm{O}$ system." Radiochim. Acta 84:159-169.

Rajan SS. 1979. "Adsorption of selenite, phosphate, and sulfate on hydrous alumina." J. Soil Sci. 30:709-718.

Ramsay JDF. 1988. "The role of colloids in the release of radionuclides from nuclear waste." Radiochim. Acta 44/45:165-170.

Rancon D. 1973. "The behavior in underground environments of uranium and thorium discharged by the nuclear industry." Environmental Behavior of Radionuclides Released in the Nuclear Industry, pp. 333346. IAEA-SM-172/55, International Atomic Energy Association, Vienna.

Rard JA, MH Rand, G Anderegg, and H Wanner. 1999. Chemical Thermodynamics, Volume 3: Chemical Thermodynamics of Technetium. Elsevier Science Publishing Company, Inc., New York. 
Read D, TA Lawless, RJ Sims, and KR Butter. 1993. "Uranium migration through intact sandstone cores." J. Contam. Hydrol. 13:277-289.

Reidel SP. 2004. Geologic Data Package for 2005 Integrated Disposal Facility Waste Performance Assessment. PNNL-14586, Pacific Northwest National Laboratory, Richland, WA.

Reidel SP, KD Reynolds, and DG Horton. 1998. Immobilized Low-Activity Waste Site Borehole 299-E17-21. PNNL-11957, Pacific Northwest National Laboratory, Richland, WA.

Rhoades K, BN Bjornstad, RE Lewis, SS Teel, KJ Cantrell, RJ Serne, LH Sawyer, JL Smoot, JE Smoot, JE Szecsody, MS Wigmosta, and SK Wurstner. 1994. Estimation of the Release and Migration of Nickel Through Soils and Groundwater at the Hanford Site 218-E-12B Burial Ground. PNL-9791, Pacific Northwest Laboratory, Richland, WA.

Rhodes DW and JL Nelson. 1957. Disposal of Radioactive Liquid Wastes from the Uranium Recovery Plant. HW-54721, HW-67201, General Electric Company, Richland, WA.

Rhodes DW. 1957a. "The effect of $\mathrm{pH}$ on the uptake of radioactive isotopes from solution by a soil." Soil Sci. Soc. Am. Proc. 21:389-392.

Rhodes DW. 1957b. "The adsorption of Pu by soil.” Soil Sci. 84:465-471.

Richard FC and ACM Bourg. 1991. "Aqueous geochemistry of chromium: A Review." Water Research 25:807-816.

Rimstidt JD and HL Barnes. 1980. "The kinetics of silica-water reactions." Geochim. Cosmo. Acta 44:1683-1699.

Roberts KE, HB Silber, PC Torretto, T Prussin, K Becraft, DE Hobart, and CF Novak. 1996. "The experimental determination of the solubility product for $\mathrm{NpO}_{2} \mathrm{OH}$ in $\mathrm{NaCl}$ solutions." Radiochim. Acta 74:27-30.

Robertson DE. 1974. Physicochemical Characterization of N-Reactor Effluent Radionuclides in Soil and Water Systems. BNWL-1950, Battelle, Pacific Northwest Laboratories, Richland, WA.

Robertson DE, DA Cataldo, BA Napier, KM Krupka and LB Sasser. 2003. Literature Review and Assessment of Plant and Animal Transfer Factors Used in Performance Assessment Modeling.

NUREG/CR-6825 (PNNL-14321), prepared for the U.S. Nuclear Regulatory Commission by the Pacific Northwest National Laboratory, Richland, WA.

Roh Y, SR Lee, SK Choi, MP Elless, and SY Lee. 2000. "Physicochemical and mineralogical characterization of uranium-contaminated soils." Soil Sediment Contam. 9:463-486.

Routson RC and RJ Serne. 1972. One-Dimensional Model of the Movement of Trace Radioactive Solute through Soil Columns: The PERCOL Model. BNWL-1718, Battelle Northwest, Richland, WA.

Routson RC, G Jansen, and AV Robinson. 1976. "241-Am, 237-Np, and 99-Tc sorption on two United States subsoils from differing weathering intensity areas." Health Phys. 33:311-317. 
Routson RC, GS Barney, and RO Seil. 1978. Measurement of Fission Product Sorption Parameters for Hanford 200 Area Sediment Types. Progress Report. RHO-LD-73, Rockwell Hanford Operations, Richland, WA.

Routson RC, GS Barney, RH Smith, CH Delegard, and L Jensen. 1981. Fission Product Sorption Parameters for Hanford 200-Area Sediment Types. RHO-ST-35, Rockwell Hanford Operations, Richland, WA.

Sandino A and J Bruno. 1992. "The solubility of $\left(\mathrm{UO}_{2}\right)_{3}(\mathrm{PO} 4)_{2} \cdot \mathrm{H}_{2} \mathrm{O}(\mathrm{s})$ and the formation of U(VI) phosphate complexes: their influence in uranium speciation in natural waters." Geochim. Cosmo. Acta $56: 4135-4145$.

Sarott FA, MH Bradbury, P Pandjolfo, and P Spieler. 1992. "Diffusion and absorption studies on hardened cement paste and the effect of carbonation on diffusion rates." Cement and Concrete Research 22:439-444.

Sass BM and D Rai. 1987. "Solubility of amorphous chromium(III)-iron(III) hydroxide solid solutions." Inorg. Chem. 26:2228-2232.

Schindler PW and G Sposito. 1991. "Surface complexation at (hydro)oxide surfaces." Interactions at the Soil Colloid-Soil Solution Interface, GH Bolt, MF DeBoodt, MHB Hayes, and MB McBride (eds.), pp. 115-145. Kluwer Academic Publishers, Amsterdam.

Schulte EH and P Scoppa. 1987. "Sources and behavior of technetium in the environment." Sci. Total Environ. 64:163-168.

Serne RJ. 1990. "Grouted waste leach tests: pursuit of mechanisms and data for long-term performance assessment." Scientific Basis for Nuclear Waste Management XIII, VM Oversby and PW Brown (eds.), pp. 91-99, Vol. 176. Materials Research Society, Pittsburgh, PA.

Serne RJ and JF Relyea. 1983. "The status of radionuclide sorption-desorption studies performed by the WRIT Program." The Technology of High-Level Nuclear Waste Disposal, Vol. 1, pp. 203-254.

DOE/TIC-621, Technical Information Center, U.S. Department of Energy, Oak Ridge, TN.

Serne RJ, DS Burke, and KM Krupka. 1999. Uranium Solubility Tests in Support of Solid Waste Burial. PNNL-12242, Pacific Northwest National Laboratory, Richland, WA.

Serne RJ, RO Lokken, and LJ Criscenti. 1992. "Characterization of grouted low-level waste to support performance assessment.” Waste Management 12:271-288.

Serne RJ, RC Routson, and DA Cochran. 1973. Experimental Methods for Obtaining PERCOL Model Input Verification Data. BNWL-1721, Pacific Northwest Laboratory, Richland, WA.

Serne RJ, JL Conca, VL LeGore, KJ Cantrell, CW Lindenmeier, JA Campbell, JE Amonette, and MI Wood. 1993. Solid-Waste Leach Characteristics and Contaminant-Sediment Interactions. Volume 1: Batch Leach and Adsorption Tests and Sediment Characterization. PNL-8889, Vol. 1, Pacific Northwest Laboratory, Richland, WA. 
Serne RJ, JM Zachara, and DS Burke. 1998. Chemical Information on Tank Supernatants, Cs Adsorption from Tank Liquids onto Hanford Sediments, and Field Observations of Cs Migration from Past Tank Leaks. PNNL-11495, Pacific Northwest National Laboratory, Richland, WA.

Serne RJ, CF Brown, HT Schaef, EM Pierce, MJ Lindberg, Z Wang, P Gassman, and J Catalano. 2002a. 300 Area Uranium Leach and Adsorption Project. PNNL-14022, Pacific Northwest National Laboratory, Richland, WA.

Serne RJ, BN Bjornstad, GW Gee, HT Schaef, RG McCain, DC Lanigan, CW Lindenmeier, RD Orr, VL LeGore, RE Clayton, MJ Lindberg, IV Kutnyakov, SR Baum, KN Geiszler, M M Valenta, TS Vickerman, and LJ Royack. 2002b. Characterization of Vadose Zone Sediment: Borehole 299-E3346 Near B-110 in the B-BX-BY Waste Management Area. PNNL-14119, Pacific Northwest National Laboratory, Richland, WA.

Serne RJ, GV Last, GW Gee, HT Schaef, DC Lanigan, CW Lindenmeier, RE Clayton, VL LeGore, RD Orr, MJ O'Hara, CF Brown, DS Burke, AT Owen, IV Kutnyakov, and TC Wilson. 2002c. Geologic and Geochemical Data Collected from Vadose Zone Sediments from Borehole SX 41-09-39 in the S/SX Waste Management Area and Preliminary Interpretations. PNNL-13757-3, Pacific Northwest National Laboratory, Richland, WA.

Serne RJ, GV Last, GW Gee, HT Schaef, DC Lanigan, CW Lindenmeier, MJ Lindberg, RE Clayton, VL LeGore, RD Orr, IV Kutnyakov, SR Baum, KN Geiszler, CF Brown, MM Valenta, and TS Vickerman. 2002d. Characterization of Vadose Zone Sediment: Borehole 299-E33-45 Near BX-102 in the B-BX-BY Waste Management Area. PNNL-14083, Pacific Northwest National Laboratory, Richland, WA.

Serne RJ, GV Last, HT Schaef, DC Lanigan, CW Lindenmeier, CC Ainsworth, RE Clayton, VL LeGore, MJ O’Hara, CF Brown, RD Orr, IV Kutnyakov, TC Wilson, KB Wagnon, BA Williams, and DB Burke. 2002e. Geologic and Geochemical Data and Preliminary Interpretations of Vadose Zone Sediment from Slant Borehole SX-108 in the S-SX Waste Management Area. PNNL-13757-4, Pacific Northwest National Laboratory, Richland, WA.

Serne RJ, BN Bjornstad, DG Horton, DC Lanigan, CW Lindenmeier, MJ Lindberg, RE Clayton, VL LeGore, RD Orr, IV Kutnyakov, SR Baum, KN Geiszler, MM Valenta, and TS Vickerman. 2004a. Characterization of Vadose Zone Sediments Below the T Tank Farm: Boreholes C4104, C4105, 299W10-196 and RCRA Borehole 299-W11-39. PNNL-14849, Pacific Northwest National Laboratory, Richland, WA.

Serne RJ, BN Bjornstad, DG Horton, DC Lanigan, CW Lindenmeier, MJ Lindberg, RE Clayton, VL LeGore, RD Orr, IV Kutnyakov, SR Baum, KN Geiszler, MM Valenta, and TS Vickerman. 2004b. Characterization of Vadose Zone Sediments Below the TX Tank Farm: Boreholes C3830, C3831, C3832 and RCRA Borehole 299-W10-27. PNNL-14594, Pacific Northwest National Laboratory, Richland, WA.

Shanbhag PM and GR Choppin. 1981. "Binding of uranyl by humic acid." J. Inorg. Nucl. Chem. 43:3369-3375. 
Sheppard JC, JA Kittrick, and TL Hart. 1976. Determination of Distribution Ratios and Diffusion Coefficients of Neptunium, Americium, and Curium in Soil-Aquatic Environments. RLO-221-T-12-2, Rockwell Hanford Operations, Richland, WA.

Sheppard SC, MI Sheppard, and WG Evenden. 1990. "A novel method used to examine variation in Tc sorption among 34 soils, aerated and anoxic.” J. Environ. Radioact. 11:215-2121.

Silva RJ and H Nitsche. 1995. “Actinide environmental chemistry.” Radiochim. Acta 70/71:377-396.

Silva RJ, G Bidoglio, MH Rand, PB Robouch, H Wanner, and I Puigdomenech. 1995. Chemical Thermodynamics, Volume 2: Chemical Thermodynamics of Americium. North-Holland, Elsevier Science Publishing Company, Inc., New York.

Singh M, N Singh, and PS Realan. 1981. "Adsorption and desorption of selenite and selenate selenium on different soils." Soil Science 132:134-141.

Snedecor GW and WC Cochran. 1967. Statistical Methods. $6^{\text {th }}$ edition, Iowa State University Press, Ames, IA.

Sparks ST and SE Long. 1987. The Chemical Speciation of Technetium in the Environment: A Literature Study. DOE/RW 88.098 (UKAEA/DOE Radiological Protection Research Programme Letter AERE-R 12743), Harwell Laboratory, Oxfordshire, UK.

Sposito G. 1984. The Surface Chemistry of Soils. Oxford University Press, New York.

Sposito G. 1989. The Chemistry of Soils. Oxford University Press, New York.

Sposito G. 1994. Chemical Equilibria and Kinetics in Soils. Oxford University Press, New York.

Stalmans M, A Maes, and A Cremers. 1986. "Role of organic matter as a geochemical sink for technetium in soils and sediments." Technetium in the Environment, G Desmet and C Myttenaere (eds.), pp. 91-113. Elsevier Applied Science Publishers, Amsterdam.

Steefel CI, S Carroll, PH Zhao, and S Roberts. 2003. "Cesium migration in Hanford sediment: A multisite cation exchange model based on laboratory transport experiments." J. Contam. Hydrol. 67:219-246.

Strieg1 RG and DE Armstrong. 1990. "Carbon dioxide retention and carbon exchange on unsaturated quaternary sediments.” Geochim. Cosmo. Acta 54:2277-2283.

Stumm W and JJ Morgan. 1981. Aquatic Chemistry. An Introduction Emphasizing Chemical Equilibria in Natural Waters. John Wiley and Sons, New York.

Susak NJ, A Friedman, S Fried, and JC Sullivan. 1983. "The reduction of neptunium(VI) by basalt and olivine." Nucl. Tech. 63:266-270. 
Suzuki Y and JF Banfield. 1999. "Geomicrobiology of uranium.” Reviews in Mineralogy. Vol. 38. Uranium: Mineralogy, Geochemistry and the Environment, PC Burns and R Finch (eds.), pp. 393-432. Mineralogical Society of America, Washington, DC.

Tallent OK, EW McDaniel, GD Del Cul, KE Dodson, and DR Trotter. 1988. "Immobilization of technetium and nitrate in cement-based materials." Scientific Basis for Nuclear Waste Management XI, MJ Apted and RE Westerman (eds.), pp. 23-32, Vol. 112. Materials Research Society, Pittsburgh, PA.

Tanaka S, M Yamawaki, S Nagasaki, and H Moriyama. 1992. "Geochemical behavior of neptunium." J. Nucl. Sci. Tech. 29:706-718.

Thibault DH, MI Sheppard, and PA Smith. 1990. A Critical Compilation and Review of Default Soil Solid/Liquid Partition Coefficients, $K_{d}$, for Use in Environmental Assessments. AECL-10125, Whiteshell Nuclear Research Establishment, Atomic Energy of Canada Limited, Pinawa, Canada.

Thompson RC. 1982. "Neptunium: the neglected actinide: A review of the biological and environmental literature." Rad. Res. 90:1-32.

Ticknor KV and YH Cho. 1990. "Interaction of iodide and iodate with granitic fracture-filling minerals." J. Radioanal. Nuclear Chem. 140:75-90.

Tuli JK. 2004. Nuclear Wallet Cards for Radioactive Nuclides. National Nuclear Data Center, Brookhaven National Laboratory, Upton, NY (http://www.nndc.bnl.gov/wallet/wallet4radioactivenuclides.pdf).

Um W, RJ Serne, and KM Krupka. 2004. "Linearity and reversibility of iodide adsorption on sediments from Hanford, Washington under water saturated conditions.” Water Res. 38:2009-2016.

U.S. Department of Energy (DOE). 1997. Hanford Site Background: Part 3, Groundwater Background. DOE/RL-96-61, Rev. 0, U.S. Department of Energy, Richland, WA.

U.S. Environmental Protection Agency (EPA). 1999a. Understanding Variation in Partition Coefficient, $K_{d}$, Values: Volume I. The $K_{d}$ Model, Methods of Measurement, and Application of Chemical Reaction Codes. EPA 402-R-99-004A, prepared by KM Krupka, DI Kaplan, G Whelan, RJ Serne and SV Mattigod at Pacific Northwest National Laboratory for the U.S. EPA, Washington, DC.

U.S. Environmental Protection Agency (EPA). 1999b. Understanding Variation in Partition Coefficient, $K_{d}$, Values: Volume II. Review of Geochemistry and Available $K_{d}$ Values for Cadmium, Cesium, Chromium, Lead, Plutonium, Radon, Strontium, Thorium, Tritium $\left({ }^{3} \mathrm{H}\right)$, and Uranium.

EPA 402-R-99-004B, prepared by KM Krupka, DI Kaplan, SV Mattigod, and RJ Serne at Pacific Northwest National Laboratory for the U.S. EPA, Washington, DC.

U.S. Environmental Protection Agency (EPA). 2004. Understanding Variation in Partition Coefficient, $K_{d}$, Values: Volume III. Review of Geochemistry and Available $K_{d}$ Values for Americium, Arsenic, Curium, Iodine, Neptunium, Radium, and Technetium. EPA 402-R-99-004C, prepared by KM Krupka and RJ Serne at Pacific Northwest National Laboratory for the U.S. EPA, Washington, DC. 
Valocchi AJ. 1985. "Validity of the local equilibrium assumption for modeling sorbing solute transport through homogeneous soils." Water Resour. Res. 21:808-820.

Van der Weijden CH and M Reith. 1982. "Chromium(III)-chromium(VI) interconversions in seawater." Marine Chem. 11:565-572.

van Genuchten MTh. 1981. Non-equilibrium Transport Parameters from Miscible Displacement Experiments. Research Report 119, U.S. Salinity Laboratory, U.S. Department of Agriculture, Washington, DC.

Van Loon L, M Stalmans, A Maes, A Cremers, and M Cogneau. 1986. "Soil-humic acid complexes of technetium: synthesis and characterization." Technetium in the Environments, G Desmet and C Myttenaere (eds.), pp. 143-153. Elsevier Applied Science Publishers, Amsterdam.

Waite TD, JA Davis, TE Payne, GA Waychunas, and N Xu. 1994. "Uranium(VI) adsorption to ferrihydrite: application of a surface complexation model." Geochim. Cosmo. Acta 58(24):5465-5478.

Walters LJ and JW Winchester. 1971. "Neutron activation analysis of sediments for halogens using Szilard-Chalmers reactions." Anal. Chem. 43:1020-1033.

Wan JM, JT Larsen, TK Tokunaga, and ZP Zheng. 2004a. "pH neutralization and zonation in alkalinesaline tank waste plumes.” Environ. Sci. Tech. 38:1321-1329.

Wan JM, TK Tokunaga, JT Larsen, and RJ Serne. 2004b. "Geochemical evolution of highly alkaline and saline tank waste plumes during seepage through vadose zone sediments." Geochim. Cosmo. Acta 68:491-502.

Wang F, J Chen, and W Forsling. 1997. "Modeling sorption of trace metals on natural sediments by surface complexation model." Environ. Sci. Tech. 31:448-453.

Westall JC. 1986. "Reactions at the oxide-solution interface: Chemical and electrostatic models." Geochemical Processes at Mineral Surfaces, pp. 54-78. ACS Symposium Series 323, American Chemical Society, Washington, DC.

Westall JC. 1995. "Modeling of the association of metal ions with heterogeneous environmental sorbents." Scientific Basis for Nuclear Waste Management XVIII, T Murakami and RC Ewing (eds.), pp. 1-12, Vol. 53. Materials Research Society, Pittsburgh, PA.

Westall JC and H Hohl. 1980. "A comparison of electrostatic models for the oxide solution interface." Adv. Colloid Interface Sci. 12:265-294.

Wharton MJ, B Atkins, JM Charnock, FR Livens, RAD Pattrick, and D Collison. 2000. “An X-ray absorption spectroscopy study of the coprecipitation of Tc and Re with mackinawite (FeS)." Appl. Geochem. 15:347-354. 
White AF. 1990. "Heterogeneous electrochemical reactions associated with oxidation of ferrous oxide and silicate surfaces." Reviews in Mineralogy. Mineral-Water Interface Geochemistry, MF Hochella Jr and AF White (eds.), Vol. 23, pp. 467-509. Mineralogical Society of America, Washington, DC.

White AF and MF Hochella, Jr. 1989. "Electron transfer mechanism associated with the surface dissolution and oxidation of magnetite and ilmenite." Water-Rock Interaction WRI-6, DL Miles (ed.), p. 765-768, A. A. Balkema, Rotterdam.

Whitehead DC. 1973. "The sorption of iodide by soils as influenced by equilibrium conditions and soil properties.” J. Sci. Food Agric. 24:547-556.

Whitehead DC. 1974. "The influence of organic matter, chalk, and sesquioxides on the solubility of iodide, elemental iodine, and iodate incubated with soil." J. Soil Sci. 25:461-470.

Whitehead DC. 1984. "The distribution and transformation of iodine in the environment." Environ. Internat. 10:321-339.

Wildung RE, TR Garland, and DA Cataldo. 1977. "Accumulation of technetium by plants." Health Phys. 32:314-317.

Wildung RE, KM McFadden, and TR Garland. 1979. "Technetium sources and behavior in the environment." J. Environ. Quality 8:156-161.

Wildung R, TR Garland, KM McFadden, and CE Cowen. 1986. "Technetium sorption in surface soils." Technetium in the Environment, G Desmet and C Myttenaere (eds.), pp. 115-129, Elsevier Applied Science Publishers, Amsterdam.

Wildung RE, RC Routson, RJ Serne, and TR Garland. 1974. "Pertechnetate, iodide, and methyl iodide retention by surface soils." Pacific Northwest Laboratory Annual Report for 1974 to the USAEC Division of Biomedical and Environmental Research. Part 2. Ecological Sciences, pp. 37-40. BNWL-1950 PT2, Battelle Northwest Laboratories, Richland, WA.

Wildung RE, YA Gorby, KM Krupka, NJ Hess, SW Li, AE Plymale, JP McKinley, and JK Fredrickson. 2000. "Effect of electron donor and solution chemistry on the products of the dissimilatory reduction of technetium by Shewanella putrefaciens." Appl. Environ. Microbio. 66:2452-2460.

Wood MI, R Khaleel, PD Rittmann, SH Finfrock, TH DeLorenzo, and DY Garbrick. 1996. Performance Assessment for the Disposal of Low-Level Waste in the 200 East Area Burial Grounds. WHC-EP-0875, Westinghouse Hanford Company, Richland, WA.

Wood MI, R Khaleel, PD Rittmann, AH Lu, SH Finfrock, RJ Serne, and KJ Cantrell. 1995. Performance Assessment for the Disposal of Low-Level Waste in the 200 West Area Burial Grounds. WHC-EP-0645, Westinghouse Hanford Company, Richland, WA.

Yeh G and VS Tripathi. 1991. "A model for simulating transport of reactive multispecies components: Model development and demonstration." Water Resour. Res. 27:3075-3094. 
Zachara JM, Z Wang, PL Gassman, C Liu, and JG Catalano. 2002a. "Fluorescence Spectroscopic Studies of Uranium-Bearing Vadose Zone Sediments." "Appendix D, Digest of Science and Technology Program Evaluations," in Field Investigation Report for Waste Management Area B-BX-BY. Volume 2, Appendices, pp. D-161 to D-187. RPP-10098, CH2M HILL Hanford Group, Inc., Richland, WA.

Zachara JM, SC Smith, CX Liu, JP McKinley, RJ Serne, and PL Gassman. 2002b. "Sorption of $\mathrm{Cs}^{+}$to micaceous subsurface sediments from the Hanford Site, USA." Geochim. Cosmo. Acta 66:193-211.

Zachara JM, CC Ainsworth, GE Brown, Jr., JG Catalano, JP McKinley, O Qafoku, SC Smith, JE Szecsody, SJ Traina, and JA Warner. 2004. "Chromium speciation and mobility in a high level nuclear waste vadose zone plume." Geochim. Cosmo. Acta 68:13-30.

Zhang J, PO Quay, and DO Wilbur. 1995. "Carbon isotope fractionation during gas-water exchange and dissolution of $\mathrm{CO}_{2}$." Geochim. Cosmo. Acta 59:107-114.

Zhang YQ and WT Frankenberger, Jr. 2000. "Formation of dimethylselenonium compounds in soil." Environ. Sci. Tech. 34:776-783.

Zhang YQ, WT Frankenberger Jr, and JN Moore. 1999. "Effect of soil moisture on dimethylselenide transport and transformation to nonvolatile selenide." Environ. Sci. Tech. 33:3415-3420.

Zhao HT, YJ Deng, JB Harsh, M Flury, and JS Boyle. 2004. "Alteration of kaolinite to cancrinite and sodalite by simulated Hanford tank waste and its impact on cesium retention." Clays Clay Minerals $52: 1-13$.

Zhuang J, M Flury, and Y Jin. 2003. "Colloid-facilitated Cs transport through water-saturated Hanford sediment and Ottawa sand." Environ. Sci. Tech. 37:4905-4911. 


\section{Appendix A}

\section{A Less Conservative Approach to Correcting $K_{d}$ Values for the Presence of Gravel}




\section{Appendix A}

\section{A Less Conservative Approach to Correcting $K_{d}$ Values for the Presence of Gravel}

An alternative approach to correcting $\mathrm{K}_{\mathrm{d}}$ values, which is less conservative than the approach used in the data package, is provided. This approach was developed from a project conducted in conjunction with the ILAW PA, and is described in Kaplan et al. (2000).

The equation used for gravel-corrected $\mathrm{K}_{\mathrm{d}}$ values was:

$$
K d_{g c, g=0}=(1-f) K d_{<2 m m}
$$

where $f$ equaled 0.9. Thus, all the $\mathrm{K}_{\mathrm{d}}$ values in the gravel-dominated sequence were reduced by an order of magnitude $(1-\mathrm{f}=1-0.9=0.1)$. An alternative correction would be:

$$
K d_{g c, g=x}=(1-f) K d_{<2 m m}+(f) K d_{>2 m m} .
$$

Equation A.1 underestimated actual $\mathrm{K}_{\text {dtotal }}$ by $28 \%$ to $47 \%$, whereas Equation A.2 slightly overestimated $\mathrm{K}_{\text {dtotal }}$ by $3 \%$ to $5 \%$ (Kaplan et al. 2000). Equation A.1 is conservative and Equation 2.2 is not, although the difference between $\mathrm{K}_{\mathrm{dtotal}}$ and $\mathrm{K}_{\mathrm{dgc}, \mathrm{g}=\mathrm{x}}$ is not significant $(\mathrm{P}<0.05)$. Equation A.1 becomes less and less accurate, i.e., the degree to which it underestimates $\mathrm{K}_{\text {dtotal }}$ increases, as the percent of gravel $(f)$ increases. At $f=0.9, \mathrm{~K}_{\mathrm{dgc}, \mathrm{g}=0}$ will greatly underestimate the actual $\mathrm{K}_{\mathrm{dtotal}}$.

An attempt was made to apply Equation A.2 to the gravel corrections. We have laboratory data on strontium and cesium for $\mathrm{K}_{\mathrm{d}>2 \mathrm{~mm}}$, i.e., 2 of the 26 radionuclides for which $\mathrm{K}_{\mathrm{d}}$ data are needed for the data package. The ratio of $\mathrm{K}_{\mathrm{d}>2 \mathrm{~mm}} / \mathrm{K}_{\mathrm{d}<2 \mathrm{~mm}}$ for strontium and cesium were 0.23 and 0.42 , respectively.

Assuming all radionuclides have a $\mathrm{K}_{\mathrm{d}>2 \mathrm{~mm}} / \mathrm{K}_{\mathrm{d}<2 \mathrm{~mm}}$ of 0.23 , we can rewrite Equation A.2 as:

$$
K d_{g c, g=x}=(1-f) K d_{<2 m m}+(f) 0.23 K d_{<2 m m} .
$$

and then by setting $f=0.9$, this simplifies to:

$$
K d_{g c, g=x}=0.31 K d_{<2 m m} .
$$

Thus, gravel-corrected $\mathrm{K}_{\mathrm{d}}$ values based on Equation A.4 will be $210 \%$ greater than those based on Equation A.1. Equation A.4 is likely to provide a more accurate estimate than Equation A.1, especially at the high-gravel concentrations needed for the PA. Perhaps more importantly, more uncertainty is associated with the approach presented in A.4 due to the lack of $\mathrm{K}_{\mathrm{d}<2 \mathrm{~mm}}$ for each radionuclide (Kaplan et al. 2000). 


\section{Reference}

Kaplan DI, IV Kutnyakov, AP Gamerdinger, RJ Serne, and KE Parker. 2000. "Gravel corrected $\mathrm{K}_{\mathrm{d}}$ values." Ground Water 38(6):851-857. 


\section{Appendix B}

\section{Discussion on Double Layer and Film Thickness}




\section{Appendix B}

\section{Discussion on Double Layer and Film Thickness}

The double layer thickness was estimated from the Debye-Huckel Parameter (K) (Hiemenz and Rajagopalan 1997):

$$
\mathrm{K}=\left[\left(\frac{1000 e^{2} N_{A}}{\varepsilon k_{B} T}\right) \sum_{i} z_{i}^{2} M_{i}\right]^{1 / 2}
$$

where $\mathrm{K}^{-1}(\mathrm{~m})$ is sometimes used to estimate the double layer thickness, $e$ is the electric charge (or charge of an electron, units $=\mathrm{C}), N_{\mathrm{A}}$ is Avogadro's number, $\varepsilon$ is fluid permittivity $\left(\mathrm{C} \mathrm{V}^{-1} \mathrm{~m}^{-1}\right), \mathrm{k}_{\mathrm{B}}$ is Boltzmann's constant $\left(\mathrm{J} \mathrm{K}^{-1}\right), z$ is the valence of the electrolyte, and $M$ is the electrolyte concentration $(\mathrm{M})$.

Assuming $\mathrm{Ca}^{2+}$ and $\mathrm{SO}_{4}{ }^{2-}$ are the dominant ions at an ionic strength of $10 \mathrm{mM}$, the double layer thickness based on Equation B.1 is $1.5 \times 10^{-9} \mathrm{~m}$.

The film thickness was calculated with the following equation taken from Hillel (1980):

$$
\lambda=\frac{\theta}{\rho_{b} A_{s s}}
$$

where $\lambda$ is the film thickness ( $\mathrm{cm}), \theta$ is the volumetric water content, $A_{s s}$ is the specific surface area $\left(\mathrm{cm}^{2} / \mathrm{g}\right)$, and $\rho_{\mathrm{b}}$ is the bulk density $\left(\mathrm{g} / \mathrm{cm}^{3}\right)$. Using $\theta=0.6, \rho_{\mathrm{b}}=1.25 \mathrm{~g} / \mathrm{cm}^{3}$, and $A_{s s}$ of $2000 \mathrm{~cm}^{2} / \mathrm{g}$ in Equation B.2, the film thickness $(\lambda)=2.4 \mu \mathrm{m}$.

\section{References}

Hillel D. 1980. Fundamentals of Soil Physics. Academic Press, New York.

Hiemenz PC and R Rajagopalan. 1997. Principles of Colloid and Surface Chemistry. $3^{\text {rd }}$ Edition, Marcel Dekker, Inc., New York. 


\section{Appendix C}

\section{Information Requested for Near-Field Geochemical Transport Modeling}




\section{Appendix C}

\section{Information Requested for Near-Field Geochemical Transport Modeling}

Reactive transport modeling of the vitrified waste leaching and the near field is being performed using the computer code STORM that is described in the Waste Form Leaching Data Package (McGrail et al. 1999). The STORM code requires that the user provide the chemical formulas for the reactions needed to form the solid minerals that constitute the sediments and engineered barriers surrounding the glass waste forms and any secondary precipitates that form during the weathering process as water percolates into the IDF and interacts with the glass forms. Our Geochemical Data Package document will provide guidance and input to the STORM code. The mineralogy of the Hanford sand sediments that might be used for backfill and the native Hanford formation sands and gravels have been partially characterized at the IDF site (see Horton et al. [2003]). Further, some quantitative mineralogy of Hanford formation sediments taken from outcrops and from the sides of other solid waste disposal facilities in the 200 East and 200 West Areas has been reported. The data on pages 5 through 28 in Serne et al. (1993) list detailed mineralogical, geochemical, hydrologic, and physical characterization information for four sediments. Other quantitative mineralogy characterization of sediments underlying single-shell tank farms is found in Serne et al. (2002) and Lindenmeier et al. (2003). All this mineralogical information can be used as input to STORM.

In fiscal year (FY) 2000, about 10 of the 21 samples from the ILAW borehole (299-E17-21) drilled in FY 1998 were characterized for quantitative mineralogy using the same techniques discussed in Serne et al. (1993). The 21 samples were used to obtain site-specific $K_{d}$ values, cation exchange capacities, particle sizes, and hydrologic parameters in FY 1998-1999. These data have been documented in topical reports (Kaplan et al. 1998; Reidel et al. 1998) and companion 2001 data packages (Khaleel 1999; Reidel and Horton 1999).

Mineralogy data needed for the STORM code reactive transport calculations for cement and concrete are available in Criscenti and Serne (1990), Criscenti et al. (1996), and Krupka and Serne (1996) and references cited therein. Hydrologic and physical properties of cement and concrete are discussed in Meyer and Serne (1999) and references cited therein. No actual data are available for cement solidified secondary waste forms, which will be co-disposed in the IDF, at this time.

It is unlikely that the 2005 IDF PA predictions will attempt to model all chemical dissolution/ precipitation reactions for the backfill sediments, natural sediments, or solidified secondary waste forms that will constitute the IDF at closure. One practical reason for this omission is that the 2001 ILAW PA predicted wide margins of safety even using simple (and conservative) conceptual models for the very near-field interactions of the ILAW waste form with surrounding backfill and natural vadose-zone sediments. We expect the reaction products that precipitate from weathering of the various waste forms to be placed in the IDF and the surrounding backfill and natural vadose-zone sediments will sequester contaminants to a greater extent than the currently used simplified conceptual models allow. 


\section{References}

Criscenti LJ and R J Serne. 1990. "Thermodynamic modeling of cement/groundwater interactions as a tool for long-term performance assessment." In Scientific Basis for Nuclear Waste Management XIII, VM Oversby and PW Brown (eds.), Vol. 176, pg. 81-90, Materials Research Society, Pittsburgh, PA.

Criscenti LJ, RJ Serne, KM Krupka, and MI Wood. 1996. Predictive Calculations to Assess the LongTerm Effect of Cementitious Materials on the pH and Solubility of Uranium(VI) in a Shallow Land Disposal Environment. PNNL-11182, Pacific Northwest Laboratory, Richland, WA.

Horton DG, HT Schaef, RJ Serne, CF Brown, MM Valenta, TS Vickerman, IV Kutnyakov, SR Baum, KN Geiszler, and KE Parker. 2003. Geochemistry of Samples from Borehole C3177(299-E24-21). PNNL-14289, Pacific Northwest National Laboratory, Richland, WA.

Kaplan DI, KE Parker, and IV Kutnyakov. 1998. Radionuclide Distribution Coefficients for Sediments Collected from Borehole 299-E17-21: Final Report for Subtask 1a. PNNL-11996, Pacific Northwest National Laboratory, Richland, WA.

Khaleel R. 1999. Far-Field Hydrology Data Package for Immobilized Low-Activity Tank Waste Performance Assessment. HNF-4769, Rev. 1, Fluor Daniel Northwest, Inc., Richland, WA.

Krupka KM and RJ Serne. 1996. Performance Assessment of Low-Level Radioactive Waste Disposal Facilities: Effects on Radionuclide Concentrations by Cement/Ground-Water Interactions.

NUREG/CR-6377, U.S. Nuclear Regulatory Commission, Washington, DC.

Lindenmeier CW, RJ Serne, BN Bjornstad, GW Gee, HT Schaef, DC Lanigan, MJ Lindberg, RE Clayton, VL Legore, IV Kutnyakov, SR Baum, KN Geiszler, CF Brown, MM Valenta, TS Vickerman, and LJ Royack. 2003. Characterization of Vadose Zone Sediment: RCRA Borehole 299-E33-338 Located Near the B-BX-BY Waste Management Area . PNNL-14121, Pacific Northwest National Laboratory, Richland, WA.

McGrail BP, DH Bacon, JP Icenhower, WL Ebert, P Martin, HT Schaef, and EA Rodriguez. 1999. Waste Form Release Data Package for the 2001 Immobilized Low-Activity Waste Performance Assessment. PNNL-13043, Pacific Northwest National Laboratory, Richland, WA.

Meyer PD and RJ Serne. 1999. Near-Field Hydrology Data Package for the Immobilized Low-Activity Waste 2001 Performance Assessment. PNNL-13035, Pacific Northwest National Laboratory, Richland, WA.

Reidel SP and DG Horton. 1999. Geologic Data Package for 2001 Immobilized Low-Activity Waste Performance Assessment. PNNL-12257, Rev. 1, Pacific Northwest National Laboratory, Richland, WA.

Reidel SP, KD Reynolds, and DG Horton. 1998. Immobilized Low-Activity Waste Site Borehole 299E17-21. PNNL-11957, Pacific Northwest National Laboratory, Richland, WA. 
Serne R.J, JL Conca, VL LeGore, KJ Cantrell, CW Lindenmeier, JA Campbell, JE Amonette, and MI Wood. 1993. Solid-Waste Leach Characteristics and Contaminant-Sediment Interactions.

Volume 1: Batch Leach and Adsorption Tests and Sediment Characterization. PNL-8889, Vol. 1. Pacific Northwest Laboratory, Richland, WA.

Serne RJ, HT Schaef, BN Bjornstad, BA Williams, DC Lanigan, DG Horton, RE Clayton, VL LeGore, MJ O'Hara, CF Brown, KE Parker, IV Kutnyakov, JN Serne, AV Mitroshkov, GV Last, SC Smith, CW Lindenmeier, JM Zachara, and DB Burke. 2002. Characterization of Uncontaminated Vadose Zone Sediment from the Hanford Reservation - RCRA Borehole Core Samples and Composite Samples.

PNNL-13757-1, Pacific Northwest National Laboratory, Richland, WA. 


\section{Distribution}

No. of

$\underline{\text { Copies }}$

\section{OFFSITE}

Harry Babad

2540 Cordoba Court

Richland, WA 99352-1609

Patrick V. Brady

Geochemistry Department, 6118

Sandia National Laboratories

P.O. Box 5800

Albuquerque, NM 87185-0750

Charles R. Bryan

Sandia National Laboratories

4100 National Parks Highway

Carlsbad, NM 88220

Jon Chorover

Associate Professor - Environmental

Chemistry

Department of Soil, Water, and

Environmental Science

Shantz 429, Building \#38

University of Arizona

Tucson, AZ 85721-0038

Dave G. Coles

Coles Environmental Consulting

750 South Rosemont Road

West Linn, OR 97068

Mark Conrad

Department of Earth and Planetary Sciences

University of California, Berkeley

Berkeley, CA 94720
No. of

$\underline{\text { Copies }}$

James A. Davis

U.S. Geological Survey

MS 465

345 Middlefield Road

Menlo Park, CA 94025

Donald J. DePaolo

Geology \& Geophysics Dept. MC4767

University of California

Berkeley, CA 94720-4767

Dirk A. Dunning

Oregon Office of Energy

625 Mariona Street, N.E.

Salem, OR 97301-3742

Markus Flury

Department of Crop and Soil Sciences

Washington State University

Pullman, WA 99164

Amy P. Gamerdinger

2122 E. Hawthorne

Tucson, AZ 85719

Jim Harsh

Department of Crop \& Soil Sciences

Washington State University

Johnson Hall, Room 249

Pullman, WA 99164-6420

Cliff Johnston

Soil Chemistry and Mineralogy

1150 Lily Hall

Purdue University

West Lafayette, IN 47907-1150 
No. of

Copies

Daniel I. Kaplan

Westinghouse Savannah River Company

Building 774-43A, Room 215

Aiken, SC 29808

Melaine A. Mayes

Environmental Sciences Division

Oak Ridge National Laboratory

P.O. Box 2008

Oak Ridge, TN 37831-6038

Heino Nitsche

Director, Center for Advanced

...Environmental and Nuclear Studies

Lawrence Berkeley National Laboratory

1 Cyclotron Road

MS 70A-1150

Berkeley, CA 94720

Phil Reed

U.S. Nuclear Regulatory Commission

Office of Nuclear Regulatory Research

Division of Systems Analysis and

Regulatory Effectiveness

Radiation Protection, Env. Risk and Waste

Management Branch

MS T9-F31

Washington, DC 20555-0001

Al Robinson

68705, E 715 PRNE

Richland, WA 99352

Doug Sherwood

Rivers Edge Environmental

1616 Riverside Drive

West Richland, WA 99353

David K. Shuh

Lawrence Berkeley National Laboratory

1 Cyclotron Road, MS 70A-1150

Berkeley, CA 94720
No. of

Copies

James "Buck" Sisson

Idaho National Engineering and

Environmental Laboratory

P.O. Box 1625, MS 2107

Idaho Falls, ID 83415-2107

T. T. Chuck Vandergraaf

P.O. Box 857

Pinawa, Manitoba R0E 1L0

Canada

Jiamin Wan

Lawrence Berkeley National Laboratory

1 Cyclotron Road, MS 70-0127A

Berkeley, CA 94720

Ronald G. Wilhelm

Office of Radiation and Indoor Air

401 M Street, S.W.

Mail Code 6603J

Washington, D.C. 20460

W. Alexander Williams

U.S. Department of Energy

Office of Environmental Restoration

EM-33

19901 Germantown Road

Germantown, MD 20874-1290

\section{ONSITE}

4 DOE Office of River Protection

$\begin{array}{ll}\text { P. E. LaMont } & \text { H6-60 } \\ \text { R. W. Lober } & \text { H6-60 } \\ \text { S. A. Wiegman } & \text { H6-60 } \\ \text { R. B. Yasek } & \text { H6-60 }\end{array}$


No. of

Copies

8 DOE Richland Operations Office

B. L. Foley

A6-38

J. P. Hanson

R. D. Hildebrand

K. A. Kapsi

J. G. Morse

K. M. Thompson

DOE Public Reading Room (2)

A5-13

A6-38

A5-13

A6-38

A6-38

H2-53
14 CH2M HILL Hanford Group, Inc.

F. J. Anderson

K. Colosi

M. P. Connelly

T. E. Jones

A. J. Knepp

S. Lambert

F. M. Mann (4)

W. J. McMahon

D. A. Myers

G. Parsons

T. L. Sams

3 Environmental Protection Agency

N. Ceto

D. A. Faulk

M. L. Goldstein

\section{Fluor Federal Services}

R. Khaleel

R. J. Puigh

\section{Fluor Hanford, Inc.}

T. W. Fogwell

E6-17

E6-17

E6-35
No. of

Copies

5 Washington State Department of Ecology

S. Dahl-Crumpler

H0-57

J. A. Caggiano H0-57

F. Hodges H0-57

A. D. Huckaby H0-57

J. Yokel H0-57

45 Pacific Northwest National Laboratory

D. H. Bacon K9-33

C. F. Brown P7-22

R. W. Bryce E6-35

K. J. Cantrell K6-81

W. J. Deutsch K6-81

M. J. Fayer K9-33

M. D. Freshley K9-33

D. G. Horton K6-81

J. P. Icenhour K6-81

C. T. Kincaid E6-35

K. M. Krupka (12) K6-81

G. V. Last K6-81

M. J. Lindberg P7-22

C. W. Lindenmeier P7-22

C. A. LoPresti K9-42

W. J. Martin K6-81

S. V. Mattigod K6-81

B. P. McGrail (2) K6-81

P. D. Meyer BPO

E. M. Pierce K6-81

S. P. Reidel K6-81

R. G. Riley K6-81

R. J. Serne (10) P7-22

W. Um P7-22

Information Release (2) K1-06

B. H. Ford

E6-35

V. G. Johnson E6-35

M. I. Wood H8-44 